
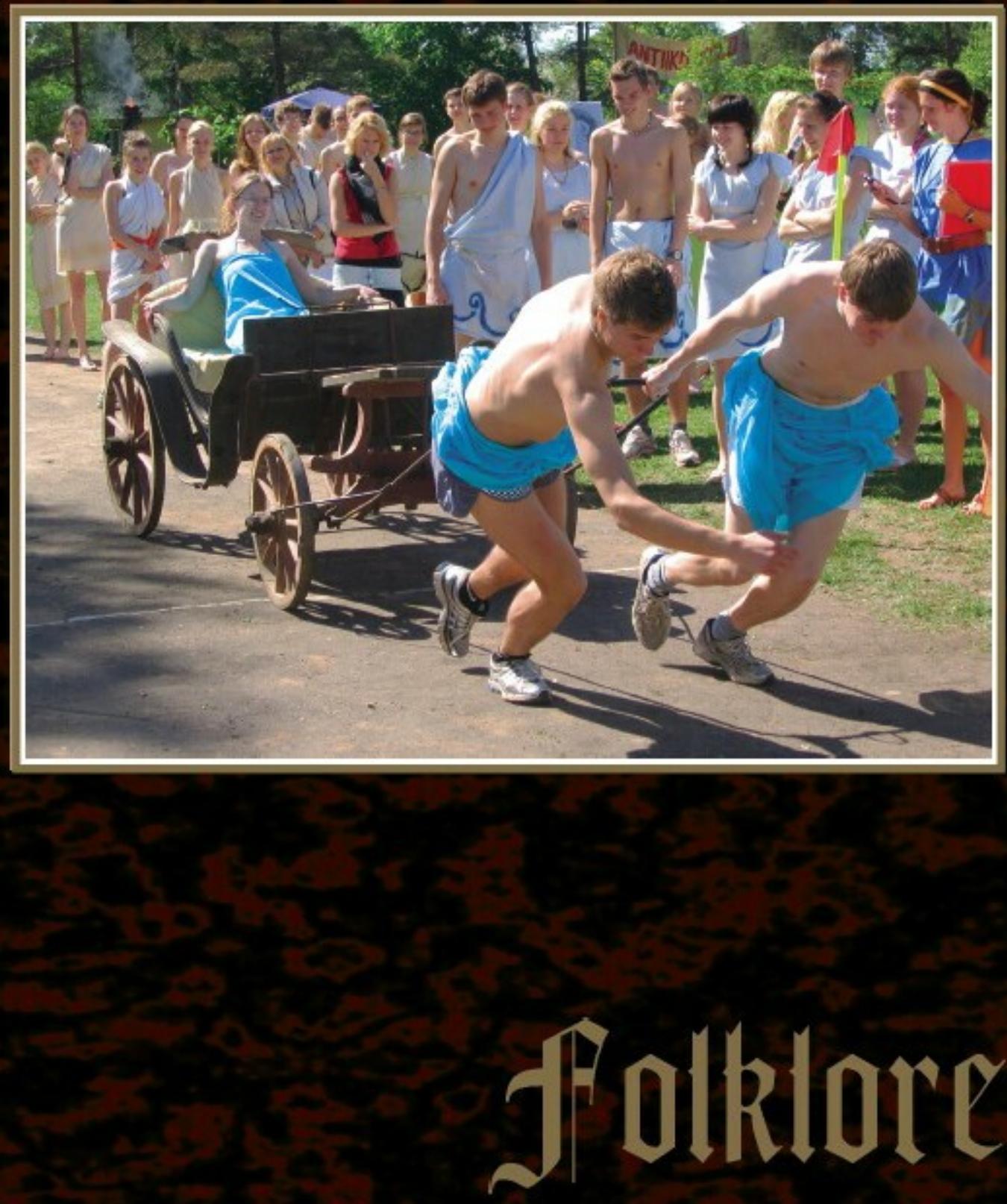

Electronic Journal of Folklore 54 
Folk Belief and Media Group of the Estonian Literary Museum

Estonian Institute of Folklore

\section{Folklore}

Electronic Journal of Folklore

Vol. 54

Edited by Mare Kõiva \& Andres Kuperjanov Guest editors: Piret Voolaid \& Kalle Voolaid

Tartu 2013 
Editor in chief

Co-editor

Guest editors

Copy editor

News and reviews

Design

Layout
Mare Kõiva

Andres Kuperjanov

Piret Voolaid \& Kalle Voolaid

Tiina Mällo

Piret Voolaid

Andres Kuperjanov

Diana Kahre

Editorial board 2008-2014: Dan Ben-Amos (University of Pennsylvania, USA), Larisa Fialkova (University of Haifa, Israel), Diane Goldstein (Memorial University of Newfoundland, Canada), Terry Gunnell (University of Iceland), Jawaharlal Handoo (University of Mysore, India), Frank Korom (Boston University, USA), Monika Kropej (Institute of Slovenian Ethnology), Kristin Kuutma (University of Tartu, Estonia), Aado Lintrop (Estonian Literary Museum), Wolfgang Mieder (University of Vermont, USA), Irina Sedakova (Russian Academy of Sciences).

Electronic version is supported by Estonian Science Foundation (grant no. 8137).

Printed version is supported by state programme projects EKKM09-168 and EKKM09-170.

Indexed in EBSCO Publishing Humanities International Complete, Thomson Reuters Arts \& Humanities Citation Index, MLA International Bibliography, Ulrich's Periodicals Directory, Internationale Volkskundliche Bibliographie / International Folklore Bibliography / Bibliographie Internationale d'Ethnologie), DOAJ, C.E.E.O.L., ERIH (B)

\section{Editorial address:}

Folklore: Electronic Journal of Folklore

Vanemuise 42-235

51003 Tartu

Estonia

phone: $\quad+3727377740$

fax: $\quad+3727377706$

e-mail: folklore@folklore.ee

home page: http://www.folklore.ee/folklore

All rights reserved

(C) Folk Belief and Media Group of the Estonian Literary Museum

EKM Teaduskirjastus/ELM Scholarly Press

Estonian Institute of Folklore

Authors

Design Andres Kuperjanov

ISSN 1406-0957

doi:10.7592/FEJF2013.54 


\section{CONTENTS}

Introduction: Sport Culture, Games and Folk Dance 7

Piret Voolaid, Kalle Voolaid

We Believe! Online Representations of the Olympic Winner as a Mythic Hero

Piret Voolaid, Liisi Laineste

Violence and Roughness in Traditional Games and Sports:

The Case of Folk Football (England and Scotland)

Laurent Sébastien Fournier

Betel Nut, Magic and Baseball: A Case Study of Puyuma Tribe in Taiwan

Junwei Yu

Estonian Folk Dance: Terms and Concepts in Theory and Practice Sille Kapper

Motivational Underpinnings of Estonian Folk Dance Practices among the Estonian Diaspora over Time

Eha Rüütel, Iivi Zajedova, Angela Arraste

Traditional Children's Games of Bihar Sarita Sahay

\section{Discussions}

School Olympics in Estonia: New Chance of Life for Traditional Sports

and Games? Kalle Voolaid

The Traditions of Fisticuffs in the North-West of Russia from the

Early Middle Ages to the Modern Era. Dmitry Belyukov 


\section{NEWS IN BRIEF}

Doctoral Thesis on the Spatial Semantics of Locative Cases in the Komi Language

Transformations. Galina Nekrasova

Estonian Folklorists' 8th Winter Conference. Inge Annom

President's Folklore Award and the Year 2012 at the Estonian Folklore Archives.

Astrid Tuisk

Two Heads are Better than One: Phraseology and Paremiology in Dictionaries and in Everyday Use. Saša Babič

International Interdisciplinary Conference Still Postsocialism? Cultural Memory and Social Transformations. Aimar Ventsel

Book REVIEW

About Fairy Tale Genre on the Example of the Irish Narrative Tradition.

Kärri Toomeos-Orglaan 


\section{INTRODUCTION: SPORT CULTURE, GAMES AND FOLK DANCE}

\section{Piret Voolaid, Kalle Voolaid}

The current issue is published in cooperation between the Department of Folkloristics of the Estonian Literary Museum and the Estonian Sports Museum. This is certainly not a coincidence that it happens exactly in 2013 - the year when the Estonian Sports Museum celebrates its 50th anniversary. As the aim of the Estonian Sports Museum is to foster and preserve the traditions of Estonian sport, the special issue of our journal is dedicated to sport and physical movement culture, games and folk dance. The writings deal with different problems of sport and traditional games phenomena in heritage (fan movements and traditions, different outputs of traditional sport culture, sports and games in new media, sport folklore and semiotics, etc.).

Here we should bear in mind that the broad definition of the term 'sports' considers, along with the development of physical shape and mental well-being, also facilitation of social interactions as a function of sport, which enables us to regard expressions of sports and sports-related activities (especially folkloric) as one of the forms of culture.

The issue begins with an article on an extremely topical theme - doping in sport. Piret Voolaid and Liisi Laineste (Estonian Literary Museum) analyse the doping scandal that broke out in April 2011 and concerned the esteemed Estonian cross-country skier and Olympic gold medal winner, Andrus Veerpalu. The doping case was a collective shock that attracted the attention of the media immediately and channelled into various stories, for instance, the newslore and contemporary sports folklore that was based on the fiery public discussion. The article provides a contribution to the evolution of an athlete as a mythic national hero on the Internet.

The first article is followed by two treatises on ballgames in traditional folk culture. We all know that the relationship between sport (football) and violence is a hot topic in contemporary sociology and anthropology. Laurent Sébastien Fournier (University of Nantes) suggests that the example of folk football in England and Scotland enables us to better understand the relationship between sport and violence. The violence that regularly appears in modern sport and hooliganism can be interpreted as an unconscious restoration of very old dual 
cultural schemes, connected in a broad psychological perspective to the youth's universal taste for pride and parade.

Junwei Yu (Department of Physical Education, National Taiwan University of Physical Education and Sport) discusses in his article connections between baseball and magic in Taiwan, claiming that the Puyuma tribe in Taiwan indubitably applies its folk religion to baseball, and produces a unique sports phenomenon. This article examines the extent to which betel nuts were used as a vehicle for the expression of human relationships with the supernatural in baseball.

The next two articles in the issue are dedicated to folk dance. In the first one Sille Kapper (Institute of Fine Arts, Tallinn University) offers an interesting overview of the changes in the concept of 'folk dance' in Estonia, starting from the end of the 19th century until today. The author finds that her borderline position between the roles of a dance researcher and a dancer and folk dance teacher in practice makes it possible to switch between different discourses and find their intersections.

Eha Rüütel, Iivi Zajedova and Angela Arraste (Institute of Fine Arts, Tallinn University) in turn analyse interviews with Estonians living abroad and try to find answers to two research questions: 1) What incentives have guided Estonians' folk dance activity in historical perspective from World War II until today? 2) What qualities originating in Estonian folk dance have motivated people to carry on Estonian folk dance practices?

The section of research is completed by an article on playing culture. Sarita Sahay's (School of Political and Social Inquiry, Monash University, Melbourne) article aims at exploring how children, particularly in rural areas of Bihar, an economically poor but culturally rich state of India, enjoy their leisure with limited resources available to them. The author gives an overview of some popular games played by boys and girls in Bihar, which were selected in view of their popularity.

In addition to research articles, the special issue offers to the readers two writings in the discussion section. Kalle Voolaid (Estonian Sports Museum) introduces an interesting trend in the development of the School Olympic Games in Estonia - the use of traditional sports and games in the School Olympics programme. With the help of concrete examples the article gives an overview of a variety of colourful ideas used in Estonian schools, starting with popular traditional sports and ending with newborn disciplines.

Dmitry Belyukov (Faculty of Humanities and Socio-Economic Disciplines, Velikiye Luki State Academy of Physical Education and Sports) discusses the traditions of fisticuffs in the north-west of Russia from the Early Middle Ages to the modern era. The author explains that fisticuffs was one of the forms of physical training in the national culture of the East Slavs, which continued up to the second half of the 19th century, until it was banned by the authorities. 


\title{
WE BELIEVE! ONLINE REPRESENTATIONS OF THE OLYMPIC WINNER AS A MYTHIC HERO
}

\author{
Piret Voolaid, Liisi Laineste
}

\begin{abstract}
This article ${ }^{1}$ is a study of the doping scandal that broke out in April 2011 and concerned the esteemed Estonian sportsman and Olympic gold medal winner, Andrus Veerpalu. The current analysis is based on the material collected from the Estonian online media throughout two years, from April 2011 to March 2013, during which Andrus Veerpalu's court case was actively followed by the Estonian sports circles and laymen alike. We will analyse how the image of Andrus Veerpalu as a national hero (almost as a demigod) is constructed on the Internet and how it relates to analogous stories about athletes from earlier times (e.g., to folk stories about Georg Lurich).

In the current case, the main reason why the majority of the nation supported Andrus Veerpalu was because they believed in him. This pervading thread emerged right after the news spread, and was present in various contexts: the online comments of the articles that dealt with the scandal, Facebook community posts in the group entitled "We believe in Andrus Veerpalu" ("Usume Andrus Veerpalu"), which was created to show solidarity with the sportsman, etc. All this indicated the high status of the athlete and laid a foundation for a sincere and positive discourse. This was in opposition to the negative discourse of irony, which questioned the honesty of the athlete and foregrounded subversive emotions like indifference and superiority towards the topic. The analysis will address the emergence of the Olympic hero as a national myth, and point at various narratives that deal with the scandal through the present-day genres of urban legends, conspiracy stories, and Internet humour.
\end{abstract}

Keywords: conspiracy stories, fan culture, folklore about doping cases, mythic hero, national identity, sports folklore, stereotypes

\section{INTRODUCTION}

On February 23, 2011, the famous Estonian cross country skier Andrus Veerpalu, who had twice won the world championship as well as collected two gold medals at the Olympic Games, announced the termination of his career as a sportsman. This unexpected news was seen under a different light when one and a half months later, on April 7, a doping scandal broke out after the Estonian Ski Association had organised a press conference to announce that Veerpalu 
had tested positive for growth hormone in a doping test that he had taken about two months earlier. Regardless of his plea for innocence, the International Ski Federation decided on August 23, 2011, to punish him by suspending him from competition for three years. But as the long court case drew to a close, Veerpalu was acquitted on March 25, 2013. The case was dismissed and his competition ban was withdrawn. The main argument of his defence - that the doping tests were not sensitive enough to distinguish between forbidden substances and the level of natural growth hormones increased by excessive exercising - had been successful.

Throughout these two years the media and the general public showed heightened interest in everything connected with Andrus Veerpalu in particular and doping issues in professional sports in general. The Olympic winner denied that he had used any forbidden substances, either during competitions or at other times, although he admitted at a press conference that he had found out about the positive doping test results already before announcing his decision to end his career. The active concern in the topic was first fostered by the professional media and further amplified by the social resonance visible in the persistent interest of different online community groups. This was evident in news texts, innumerable comments that followed each of those, public discussions and events, and the creation of social media communities for Veerpalu's fans and those who believed in his innocence. It is important to point out that social networks have become a very important channel of information in the presentday world, but not only that - social networks do not only spread information but also shape and restructure it, making it more difficult to separate the communicator from the content of the message. New knowledge communicated across the community and even further is actively produced. This, in addition to comments in online news portals (the continuous creation and resonance of information as well as the emotional aspect of the communication), has proven to provide ideal data for the folklorist. Internet material comes in different genres, for example, narratives, rumours of conspiracy theories, jokes and anecdotes, stories containing (ethnic) stereotypes, etc. It is interesting to note that in the public discussion of the current case, believing in the sportsman became one of the central topics. In the highly emotional public dispute, people were split into two camps that stood in sharp opposition. On the one hand, there were those who represented the serious and earnest discourse, either supporting Veerpalu's innocence or, to a lesser extent, advocating against it; on the other hand, the sceptics voiced the ironic discourse, mocking the ones who believed, but also criticising the role of the media in the scandal. The purpose of this article is to describe the attitudes and stereotypes displayed in Veerpalu's doping case and list their potential interpretations in the broader socio-cultural context. 
The material for the study was collected in the course of two years. The data includes the most relevant news texts published on the online news portal Delfi (www.delfi.ee), posts and commentaries from the same online environment, and posts from the Facebook fan site "We believe in Andrus Veerpalu"2.

\section{THEORETICAL BACKGROUND}

\subsection{Andrus Veerpalu's doping case as a source of newslore}

Russell Frank, American researcher with an academic background in journalism, has coined the term "newslore" to denote folklore that stems from the knowledge disseminated by daily news and provides a commentary on it (Frank 2011). Newslore can be displayed in various genres of folklore: jokes (including disaster humour), sayings, rumours and conspiracy theories, digitally manipulated photos, news parodies, printed inserts, unofficial circulars, parodies of songs and poetry, commercial and political advertising, comics and animations, etc. Also the stories, ideas and beliefs that were created and spread during Andrus Veerpalu's lengthy doping scandal can be defined as newslore because they mostly relied on daily news. Apart from the narratives themselves, the reactions to the narratives (in the form of online comments) contain folkloric elements. The whole dataset, i.e., the newslore narratives and their comments, form an excellent instance of sports folklore.

Sports folklore is a genre that shares an overarching topic - sports (cf. also Voolaid 2003: 197). The focus of sports folklore is the sportsman, the main actor in the field. The carriers of tradition can be divided into three main categories: (1) sportsmen and people closely connected to the area (sports pedagogues: coaches, teachers of physical education, specialists in training methods); other people dealing with sports (officials, sports journalists, doctors, etc.); (2) people interested in sports (fans, amateur sportsmen, audience members at sporting events, so-called armchair sportsmen or people watching sports programmes at home); (3) laymen, people usually unacquainted with the field and the nuances of the work and private lives of sportsmen and their coaches. It is not possible, of course, to define these categories fully and exhaustively. For example, someone extremely knowledgeable in the folklore of a certain area of sports may be ignorant of the slang and traditions of another. There is, however, a common set of sports narratives that are known equally well by fans and laymen, and this layer of folklore is very often related to events or phenomena in sports that have received the biggest public attention. Any popular sports events and large scandals may eventually involve the third group, laymen. The case that we are 
analysing in this article captured wide public attention, and hence it is not surprising that the event resonated not only in the sports-related circles (groups 1 and 2), but also in the group least familiar with sports (group 3). The latter got their information from the media or by word of mouth from their friends or acquaintances. The laymen made their decisions regarding the scandal relying on secondary sources. The attitudes of the third group are highly visible in the analysed Internet comments. It is exactly them who loudly express their evaluations and monochrome attitudes towards sports in the form of sports folklore. The emotions shape the stories: the commentators dream of a medal, Olympic or other; they talk about their hopes vested in the heroes, they crave for celebrities, and they show their excitement about hearing and spreading the rumours, scandals and intrigues surrounding these stories.

The leading sportsmen and athletes are well-established targets of public attention, who have stepped or been dragged into the spotlight. Folklore about such matters enables the researcher to gain an insight into the prevalent reactions and attitudes in a particular case. When the leading sportsman, the hero, faces misfortune instead of success, consecutive narratives display evaluations and stereotypical points of view.

\subsection{Olympic winner as a national hero}

There are plenty of examples in sports history concerning the fortifying effect that the success of a famous athlete can have on the national spirit and community. The classical examples of Estonian athletes from the late 19th and early 20th centuries stress the heroic quality of the weight lifters and wrestlers who were active at that time. These narratives in turn support the identity of a nation. For example, the heroic stories and tales about the first Estonian wrestler Georg Lurich are still known and told among people. Kalle Voolaid, who has studied the question of truth and imagination in the narratives about the said wrestler, has maintained, grounding his claims on the analysis of about a hundred folk stories, that most of them did not really take place (2001: 186). Instead, some known motives from old heroic stories have been borrowed and integrated into these narratives.

Longstanding traditions and public attention in the media support the emergence of national sports. In Estonia, one of the national sports is certainly cross country skiing, which is sustained by the keen interest of the audience and amateurs; its reputation is also backed up by outstanding results in big competitions. It is of no less importance that the climatic conditions favour the field as well. The high international ranking of Estonian cross country skiers has 
further perpetuated the important role of the sport for the Estonian identity. Andrus Veerpalu, who is a positive hero par excellence, in terms of character traits and behaviour, has acquired the status through hard work, effort and considerable talent. Veerpalu has been known to the Estonian audience as an honest, hard-working man, a "true Estonian", and is equally praised for being an exemplary head of the family, raising five children, most of whom do cross-country skiing on a competitive level. The image of an idol was quick to emerge from this; the difficult journey and misfortunes of a strong national hero were a recurrent motive in the stories that circulated at that time. All these aspects were brought to attention by different experts and laymen during the scandal that followed Veerpalu's positive results in the doping test. For example, a lecturer of public relations at the University of Tartu, Aune Past, gave an interview for the biggest daily newspaper Postimees (The Courier) (Smutov 2011), explaining the strong support and extraordinary affection of the people by stressing how the audience wanted to identify with the hero. At the same time, the scandal tore into the open a number of contradictory issues and questions, asking if Veerpalu was telling the truth or lying, and whether he was closer to a hero or an anti-hero (ibid.).

From a folklorist's point of view, the article written by psychologist Voldemar Kolga (2011) is thought-provoking as well. The author explains the strong public support by using the theory of Joseph Campbell who in the 1940s coined the term monomyth (Campbell 2004: 28). According to his concept, a hero is a person who leaves his everyday life in order to undertake a journey into the unknown, into a different world, where he accepts challenges, overcomes his fears, and, as a result, brings back trophies or awards that he can then share with his people, his community (Kolga 2011).

In a similar vein, we can see the role of a fairy tale hero emerging as an athlete wins an Olympic medal. The classic study by Vladimir Propp (1969 [1928]) has established the universal structural model of fairy tales, which regards the journey itself but also the successfully solved challenges as central to the tale. The model has been used in analysing folklore about athletes also before. ${ }^{3}$

People are motivated to maintain a positive self-esteem and this can be achieved through witnessing the success of their role models or heroes. As a result of experiencing this process, which Habimana and Massé (2000: 22) have termed as reflection, people feel better about themselves in the light of the others' fame. We can describe the national longing for Olympic medals and other victories using this notion, seen as an expression of national reflection. This does not always lead to a positive outcome: the wish to identify with the hero Andrus Veerpalu brought along a situation which was aptly described in the Estonian media as "a collective shock, a national trauma, which has 
assumed even religious features" (Delfi column from April 8, 2011 ${ }^{4}$ ). Not only did the sportsman and his reputation get a strong blow; so did also his supporters and fans. At the same time, Veerpalu's incident was definitely distinct from all previous similar cases: doping cases do not usually end positively for the accused (cf. Canadian sprinter Ben Johnson, American cyclist Lance Armstrong, Finnish skiers Harri Kirvesniemi, Mika Myllylä, etc.). Thus, in a way, the negative event had positive outcomes, as it boosted national feelings and created cohesion among people.

Nowadays, a successful sportsman is simultaneously a celebrity figure. His results are in correlation with the quality of the system he works in (professional team, sponsors, and fans). He represents the entire country and the nation, not just himself. This makes it possible to state that the success of the athlete is also the success of the community, i.e., the nation, and it directly affects national identity and self-esteem. Talking about the connection between sports and nationalism, Jyrki Pöysä has claimed that in the globalising and media-dominated late modern world, it is exactly sports that allows people to experience nationalist feelings in comfortable and (mostly) safe settings, although in some cases nationalism can change from open-minded patriotism into banal, aggressive and xenophobic hooliganism (Pöysä 2004: 56).

The image of the Olympic athlete as a mythical hero is not very different from (quasi-religious) belief. This is an emotional question: it has almost nothing to do with the rational and measurable facts like doping test results or other numeric entities. People's attitudes are based on subjective evaluations on both group and individual levels. In the context of the current article, the notion of belief is treated as a metaphorical (or rhetorical) expression of trust towards the national hero. This belief displays similar features of worshipping celebrities. István Povedák, while writing about celebrity cult in Hungary, has maintained that "the cults of different celebrities hold religious components to a different degree. [...] This kind of celebrity cult can function as religion in sub-cultural level and can act as religion among fans" (Povedák 2009: 9). This is defined not as vernacular religiosity but rather as quasi- or pseudo-religious belief.

This is not the first time that doping scandals have affected the Estonian sports communities; this has also happened before. For example, on January 23, 2002 (just prior to the Salt Lake City Olympic Games), the Estonian Ski Association received a note from the International Ski Federation that the most successful Estonian female cross country skier Kristina Šmigun tested positive in a doping test. Yet, the B-test results, disclosed a week later, were negative, and overruled the accusations. She ranked seventh in the competition, which was much lower than had been expected, and the rumours suggested that the 
accusations had been a deliberate sabotage with the aim of weakening the athlete psychologically before the important test of strength.

The following question and answer joke was popular at the time, although today it needs an explanation even for an Estonian audience: "What is the difference between an Estonian and a Finn?" - "The Estonian has a negative Btest". The joke which must have boosted the national feelings of the Estonians referred to Finnish athletes who had tested positive in both A- and B-tests. The case found resonance in tongue-in-cheek comments about the case, bringing out ethnic stereotypes about the Finns. The joke no longer works after the Veerpalu doping scandal. Nevertheless, it would be fruitful to inquire in future research which ethnic issues were taken up in Veerpalu's case.

\subsection{Conspiracy stories}

Contemporary conspiracy stories about doping scandals form a new subgenre of sports folklore, displaying common features with urban legends and quasibelief. The narratives, based on a conviction central to the story, carry a distinct moral and are usually spread as anonymous rumours (Kalmre 1996: 137-139). The doping stories that are disseminated in the Internet commentaries also address (allegedly) true events; although they contain supernatural elements and may be ironic, they are still believable.

Researchers have pointed out that similarly to present-day urban legends, conspiracy stories are also told in crisis situations. The general atmosphere of suspicion and fear, poor availability of information through the institutionalised channels, its vagueness and even inconsistency are typical of such situations (Kalmre 2000; Fine \& Ellis 2010; Madisson 2012). The excess of information from multiple sources on the Internet may often lead to an opposition between mainstream and alternative media. Researchers have noticed that the "official truth" reported in the mainstream media may become the synonym of a lie in the alternative media (Renard 2005: 225), and the belief in conspiracy theories engenders the scepticism towards public institutions and their statements (e.g. Keeley 1999: 121; Dentith 2012: 84). The same conditions were present in Veerpalu's case. Although plenty of information was being presented through the media, its content was often contradictory and did not provide reliable facts. People were uncertain if they should believe in the athlete who claimed to be innocent. The media carries an important role in the process of creating rumours, but it is not able to answer all the questions that people might have. Conspiracy theories tend to offer putative explanations for the data unexplained by or contradicting the alternative information (Coady 2006: 119). Besides, journalism 
sends out fuzzy signals that force the audience to build their intuitive theories on the existing information, complement this by fantasies, and rely on earlier experiences with similar events. Like other forms of contemporary legends, conspiracy theories are most effectively spread in the context of overall confusion. The conspiracy stories that appeared in connection with Veerpalu's case definitely did not point to the "truth", but they did indicate the attractiveness of the topic. The doping stories supported the importance of the subject matter: it was intriguing, topical and worth retelling.

The depiction of doping scandals in the media is a broad research topic. Varied accounts of the issue often reach beyond the limits of sports-related groups. For the outsiders, the stories are more about the reputation of the nation and the country than strictly about sports. The audience reacts to the doping scandals by taking sides, displaying their prejudices and telling stories. Speculations about forbidden substances in sports are reinforced by the increasingly dominant and institutionalised intolerance towards doping use, but also by the fact that there have lately been many doping cases. All these scandalous events instantly get reflected in the media and reach the interested audience. One of the most talked about cases on the global scale in the recent past was the doping scandal of American cyclist Lance Armstrong, whose all seven victories of Tour de France were annulled by the International Cycling Union, and the United States Anti-Doping Agency (USADA) banned him from competitions for life. In this case, the prevailing attitudes in the media reflect the disappointment with the athlete, the sense distance from him, and negative opinions about his dishonest behaviour.

\subsection{Humour and irony in online comments}

Irony conveys a subversive meaning in a seemingly straightforward manner. It is double-voiced, creating an incongruity between what is being said and what is meant. Linda Hutcheon, in her seminal book about irony (1994), argues that marginalised groups (in her discussion, the postcolonial and feminist ones in particular) use irony as a playful counter-discourse to make a general point about the dominant, serious one. Irony is thus a play with crucial concepts in a non-bona-fide mode, and its message is masked by seriousness, e.g., through the adoption of the prevailing serious form of communication. Jūratè Kavaliauskaitè (2009), writing about ironic discourse in the media, focuses on the intertextuality, both in form and content, that it is based on. Playing with genres and ideas is a common feature of the ironic discourse. Jamie Warner (2008) maintains that stressful events (taking 9/11 in the USA as a case in 
point) bring about irony that feeds on the dominant serious discourse that rigidly labels all interpretations deviating from the official ones as "suspect, unpatriotic, or even treasonous", arguing against those who have interpreted such events as the end of irony (ibid.).

In Veerpalu's case, monochrome dualism became the powerful interpretive frame for the audience; they were divided into believers and non-believers. In addition to that, there were people who refused to be governed by this frame they were the proponents of the ironic discourse. They did not take the categories of right and wrong too seriously, instead opting for criticising the dualist point of view as such and its reflection in the media.

Another aspect that needs to be taken into account is the fact that the source of the material for the present analysis is the Internet, where humour and irony are frequent phenomena. Playful sequences of conversation can be encountered in different online contexts to a different degree, depending on the nature and function of this environment. Online playful comments are socially gratifying because they express feelings and attitudes (Virtanen 2013: 270), be they sincere or ironic, and this immediately attracts the audience. It is a time off from the main concerns, without verging too far from the main topic. The abundance of playfulness, humour, and wit, particularly in synchronous modes of computer mediated communication, has been amply documented (see, e.g., Danet 1995; Danet et al. 1997). Ray Oldenburg (1999) argues that seriousness is often disliked in online communities; instead, frivolity, verbal word play, and wit are appreciated. Although it has been hypothesised that due to reduced cues and subsequent greater risks of misunderstanding Internet users would be careful with using either humour or irony, research shows the opposite (e.g. Hancock 2004). The analysis of the ironic discourse is essential in Veerpalu's case because playful attitudes expressed in online comments provide a powerful alternative for the serious discourse.

\section{ANALYSIS AND DISCUSSION}

\subsection{Chronology of the case in the media}

The World Anti-Doping Agency (WADA) found forbidden substances in Andrus Veerpalu's A-test taken on February 14, 2011. This was supported by a positive B-test analysed in a German laboratory on April 5 and 6 of the same year. In between these dates, on February 23, Andrus Veerpalu announced at a press conference that he was going to end his career. The first snippets of information about the doping case, however, did not start to circulate much before the 
end of February and the beginning of March, when the article by Tuuli Koch and Peep Pahv (2011) was published in the newspaper Postimees on April 2. The sensational article that explored the claims about positive A-test results (discussing information that was obtained from an anonymous source) caused much reverberation among the audience.

In the following days, the public, shocked by the news, quickly organised support groups for the athlete. Sports enthusiasts and firm believers in Andrus Veerpalu's innocence created a Facebook community "We believe in Andrus Veerpalu". In addition to that, public meetings took place in order to support the sportsman. Public anger and indignation was channelled, among other ways, into a communal enmity against the first article published in Postimees. These feelings were expressed in open protests against the article, its authors, and the newspaper itself.

The belief in the innocence of Andrus Veerpalu was vested in prior media reflections of his predominantly positive character as an honest sportsman. Before the decisive date of January 29, Andrus Veerpalu had taken over a hundred doping tests, and none of these had shown any traces of forbidden substances. A test taken in Davosi training camp at the beginning of February, the same year, just before the one that gave the unfortunate result, was also clean. All his compulsory doping tests from before and after Olympic and World Championship competitions had been negative.

\subsection{Material and methods}

For the analysis, responses to the news texts and articles related to the doping scandal were collected from the news portal Delfi (www.delfi.ee). Asynchronous observation of Internet communication was used to select the most relevant articles concerning the doping case. Although well over 300 news texts were published in the portal during the period of observation - characterised by introducing multiple, sometimes contradictory points of view and having diverse effects on the audience - the material includes a selection of 30 news texts and their comments (threads ranging from containing 30 to 1150 single posts). These were chosen to represent the crucial moments in the long-lasting public dispute over the scandal. The majority of the threads were recorded from the beginning of the scandal in April 2011, when the topic was still "hot"; the intermediary stages (e.g., those articles that dealt with postponing the court hearing of the case) were included in the material; and finally the numerous comments that followed the article concerning the final decision and rehabilitation of the hero, "Veerpalu Won in the Sports Court!" ("Veerpalu sai spordikohtus võidu!"5), published on March 26, 2013, were added, forming a quarter of the entire dataset. 
The active involvement of Delfi commentators and their pervading interest in the topic was visible all throughout the period, but the article announcing the positive decision of the court (from March 26) was most intensely commented on. We may hypothesise that the reason for this was a general feeling of relief of tension, the need for reinstating the hero, and the feeling that this might be the last chance to speak up on the issue. Furthermore, the media had been withholding information at the beginning of the scandal, handing out only small pieces of the whole puzzle in daily write-ups. These were also actively commented on; yet, the final article was preceded by a long silence, and all the interested commentators finally had a chance to express their concluding opinion in the matter. The total number of comments collected for the study was 4000 .

For comparison, Facebook postings related to Veerpalu's case were collected, mostly expressing support for the athlete - e.g., volunteers who offered to translate and post research results on the topic of growth hormones - but also representing the ironic discourse through humorous posts. The most visible of these communities was titled "We believe in Andrus Veerpalu".

\subsubsection{Characteristics of the media: Delfi and Facebook}

Delfi news portal is the most popular commentary board in the Estonian online media. It is also the least regulated environment for public discussion on the Estonian Internet. As such, it is the most suitable source for studying public sentiments and their relation to larger scale cultural phenomena and processes like creating myths and rumours, negotiating matters concerning (national) identity, etc. It displays and even intensifies the wide range of opinions that the Internet users have. In the course of actively advocating one's point of view, opinions clash and become more delineated. The popularity and diversity of the particular environment justifies our choice of material and explains the omission of others. For example, the biggest daily newspaper in Estonia, Postimees, was left out of the sample because its comments represented only a narrow section of the public opinion as this newspaper published the first article of the topic and subsequently became the object of public loathing and attack, mostly against the unethical approach of the journalists. Delfi commentators expressed a greater variety of opinions, although the impulse to attack the media, the messenger, is not absent from there either. A study of the media responses to Veerpalu's scandal maintained that the majority of the articles were biased (Haavala et al. 2011: 15), and this affected the opinions of the audience. Not only the comments themselves but also the news texts that sparked the online discussions were often formulated in an emotional and provocative style. This 
constitutes a perfect hotbed for rumours, stereotypes and conspiracy stories, while rational dispute becomes less attractive.

Equally relevant to the research questions (see below) is the analysis of social media content. In Facebook people post under their real names and this affects the content of their posts. Besides, their attitudes were more positive to start with because the community was meant for Veerpalu's supporters. The community "We believe in Andrus Veerpalu" grew hour by hour right after it was created and reached over 60,000 members. Facebook users simultaneously "unliked" Postimees for its critical approach towards the scandal and the athlete. ${ }^{6}$ The popularity of the community shows clearly how national feelings can be invigorated and actions stimulated by the news concerning a sportsman who has earned the admiration of the nation. In fact, the public show of affection reached such magnitude that a foreign journalist commented on that in the article "Only a Revolution Has Seen Greater Public Feelings" (2011). The article described the Facebook community as an extraordinary case of public involvement and compared this public reaction to other countries that have a history of similar doping cases. The author concluded that if the doping scandal had taken place in the USA or Great Britain, the athlete would have suffered public disgrace, whereas the Estonians mobilised themselves in order to support their hero. During the first 24 hours, 50,000 "believers" who were convinced that Veerpalu was innocent joined the community, which is equivalent to 250,000 people in Great Britain, but which is most unlikely to happen there (ibid.). Other supportive communities also followed the case, for example the community "Revenge on the Estonian Media" ("Tagasilöök Eesti meediale")7, created

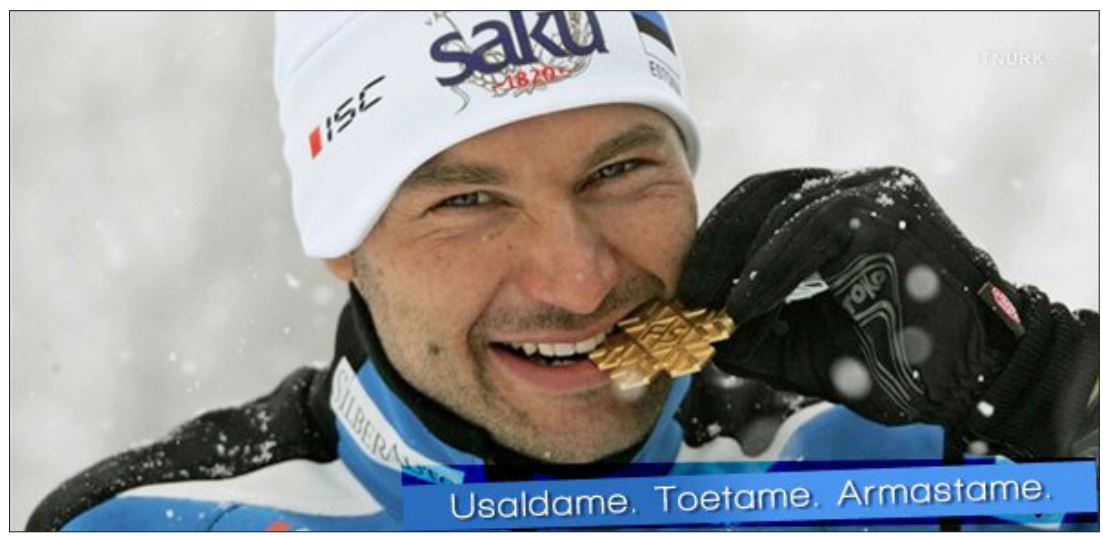

Figure 1. Supportive picture with the caption "We trust, we support, we love!" from the Facebook community "Revenge on the Estonian media" site (http: / / www.facebook. com / photo.php?fbid=178960598818880\&set=a.178960595485547.35199.1789120588 $23734 \&$ type $=1 \&$ theater . 
on April 8 (see also Figure 1). Its main aim was evident in its slogan "Revenge on the Estonian media for tearing Andrus Veerpalu apart during tough times!!"

On April 10, meetings were held in the main squares of some Estonian towns, and human chains were organised through the social media, e.g. "Human chain / meeting to support Andrus Veerpalu" ("Andrus Veerpalu toetuseks inimkett/kogunemine") ${ }^{8}$.

The mushrooming of support campaigns was soon attacked by opposition groups. On April 8, a community under the name "We believe in Santa Claus" ("Usume Jõuluvana") ${ }^{9}$ was created. Both the slogan ("The man who has brought us Christmas for a number of times, the provider of the real winter feeling, the man in our hearts, has lost people's trust! WE BELIEVE IN SANTA CLAUS!") as well as the profile picture (Santa, wearing skis, is set to a winter landscape, and the caption "Sportsman/Athlete"; see Figure 2) refer to Veerpalu's case. The community did not become particularly popular (gathering less than a thousand members by February 5, 2013) and it remained an interesting pe-

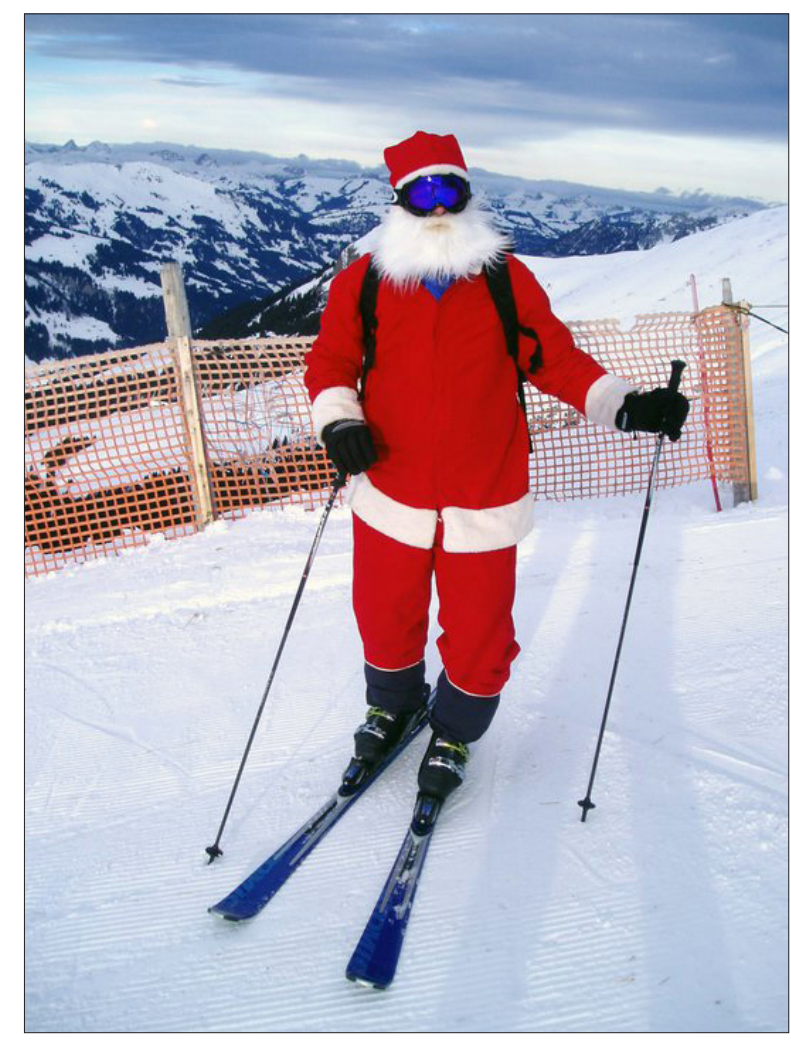

Figure 2. The profile picture of the Facebook community "We believe in Santa Claus" (https: / / www.facebook.com / pages / Usume-Jõuluvana / 216788421669360). 
culiarity rather than the mainstream. It is possible to suggest that the nation was not yet ready to joke about the issue, and that this accounts for the small number of likes in the "Santa community". What is more likely, though, is that people did not simply consider this group attractive enough. This community is by no means the first to satirise popular social phenomena. Estonian online society has a considerable history of social criticism, and there have also been similar subversive communities that aim at undermining an initiative, event, or phenomenon (e.g. "Will this cucumber get more fans than Edgar Savisaar [politician]?" cucumber that everybody worships?"11; etc.).

The two separate datasets, comments and Facebook posts were then analysed by using qualitative data mining software Leximancer, in order to pin down the main concepts ("concept seeds") in the material. The analysis indicates that the central theme evident throughout the data is that of belief. Other slightly less relevant concepts include the opposition between "us" and "them", or "me" and "the people". Constantly recurring concepts were also those connected with the technical vocabulary used in the scandal: growth hormone, WADA, Ski Association, etc. This justifies the setting of the focus of analysis on the notions of belief and trust.

The questions central to the analysis are the following: (1) How is the information provided by the media interpreted by the audience and what topics do these interpretations bring to the table? (2) How does the notion of belief emerge in the discussion, what is being believed in, and what is the justification for the belief? (3) What folkloric and other cultural texts have taken inspiration from this doping scandal?

\subsection{Belief, trust, and related topics}

The national trauma, collective shock and the subsequent reaction (referred to as "revenge" in one of the online communities) was described quite adequately in the Delfi column from April 8, 2011". The column was titled "We believe in Andrus Veerpalu" (citing the Facebook group), and it explained the whole process by placing it within a religious discourse:

There is a martyr (Veerpalu), there are believers ("If you are real Estonian, you'll believe in Veerpalu!"), and there are heretics (journalism and the rational part of the audience). There are only two choices - you are either with us or against us.

This extract also illustrates the strong polarisation of opinions. 
On February 23, 2013, the Delfi news portal organised a Gallup poll entitled "What to think about Andrus Veerpalu's doping case?", in order to establish the dominant opinions of its readers. 3212 people voted for one of the four claims that were postulated by the journalists working in the portal: (1) Veerpalu was unjustly victimised, it was a conspiracy (26.4\%; 848 posts), (2) faulty doping tests produced the positive results $(48.7 \%$; 1563), (3) Veerpalu was treated justly, there was something suspicious about all this $(9.9 \%$; 319), and (4) positive doping tests are not accidental, and everybody says they are innocent in the beginning (15\%; 482). Although none of these statements address the topic of belief directly, they are all implicitly based on the notion, examining whether people believe that Veerpalu was unjustly victimised and they still trust him, or if they believe that he was guilty and has, as a consequence, suffered a considerable loss of trust.

The media introduced the topic of belief right from the beginning and fostered it throughout the scandal. The abovementioned Delfi column from April 8, 2011, states:

Veerpalu's words "I can swear that I have not used any forbidden substances" are trustworthy enough for these people [the fans]. His words are enough to believe in his innocence.

"These people", whose firm belief is displayed in the article, remain true to their inner convictions and are the real, whole-hearted supporters of the athlete: "I believe in Andrus Veerpalu and his entire team. I hope to God that this mess will end one day and justice will win" (virukas...... to Ruu, Delfi, June 12, 2012 ${ }^{13}$ ).

Supporters claimed to be behind him during the difficult times, praising his positive characteristics:

[...] Veerpalu is a tough guy and has brought Estonia so much fame. Skiing broadcasts will now surely be cancelled. Nobody is interested in an athlete who ranks 28 th in a competition, even if this is regarded as success. (Ambur, Delfi, April 6, 2012 ${ }^{14}$ )

A number of those who firmly believed in him stressed the unreliability of the testing method. In order to find a rational and most objective justification for their belief, they built their argument on the fact that a high percentage of growth hormone in the human body is biologically normal and this does not prove the administration of any forbidden substances. This claim was proved true in the court by a team of Estonian top scientists and it finally became the basis of Veerpalu's subsequent acquittal.

Commentators also felt that there had been an attack on the Estonian national image: 
[...] the aim of the opposition is to prove that they have always done the right thing and that there was a doping substance in the athlete's blood - but if there is even a slight chance that he has not intentionally done anything wrong and the accusations against him have been unjust, we have to do all we can to protect him. His whole life, as well as that of his family, has been ruined; the sports-related reputation of the nation and the state has been torn down. (Ruu, Delfi, June 12, 2012 ${ }^{15}$ )

From there on, it was only a small step to the dissemination of all kinds of conspiracy theories, which were quick to emerge in the atmosphere of misinformation, mistrust, and suspicions. Plenty of coincidences reinforced these stories: for example, as Veerpalu was seen as the main competitor of the Norwegian skiing team, this gave rise to rumours about a "Norwegian conspiracy". This theory was further supported by the quite remote fact that the newspaper Postimees, which was the first to address the issue in the media, belongs to the Estonian Media Group, and this in turn is a part of the Norway-based Schibsted media conglomerate. The comments argued that as the sportsman is only "a small pawn in a great game", the doping case may be an act of revenge. This argument was also presented in the context of another "lead" in the story, the recent speculations about the coach of the Estonian skiing team, Mati Alaver, leaving to coach the Russian women's skiing team instead:

The reasons here might be connected to the fact that Alaver has postponed his reply to the Russian skiing team. If things are as they are with Andrus [Veerpalu], then it is highly unlikely that he [Alaver] will ever get the job. (Spordisõber, Delfi, June 6, 2011 ${ }^{16}$ )

Or, developing on the same idea:

I wonder why Delfi attacks Veerpalu in such a bloodthirsty manner - it aims at humiliating the guy as best as it can. Has the poisonous stance been ordered from above? This leads to the question whether this is revenge against Alaver who dared to think of joining the Russian team [...]. (vandenõuteooria, Delfi, April 8, 2011 17 )

Some commentators were quite resolute in their opinions, backing up their support and belief with a conspiracy theory:

I have watched his beautiful skiing for years. I BELIEVE IN HIS INNOCENCE 100 PER CENT. I BELIEVE THAT HE IS ALSO SUSPECTING SOMETHING. (Idavirulane, Delfi, June12, 2012 18 )

Similarly to almost all topical events that are reflected in the media, the case was transferred to and became intertwined with other areas of life, e.g., politics: 
"Such a pity that veerpalu is as rotten as the state of Estonia... fish rots from the head!!!!” (kahjuks jah, Delfi, April 6, 2011 ${ }^{19}$ ).

There were also people who sincerely believed that Veerpalu had taken forbidden substances; although their belief was in opposition with the ones who believed in the athlete's innocence, they were equally sincere in their attitude. The uniting aspect is that there is no underlying irony in their statements. They voiced their support even though they believed he had sinned. The commentators also stressed that even if Veerpalu was guilty, this was not a new thing or a problem; it was just a trifle: "Hey you naive people, all the top athletes do doping, be it forbidden or yet unlisted... the question is who has the best developed sports medicine" (vr, Delfi, April 6, 2011 20 ). They claimed that, as taking doping is the norm, there is nothing spectacular about this particular case:

I would like to know who does not use these substances. Everybody does; why would you think that people just get faster for no reason? This is illogical - as illogical as that people have evolved from apes. In this case new ape-men would be evolving every day:))). (mök, Delfi, June 12, 2012 ${ }^{21}$ )

Another commentator expresses a similar opinion, pointing out that everybody uses doping, but not all get caught: "Well who would not use doping (or asthma medications) in contemporary sports? Everybody does, only in some cases it doesn't dissolve from the body before the right time, etc." (Kalle, Delfi, April 6, $2011^{22}$ ). Some accuse the audience who look for culprits: "Only the naive believe that top sportsmen run on porridge and potatoes, regrettably this is what life is like and it is unjust to call anyone names" (ibid., Delfi, April 6, 2011 ${ }^{23}$ ).

The widely spread and popular discourse of sincere (dis)belief is complemented and opposed by an ironic and sceptical discourse that displays superiority towards the sportsman, the whole scandal, the media, etc. It is subversive towards all the passionate and honest discussions and foregrounds an attitude of indifference. This is evident in a number of negative or ironic comments, but also in the multiple humorous parodies of the scandal. Ulla Lipponen has stated, talking about an earlier doping scandal in Finland in 2001, that this discourse did not appear right after the event - people, shocked by the news, were unable to joke about the matter (cf. Lehtinen 2001: 13). After some time, however, humour became prevalent (ibid.). These two discourses, sincere and ironical, are in no way clearly delineated; they may intertwine in a number of ways.

The ironic discourse is often related to the critical discussion about the media, especially the professionalism and the issue of journalism ethics. The most 

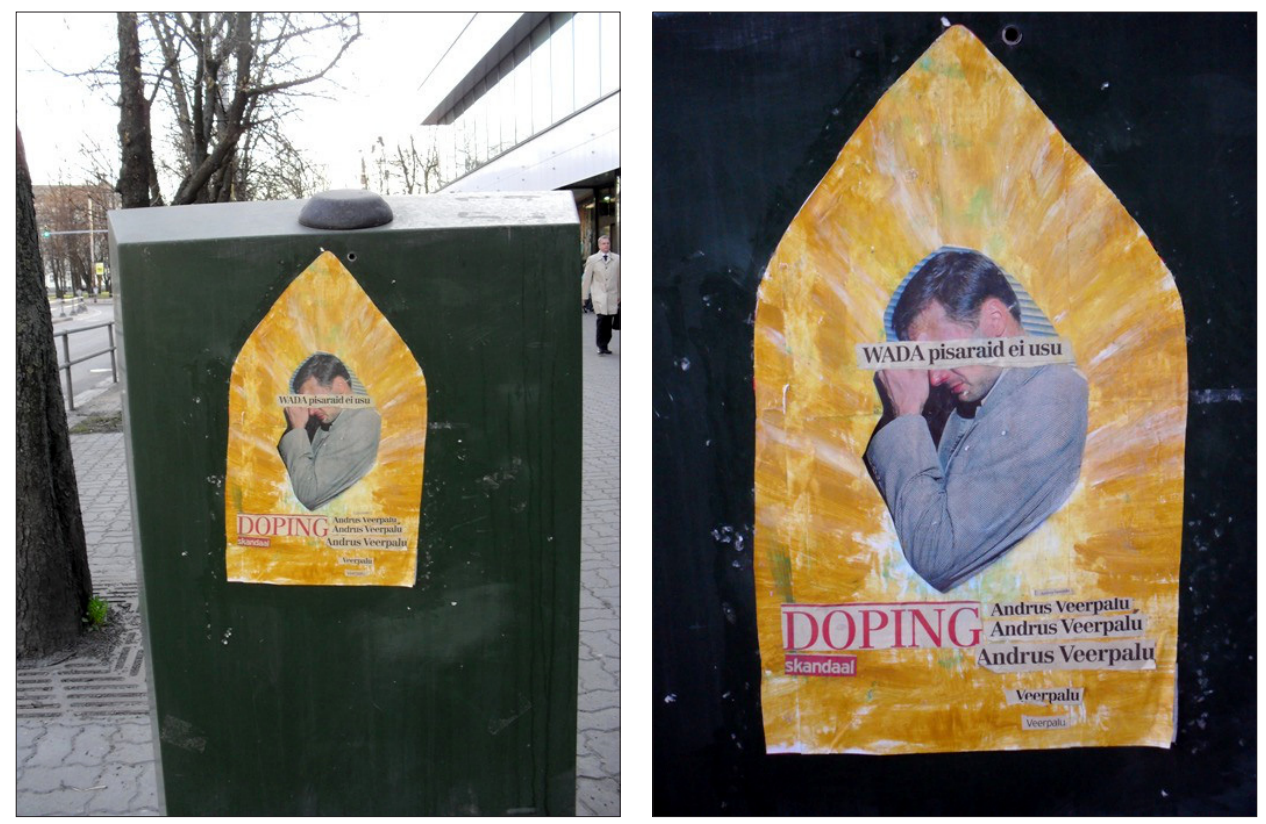

Figure 3. One of the few picture manipulations entitled "WADA does not believe in tears". This refers to a Soviet blockbuster "Moscow does not believe in tears" (mostly on the linguistic level), as it brings about the topic of belief and tears and has become a widely known phrase in the Estonian colloquial language. There was one copy of the poster in Tallinn, and the image was later spread on the Internet (e.g. http: / / urbanepiphany.wordpress.com/page/5/).

frequent question is why the media are so prone to spread accusations and who benefits from the excessive campaign of denigration of the top athlete. The speculations take the form of various rumours, some of which were addressed above. The critique does not spare the Estonian Ski Association:

THIS MEANS THE ENTIRE GANG WHO BELONGS IN THE ADMINISTRATION OF THE ESTONIAN SKI ASSOCIATION HAS LIED TO US!!!! SO - WE CAN'T TRUST THEM IN OTHER MATTERS EITHER!!! (nii on, Delfi, April 6, 201124)

There were also some comments that imitated journalistic style, to criticise the media for spreading the rumours and confusion (referring to several members of the Estonian government):

Here's how we should do it: the print media has to first find an official source and bring hard facts on the table, or we will not discuss the topic 
any more. Nobody [in this forum] has to confute the rumours. We can well blat about Ansip being an alien and it's the truth - until he refuses to comment on the topic. And then we take aim at the next public figure... Laar has an illegitimate child. People smoked pot on Lang's birthday party. Keit Pentus is actually a man, but for 10,000 Euros he agreed to dress as a woman so that there would be at least one female in the Estonian government... Actually I would have nothing against it if Keit Pentus now refutes the statement by posing on the cover of Playboy... So, "free journalism", fire away! (qwe, Delfi, April 6, 2011 ${ }^{25}$ )

In a similar vein, the insufficient and in some cases misleading information is paired with a more generalised critique against the Estonian media as a whole:

Doping scandals are not a recent invention and they have to be publicly addressed. This is done everywhere. But the way Delfi, Postimees or Ekspress [the biggest news portal / daily newspaper / weekly newspaper] present the topic is rather like a vulgar witch-hunt, which has nothing to do with journalism. The so-called "news" was only meant to raise the number of readers and earn yellow money. (Rusikas, Delfi, April 8, 201126)

The disbelievers who refrain from referring to a "bigger plan" as a way to deny or belittle Veerpalu's own share of responsibility in the event are straightforwardly negative towards the athlete:

I can't stand this whining anymore. If you have shit in your pants, it's obviously you who shitted in them. That's it. There is no more hero. He just had to soil himself just before the end of his career because of greed and hunger for fame. (sic transit gloria mundi, Delfi, April 8, 2011 ${ }^{27}$ )

The article (Soonvald \& Rinaldo 2013) that first announced the positive court solution to the audience needs individual attention to document the various emotions and attitudes that were prevalent at that time. The article collected 1150 comments, and the majority of these were carried by feelings of joy and exaltation; people congratulated each other, the "believers" pointed post-factum at the correctness of their previous judgements and at the foundations of their blind belief that the scandal could not affect in any way: "It really doesn't matter what they have decided. In any case Andrus has offered us unbelievable thrills throughout many years and nothing can erase these memories. :)" (Jaak, Delfi, March 26, 201328).

It is also worth describing the ironic reverberations of the topic in channels other than journalism. The case was addressed on December 31, 2012, in a parody in the yearly New Year's Eve programme Tujurikkuja (Moodspoiler). 
Märt Avandi and Ott Sepp, an Estonian comedy duo, made a sketch entitled "We believe in Ita Ever" ("Usume Ita Everit"), where the famous actress is accused before a panel of judges for performing all the best of her roles under the effect of forbidden stimulating substances. The parody evoked numerous reactions, including an almost immediate creation of a Facebook community page "We believe in Ita Ever!" ("Usume Ita Everit!")29, which acquired over 2000 members by the next day (by February 5, 2013, there were 3588 members to this community).

\subsection{Topical humour}

A number of virtual fights were held in the online community at the beginning of the scandal - as soon as someone intended a joke at the expense of their "god", commentators reacted immediately and sharply, and the consequent discussions all led to the topic of belief. The shock, lack of reliable information and an overall complexity of the issue did not give much ground for joking (cf. Laineste 2009: 58, on the best conditions for jokes to arise). Folklore, including narratives and humour, has been noted for its therapeutic effects (see, e.g., Kaivola-Bregenhøj 2005: 311; Kalmre 2009; Kuipers 2002: 453). The shock is relieved through jokes, although not very much so in this case. The commentaries cite or create only a few jokes about the doping scandal. However, the Facebook community "We believe in Andrus Veerpalu" was more prone to sharing doping jokes. The plots referred to the strong rivals of the Estonian skiers, for example, Norwegian cross-country skiers (e.g. Odd-Bjørn Hjelmeset), whose innocence was also commonly doubted at the time:

Yesterday I had a dream... I saw that Hjelmeset (after the recent events) is visiting Otepää... He steps into the local pharmacy, grins widely, and asks: "Do you happen to have growth hormones?" - "Well yes, we do, but we have run out of asthma medications... the problem is that the Estonian skiing team all suffer from asthma and they bought the entire supply." Hjelme looks at the pharmacist in disbelief, his forehead suddenly covered with cold sweat, and storms out of the door... fading untranslatable Norwegian cursing could be heard for some time. That was my dream:). (Facebook community "We believe in Andrus Veerpalu”, April 12, 2011)

This spontaneous anecdotal joke was developed by another community member who added a sequence to the story:

Again, visiting Otepää, Hjelmeset comes out of the pharmacy and complains: "They wanted to punch me in the snout!" A passer-by asks: "How 
do you know?" Hjelmeset: "Otherwise they wouldn't have punched me in the snout!" (Facebook community "We believe in Andrus Veerpalu", April 12, 2011)

The same community shared a joke at the expense of the World Anti-Doping Agency. The unusually big difference between the two tests was a frequently discussed issue in the media. It formed also the main argument for the defence in sports arbitration court, as this decreased the reliability of the test as such:

The WADA spokesman answers questions about Veerpalu's doping test results on an international hearing. A person in a white lab coat stands up and asks if he made the difference between the A and B tests too big (in his report). Spokesman: "Slightly, yes, because this drew unwanted attention to our work!" (Facebook community "We believe in Andrus Veerpalu", April 12, 2011)

Ironic attitude was visible in those posts which joked about the reasons why Veerpalu decided to end his career; for example, hinting that his superiority over his competitors was so great that in order to do them a favour, he had to quit:

Super black humour: [...] his [Veerpalu's] doping tests did not correspond to the competition standards anymore and he thus decided to quit top sports - he had become too superior to the others. I apologise for those who didn't understand the joke: the thing is that he wouldn't need any extra help in competitions :). (Facebook community "We believe in Andrus Veerpalu”, April 12, 2011)

As is visible also in sincere discourse, Veerpalu's doping case was depicted jointly with politics or daily events and problems. In April 2013, a joke spread on Facebook that made fun of the Estonian spring that happened to be very cold. This was taken as a punishment for believing in Andrus Veerpalu instead of God:

"Oh God, please be merciful, let Andrus be freed of accusations!" people pleaded in tears. "Show me that you believe!" said a thundering voice. "We believe! We believe!" screamed the crowd. Things were thus put right and Andrus was redeemed of his sins. "Do you still believe?" asked the thundering voice. "We do!" screamed the crowd. "We have always believed in Andrus. Since the beginning of times!" - "What? You believe in a false god!" God shouted in indignation. "I condemn you to live in a quasi-spring forever, and may you eternally have a bad skiing weather!" (Facebook, April 2, 2013) 


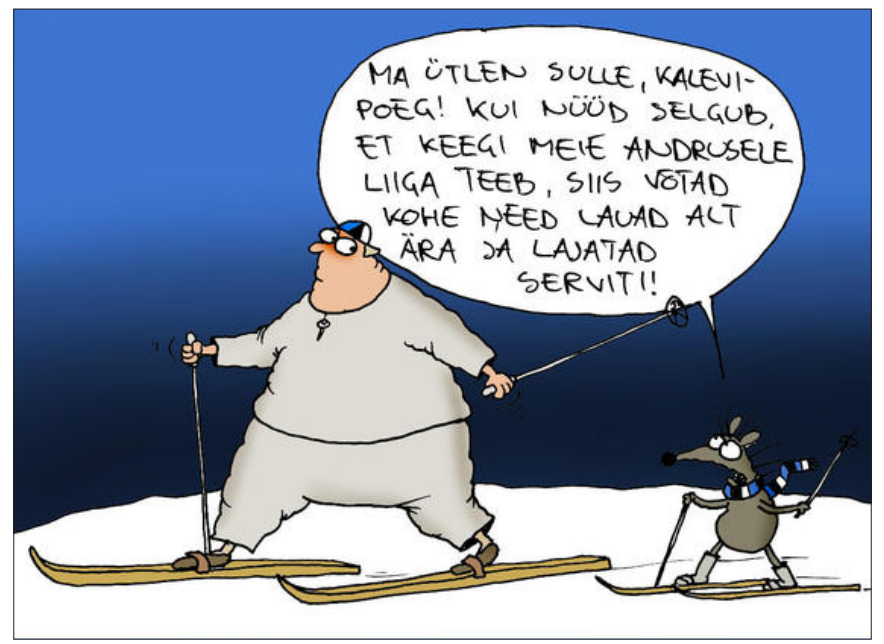

Figure 4. Urmas Nemvalts's daily caricature in Postimees from April 7, 2011, illustrates the column entitled "Hands off Andrus Veerpalu!" (The caption reads: "I am telling you, Kalevipoeg [hero of the national epic]! If now it turns out that anyone wants to hurt our Andrus, then you'll have to take these planks off your feet and lash out!") (http: / / arvamus. postimees.ee /415846 / paeva-karikatuur-kaed-eemale-andrus-veerpalust).

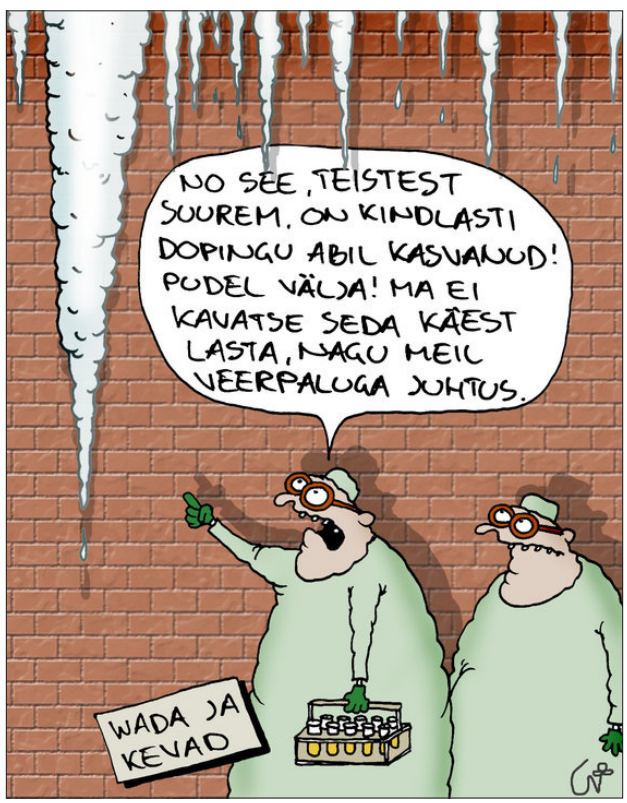

Figure 5. Urmas Nemvalts's caricature WADA and Spring, published in Postimees on March 27, 2013, a day after Veerpalu was acquitted in court (The caption reads: "Well, this one, bigger than the others, must have grown on doping! Bring out the bottle! I will not let it get away from us, as it happened with Veerpalu.") (http: / / arvamus.postimees.ee/1183244 / paeva-karikatuur-wada-jatkab-voitlust). 
The importance of the topic is also echoed in the caricatures published during the discussion, the examples reflecting the general attitudes from the beginning (Figure 4) and end (Figure 5) of the case.

\section{CONCLUSION}

Our aim was to analyse the collective attitudes inherent in the Veerpalu doping case. The main threads in the comments analysed within this study could largely be divided into two opposing, although intertwining, categories: the sincere and the ironic discourse. Within these, there were people who believed in Veerpalu's innocence, and others who did not; besides them, there were those who showed their superiority towards the entire discussion. What was most striking about the particular discussion was that the doping case activated a quasi-religious movement, which was built around the belief that the athlete was sacred, and he must not have been attacked or accused in any way. The main points of discussion, identified in the material, are the strong role of the media in the whole scandal, the question of belief introduced and fostered by the media, and the numerous folkloric narratives that emerged in the course of these two years.

In the Veerpalu doping case, the media shaped the message by introducing the metaphorical and rhetorical concept of belief. This provided a lens through which the whole scandal was seen. The online poll that the Delfi news portal organised in order to find out how strongly the readers believed in Veerpalu's innocence was formulated through the notion of belief. This and other references to belief (e.g., calling Veerpalu a martyr) created a context for the subsequent discussion, framing it as a private as well as sensitive issue. In some cases, the focus shifted away from the scandal and the sportsman. The media discussed

the topic in an inconsistent and confusing manner. To make the decision about Veerpalu being innocent or not was rather a choice based on an irrational belief in the hero than one based on hard evidence. The interpretation of the news is dependent on various factors: the knowledge of the subject, the context made up by related pieces of information taken from the social media or from previous experience, the existing narratives and stereotypes, folkloric texts; all of these convey different subjective truths and are quite far from giving an impartial and objective picture. This in turn forms a perfect ground for conspiracy stories: they take off instantly, inspired by old conspiracy theories and rumours and adding details from the present discussion. In the current case, these stories were quite often connected to important emotional issues, one of which was that of national belonging and stereotypes. Journalists are gener- 
ally interested in nurturing and developing the nationalistic line of narrative because the discussions that trigger nationalist feelings get plenty of public attention and raise the number of readers. Provoking the discussion and making people think along is useful for the media, and this principle is often used in the write-ups, news texts and columns (Laineste 2012: 214). People were aware of the manipulations and unreliability of the media and this was evident in the criticism on how the scandal was presented. Both the sincere as well as the ironic discourse criticised the media for spreading one-sided, unreliable information. In their opinion, the media mined for trouble and intrigue, which was largely unprofessional and unethical.

The topic of belief was developed throughout the discussion and was dominantly present until the end, when the article announcing the withdrawal of accusations was published. We have already mentioned some of the factors that affected belief and trust - Veerpalu's integrity, his image as an untouchable supernatural hero, his almost superhuman displays of strength in athletic competitions, which did not come without much training, hard work and some luck, but also his personality characteristics (honest, taciturn, modest, introvert character, all of which is curiously compatible with the image of a stereotypical Estonian). The tears that he shed at the press conference on April 7, 2011, showed everyone that the hero had been crushed, and this in turn hurt the feelings of almost the entire nation. The more or less genuine belief of the people was reflected through finding justifications for the tragedy and ways to fight against it (above all, through conspiracy stories, but also through social mobilisation to support Veerpalu). In the post factum commentaries, the majority of the people felt that their trust had been justified; they renewed their unremitting belief in the eventually acquitted hero. But the rather complicated end to the long case was also a confusing one, and this allowed for the ironic discourse to produce parodies, jokes and other critical comments.

The Veerpalu case found plenty of reflection in various cultural texts. New jokes emerged, as was shown in the examples above; at the same time, old jokes were being adapted to fit the current doping scandal. Some old jokes that used to be meaningful lost their impact. The parody that received most attention (concerning the actress Ita Ever) played with the idea of denigrating an old, important and hero-like public figure, stinging the media for creating drama as they dragged delicate issues to the open. The ironic discourse present in the online comments added fuel to the fire and it is quite possible that, as a result, the opposition's belief actually strengthened instead of waning. Among positive reverberations to the scandal, there were plenty of visual and verbal texts that were created to support the hero. The slogans on T-shirts of the demonstrators in human chains, posters, and catchphrases that spread like wildfire were 
known among the believers and non-believers alike, and among the latter some of these gave inspiration for ironic texts, for example, in the form of graffiti (as seen in Figure 3). The plot of the drama series entitled Alpimaja (The Chalet), which was aired in 2012, and was quite popular among the Estonian viewers, was also woven around a doping scandal.

The functions of sports have expanded from dealing with only the healthy body and mind into creating and developing social relations. This enables us to think of sports and the related concepts and events not just as recreation, but as a cultural form, and stories about it form an independent folkloristic genre. Any top athlete is a public figure, whose life and actions are under constant surveillance. Everyone is entitled to expressing their opinions about the (mis)deeds, failures, personality characteristics, even the personal lives of athletes. When a public figure is involved in a scandal, his public image intertwined with known folkloric narratives (rumours, conspiracy stories, jokes, etc.) gives rise to stories about heroes, saints, and demi-gods, their journey against the hard fate, finding their destination, and sometimes also a happy ending.

\section{NOTES}

1 Research for this article was supported by research project SF 0030181s08 and grants ETF 8149 and ETF 8137. The authors wish to thank the anonymous reviewers for the valuable comments.

${ }^{2}$ https://www.facebook.com/pages/Usume-Andrus-Veerpalu/194487653920408?fref=ts.

3 Sports historian Kalle Voolaid has compared the lives and careers of two national heroes - the Estonian wrestler Georg Lurich (1876-1920) and the Finnish marathoner Paavo Nurmi (1897-1973) from the point of view of Propp's functions (see Voolaid 1999: 55-64).

${ }^{4}$ http://www.delfi.ee/news/paevauudised/arvamus/juhtkiri-usume-andrusveerpalu.d?id=43583009.

5 http://sport.delfi.ee/news/suusatamine/eesti/andrus-veerpalu-sai-spordikohtusvoidu.d?id=65878360.

6 On April 10, 2011, the community was comprised of the following nationalities: 55,753 Estonians, 2,061 Finns, 848 Swedes, 517 English, 328 Americans, 317 Norwegians, 146 Irish, 140 Germans, 134 Australians, 124 Spanish, 113 Dutch, 98 Danish, 80 French, 76 Italians, 69 Latvians, 66 Belgians, 64 Poles, 38 Luxembourgians, and 33 Russians. Five months after the announcement of positive doping test results, on September 19, 2011 , the number of community members had risen to 66,795 (Facebook community "We believe in Andrus Veerpalu", April 10, 2011).

7 https://www.facebook.com/pages/Tagasil\%C3\%B6\%C3\%B6k-Eesti-meediale/1789120 58823734 ?ref $=$ ts\&fref $=$ ts. 
8 https://www.facebook.com/pages/Andrus-Veerpalu-toetuseks-inimkettkogunemi ne/216430721705353.

9 https://www.facebook.com/pages/Usume-J\%C3\%B5uluvana/216788421669360?fref= ts.

${ }^{10} \mathrm{https}: / /$ www.facebook.com/heakurk.

${ }^{11} \mathrm{https}: / /$ www.facebook.com/pages/Kas-see-redis-saab-rohkem-f\%C3\%A4nne-kui-seekurk-keda-k\%C3\%B5ik-f\%C3\%A4nnavad/108589652511601.

12 http://www.delfi.ee/news/paevauudised/arvamus/juhtkiri-usume-andrusveerpalu.d?id=43583009.

${ }^{13} \mathrm{http} / / /$ sport.delfi.ee/news/suusatamine/murdmaasuusatamine/delfi-lausanneisveerpalu-kohtusaagas-algas-teine-paev-jaak-mae-ilmub-tunnistusi-andma.d?id=64 $528572 \&$ com $=1 \&$ no $=20$.

${ }^{14} \mathrm{http}$ ://sport.delfi.ee/news/suusatamine/eesti/allikas-andrus-veerpalu-a-proov-olipositiivne-sportlane-on-selle-vaidlustanud.d?id=43386223\&com=1\&no=140.

$15 \mathrm{http} / /$ sport.delfi.ee/news/suusatamine/murdmaasuusatamine/delfi-lausanneisveerpalu-kohtusaagas-algas-teine-paev-jaak-mae-ilmub-tunnistusi-andma.d?id=64 $528572 \&$ com $=1 \&$ no $=20$.

${ }^{16}$ sport.delfi.ee/news/suusatamine/eesti/allikas-andrus-veerpalu-a-proov-oli-positiivnesportlane-on-selle-vaidlustanud.d?id=43386223\&com=1\&no=20.

${ }^{17} \mathrm{http} / / / \mathrm{www} \cdot d e l f i . e e /$ news/paevauudised/arvamus/juhtkiri-usume-andrus-veerpalu.d? $\mathrm{id}=43583009 \& \operatorname{com}=1 \&$ no $=40$.

$18 \mathrm{http} / /$ sport.delfi.ee/news/suusatamine/murdmaasuusatamine/delfi-lausanneisveerpalu-kohtusaagas-algas-teine-paev-jaak-mae-ilmub-tunnistusiandma.d?id=64528572\&com $=1 \&$ no $=0 \& \mathrm{~s}=1$.

$19 \mathrm{http} / / /$ sport.delfi.ee/news/suusatamine/eesti/allikas-andrus-veerpalu-a-proov-oli-positiivne-sportlane-on-selle-vaidlustanud.d?id=43386223\&com=1\&no=60.

${ }^{20} \mathrm{http} / / /$ sport.delfi.ee/news/suusatamine/eesti/allikas-andrus-veerpalu-a-proov-oli-positiivne-sportlane-on-selle-vaidlustanud.d?id=43386223\&com=1\&no=20.

${ }^{21} \mathrm{http} / / /$ sport.delfi.ee/news/suusatamine/murdmaasuusatamine/delfi-lausanneis-veerpalu-kohtusaagas-algas-teine-paev-jaak-mae-ilmub-tunnistusi-andma.d?id=645285 $72 \& \operatorname{com}=1 \&$ no $=20$.

${ }^{22} \mathrm{http} / / /$ sport.delfi.ee/news/suusatamine/eesti/allikas-andrus-veerpalu-a-proov-olipositiivne-sportlane-on-selle-vaidlustanud.d?id=43386223\&com=1\&no=120.

${ }^{23}$ Ibid.

${ }^{24} \mathrm{http}$ ://sport.delfi.ee/news/suusatamine/eesti/allikas-andrus-veerpalu-a-proov-olipositiivne-sportlane-on-selle-vaidlustanud.d?id=43386223\&com=1\&no=140. 
${ }^{25} \mathrm{http}$ ://sport.delfi.ee/news/suusatamine/eesti/allikas-andrus-veerpalu-a-proov-olipositiivne-sportlane-on-selle-vaidlustanud.d?id=43386223\&com $=1$.

${ }^{26} \mathrm{http} / / /$ www.delfi.ee/news/paevauudised/arvamus/juhtkiri-usume-andrus-veerpalu.d? id $=43583009 \& \operatorname{com}=1 \&$ no $=0 \& s=1$.

${ }^{27} \mathrm{http} / / /$ www.delfi.ee/news/paevauudised/arvamus/juhtkiri-usume-andrus-veerpalu.d? $\mathrm{id}=43583009 \& \mathrm{com}=1 \& \mathrm{no}=0 \& \mathrm{~s}=$.

${ }^{28} \mathrm{http} / / /$ sport.delfi.ee/news/suusatamine/eesti/andrus-veerpalu-sai-spordikohtus-voidu .d?id=65878360\&com $=1 \&$ no $=60$.

${ }^{29} \mathrm{https} / / / \mathrm{www}$.facebook.com/UsumeItaEverit?fref=ts.

\section{REFERENCES}

Campbell, Joseph 2004 [1949]. The Hero with a Thousand Faces. Bollingen Series XVII. Princeton and Oxford: Princeton University Press.

Coady, David 2006. Conspiracy theories and official stories. In: David Coady (ed.) Conspiracy Theories: The Philosophical Debate. Hampshire \& Burlington: Ashgate Publishing, pp. 115-128.

Danet, Brenda (ed.) 1995. Play and Performance in Computer-Mediated Communication. Journal of Computer-Mediated Communication, special issue, Vol. 1, No. 2. Available at http://jcmc.indiana.edu/vol1/issue2/, last accessed on July 29, 2013.

Danet, Brenda \& Ruedenberg-Wright, Lucia, \& Rosenbaum-Tamari, Yehudit 1997. "Hmmm... Where's That Smoke Coming From?" Writing, Play and Performance on Internet Relay Chat. Journal of Computer-Mediated Communication, Vol. 2, No. 4. Available at http://jcmc.indiana.edu/vol2/issue4/danet.html, last accessed on July 29, 2013, http://dx.doi.org/10.1111/j.1083-6101.1997.tb00195.x.

Dentith, Matthew Richard 2012. In defence of conspiracy theories. Doctoral thesis. Auckland: The University of Auckland. Available at https://researchspace. auckland.ac.nz/handle/2292/17107, last accessed on July 29, 2013.

Fine, Gary Alan \& Ellis, Bill 2010. The Global Grapevine: Why Rumours of Terrorism, Immigration, and Trade Matter. New York: Oxford University Press, doi: 10.1093/ acprof:oso/9780199736317.001.0001.

Frank, Russell 2011. Newslore: Contemporary Folklore on the Internet. Jackson: University Press of Mississippi.

Haavala, Kristina \& Koppel, Annika \& Loi, Karina \& Tuulik, Katrina \& Utkin, Mari 2011. Eesti meedia professionaalsus. [Professionalism in Estonian Media.] Tallinna Ülikool, Kommunikatsiooni Instituut. Available at http://uurimismeetodid. pbworks.com/w/file/fetch/46061836/Meedia_professionaalsus_grupp_2.pdf, last accessed on July 29, 2013.

Habimana, Emmanuel \& Massé, Line 2000. Envy Manifestations and Personality Disorders. European Psychiatry, Vol. 15, No. 1, pp. 1-7, http://dx.doi.org/10.1016/ S0924-9338(00)99501-4. 
Hancock, Jeffrey T. 2004. Verbal Irony Use in Face-To-Face and Computer-Mediated Conversations. Journal of Language and Social Psychology, Vol. 23 (4), pp. 447-463, http://dx.doi.org/10.1177/0261927X04269587.

Hutcheon, Linda 1994. Irony's Edge: The Theory and Politics of Irony. London and New York: Routledge.

Kaivola-Bregenhøj, Annikki 2005. Uusiutuva arvoitusperinne. [Regenerating Riddle Lore.] In: Helena Saarikoski (ed.) Leikkikentiltä. Lastenperinteen tutkimuksia 2000-luvulta. Tietolipas 208. Helsinki: Suomalaisen Kirjallisuuden Seura, pp. 292-334.

Kalmre, Eda 1996. Vorstivabrikutest kassitoiduni ehk mõnda linnalugudest. [From Sausage Factories to Cat Food or Something About Urban Legends.] In: Mare Kõiva (ed.) Mängult-päriselt. Tänapäeva folkloorist II. Tartu: Eesti Keele Instituut \& Eesti Rahvaluule Arhiiv, pp. 136-155.

Kalmre, Eda 2000. Katastroofifolkloorist: Estonia ja Titanic. [On Catastrophe Folklore: Estonia and Titanic.] In: Mare Kõiva (ed.) Meedia. Folkloor. Mütoloogia. Tänapäeva folkloorist III. Tartu: Eesti Kirjandusmuuseumi rahvausundi töörühm, pp. 263-284.

Kalmre, Eda 2009. Legends Connected with the Sinking of the Ferry Estonia on September 28, 1994. In: Mare Kõiva (ed.) Media \& Folklore: Contemporary Folklore IV. Tartu: Estonian Literary Museum Scholarly Press, pp. 288-312.

Kavaliauskaitè, Jūratè 2009. Hybrid Entertainment Television: Viewership of the Lithuanian "Dviracio Sou". In: Arvo Krikmann \& Liisi Laineste (eds.) Permitted Laughter: Socialist, Post-socialist and Never-Socialist Humour. Tartu: ELM Scholarly Press, pp. 99-124.

Keeley, Brian L. 1999. Of Conspiracy Theories. The Journal of Philosophy, Vol. 96, No. 3, pp. 109-126, http://dx.doi.org/10.2307/2564659.

Koch, Tuuli \& Pahv, Peep 2011. Andrus Veerpalu ja doping: hästi hoitud saladus või laim? [Andrus Veerpalu and Doping: A Well-Kept Secret or Defamation.] Postimees Online, April 2. Available at http://sport.postimees.ee/412751/andrus-veerpaluja-doping-hasti-hoitud-saladus-voi-laim, last accessed on July 29, 2013.

Kolga, Voldemar 2011. Andrus Veerpalu kui (müütiline) kangelane. [Andrus Veerpalu as a (Mythical) Hero.] Delfi, April 9. Available at http://www.delfi.ee/news/ paevauudised/arvamus/voldemar-kolga-andrus-veerpalu-kui-muutilinekangelane.d?id=43602631, last accessed on July 29, 2013.

Kuipers, Giselinde 2002. Media Culture and Internet Disaster Jokes: Bin Laden and the Attack on the World Trade Center. European Journal of Cultural Studies, Vol. 5, No. 4, pp. 450-470, http://dx.doi.org/10.1177/1364942002005004296.

Laineste, Liisi 2009. Political Jokes in Post-socialist Estonia (2000-2007). In: Arvo Krikmann \& Liisi Laineste (eds.) Permitted Laughter: Socialist, Post-socialist and Never-Socialist Humour. Tartu: ELM Scholarly Press, pp. 41-72.

Laineste, Liisi 2012. Verbal expressions of aggressiveness in Estonian Internet. In: Liisi Laineste \& Dorota Brzozowska \& Władysław Chłopicki (eds.) Estonia and Poland. Creativity and Tradition in Cultural Communication. Tartu: ELM Scholarly Press, pp. 205-220, doi:10.7592/EP.1.laineste.liisi. 
Lehtinen, Satu 2001. Go Finland Go! Universitas Helsingiensis, No. 2, pp. 11-13. Available at http://www.helsinki.fi/lehdet/uh/201b.htm, last accessed on July 29, 2013.

Madisson, Mari-Liis 2012. Vandenõuteooriate semiootiline tähistamisloogika. [The Semiotic Logic of Signification of Conspiracy Theories.] Akadeemia, No. 6, pp. 1024-1071.

Oldenburg, Ray 1999. The Great Good Place: Cafes, Coffee Shops, Bookstores, Bars, Hair Salons and Other Hangouts at the Heart of a Community. Cambridge, Massachusetts: Da Capo Press.

Only a revolution has seen greater public feeling 2011. Views of an International $\mathrm{Ob}$ server. http://www.aninternationalobserver.co.uk/425, last accessed on April 20, 2011; no longer available.

Povedák, István 2009. Heroes and Celebrities. PhD Dissertation Summary. Budapest \& Szeged. Available at http://doktori.btk.elte.hu/folk/povedakistvan/thesis.pdf, last accessed on July 29, 2013.

Propp, Vladimir 1969 [1928]. Morfologiia skazki. [Morphology of the Fairy Tale.] Moskva: Nauka.

Pöysä, Jyrki 2004. "Finnishness" and "Russianness" in the Making: Sport, Gender and National Identity. In: Anna-Leena Siikala, Barbro Sklute Klein and Stein R. Mathisen (eds.) Creating Diversities. Folklore, Religion and the Politics of Heritage. Studia Fennica: Folkloristica, Vol. 14. Helsinki: Finnish Literature Society, pp. 54-68.

Renard, Jean-Bruno 2005. Negatory Rumors. From the Denial of Reality to Conspiracy Theory. In: Gary Alan Fine \& Véronique Campion-Vincent \& Chip Heath (eds.) Rumor Mills. The Social Impact of Rumor and Legend. New Brunswick, New Jersey: Transaction Publishers, pp. 223-239.

Smutov, Martin 2011. Maineuurija Veerpalu juhtumist: üliemotsionaalses olukorras on valikud must-valged. [In Highly Emotional Situation Choices are Black and White.] Postimees (newspaper), April 8. Available at http://sport.postimees. ee/416239/maineuurija-veerpalu-juhtumist-uliemotsionaalses-olukorras-onvalikud-must-valged, last accessed on July 29, 2013.

Soonvald, Urmo \& Rinaldo, Karl 2013. Andrus Veerpalu sai spordikohtus võidu! Otsus: on viiteid, et Veerpalu tarvitas dopingut, aga testi piirmäärad pole tõestatud. [Andrus Veerpalu Won in the Sports Court!] Delfi, March 26. Available at http://sport.delfi.ee/news/suusatamine/eesti/andrus-veerpalu-sai-spordikohtusvoidu.d?id=65878360, last accessed on July 29, 2013.

Virtanen, Tuija 2013. Performativity in Computer-Mediated Communication. In: Susan C. Herring \& Dieter Stein \& Tuija Virtanen (eds.) Pragmatics of ComputerMediated Communication, Volume 9 of Handbooks of Pragmatics, Berlin: Mouton de Gruyter, pp. 269-290, http://dx.doi.org/10.1515/9783110214468.269.

Voolaid, Kalle 1999. Lurich and Nurmi: Life as a Fairy-Tale? Acta Academiae Olympiquae Estoniae, Vol. 7, pp. 55-64.

Voolaid, Kalle 2001. Jõumehe fenomen: Georg Lurich ajaloolisest tegelasest rahvajutu kangelaseks. [Strongman's Phenomenon: Georg Lurich as a Historic Character and the Hero of Folk Narrative.] In: Tiiu Jaago (comp.) Pärimuslik ajalugu. Tartu: Tartu Ülikooli Kirjastus, pp. 183-194. 
Voolaid, Piret 2003. Jaanuar, veerpalu, märts, aprill, mae... Pilk spordimaailma läbi folklooriprisma. [January, Veerpalu, March, April, Mae ... A Glimpse into Sports World through Folklore.] Mäetagused, Vol. 21, pp. 193-221. Available at http:// www.folklore.ee/tagused/nr21/spordifolkloor.pdf, last accessed on July 29, 2013.

Warner, Jamie 2008. Tyranny of the Dichotomy: Prophetic Dualism, Irony, and The Onion. The Electronic Journal of Communication, Vol. 18, Nos. 2-4. Available at http://www.cios.org/www/ejc/EJCPUBLIC/018/2/01841.html, last accessed on July 29, 2013. 


\title{
VIOLENCE AND ROUGHNESS IN TRADITIONAL GAMES AND SPORTS: THE CASE OF FOLK FOOTBALL (ENGLAND AND SCOTLAND)
}

\author{
Laurent Sébastien Fournier
}

\begin{abstract}
The article addresses old English and Scottish annual village games known as folk football, which still survive along with the more usual federal modern sports like soccer and rugby. The article suggests that the example of folk football enables us to better understand the relationship between sport and violence. The use of the ethnographic method throughout a long-term period allows us to compare different existing games. The article describes aggressiveness in the games and its historical background. It also shows how the authorities tried to control and rule these traditional games. On the field, however, the players argue that the game is rough rather than violent. It is then important to pay attention to the players' viewpoint. Fieldwork on folk football matches shows that violence is drawn off at different levels. The case presented is an interesting one, grasping the relations between sport and violence. The violence that regularly appears in modern sport and hooliganism can be interpreted as an unconscious restoration of very old dual cultural schemes, connected in a broad psychological perspective to the youth's universal taste for pride and parade.
\end{abstract}

Keywords: ethnography, football, sport, tradition, United Kingdom, violence

In England and Scotland, some old annual village games known as folk football still survive along with the more usual federal modern sports like soccer and rugby. Technically, folk football matches feature huge scrums, in which two parts of a given village compete during several hours to bring the ball to the goal. At a social level, the games are typical for the relations they have with the traditional festivals, especially with Shrovetide and the wintertime festivals. Such games, and also their French historical equivalent known as la soule, have often been considered as extremely violent as they damage private property and enable personal revenge (Muchembled 1989). In this perspective, folk football has often been interpreted as a means of reaching catharsis: the traditional games that historically preceded institutionalised sports tended to be violent and acted as a security valve, allowing for some temporary freedom to people. 
On this basis, violence in sports has been historically and culturally legitimised. According to Norbert Elias and Eric Dunning (1986), for instance, the change from traditional games to modern sports follows a "civilising process", according to which modern sports feature a "controlled decontrolling of emotions". By contrast, traditional games such as folk football are typical for their violence and high level of free emotions. In this view, sociologists have often suggested that violence in modern sports is something like an archaism; the time when emotions are not under control anymore (Dunning \& Sheard 1979). From there, violence is often seen as the essence or the origin of sports, and many scholars have therefore focused on violence in sports, either on the field or among the spectators (Giulianotti et al. 1994; Carnibella et al. 1996; Bodin 2003). However, in recent years some social anthropologists have tried to understand the logic of such violence. It has been in particular suggested that violence in sports has more to do with participation in the match as a global social drama than with the sport itself (Bromberger 1995).

In this article I suggest that the example of folk football enables to understand better the relationship between sport and violence. At first sight, the folk football example shows that violence and sport are tightly linked, and even suggests that sport was born out of violence. But is this true? Studying folk football in Britain from the inside leads us to better understand the nature of violence in games and sports.

\section{METHODS}

In order to understand violence in folk football with the game's cultural logic, it was necessary to go beyond the usual statements from the media, almost all of which suggesting that this game is an especially violent one. For this purpose, I decided to use the ethnographic method within a long-term period and to compare different games. From 2006 to 2012, I attended annual folk football matches in seven places in Scotland (Kirkwall, Jedburgh, Ancrum, Duns, Lilliesleaf, Hobkirk, Denholm) and documented other games in four places in England (Ashbourne, Alnwick, Haxey, Workington). In all these different places I collected data on the history of the games and asked questions about violence and other aspects of games from the participants and spectators. In some cases (Kirkwall, Jedburgh, Ashbourne) I was introduced to the main protagonists of the games, including some key-players but also organisers and patrons. I usually stayed in these places for a few days to conduct some interviews with them. I also collected data from the archives of the School of Scottish Studies in Edinburgh, where the games have been documented for a long time as remarkable Scottish cultural practices. 
Concerning participation in the games, I soon realised that it would be impossible for me as a stranger to win a ball by myself. This is indeed reserved for players who have been involved in the games for many years. I could not even participate as a player because the players do not usually wear uniforms and so nobody could tell in which of the two teams I would be playing. However, I spent a long time hanging around the scrums, in the frost, sometimes until late in the night, waiting for the end of the game and discussing with both the players and the spectators. In the games with bigger scrums, in Kirkwall or Ashbourne, where several hundred people get involved, I often managed to jump on fences or on windows in order to get trapped in the game, above the scrum. For several minutes the scrum does not move and it is then possible to see the interactions between the players from very near. Such a position enables to observe the players and understand how they react when there is a sudden break or when the ball comes in their direction. Ethnography helps to understand the techniques and the strategies in the games. As a comprehensive method, it gives quite a different idea of the games than the one usually shown by the media.

\section{FOLK FOOTBALL: A VIOLENT GAME?}

Today, the folk football videos accessible online often show games which have nothing to do either with the official sport ideals or with fair-play. ${ }^{1}$ For instance, in Ashbourne's Royal Shrovetide Football, in Derbyshire, during a big scrum or mêlée in a river, the struggle for the ball is very rough. The players seem nervous and violence is everywhere; some of their heads are strongly knocked about. Some players lift up an opponent to prevent him from taking the ball and the latter answers with violence. Some other videos focus on the so-called ba'game in Kirkwall, Orkney. The images are even worse: some players in the mêlée are violently hit in the face. When somebody is considered to be too rude, the other players bring them to justice themselves. This way of settling quarrels is customary in the game and appears regularly in the same video ${ }^{2}$. In this town, one of the officials explains: " $B a$ ' is a very physical sport and people do get hurt. There have been numerous people with broken bones and black eyes". ${ }^{3}$ This aggressiveness on the playfield must be connected with a more symbolic violence. According to French sociologist Pierre Bourdieu, "symbolic violence" is related to cultural arbitrariness, which "manages to impose meanings and imposes them as legitimate while hiding the social relations that are behind them" (Bourdieu \& Passeron 1970). To put it in other words, symbolic violence lies in the domination of a person, group or society that imposes some ways 
of thinking and makes them look "normal" while making this domination unconscious for the dominated as well as for the dominants. Such domination can easily be found in folk football, which, similarly to every other game or sport, opposes the two teams of players in the hope for victory. The younger players are the first victims of symbolic violence: as the game is very popular among all children, one individual child cannot really choose if he wants to participate in the game or not. Moreover, this symbolic violence is also present within the children's teams and is not limited to the very day of the match: Lynne Fairgrieve ${ }^{4}$, living in Jedburgh, recalls a war between boys' clans, which lasted several weeks after the game. Billie Gillies ${ }^{5}$, a player in the same village, explains that until the $1960 \mathrm{~s}$, such segregation existed among adults as well. The two clans never met and used to go in their own pubs. Today, this is not the case anymore, but still occurs among children. Insisting on such a differentiation does not help to develop fair play or respect for the opposite team.

Lack of organisation adds to the violence of the game. In the little villages that practice folk football, like in Jedburgh or Ancrum, Roxburghshire, nobody cares for the traffic problems, or the casualties, or supervision of the annual encounters. Even if the traffic is limited in these two places, the scrum happening in the middle of the main street could be very dangerous if a car came a bit too fast or if the group of players suddenly broke loose. In the same way, the few "caution" advertisements hardly prevent the car drivers who usually end by driving erratically in the middle of the crowd.

\section{HISTORICAL ORIGINS}

The violence of folk football, however, is not surprising as it finds its origins in the violence of the traditional games before they were codified as sports. Thus, during the 18th century, several fights erupted in Scotland, and on the Islands of the Firth of Clyde, stone fights still regularly occur. Death was considered as normal during such practices, but they were not legally banned (Holt 1990). Moreover, fist fighting was codified in Scotland as a national championship due to aristocrats, pub owners and the customers of the Figg's Emporium boxing club, a place opened in 1719. However, in spite of this early fad, there were no rules in fist fighting until 1743, when Jack Broughton, who killed an opponent in a fight, decided to establish the first ones (ibid.). Another example is the one of fox hunting, which excited the players as if they were killing human beings during the war, according to Norbert Elias (Elias \& Dunning 1986). All these practices show well the violence and the dangers connected with physical activities, games and sports in the past. 
In such a context, folk football was also a game related to violence in the past. The dangers of folk football are easily perceptible if you know that one of the first rules in the Ashbourne game was to save the opponents' lives. ${ }^{6}$ You can wonder how this game took place to apply such rules. Then, it is interesting to recall the Scottish myth of folk football, collected in Jedburgh as well as in other places. According to some Scottish players, the ball represents the severed head of an English soldier, which again shows in which state of mind the ritual was performed. Moreover, the segregation between the teams until the $1960 \mathrm{~s}$, with each clan staying in their own parts of the town, was another form of violence. Folk football matches were a time when you had to prove to an unknown opponent that your own camp was able to hold the town.

Scottish historian John Burnett (2000) quotes a few verses from Walter Scott, who presents traditional football as a metaphor for war in the context of unceasing battles between Scotland and England:

Some drove the jolly bowl about;

With dice and draughts some chased the day;

And some, with many a merry shout,

In riot, revelry, and rout,

Pursued the football-play.

This poem shows that the traditional football matches were seen as huge noisy and illegal gatherings, very different from the other traditional games. Lastly, concerning the practice itself, playing with feet, aiming at a goal in the middle of the water, or cutting the ball into parts with a knife at the end of the game, increased the dangers of being wounded or drowned. ${ }^{7}$

\section{CONTROLLING AND RULING THE GAMES}

All these elements explain that the authorities always tried to control and rule these traditional games which caused much disorder because of their freedom and lack of organisation. Hugh Hornby, an English specialist in folk football, has summed up the different rules and trials against the games in his recent book (2008). The decrees and legal documents are the first evidence of the games. The word "football" appears for the first time in 1314 in a legal document found in London. Nevertheless, this document does not seem to have had much impact, as a few years later, in 1365, King Edward III had to ban the game again. While fighting against football games, the authorities of the time also tried to replace them by more useful activities. Various games had to be used to form skilful warriors in a context of permanent wars against Scotland or France: this is why archery should have been preferred to football. 
In Manchester, a few centuries later, people practicing football were fined. As some windows were broken for the "pleasure of the players", football was first forbidden in 1608. Ten years after, two officers were appointed to ensure that the law was obeyed: any player was fined 12 pence (ibid.).

Today, it is possible to find echoes of these historical legal critiques. Some local people, players or not, speak about their fears concerning the practice of folk football. According to Gavin Scott, a player in Jedburgh, it is dangerous to organise men's and boys' games on the same day. ${ }^{8}$ However, several young boys, sometimes less than 12 years old, do take part in their fathers' games. Given the violence of the actions in the scrum, especially when the game strikes the walls and the barricades, it is likely that a young boy being caught between the game and a house could be quite badly hurt and squashed. In Ancrum, a schoolteacher tried to stop the game because she found it too "barbarian". ${ }^{9}$ If you compare with a few centuries ago, people have become much more sensitive to violence. Whereas the first regulations tried to stop homicides during the matches, the actual claims only concern the risk of children being hurt. Norbert Elias and Eric Dunning (1986) explain this evolution through the "civilisation process", according to which people have become less and less violent and let the institutions regulate their private conflicts.

For other reasons, the shopkeepers in the places where the matches take place often emphasise the risks connected with folk football. On the days of the matches, the windows in the main streets are protected with barricades. This is necessary regarding the nature of the game, especially as the players can easily damage the windows with their shoulders. However, the real problem for the shopkeepers is the loss concerning the sales. In Jedburgh, a butcher explains that the ba' day is not a good day for his business because the sales decline considerably. In another street, a jeweller explains that the game does not disturb her, but that she usually uses this day to draw up an inventory in order not to lose a day. In the same street, another shop prefers to take a day off. On the days of football games, anyway, a significant part of the population do not dare to come downtown at the risk of being knocked down by the group of players.

The practice of folk football, like all the free traditional games, is also a problem for the public order. Indeed, these games still sometimes need police intervention. This was, for instance, the case in Jedburgh, during the 2005 game, when the police had to arrest one of the players who had been denounced as being violent with other players in the scrum. Of course, such outbursts are difficult to avoid, because even if most of the people want to promote respect and fair play, there are always some individuals who come for a fight and go crazy in a game without any formal and accepted standards. Furthermore, problems 
concerning public liability and damage done to private property have often been raised, together with the traffic problems, to ban the games. ${ }^{10}$

In these conditions the town councils have often become reluctant to continue the games. As nobody is legally responsible, it is the town that has to repair the damage or take responsibility for the injured people. This topic has been discussed in Kirkwall where some officials have asked to stop giving public subsidies to folk football. Indeed, each year the local town council pays for the damage, repairing doors and windows of private houses, for instance when a whole wall was pushed down by the pressure from the scrum. Nevertheless, the most important threat here is connected with the risk of a player or an onlooker being injured because of the game. People go to court more and more frequently, attacking the public institutions which support the games, in order to get some financial compensation for the injuries caused by the games.

\section{IN THE PLAYERS' VIEW}

On the field, however, the players argue that the game is rough rather than violent. Hugh Hornby (2008), convinced that folk football is part of the British cultural heritage, protects the games from the danger of becoming too much organised. According to him, the world of folk football can survive only if it is not trapped in liability problems and if it manages to escape the "health and security" issues. Otherwise it could quickly be overwhelmed by a whole set of regulations which would lead to its disappearance.

Furthermore, there are no statistics proving that these practices would cause more injuries than the modern sports. While scrutinising the figures, Hornby (2008) counted only 9 dead players in folk football matches since 1800. Five were drowned, two had a heart attack, one died because of hypothermia and the last one was impaled on a fence. This is considerably fewer than in modern sports, especially as compared with American football, in which 33 players died only in 1908. In Jedburgh, a group of ten-year-old boys said that they had never heard about folk football accidents in this town and only remembered a player having been struck by a car two years before. Still in Jedburgh, the same year, a confirmed player presented the idea of respect and explained during an interview: "I have been doing it since I was a child. There are no rules, old people play and young people have respect for them. It is just common sense"11. Mixing different ages seems a good means to prevent the outbursts, with the older players steering the younger ones. G. Linbin, a long-term player at Hobkirk, a village near Jedburgh, explains this harmony in the game. According to him, people often practise for a long time, even after 70 years old, because this an- 
nual event is their favourite sports activity. It is part of the local social life and almost everybody takes part in it. During the game, people play as much with the ball as with the other people, joking with them as well as trying to provoke them. There are no injuries because the Jedburgh version of the game is very quiet, which enables any suffering player in the scrum to cry out in order to stop the game for a while. ${ }^{12} \mathrm{H}$. Hornby (2008) maintains that violence in folk football is similar to that in any other sport, and that it almost never occurs at the end of the matches. Folk football is more related to pleasure and camaraderie. Anybody trying to escape this spirit of the game is rejected by the group.

In the different places where folk football is practised, the game seems to be very little organised: once the ball is in the scrum, everybody tries to grasp it without minding the other players or using any elaborate technique. Only some occasional actions prove that it is a collective game. Nevertheless, suddenly the game stops and everybody moves aside. The ball is thrown up again and the game begins anew. We learn further on that this unwritten rule applies when a player is in a too difficult position inside the scrum. This rule originates from professional sport, namely rugby. There are very few written rules, which contribute to the game's success. To learn the rules, there is no need to look for them in any official document: it is better to participate, to observe and ask questions. This is what the younger people do during their first matches, trying to imitate the older. They learn to respect their opponents without the help of a referee, and they learn not to trespass into the gardens, private houses, around the churches, railway tracks and main roads. Holt (1990) goes further when he explains that fair play and respect for standards are key features in amateur practices, and that they have been endangered by professionalism in sports from the beginning of the 20th century onwards. This perspective may be idealistic but it nevertheless shows that traditional games knew how to impose respect for the others as well as for the environment during the game, which has not always been the case in modern sports.

\section{SELF-REGULATION OF THE OUTBURSTS}

In the folk football matches, people take care of the children and try to prevent the outbursts. R. Leslie, in Kirkwall, explains that the boys' game is limited between the ages of 7 and 16. During the match, the boys' fathers are around the scrum to regulate the game. In Jedburgh, the boys' game is supervised in a similar way. An older player is there to get out of the scrum any player whose behaviour could be harmful and reminds him: "Play the ba' and not the man." Concerning security issues, special signboards are mounted, which signal the 
cars to go slow. The police are sometimes there, but usually keep a distant eye on the game. To protect the houses and shops nearby, barricades are built up to protect the windows of dwellings and shops, which may be damaged during the game. In Ashbourne and Kirkwall, joiners and glaziers form a committee among the players and repair the damages if necessary, after the match, to prevent the owners from calling their insurance companies or making the repairs themselves. Sometimes, money is collected to finance such reparations. Concerning the general organisation of the games, the local committees launch special events before the matches and raise funds, either to have the balls made or to serve some charitable purposes. Moreover, there is an organisation on a national scale with a special calendar devoted to folk football games all over Britain. ${ }^{13}$

Not only are the games regulated in such an informal way, but their rules also continually change to fulfil the requirements of the modern society and its new standards. In Jedburgh the game changed from football using the feet to hand-played handball. The first rule had already been formulated, prohibiting to strike above the feet, due to broken legs, but this was not enough and was followed by the transformation of football into handball. Moreover, the few cases of drowning often led to changes in the position of the goals, which in the past used to be in the middle of rivers. ${ }^{14}$ Therefore, dozens of players had to fight for the ball in a very risky environment. Even if in some places the game is still played in the water, changing the position of the goals has limited the number of accidents. Concerning more precise regulations, some other examples show that the games can transform and adapt to modernity: Ashbourne, for instance, prohibited the use of motor engines for carrying the ball and ordered games to be finished at $10 \mathrm{pm}$ instead of midnight in order to make the policemen's work easier. In spite of their traditional aspects, the games demonstrate their ability to change, in order to become less risky. Nowadays, some places where no such regulations yet exist think about introducing them. However, some players feel that the games could be under threat, explaining that too much regulation would spoil their pleasure.

\section{UNDERSTANDING OF VIOLENCE TO CONTROL IT BETTER}

Fieldwork on folk football matches thus shows that violence is eliminated at different levels: the fear to see the game being banned in the next years, the fact that everybody knows each other in the game, and the presence of women and children among the spectators has led the players to a lot of self-control in spite of the roughness of the play. Likewise, the promotion and organisation 
of the games are carefully regulated to avoid criticism and fears inspired by the old catharsis theory. Although the practice of folk football is considered to be violent, its performers try to create a positive image for it in order for it not to be condemned. Thus, even if we suppose that determination to maintain the games limits their violence in the present time, it seems possible to imagine that they were not as violent in the past as the historians would say. This shift between the violence of folk football in historical discourses and the lack of violence on the field today leads to several general questions. Does the presentation of a game as violent paradoxically lead to limiting or taming its violence on the field? In other words, is it possible to prevent violence through ritualisation or mythification? And, the other way round, can the high level of regulation in modern sports be analysed as a means of frustration which could indirectly encourage violence, either within the game or outside it?

The data presented here eventually enable us to provide new elements to understand the difficult relations between modern sports and violence. The folk football example, indeed, shows that violence is almost as old as sport itself, and that they have always been connected. In the catharsis theory, the temporary violence allowed by the game paradoxically leads to the renewal and reinforcement of the established order. In European traditional societies, violence occurs in a ritual way at the end of the winter, coming along with the renewal of nature itself. According to cultural anthropologists, games and ritual contests in this season symbolically marked the end of the old year and the beginning of the new one. The British folk football, like the French game of la soule or the Russian Maslenitsa games, was connected with the underlying beliefs which associated the victory of a given team and the prophecy to harvest good crops in the next year. These contests traditionally opposed married men and bachelors in the villages, which symbolised the old and the new year respectively. Ritually organised during the time of the Carnival, more or less encouraged by the clergy and the local nobility, the games were set for the opening of the new year, which until the 16th century coincided with the beginning of Easter. Like in the African "ritual wars" (Gluckman 1963) or in the "flourished war" of the Aztecs (Duverger 1978), the European traditional rural societies performed during their games some fundamental symbolic oppositions between ritual moieties featuring the old and the new, the winter and the summer, the cold season and the hot season, the time of the individual and the time of the collective, and even the evil and the good.

The violence that regularly appears in modern sport and hooliganism can therefore be interpreted as an unconscious restoration of these very old dual cultural schemes, connected in a broad psychological perspective to the youth's universal taste for pride and parade (Muchembled 1989). Deeply anchored in 
the cultural logic of "ludic inversion" (Bakhtine 1970), according to which what is usually forbidden by a given society is exceptionally allowed during its festivals and games, this specific sort of violence needs to be culturally understood rather than really fought against. Without trying to find any excuses for this violence, nor diminishing its danger in a modern society based on rationality and order, it seems better to remember its logic rather to simply condemn it. It is then important to regard it as a means to ritualise dual oppositions within a group, i.e., as an ancestral scheme that manages to last through sport in a new context. Unlike mass violence in wars or free violence in crimes, sport violence can be drawn off and better regulated if we manage to remind ourselves clearly enough that its logic is not serious but has something to do with the game's logic.

\section{NOTES}

1 Ashbourne Royal Shrovetide Football: Ash Wednesday 2008, http://uk.youtube.com/ watch?v=cvkCcCXweOo, last accessed on June 7, 2013.

${ }^{2}$ Kirkwall ba' 2007, http://uk.youtube.com/watch?v=S5_YTSQpIuE, last accessed on June 7, 2013.

3 BBC News: Ba' game legal threat fears, May 9, 2001, http://news.bbc.co.uk/1/hi/ scotland/1320785.stm, last accessed on June 7, 2013.

${ }^{4}$ Document SA 2006-014, Sound Archives, School of Scottish Studies, University of Edinburgh.

5 Ibid.

6 BBC Derby: Ashbourne Shrovetide Football, The Rules of Shrovetide Football, February 6, 2006, http://www.bbc.co.uk/derby/content/articles/2006/02/06/ashbourne_ shrovetide_football_rules_feature.shtml, last accessed on June 7, 2013.

7 Document UD 9 Jethart Ba', Sound Archives, School of Scottish Studies, University of Edinburgh.

8 Document SA 2006-014, Sound Archives, School of Scottish Studies, University of Edinburgh.

9 Document VA 2000-06, Sound Archives, School of Scottish Studies, University of Edinburgh.

${ }^{10}$ BBC News: Streets full for ba' game battles, 15 February 2008, http://news.bbc.co.uk/1/ hi/scotland/south_of_scotland/7246475.stm, last accessed on June 7, 2013.

${ }^{11}$ Interview conducted in Jedburgh, March 9, 2006.

12 Document SA 1989-096, Sound Archives, School of Scottish Studies, University of Edinburgh. 
${ }^{13}$ Calendar available on website http://www.playedinbritain.co.uk/books/uppies-anddownies.php, last accessed on June 7, 2013.

${ }^{14}$ Document UD 9 Jethart Ba', Sound Archives, School of Scottish Studies, University of Edinburgh.

\section{MANUSCRIPT SOURCES}

Interviews and field notes from Scotland and England in the possession of the author: Kirkwall (2006, 2007), Jedburgh (2008, 2012), Ancrum (2008, 2012), Duns (2008), Lilliesleaf (2008), Hobkirk (2008), Denholm (2012), Ashbourne (2009, 2012), Alnwick (2009), Haxey (2012), Workington (2010).

\section{REFERENCES}

Bakhtine, Mihail 1970. L'œuvre de François Rabelais et la culture populaire au MoyenAge et sous la Renaissance. Paris: Gallimard.

Bodin, Dominique 2003. Le hooliganisme, Paris: Presses Universitaires de France.

Bourdieu, Pierre \& Passeron, Jean-Claude 1970. La reproduction. Eléments pour une théorie du système d'enseignement, Paris: Editions de Minuit.

Bromberger, Christian 1995. Le Match de football. Paris: Maison des Sciences de l'Homme.

Burnett, John 2000. Riot, Revelry, and Rout: Sport in Lowland Scotland before 1860. East Linton: Tuckwell Press.

Carnibella, Giovanni \& Fox, Anne \& Fox, Kate \& McCann, Joe \& Marsh, James \& Marsh, Peter 1996. Football violence in Europe: a report to the Amsterdam Group. Oxford: The Social Issues Research Centre. http://www.sirc.org/publik/football_violence. pdf, last accessed on June 6, 2013.

Dunning, Eric \& Sheard, Kenneth 1979. Barbarians, Gentlemen and Players: A Sociological Study of the Development of Rugby Football. Oxford: Martin Robertson.

Duverger, Christian 1978. L'esprit du jeu chez les Aztèques. Mouton \& Paris \& La Haye: EHESS.

Elias, Norbert \& Dunning, Eric 1986. Sport et civilisation. La violence maîtrisée. Paris: Fayard.

Giulianotti, Richard \& Bonney, Norman \& Hepworth, Mike (eds.) 1994. Football, Violence and Social Identity. London \& New York: Routledge.

Gluckman, Max 1963. Order and Rebellion in Tribal Africa. New York: The Free Press of Glencoe.

Holt, Richard 1990. Sport and the British. A Modern History. Oxford: Clarendon Press.

Hornby, Hugh 2008. Uppies and Downies. The Extraordinary Football Games of Britain. Swindon: English Heritage.

Muchembled, Robert 1989. La violence au village (XVe-XVIIe siècles). Bruxelles: Brépols. 


\title{
BETEL NUT, MAGIC AND BASEBALL: A CASE STUDY OF PUYUMA TRIBE IN TAIWAN
}

\author{
Junwei Yu
}

\begin{abstract}
Despite considerable research being done on Taiwanese aborigines and baseball, no study has been undertaken on magic and baseball in regard to specific indigenous ethnic groups. This article examines the extent to which betel nuts were used as a vehicle for the expression of human relationships with the supernatural in baseball. The Puyuma, renowned for practicing black magic, have always been accused, in particular, by the Amis, of casting evil spells on the ballpark to achieve their own ends, such as winning. Empirical materials have been drawn from fieldwork in Taidong, where in-depth interviews were conducted with coaches and players from the Amis, Puyuma, Bunun and Han Chinese groups. Additional sporadic secondary sources have also been drawn on. The author argues that in spite of the discovery of betel nuts buried in the ballpark, there is no solid evidence of malicious intent by the Puyuma. Moreover, the betel-nut-spell practice corresponds with the intellectualist perspective that magic has gradually died out, since it contradicts the basic principle of baseball, namely, scientific training.
\end{abstract}

Keywords: Puyuma, baseball, betel nuts, black magic, Amis

\section{INTRODUCTION}

Generally speaking, people do not make connections between betel nuts, magic and baseball. This essay argues that the Puyuma tribe indubitably applies its folk religion to baseball, and produces a unique sports phenomenon. I was intrigued by this topic because of a research trip to Taidong, a place that has the highest percentage and largest group of aborigines in the population, during the winter break in 2010. While on this trip, I talked about the baseball performances of different tribes through casual chats with baseball people there. For example, the Amis, who have whiter skin and tall stature, are born with tremendous athleticism, while the Bunun, Paiwan, and Rukai have darker skin, and have shorter but burlier bodies. As to the Puyuma, they allegedly use magic or witchcraft on the sport fields in a malicious intent towards their 
opponent. It is the mysterious nature of betel-nut-spell practice that triggered my interest in this research.

There are three principle types of theory that explain the occurrence and the functions of magic; these are intellectualist, structural functionalist and psychological. The intellectualist perspective (or evolutionism) suggests that cultural evolution was a universal, linear process from "savagery" to "civilisation", during which magic was merely a transitional stage to religion and, ultimately, to science. Tylor (1871) thought that magic was logical, but based on a false reasoning of the natural world. Frazer (1948) furthered Tylor's theoretical framework by proposing two basic principles in magical thought, one being that like produces like and that an effect resembles its cause, and the other that things formerly in contact continue to act on one another. The structural-functional model is based on the assumption that social institutions are best understood in terms of their functions. Accordingly, Radcliffe-Brown (1948) suggested that the functions of magic and ritual are to support group collaboration and interdependence. The psychological school (or functionalism) is represented by Malinowski (1935), who argued that magic has the value of reducing people's anxiety, thereby enabling them to deal with uncertainties in the environment.

Considerable research has been done on aborigines in Taiwanese baseball, either from the historical (Wang 1994; Gao 1995a, 1995b; Yu 2007a; Yu 2007b; Zhang 2007; Yu \& Bairner 2010) or sociological point of view (Qiu 2003; Qiu 2008; Lin \& Zhu 2009), since the miniscule 2 percent of indigenous populations accounts for over 40 percent of players in the domestic professional league. However, there has not yet been any anthropological study done on folk religion and baseball, concerning specific aboriginal groups. In western scholarship, extensive research has been conducted on superstitions, magic, and rituals associated with professional baseball (Gmelch 1971, 1992) and college baseball (Ciborowski 1997), while Bradley and Gordon (2007, 2010) have explored the supernatural rumours and stories surrounding professional baseball and ballparks. Burger and Lynn (2005) compared the superstitious behaviours of American and Japanese players. In terms of magic, Gmelch suggested "that unlike many forms of primitive magic, baseball magic is usually performed to achieve one's own end and not to block someone else's" (2009: 6) - a statement standing in stark contrast to Puyuma's "black magic".

The author conducted two research trips to Taidong, where the Puyuma aboriginal group used betel nuts on the baseball field, in order to collect empirical data. To understand this cultural phenomenon, the techniques involved ranged from archival research to observations, such as participant observation, through to interviews. In total, the author carried out eleven face-to-face semi-structured interviews, with four coaches, three retired players, three active players, and 
one retired school principal. Moreover, one telephone semi-structured interview was made with an active player. Apart from the retired principal and one active player, who were Han Chinese, the others had aboriginal origin, either from Amis, Puyuma, or Bunun. Each one-on-one interview usually lasted about an hour, and was audio recorded. The author also went to a palakuan (men's meeting hall for the Puyuma tribe), to take part in a traditional ceremony, for which a shaman and his assistant had prepared betel nuts.

\section{BRIEF DESCRIPTION OF TAIWANESE ABORIGINES}

In Taiwan, the word 'aborigines' refers to the earliest groups of people arriving in the island and inhabiting it before the Han Chinese, who systematically started to migrate from mainland China to Taiwan only in the seventeenth century. Although there have been several theories relating to the origin of the Taiwanese indigenous populations, research in the fields of linguistics, archaeology and anthropology in recent years has suggested that their ancestors may have been living on the island for approximately 6,000 years before the arrival of large Chinese settlers. According to classifications available in genetics and linguistics, Taiwanese Aborigines belong to the Austronesian group, which is strongly associated with ethnic groups in the South Pacific islands, such as the Philippines, Malaysia, Indonesia, Madagascar and Oceania, amongst other regions. Some linguists have considered Taiwanese to be the origin of Austronesian languages, which makes these native languages carry great historical significance (Blust 1985; Bellwood 1991).

In the early days, Taiwanese aborigines lived in the "frontier" of the territory of China and were viewed as "non-Han Chinese", who were lower in cultural level and irrational in religion and behaviour. In Chinese recorded documents - dossiers and local chronicles - aborigines in Taiwan were referred to as "East Savages" or "Wild Barbarians" (Eastern Savages). In the Qing Dynasty, they were called "East Barbarians", "Wild Barbarians", "Raw Barbarians", "Semi-subdued Barbarians" or "Cooked Barbarians", according to their "level of civilization assimilated to the Han cultural norms". During the Japanese colonial period, Taiwanese aborigines were referred to as a "Barbarian Group" or "Takasagozoku". After the Chinese restoration, the government generally referred to aborigines as "Shanbao" (the mountain compatriots), divided into "Shandi Shanbao" (mountain aborigines) and "Pingdi Shanbao" (plains aborigines) (Wang 2001). It was not until 1994 that they were officially called aborigines. The Ministry of the Interior lists 14 groups as aboriginal tribes, these being the Amis, Bunun, Paiwan, Tsou, Rukai, Puyuma, Saisiyat, Tao, 
Atayal, Thao, Kavalan, Truku, Sakizaya and Seediq. As of June 2010, the total population of Taiwanese Aborigines is 508,380 (approximately 2.1\% of Taiwan's population), and the bulk of contemporary Taiwanese Aborigines reside either in the cities or in the mountains (Ministry of Interior 2010).

Although according to social culture, all Taiwanese aborigines are classified into Malayo-Polynesian system, there remain huge differences between various tribes. For instance, in terms of governance structure, Tao and Bunun are egalitarian societies, while Rukai and Paiwan apply the caste system, separating people into aristocracy and commoners. In terms of religion, the range is from wizard faith without specific form to polytheism. As for family organisation, this varies from patriarchal and matriarchal to double descent society. These tribes, of which there are more than a dozen, demonstrate a huge variety of socio-cultural phenomena.

Taiwan's aborigines have adapted themselves to the ecological environment of the island whilst retaining their particular socio-cultural systems. Moreover, they have also had to endure outside forces - politically, economically, and religiously - and seek to survive in the gap between the maintenance of tradition and ongoing modern transformation. Generally speaking, the socio-cultural system of the Taiwanese aborigines has undergone four transitional stages. First was the period of traditional tribal life; second - the period of Dutch and Qing rule, in which different cultures began to merge; and third - the 51 years of Japanese colonial rule, which completely incorporated the aborigines into the modern state system for the first time. Lastly, the arrival of the KMT (Chinese Nationalist Party) in 1945 witnessed the introduction of pan-Chinese education and ideology, accompanied by a mass exodus of tribal members from their traditional lands, causing a massive crisis in aboriginal culture.

The Japanese colonial government and the later KMT regime systematically and purposely exercised an assimilationist policy toward aborigines in the areas of language and culture, and also penetrated deeply into the tribes through trading and intermarriage, amongst other activities. This caused a huge evaporation of native languages and tribal identity. For example, ten out of approximately twenty-six languages of the Taiwanese Aborigines (known as Taiwan Austronesian languages) have already disappeared, with five of them being on the verge of disappearance, while many other languages have experienced certain levels of damage (Zeitoun \& Yu 2005). 


\section{THE PUYUMA, BETEL NUT AND MAGIC}

In comparison with the population as a whole, Puyuma is a small tribe with approximately ten thousand people. Their habitat covers the eastern side of the Central Mountains, the coastal area of the southern part of the Puyuma River, and the mountain area of the southern East Rift Valley. Puyuma are a very doughty people, whose major inhabitation is in Taidong County. During the Qing Dynasty, they formed eight communities, and made glorious history in the 17th century. In Kangxi and Qianlong period, Beinan, the principal tribe of Puyuma, defeated the remnants of the Zhu Yigui and Lin Shuangwen rebels, respectively. Their chief was granted the court dress and bestowed the title of "The Great Lord Puyuma" (Historical Records 1963; Song 1998). The Puyuma people possessed strong military prowess because all males would undertake a training system known as palakuan.

Puyuma is a matrilineal society that applies uxorilocal marriage. However, this tradition has inevitably had to adjust with the passage of time. To take marriage as an example, now most of them follow the patriarchal principle that women marry into men's families, and children take their father's last name, while in some families half of the children take the mother's name (Song 1998; Temporary Committee 2000). In Puyuma society, there are two key leading persons - one is a male priest, who takes charge of major tribal rites; the other is the political head, a role that is often taken by someone with strong leadership ability in the tribe, who is able to take the responsibility as the mediator of major tribal affairs, and as the leader of hunting, rites and battles. Nowadays, the male priest still remains in his traditional job, and is respected by the tribe, but the position of the political head is different, and can be affected by interference from the modern governmental system (Song 1965; Wei 1965).

The most famous cultural figure is that of the Puyuma shaman, known as bulingow in Zhiben dialect, and tamaramau in the Nanwang tribe. All the neighbouring aborigines are fearful of their magic power, since they are renowned for witchcraft. The shamans - a position usually held by women - have the ability to divine, cast spells and dominate rites, while the wizards often work as bamboo divinators, something that might have been learned from the Amis. Witches and wizards hold an esteemed position in society, so it has become a custom for specific Puyuma women to learn witchcraft in early days, and go through the ordinary procedures of magic learning. A shaman performs a wide range of functions, mainly in regard to healing the sick, dispelling evil spirits and praying for blessings, but also assisting people in searching for lost property and livestock, and dispelling misfortune or calling the spirits (Cauquelin 2004). 
Nowadays, the tribe still preserves their traditional shaman for helping with illnesses, dispelling evil spirits and executing the customs and ceremonies of significant life events. It should be noted that magic further divides into white magic and black magic. The former focuses on healing the sick in order to drive out the misfortune, while the latter, rarely exercised unless necessary, is used to cast spells upon people for evil intentions (Tian 2002).

The betel nut is famously known as a key medium and sacrifice of Puyuma witchcraft and various rites. Without it, people would have lost the means to communicate with the ancestral spirits. The term palisian means "casting a spell or performing rites", which is called salisin by the Amis. ${ }^{1}$ In the early days, when people confronted unfair matters and had no strict laws to follow, the function of casting spells came into existence. In particular, during the time when battles often occurred between tribes, Puyuma witchcraft worked as a means of putting evil spells on the enemy and counteracting or diminishing the opponent's magic power. This function was popular once in the past. Now, only the aged shamans possess this mysterious skill, and it is rare for people to perform such black magic. There are two ways to explain the symbol and function of a betel nut. First, an intact betel nut without any cutting represents the fact that the ancestral spirits have not yet been requested. Second, three betel nuts split open with string-tied pottery beads, or with iron slices inserted into it, represent the fact that the ancestral spirits have already been requested. The Puyuma take the shape of the betel nut to symbolise a person, with the stalk tip as the human head and the fruit as the human body. They cast a spell upon part of the target person, and the power of the spell will be enhanced if the betel nut is inserted with pottery beads or iron slices (Zeng 2009; Baisu 2010).

As to the Amis society, the largest aboriginal group in Taidong, they also have their magic practices. The term kawas refers to all the spirits of heaven and earth and also the deities, souls, ghosts and demons. Many tribes would ask for guidance from kawas through cikawasay (wizards), who may use methods as varied as dreams, bird divination or 'edaw (bamboo divination). The wizards perform 'edaw by stepping on the middle of a slim bamboo branch and dragging both ends of it. They can tell the fortune according to the shape of the cracking gap. The Amis enquire into matters through bamboo divination, and then follow the divining result to dispel evil spirits, heal illness or resolve confusion. However, the Amis practise the ritual for their own benefit, rather than for harmful intention (Yang 2003; Lin 2005). 


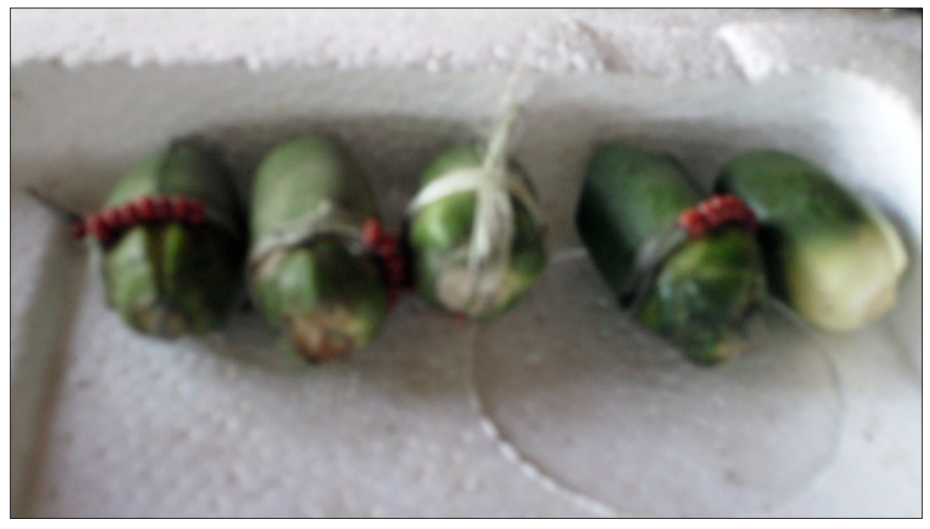

Figure 1. Each betel nut represents an evil spirit. From right to left as follows: natural death, unnatural death, bad thing, gossip, and jealousy. Photo by the author 2010.

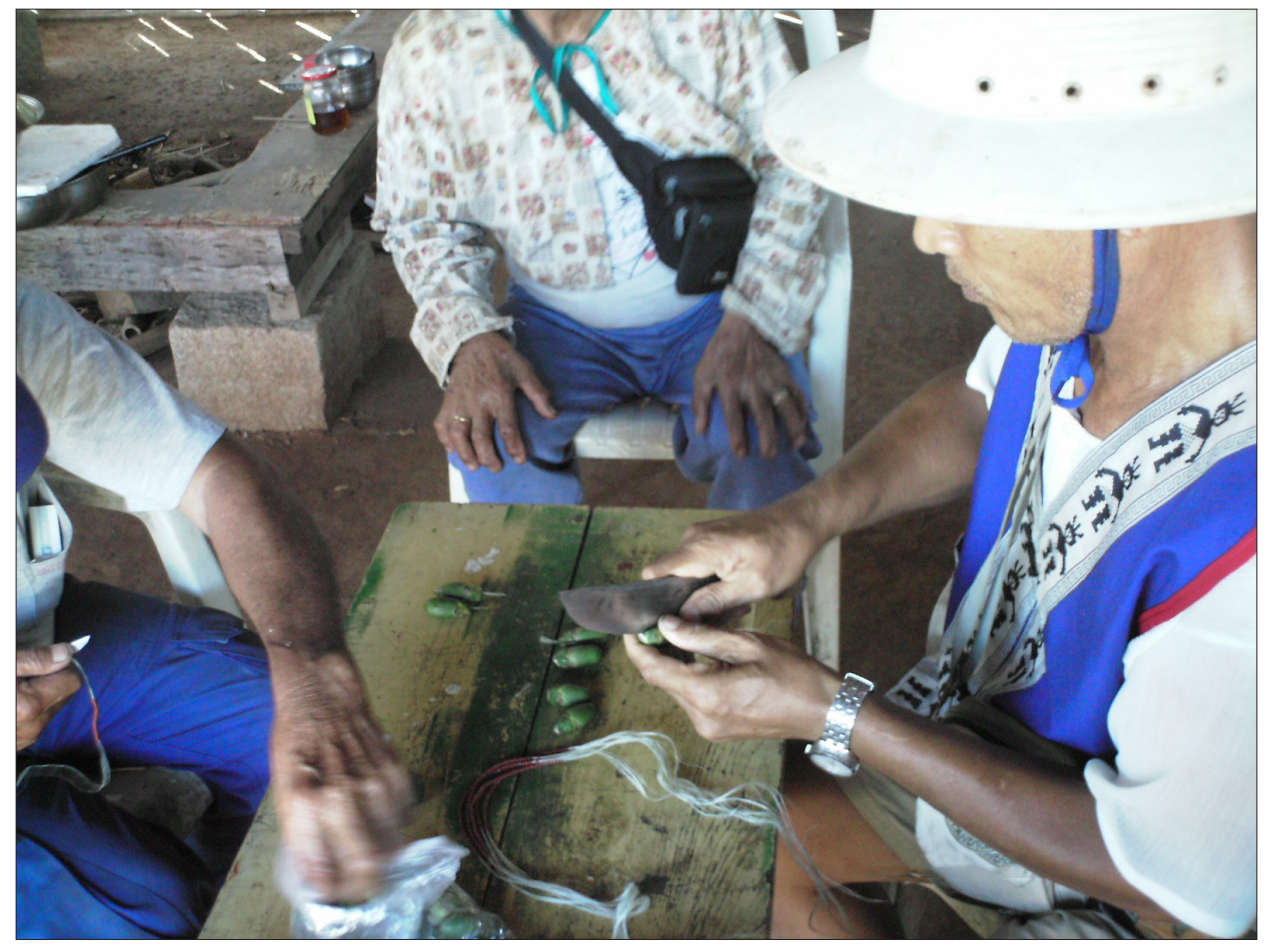

Figure 2. A wizard and his assistant are making a betel nut spell in the palakuan. Photo by the author 2010. 


\section{HONGYE BASEBALL TEAM - VICTIMS OF PUYUMA WITCHCRAFT?}

The aborigines' connection with baseball dates back to the Japanese colonial period, during which the first all-Amis baseball team was formed in 1921, in an attempt to divert their violent barbarism into civilised sport (Xie \& Xie 2003; Yu \& Zeng 2004; Yu et al. 2006). This was followed by the famous Jianong baseball team, comprising several key indigenous players, who took the team to runner-up status in the 1931 Koshien finals held in Japan (Zeng 2001; Lin \& Lin 2005). After the KMT came to Taiwan, Taidong's baseball continued to thrive under the tutelage of Jianong alumni, most of whom were Amis, coupled with a few Puyuma. This is the major reason why currently the Amis constitute such a high percentage in Taiwanese baseball, whether professional or at the grassroots level. Despite a long and rich history of baseball involvement, the importance of folk religion, such as Puyuma's betel nut spell, which might have been applied on baseball, is largely ignored in Taiwan's scholarship.

The book edited by Zhang Jingguo (1983) might be the first print media that recorded baseball and witchcraft. Strangely, however, the specific article that featured the controversial incident did not have any author, thus making it hard to trace the origin. It mentioned the legendary stories of Hongye Little League, who won against Japan Kansai all-star team in 1968. The public dubbed Hongye players as kids who practiced "with wooden sticks as bats and rocks as balls", which touched every person in the island. They lived in such a Cinderella tale that some even claimed that Hongye was the starting point of Taiwanese baseball. However, in the story the author was more intrigued by their altercation over black magic with the Puyuma.

The scene was set in the Hongye village inhabited by the Bunun, with the Puyuma being down from this village. Before the KMT came to Taiwan, the two tribes had their own territory, and had many battles, in which they demonstrated serious hatred against each other. They even had the custom of hunting the opponent's head (Kasahara 2009). It was not until Puyuma chief Ma Zhili successfully brokered a truce between his people and the Bunun in 1939 that the two centuries of mutual killings ended. Though there was still a grudge, after generations under the suppression of Japanese rule, the two tribes had a more forgiving attitude, and are no longer engaged in hostilities as was the case with their ancestors (Sun 2001).

Lin Zhupeng worked as Director of Teaching Affairs in Beinan Elementary School, dominated by Puyuma kids, for ten years before becoming Principal of Hongye Elementary School. He started a baseball team in Hongye to attract students to school, and at the same time, prevent them from truancy. Lin then 
brought the children down from the mountains to play friendly games with Beinan in 1963. However, many Hongye kids started to have diarrhoea. Parents were concerned that the suspected cause was the evil spell from the Puyuma during ball games. As a result, parents disallowed their children from playing baseball and going down for the competition. This placed Principal Lin in a difficult situation, though he tried his best to explain to parents that in this modern time with advanced scientific knowledge, witchcraft or spells were not real. Unfortunately, the Hongye villagers did not take Lin's advice, and training was suspended in less than two months after the team was formed.

To find out the real cause of the problem, Principal Lin invited Cai Wenshui, the chief doctor from the health station of Yenping Township, to do a health check for all the team members. The result showed that diarrhoea was caused by the roundworm and hookworm. He not only asked Cai to help to provide medicine to the students immediately, but also bought flour to make buns, whilst offering nutriments to them. Due to his hard work, the students gradually recovered from the illness and became healthy. Parents would not cast doubt on the mysterious power. Ultimately, with everyone's approval, the team resumed training, and all the players were vigorous. Because of this event, the Bunun and the Puyuma finally erased their grudge, and the Hongye team began its period of glory.

This story is the only written record of baseball and witchcraft. Though no betel nut was mentioned in terms of performing black magic, it vividly demonstrated how fearful the Bunun were towards the Puyuma, especially when bad things occurred. When asked about this event, Lin replied:

They were suspicious of their plot, but I strongly insisted that it was not witchcraft. If they really did want to cast a spell, why not cast it on me, the principal. If I were gone, Hongye could not have continued anymore. It was only because of the roundworms. (Personal communication, August 14, 2010)

As a result, students were sent to a Puyuma doctor, who the parents thought of as being from the evil party, to have a comprehensive health check, and they quickly recovered. Although the reporter claimed that team training was halted due to witchcraft, this was not true. The team carried on their training schedule without being affected by the incident. It is assumed that the journalist dramatically exaggerated this event to achieve higher sales.

According to Hu Meiyun, a first generation Hongye player, "the Bunun and Puyuma indeed had some conflicts over the occupied territory, and both peoples had the custom of hunting each other's heads". As to casting a spell on the Hongye baseball team, he stated: 
I have not heard about it. I think it was because of the poor sanitary conditions at that time; so many people got an infection which caused either illness or diarrhoea. It happened when we lost to Beinan, so parents started to blame it on witchcraft. It was a coincidence. (Personal communication, August 9, 2010)

However, Hu also agreed with the viewpoint of other tribes that Puyuma witchcraft was famous, and, therefore, if he saw betel nuts on his way, he dared not pick them up, and made a detour instead.

\section{PERSONAL EXPERIENCES WITH BETEL NUT AND BASEBALL BEFORE 1972}

In interviewing the Amis coaches, the author found that they unanimously agreed upon the wicked, yet unbelievable, magic power of betel nuts in their childhood. As Guo Zixiong, a retired Amis coach, remembers:

They love to use betel nuts with beads inserted, and then put them there... I don't really understand, I saw a lot of this in my childhood and on the curbs of roads. It was strange, and we were afraid. We did not dare to walk over the nuts; instead, we took a bypass. (Personal communication, February 2, 2010)

A senior baseball player, Gao Kewu, also said, "We were very naïve when we were small, and always thought if people were sick, we should go for a Puyuma witch for healing them" (personal communication, August 9, 2010). This is the typical stereotype of Puyuma witchcraft projected by the Amis people.

A former baseball player, Chen Mingtian, also had unforgettable experience about witchcraft in baseball:

I was playing baseball barefoot in my elementary school time. I made a hit and ran across the bases but sprained [my foot] because of the poor field. My big toe swelled badly, even if I applied ginger on it or a hot compress. Till the third day, I was so much in pain that my mother went for a relative, a Puyuma witch. She started her witchcraft by setting six fresh betel nuts on the ground and began her incantation. She walked into the river, and when walking back, she was breathless and sweating badly. Suddenly, a thing dropped - a dried flat betel nut with beads and a needle in it. It was because she had fought with the evil figure setting up the poisonous spell and finally she defeated it. The next day, my 
swollen toe was cured without taking any pill. (Personal communication, February 3, 2010)

As for the baseball games themselves, it was not until the late 1960s that betel nuts were found in the field. In the 1960s and 1970s, Beinan and Xinsheng Junior High Schools were in close proximity to each other, and in fierce rivalry for district supremacy. The former is located in Beinan area, and therefore had more Puyuma players; the latter is located in Taidong City and had more Amis players. ${ }^{2}$ Chen Mingtian, a former player from Beinan Junior High School, recalled one curious incident:

Our coach asked us to clean up the field before next day's competition. When we took off the home plate to draw lines, we saw betel nuts, about four or five; they were fresh, not dry at all. We stripped the nuts and found three beads and a needle inside. Also, we found more betel nuts under the pitcher's mound. Damn it! Some of the aborigines said this was salisin. They started cursing and threw the betel nuts into the bush without telling the coach and others, to make them believe the betel nuts were still in the field. Because our opponent was Xinsheng Junior High School and the field was so close to them. Moreover, their coach's wife was a Puyuma, so we assumed that they were the culprits for putting the betel nuts there. (Personal communication, February 3, 2010)

However, Wang Jincheng, the coach of the Xinsheng team, provided conflicting statements as to who was responsible for burying betel nuts. He mentioned that every time when they played with Beinan Junior High School, whose Puyuma players accounted for higher percentage, especially in important competitions, they found betel nuts. Therefore, Xinsheng players always arrived on the field thirty minutes earlier, with the purpose of cleaning the field, but in reality they were going to dig out all the betel nuts that might have been buried there. They did this because the parents of players told them to avoid injury (personal communication, August 13, 2010). In their view, the betel nuts represented evil intentions towards people. As distinct from other respondents, who only saw this for a few times, coach Wang had seen this all the way from junior high to senior high in his playing career, especially in regional competitions that involved Puyuma players or coaches in the opponent team.

The Amis player, Yang Jieren, recalled that when they participated in the Taidong Little League Competition in 1972, they lost the game to a team including several Puyuma players. Parents said the match was cursed and later took off the bases to see if there was foul play. Indeed, they found betel nuts under every base (first base, second base, third base, and home plate) as well as the pitcher's mound. At that time, the bases were not located permanently 
on the ground but only fixed by two nails. ${ }^{3}$ People who buried betel nuts must have spent time pulling out the nails and then digging holes to put the nuts in. Since they found the betel nuts after the game, the nuts were all dried out and had beads strung with a thread inside. At the time, Yang and his teammates really believed that they had lost the game because of black magic, and cried out loudly (personal communication, August 12, 2010).

\section{BEINAN JUNIOR HIGH SCHOOL BASEBALL TEAM IN 1994}

The betel nut spell seemed to vanish from 1972 to 1994 . One major reason is the player exodus, due to which many Taidong players went out to play for other cities or counties, thus leading to the dissolution of local teams. As long as there was no team playing in Taidong, the betel nut spell would not appear. But in 1990, the CPBL (Chinese Professional Baseball League) was established, offering a future for grassroots players. At the same time, the Ministry of Education launched the student baseball league, in which players were not allowed to play for the city or county other than their hometown. In addition, Nanwang Elementary School won the champion of Chinese Cup Youth Baseball Tournament, and all the graduates attended Beinan Junior High School. Puyuma coaches, Chen Zhixiong and Chen Fubin, from Nanwan, were hired to provide coherent training for the players. In 1994, these Taidong players finally bore fruit in the National PONY (Protect Our Nation's Youths, aged 13-14) League Qualifying Tournament, in which Beinan and Xinsheng Junior High Schools won the champion and the second place respectively, becoming the first national team in middle school level to come from Taidong since 1945. Beinan represented Taiwan to win the PONY Asia-Pacific Qualifying Championship, and subsequently went on clinching the PONY World Series in Washington, Pennsylvania, in the United States.

Competitions between the two Taidong teams of Beinan and Xinsheng Junior High Schools were often tense, to say the least. As such, both sides called for help from mysterious powers, which was a unique phenomenon. Xinsheng had Amis players from the coastal area, who had better stature. They were viewed as the superior team, especially since they had the tall, six-foot Amis pitcher Chen Yuanjia. Beinan's players were mostly from the mountains; their stature was not as good as that of the Xinsheng players. However, they were also welltrained. In May 1994, Xinsheng clinched the championship, while Beinan only attained third place in the National Under-15 Rubber Baseball Tournament. But the most important competition was the PONY League Qualifying Tournament held in Taichung, where a double-elimination system was used. Xinsheng were 
seen as the favourites to win the competition; surprisingly, they lost to Beinan in the first game. As a result, they went for a repechage, and had to fight their way back, beating the opponents one by one until they ultimately met Beinan in the finals. Xinsheng's parents started to question whether the curse was the cause of their failure, particularly when they saw a Puyuma witch on the stand. As Guo Zixiong, the coach of Beinan, recalled:

As soon as Xinsheng lost [the first match], they started to blame on the spell from Puyuma. The Xinsheng coach's wife was from Nanwan, Puyuma, so he insisted there was mysterious power involved. [In the final], the first base referee asked why the aborigines had brought two god statues on the spectator stand. I was also shocked by seeing this. Those statues of Taoist gods were brought by parents from Xinsheng to counteract the Puyuma witchcraft. After the game finished, I went to the entrance asking those parents why they had brought this stuff to the field. It did not make sense! Later, back in Taidong, I asked them again why they had brought two god statues, for what? For worshipping their gods on the field or for some spiritual ceremony? They replied it was all because the Puyuma people loved using salisin. I burst out laughing ... I told them it was their tradition, but not mine. I told them that they needed to bring a god who could play baseball. The gods they had brought along did not know about baseball, so how could they win the game (laughing wildly). (Personal communication, February 2, 2010)

From the above passage, we can see the transformation of worship beliefs among the Amis, who changed from animism to Taoism as a consequence of rapid Han Chinese assimilation. Most people in the Malan tribe, one of the biggest Amis gatherings in Taidong, had converted to Taoism. Not surprisingly, several Xinsheng parents were willing to bring the prosperity-dispersing Queen Mother of the West (Xi Wangmu) to suppress Puyuma witchcraft, which had become a common topic of chitchat among the locals. ${ }^{4}$ Lu Guanchang, a Xinsheng player, recalled that the Goddess was placed on a deity table, from which incense worship started at the entrance of the dugout facing the opponent team, and was later moved to the stand. He jokingly said that the statue arrived a bit late for the game. Therefore she could not perform the mighty power from the very beginning, and they lost the game to Beinan 0-7 (personal communication, August 28, 2010).

The Queen of the West-versus-Puyuma witchcraft showdown created a hangover that lingered for over a year. ${ }^{5}$ Parents from both sides made accusations against each other, even to the level of committing sacrilege to the opponent's gods. This event was also in the newspapers and later hindered an organised 
effort to form a Taidong all-star team for the IBAF (International Baseball Federation) Under-16 Tournament in 1995. ${ }^{6}$ Neither side would make a concession to the other; therefore, the County Government came out to mediate in order to merge both sides into a dream team, which clinched the national championship later on. Ironically, players from both sides graduated one year later, and entered the same high school, Taidong Sports High School. The grudge between them gradually diminished.

During the PONY Asia-Pacific Qualifying Championship in Japan and PONY World Series in the United States, both Puyuma coaches brought betel nuts on their trips overseas. Officially, a betel nut cannot be carried abroad. It appears that the coaches paid lip services to the regulations. They divided the nuts into five parts and let students carry them separately, thus passing the customs inspection. "We were afraid when inserting those betel nuts into our luggage, for in the States, they had police dogs to smell and search for the contraband. Luckily, we passed all examinations", Gao Wei remembered (personal communication, August 3, 2010). It appears that betel nuts were not only something to be chewed, but could also be used for ball games. Before the team took off, all the betel nuts were sent to the witches, who cast spells upon them so as to endow them with magic powers, which enabled them to function in Japan and the United States.

The Amis coach, Guo Zixiong, did not believe in the magic power of betel nuts as being able to contribute to the performance of the team. But he was deeply convinced that the Puyuma coaches in the same team continued resorting to the enchanted betel nuts, carrying them to America, and burying the objects in the ballpark:

I was joking to the Puyuma coach asking if their god would travel with us all the way to the States. He answered he had already called back home to ask the witch and confirmed that to do so the magic power would still work. I could have set my face against this, but I chose to respect them. I just said it was good to have help even from gods. When they buried those betel nuts, those Americans certainly didn't know what they were doing. They pretended as if they were practicing but actually let students and pitchers go digging holes to put the nuts in. You just put them there, and who would know. So the magic power seemed to go with us to the States and help Beinan win the World Series. (Personal communication, February 2, 2010)

Although the Amis coach asserted that Puyuma coaches did execute the mysterious spell by burying betel nuts under the pitcher's mound and batter's box, this was denied by Beinan pitchers Gao Wei and Luo Jianming. They said their 


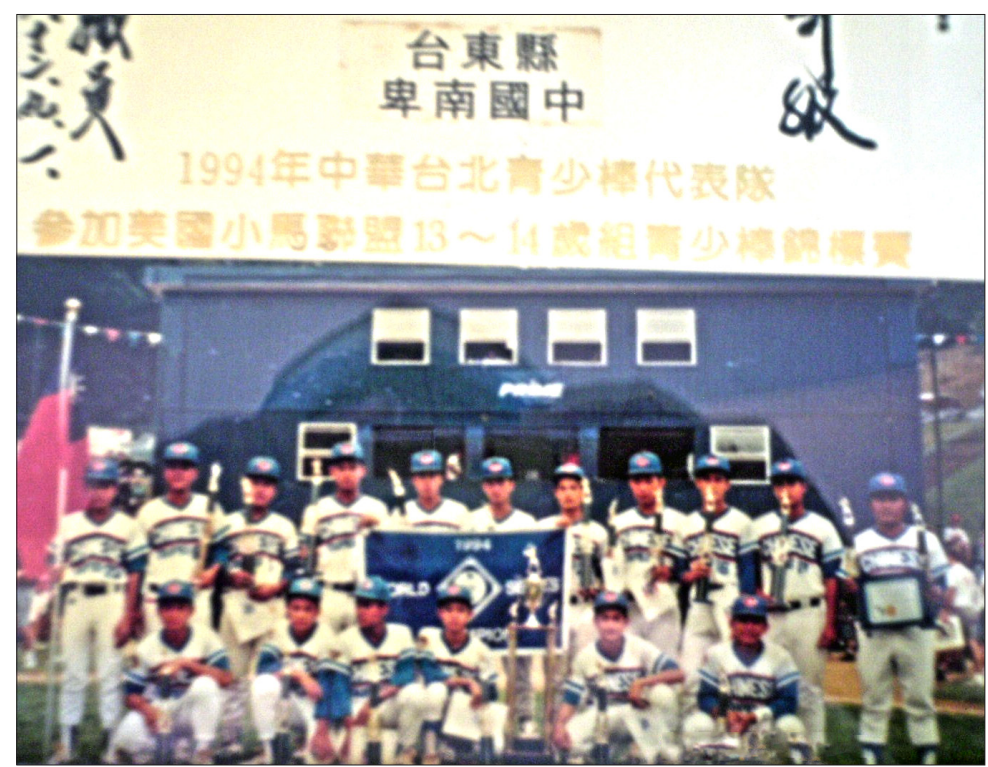

Figure 3. Beinan Junior High School won the 1994 PONY World Series in Washington, Pennsylvania, United States. Photo by the author 2010.

coaches did bring betel nuts to the States, but they buried them outside of the dugout to let players walk across, merely for good luck. They did this to pray in a positive way, but not for cursing or calling up evil spirits. So it might have been because the Amis coach was over-educated about the Puyuma witchcraft, and had a stereotypical view of the Puyuma, who must have won the game by means of the spell. It may be that the Puyuma coaches did secretly set up the betel nuts spell, but this was never discovered by others.

\section{COACHES AND PLAYERS' RESPONSE TO MAGIC}

Recently, betel nut spells have been rarely mentioned, and young players do not find them buried in the field. However, betel nuts can still be used as a medium to pray for good luck. Tian Zhijia, a Puyuma player once playing for Zhongdao High School, mentioned that their head coach was also a Puyuma. Therefore, there was always a dried betel nut attached to their team flag. If the game was tight, especially when the team fell behind in the 7th inning, the head coach would start to mumble aboriginal spells toward the flag. 
He looked so serious that no one dared to bother him. Not a single person had the slightest idea of what he was mumbling about, but strangely enough, the game would end up with a draw, and sometimes a win! (Personal communication, August 4, 2010)

An interesting thing was that the ten-year Zhongdao team was often knocked out during the early group stage in virtually every national competition, despite calling for blessings from "ancestral spirits".

All the Amis coaches, both in the past and nowadays, refute the effect of betel nuts, and regard this as nonsense that has no scientific backing. Due to repeated inculcation of dreadful Puyuma witchcraft by their forefathers, most Amis think that burying betel nuts must be evil, with the negative intention of making the opponent injured or not able to hit well, instead of the common practice of praying for good luck. During the 1960s and 1970s, the Malan Baseball Team composed of only Amis players had its own fixed rite before setting off for the game. The male elder started the rite by reading the Amis curse to call up their ancestral spirits to help their offspring be safe in the game. Then, he would hold rice wine inside his mouth and spray it on the players and the baseball equipment. This rite is performed to pray for blessing rather than evil intention. Other than this, there was bamboo divination. An Amis elder would step on the middle of a slim bamboo branch and drag both ends of it so that he could tell the team's future performance, according to the shape of the cracking gap. Ironically, the retired Malan player Chen Mingtian did not believe in his own people's bamboo divination, but thought the Puyuma rite to be more effective.

Yang Jieren recalls that betel nuts actually had no power over the result of the games. "If they had, the games would not have gone so smoothly, and besides, no players were hurt during the game" (personal communication, August 12, 2010). But they were really upset about losing the vital game, crying so badly and really thinking the betel nuts messed up the match outcome. Chen Mingtian also remembered that "Beinan and Xinsheng both had their winning and losing time, but no one was hurt, so nothing was really influenced by magic. Losing is losing; no one threw the game away deliberately" (personal communication, February 3, 2010). Meanwhile, Wang Jincheng dismissed the Puyuma witchcraft with contempt, saying that "though the magic may only succeed once in ten times, everyone would remember the successful one" (personal communication, August 13, 2010). Even the 18-year-old Puyuma player Chen Zhenghao made a similar statement while playing for Nanwang youth baseball team:

The witch would talk to us first in Mandarin, which was very fluent. She said the ancestral spirit of Beinan would bless and protect us in our 
baseball games. Then she asked us to walk to an open ground, and placed some sand on the grass, and put betel nuts on it. Three nuts on one side, so both sides together had six. She also inserted beads into them. Then she made us stand in front of the nuts and spoke to us. However, we still lost games. I think that rite was only for mental calmness, nothing more. (Personal communication, February 5, 2010)

In interviewing coaches and players, I discovered that the Han people did not really believe or know about Puyuma witchcraft. Like Lin Zhupeng and Fu Qingshun, the key figures for promoting school baseball of Taidong and the former school principals, did not know it at all. Guo Guicai, the coach and a Taoism follower, did not believe it, either. After all, the Han people have little connection with the Puyuma, so they display little wariness of witchcraft when compared to other aboriginal groups. A parent from Puyuma indicated that even in the modern age, the neighbouring tribes of Paiwan and Rukai people are still hesitant about making friends with them, owing to this historical reason.

However, until today, no Puyuma coaches would admit burying betel nuts, either because using black magic was nothing to be proud of, or it was not the coaches who pulled such a stunt. Some people think it was the victory-obsessed parents who may have had recourse to the nuts. In fact, winning a baseball game is based on science and training. If a coach did something against this principle, it would certainly backfire once the results did not go their way. As a Puyuma coach said, "If witchcraft does have such a powerful effect, then players don't have to practice anymore; all they need is burying betel nuts for the results".

Moreover, the lower the education that people receive, the more they tend to believe in magic. Taiwan did not adopt nine-year compulsory education system until 1968; therefore most aboriginal parents only received elementary school education when the betel nut incident occurred. Their eagerness for national champions that brought fame and prospects of playing abroad was very strong, considering the poor and marginalised state of Taidong County. On the contrary, people with a higher educational background are inclined to see magic as a baseless pseudo-science, which has no place in baseball. For instance, the legendary Puyuma player Chen Gengyuan educated during Japanese colonialism was never heard approving this kind of cultural practice. One thing for sure is that Puyuma coaches would invite a wizard or a witch to be a spiritual leader wearing aborigines' traditional outfit and praying for the team. Nevertheless, this kind of practice has also diminished dramatically. 


\section{CONCLUSION}

To Puyuma people, the betel nut is a seed that creates a chewing tobacco-like buzz, but also a tool of worship in their traditional rites. It is more important than rice wine because it acts as a medium that communicates with ancestors and gods. This article has sought to analyse the symbolic meaning and cultural practice of betel nut spell on baseball from the viewpoint of cultural anthropology, through empirical data collected within fieldwork and existing secondary materials. For historical reasons, different groups of people have different interpretations of cultural symbols. For example, all Amis think that the burial of betel nuts is motivated by malicious intentions, instead of good blessings. In addition, they assert that betel nuts must come with Puyuma people, who cast evil spells secretly. In contrast, the Puyuma only admit that the betel nut is used for benign praying, as well as for chewing, thus totally denying the evil intention that lies behind the use of the nut. It is more likely that Puyuma parents buried it secretly, with coaches giving silent consent. When their opponent found the betel nuts, they tended to blame the Beinan coaches.

Returning to the three theoretical approaches suggested earlier, the practice of Puyuma betel nuts matches the intellectualist approach, which emphasises that magic would eventually be replaced by science. Indeed, as the government gradually opened up educational opportunities to the masses, no betel nuts have been seen buried in the field since 1994. After all, performances of baseball players are based on scientific training, while witchcraft is viewed as superstitious, without any scientific support. If anyone wants to tamper with this principle through the use of magic power, they may well be ridiculed by others and exert a negative influence on the team. Although functionalists claimed that magic can engender the sense of confidence, competence, and control of players and coaches in achieving the desired results, and the structural-functionalists suggested that magic can help define Puyuma identity and consolidate tribal culture, it seems that coaches and players, be they Puyuma, Amis or Bunun, do not see the betel nut spell as providing such functions. However, the practice certainly reinforces the negative stereotypes held by other aboriginal tribes towards the Puyuma.

\section{ACKNOWLEDGEMENTS}

This study is supported by the grant from National Science Council (101-2410H-028-002). 


\section{NOTES}

1 To Amis society, salisin means the general worship of gods and ancestry, but the term transforms into black magic when referring to Puyuma's betel nuts.

2 Although Beinan Junior High School had a higher Puyuma percentage compared to Xinsheng Junior High School, the Amis still constituted the majority of the team.

3 The Hollywood style base, which is tough, durable and convenient to handle, has now been accepted for baseball grounds throughout the country, instead of primitive form bases fixed by nails.

4 The earliest possible reference to the Queen Mother of the West occurs in the Chinese Shang dynasty, after which she evolved from being immortal to being one of the major deities of Taoism.

5 Most Amis players and coaches mistakenly identified the deity that the Xinsheng parents brought as the demon-killing Third Prince of Jade Emperor, but it was actually the Queen Mother of the West.

6 The author recalls seeing the grudge between Beinan and Xinsheng's parents in certain newspapers, but unfortunately could not retrieve the article.

\section{MANUSCRIPT SOURCES}

Interviews and fieldnotes from Taidong County (2010) in the possession of the author.

\section{REFERENCES}

Baisu, Lixin 2010. Yuanzhumin zazhi: 'edaw zhuzhan. [News and Magazine of Aborigines: 'Edaw Bamboo Divination.] Taiwan Lihpao. Available at http://www.lihpao. com/?action-viewnews-itemid-5866, last accessed on April 18, 2013.

Bellwood, Peter 1991. The Austronesian Dispersal and the Origins of Languages. Scientific American, Vol. 265, No.1, pp. 88-93, doi:10.1038/scientificamerican0791-88.

Blust, Robert 1985. The Austronesian Homeland: A Linguistic Perspective. Asian Perspective, Vol. 26, No. 1, pp. 45-67.

Bradley, Mickey \& Gordon, Dan 2007. Haunted Baseball: Ghosts, Curses, Legends, and Eerie Events. Guilford, Conn.: Lyons Press.

Bradley, Mickey \& Gordon, Dan 2010. Field of Screams: Haunted Tales from the Baseball Diamond, the Locker Room, and Beyond. Guilford, Conn.: Lyons Press.

Burger, Jerry M. \& Lynn, Amy L. 2005. Superstitious Behavior Among American and Japanese Professional Baseball Players. Basic and Applied Social Psychology, Vol. 27, No. 1, pp. 71-76, http://dx.doi.org/10.1207/s15324834basp2701_7.

Cauquelin, Josiane 2004. The Aborigines of Taiwan. The Puyuma: From Headhunting to the Modern World. London \& New York: RoutledgeCurzon. 
Ciborowski, Tom 1997. "Superstition" in the Collegiate Baseball Player. The Sport Psychologist, Vol. 11, No. 3, pp. 305-317.

Frazer, James George 1948. The Golden Bough: A Study in Magic and Religion. Abridged edition. New York: Macmillan.

Gao, Zhengyuan 1995a. Yuanzhu min yu taiwan bangyun (1). [Aborigines and Taiwanese Baseball (1).] Shanhai wenhua shuang yuekan [Taiwan Indigenous Voice Bimonthly], Vol. 9, pp. 32-36.

Gao, Zhengyuan 1995b. Yuanzhu min yu taiwan bangyun (2) [Aborigines and Taiwanese Baseball (2).] Shanhai wenhua shuang yuekan [Taiwan Indigenous Voice Bimonthly], Vol. 10, pp. 26-30.

Gmelch, George 1971. Baseball Magic. Society, Vol. 8, No. 8, pp. 39-41, http://dx.doi. org/10.1007/BF02908325.

Gmelch, George 1992. Superstition and Ritual in American Baseball. Elysian Fields Quarterly, Vol. 11, No. 3, pp. 25-36.

Gmelch, George 2009. Baseball magic. Sociology 101. Available at http://sociology101. net/readings/Baseball-Magic.pdf, last accessed on April 18, 2013.

Historical Records 1963 = Historical Records Committee of Taidong County 1963. Taidong xianzhi. [General Records of Taidong County.] Taidong: Taidong County government.

Kasahara, Masaharu (translated by Shufen Huang) 2009. Taiwan beinan zhu de liangge jisi. [Two Ancient Ceremonies of Puyuma Tribe in Taiwan.] Dong taiwan yanjiu [Research on Eastern Taiwan], Vol. 13, pp. 95-138.

Lin, Boxiu \& Zhu, Zimin 2009. Huadong bangqiu yu yuanzhu min. [Baseball and Aborigines in Hualian and Taidong.] Yundong wenhua yanjiu [Studies in Sports Culture], Vol. 9, pp. 67-108.

Lin, Erlang 2005. Yi daba liujiu buluo de shijian jingyan chujian beinan zu wushu de lilun. [The Fundamental Theory Construction of Wizardry in Puyuma Tribe Based on the Actual Experience in Damalakaw.] Unpublished master's thesis. Tainan: National University of Tainan.

Lin, Huawei \& Lin, Meijun 2005. Diancang Taiwan bangqiu shi: Jianong bangqiu. [The Classical Collection of Taiwanese Baseball History: Jianong Baseball Team.] Taipei: Sports Affairs Council.

Malinowski, Bronislaw 1935. Coral Gardens and their Magic: A Study of the Methods of Tilling the Soil and of Agricultural Rites in the Trobriand Islands. 2 vols. London: George Allen and Unwin.

Ministry of Interior 2010. Available at http://sowf.moi.gov.tw/stat/month/m1-08.xls, last accessed on April 18, 2013.

Qiu, Weicheng 2003. Shi suolian haishi yuyi: Yuanzhu min bangqiu xuanshou de yundong zhilu. [Chains or Wings: The Sporting Path of Aboriginal Baseball Players.] Unpublished master's thesis. Hualian: National Hualien Teachers College.

Qiu, Yunzhu 2008. Shehui jiegou yinsu yu yuanzhu min yundong xuanze zhi tantao: Yi bangqiu yundong weili. [Social Structures and Choice of Aboriginal Movements: A Study Based on Baseball Sport.] Unpublished master's thesis. Xinzhu: Yuan Ze University.

Radcliffe-Brown, Alfred 1948. The Andaman Islanders. Glencoe, IL: Free Press. 
Song, Longsheng 1965. Nanwang cun beinan zu de huisuo zhidu. [The Puyuma Youth Training System in Nanwang Village.] Kaogu renlei xuekan [Journal of Archaeology and Anthropology], Vol. 25/26, pp. 112-144.

Song, Longsheng 1998. Taiwan yuanzhu min shi: Beinan zhu shipian. [The History of Taiwanese Aborigines: The History Article of Puyuma.] Nantou: Historical Research Commission of Taiwan Province.

Sun, Minying 2001. Ma Zhili. [Ma Zhili.] In: Wang, Hesheng (ed.) Taidong xianshi: Renwu pian. [The History of Taidong County: Articles on Figures.] Taidong: Cultural Center of Taidong County, pp. 210-211.

Temporary Committee $2000=$ Temporary Investigating Committee on the Old Customs of Taiwan 2000. Fanzhu guanxi diaozha baogao shu dier juan amei zu beinan zu. [The Investigation Report on Customs and Habits of Barbarian Ethnic.] Vol. 2, Amis and Puyuma. Taipei: Institute of Ethnology Academia Sinica.

Tian, Zheyi 2002. Taiwan de yuanzhu min: Beinan zu. [Taiwanese Aborigines: Puyuma.] Taipei: Taiyuan chuban she.

Tylor, Edward Burnett 1871. Primitive Culture: Researches into the Development of Mythology, Philosophy, Religion, Art, and Custom. London: J. Murray.

Wang, Huimin 1994. Hongye de gushi. [The Story of Red Leaf.] Taipei: Minsheng bao.

Wang, Songshan 2001. Taiwan yuanzhu min de shehui yu wenhua. [Aboriginal Society and Culture in Taiwan.] Taipei: Lianjing chuban she.

Wei, Huilin 1965. Taiwan tuzhu shehui de buluo zuzhi quanwei zhidu. [The Tribal Organisation and Authoritative System in Taiwan's Indigenous Society.] Kaogu renlei xuekan [Journal of Archaeology and Anthropology], Vol. 25/26, pp. 71-87.

Xie, Shiyuan \& Xie, Jiafen 2003. Taiwan bangqiu yibai nian. [One Hundred Years of Baseball in Taiwan.] Taipei: Guoshi chuban she.

Yang, Jiangying 2003. Mukiangai: Jianhe beinan wushi de yishi shijian. [Mikiangai: The Rites and Practices of Puyuma Wizards in Jianhe.] Unpublished master's thesis. Xinzhu: National Tsing Hua University.

Yu, Junwei \& Zeng, Wencheng 2004. Taiwan bangqiu wang. [Taiwan Baseball King.] Taipei: Woshi chuban she.

Yu, Junwei 2007a. Playing in Isolation: A History of Baseball in Taiwan. Lincoln \& London: University of Nebraska Press.

Yu, Junwei 2007b. The Hongye Legend in Taiwanese Baseball: Separating Myth from Reality. The International Journal of the History of Sport, Vol. 24, No. 10, pp. 1264-1280, http://dx.doi.org/10.1080/09523360701505379.

Yu, Junwei \& Bairner, Alan 2010. Schooling Taiwan's Aboriginal Baseball Players for the Nation. Sport, Education and Society, Vol. 15, No. 1, pp. 63-82, http://dx.doi. org/10.1080/13573320903461079.

Yu, Junwei \& Tang, Shengmei \& Zeng, Wencheng \& Jia, Yizhen \& Xie, Shiyuan \& Xie, Jiafen 2006. Xuandong suiyue: Taiwan bangqiu bainian shi. [History of Baseball in Taiwan 1906-2006.] Taipei: Chinese Taipei Baseball Association.

Zeitoun, Elizabeth \& Yu, Ching-hua 2005. The Formosan Language Archive: Linguistic Analysis and Language Processing. Computational Linguistics and Chinese Language Processing, Vol. 10, No. 2, pp. 167-200. Available at http://aclweb. org/anthology-new/O/O05/O05-3002.pdf. 
Zeng, Wencheng 2001. Qishi nianqian jianong bangqiu dui de guangmang. [The Sparkling Blade of Jianong Baseball Team Seventy Years Before.] Guomin tiyu jikan [National Sports Quarterly], Vol. 30, No. 4, pp. 50-64.

Zeng, Yujuan 2009. Shengming li yu lingli de meijie wu: yu KaTatipuL beinan ren binlang wenhua weili. [The Medium of Vitality and Mana: A Case Study of Betel Nuts Culture among the Puyuma in KaTaTipuL.] Taidong: National Taidong University.

Zhang, Jingguo (ed.) 1983. Zhonghua minguo shaobang qingshao bang qingnian bangqiu fazhan shishi. [Historical Facts about Little League Baseball, Junior High School Baseball, and Senior High School Baseball in the Republic of China.] Taipei: self-published.

Zhang, Tingrong 2007. Taidong geji xuexiao bangqiu yundong fazhan zhi yanjiu (19452005). [A Study of Baseball Development at Different Levels of Schools in Taidong (1945-2005).] Unpublished master's thesis. Taidong: National Taidong University. 


\title{
ESTONIAN FOLK DANCE: TERMS AND CONCEPTS IN THEORY AND PRACTICE ${ }^{1}$
}

\author{
Sille Kapper
}

\begin{abstract}
The article provides an overview of the changes that have occurred in the concept of 'folk dance' in Estonia from the end of the 19th century until today. The diachronic analysis of both theoretical and practical discourses is based on Estonian-language paper and web publications where the word rahvatants (folk dance) has been used as a term or where the concept is defined; an inquiry among the members of a folk dance group, and my personal ethnographic fieldwork in the folk dance world of Estonia. My borderline position between the roles of a dance researcher and a dancer and folk dance teacher in practice makes it possible to switch between different discourses and find their intersections. Shifts that occur in terms and concepts used in both scientific and public classifications, as well as in specialised discourses situated between them, reflect varied trends in the Estonian dance tradition during the 20th century and explain the development of the present situation.
\end{abstract}

Keywords: folk dance, traditional folk dance, folklore, stage folk dance, national dance, choreography, dance as art form, performing arts

\section{INTRODUCTION}

In the minds of contemporary Estonians, the meaning of 'Estonian folk dance' is diverse, ranging from more or less staged presentations of earlier village dances to any kind of dancing that ordinary people practise in Estonia today. In everyday speech and popular discourse folk dance is often defined through the national costume worn by the dancers, no matter what the choreographic text that they perform. Former Folk Dance Celebrations ${ }^{2}$ have been renamed as Dance Celebrations to contend against such a definition, but the participants are still called folk dancers. So do I, introducing myself usually as a folk dance teacher just because this is the shortest way to refer to my field of activity.

I graduated from the university as a choreographer, have been teaching traditional and stage folk dance for about 25 years, and doing conscious, prepared and organised ethnochoreological dance research for the last eight years. Those two different activities have placed me in a borderline position between theory 
and practice, and this is where I start my search for the answer why the essence of the term 'folk dance' is constantly fluctuating in our minds.

Estonians often hold lively discussions about the term 'folk dance'; some of us express very clear principles about what is or is not the (Estonian) folk dance, and sometimes we do not understand each other because of the different meanings assigned to the term. Estonians are not the only ones to have these terminological problems. Similar arguments arise internationally, among dance scholars as well as enthusiasts. However, these discussions show that the topic is important for the discussants. To improve understanding between different parties, I would first like to show how the present situation has emerged in Estonia and then look for intersections between the different meanings attributed to the term 'folk dance'. The article provides an overview of changes in the concept of 'Estonian folk dance' in local theoretical and practical discourses.

\section{EARLIER RESEARCH, PROBLEMS AND THEORETICAL BACKGROUND}

Dance Words, a collection by Valerie Preston-Dunlop (1998), well illustrates the fragmented situation that had developed in dance theory and practice by the end of the 20th century. It provides several definitions of ethnic, folk, national and traditional dance, given by dance scholars, dancers, choreographers and writers and based on different classificators. Unfortunately, without an insight into the historical formation of concepts, the total set of explanations remains rather more confusing.

The historical development of the concept 'Estonian folk dance' has not been scientifically addressed before. However, the vagueness of the term 'folk dance' has been observed by many researchers worldwide (e.g. Hoerburger 1965, 1968; Hoppu 2004; Nahachewsky 1995, 2008), including Estonians (Tampere 1962, 1975; Torop 1992, 1995; Vissel 2004; Krause 2007). The concepts of folk and traditional music in Estonia have been thoroughly addressed and their changeability has been considered by Estonian ethnomusicologists Ingrid Rüütel (1987, 2004) and Taive Särg (2002, 2004, 2005, 2010; Särg \& Johanson 2011). Based on the analogy with music but taking into account the later emergence of interest in dances, it is maintained that the concept of 'Estonian folk dance' first started to evolve at the turn of the 19th century under the influence of the ideology of national romanticism, which idealised the lore and identity of Estonians as the peasantry.

Rüütel (2004: 221-222) provides several definitions of folk music, one of them stating that it is "music practiced in a community, no matter if based 
on oral traditions, publications or the media, and whether it changes or not", which resembles the classification of the folk dance as "any kind of dancing of ordinary people". As we will see further on in this article, such a definition, although useful for ethnochoreological research in contemporary communities, is still rarely used in Estonia, probably because of the aforementioned strong connection of the concept of folk dance with nationality ideas.

In traditional folklore studies, folk music is considered not professional and not connected with official institutions. Based on this, Särg (2005) would exclude secular choir singing and church music from the term 'folk music'. The practice termed as 'folk dance', on the contrary, often also constitutes a hobby, which in contemporary Estonia is very much influenced by professional teachers and choreographers well organised by NGOs or local governments, and to some extent even financially supported by the state. Therefore, the theoretical basis of folklore studies is not sufficient for addressing the concept of 'folk dance' nowadays; it has moved into the fields of specialised and professional culture, dance as an art form and performing arts in general.

In the article about the opportunities of Estonian folk dance research today (Kapper 2009), I used the term 'folk dance' in its broadest sense, including the dancing performed by any 'folk' (Dundes 2002) with any purpose, in the past and present, and also author choreographies. When approaching dance folklorism in Estonia at the turn of the 20th century (Kapper 2006, 2008), I narrowed the concept 'folk dance' down to peasantry dance traditions practised in their primary or secondary contexts (Honko 1998), and excluded author choreographies in order to distinguish between variable traditional dancing and the fixed rules of stage dance style. The need for this kind of distinction soon led to a wider introduction of the term 'traditional dance' (Estonian: pärimustants) in theoretical as well as practical discourses, which is described further on in this article.

Internationally, several definitions of 'folk dance' have been offered. The classification has been based on dance environment (it is a village dance), performer (the dance of members of certain national groups, the dance of commoners, the dance of amateurs as opposed to professionals), textual content (derived from ritual, agricultural, martial activities), or the identity of the recipient of the communicated message (a 'communal' dance, for the dancers themselves) (Nahachewsky 1995: 13). In a performer-based specification, the changed definition of 'folk' comprising everyone from (illiterate European) peasants to any group of people who share a common factor (Dundes 2002: 11-32), does its job well in theoretical discourse, but in the field of Estonian 'folk dance' practice the term 'folk' (Estonian: rahvas) tends to be mixed up with the word 'nation' (partially due to its similar sound in Estonian: rahvus), and through this connection once again coincides with (the romantic imaginations of) the peasantry. 
Young Estonian cultural theoretician Leenu Nigu (2011) has defined the 'Estonian national dance', meaning stage folk dance choreographies, as a style with certain movement vocabulary, sets of clearly defined national costumes and music, disciplined training system and choreographed mass spectacles, the repertoire of which conveys a shared idea of nationality and the performing of which reinforces the nation as an "affective community" (Gandhi 2006: 1-10). However, the invented tradition (Hobsbawm 1983) of 'national dance', hereinafter termed as 'stage(d) folk dance' is a living practice in Estonia ${ }^{3}$ now and, as such, is also interpreted by Nigu (2011). In popular discourse such dancing is also termed as rahvatants (folk dance). Sometimes the attribute 'stage(d)' is added, but it is often omitted. I suggested the corresponding Estonian term rahvuslik tants (national dance) in 2009 and it is sometimes used in specialist conversations but has not been put into wider circulation. This shows how theoretical discourse may provide tools for distinguishing new phenomena by naming them differently. Based on popular understandings, everyday use remains conservative because the distinction is not important or functional as we will see below.

As terms and concepts are in the focus of this writing, it is necessary to stress that I use the word 'concept' for thinking and knowledge units (Tavast 2004; Erelt 2007: 44), while 'terms' stand for vocabulary units in specialised discourses. A concept reflects a phenomenon in reality by way of its essential traits, connections and relations. Looking at dances in choreological perspective (Preston-Dunlop 2006), the essential traits of 'folk dance' - the movements and their qualities - are included in the main word of the expression ('dance'). The attribute 'folk' is critical for the dance context- and function-centred anthropological approach (Giurchescu \& Torp 1991; Royce 2002). By integrating choreology and anthropology into a holistic perspective, the expression 'folk dance' is addressed as a whole.

Dance has been studied as a communication process, where messages are sent between co-dancers or from the performer to the audience. All dance components (the movements, music, costumes, etc.) may change according to the relations and physical or cultural distance between the sender and the receiver (Kaeppler 1989: 451; Nahachewsky 1995: 1-6; Kapper 2009: 79-80). The phenomena commonly called 'folk dance' often differ along the participatory-presentational axis. Different message receivers and contexts of the communication process cause changes in the movement vocabulary and performing styles. These changes are especially remarkable when traditional folk dance forms in their authentic settings are compared to staged compositions.

Traditional folk dance 'in the field' and staged folk dance presentations have been referred to as parallel traditions (Shay 2002: 17-18), but as we can see in 
practice, those parallels cross, influence each other, and are connected to each other. This is also suggested by the theories of the first and second existence of folk dance (Hoerburger 1968: 30; Honko 1998), the "third existence dance" (Nahachewsky 1995: 13), which stands for social dance traditions influenced by revival activities, and the classification of folk dance revival strategies (Nahachewsky 2008). Lauri Honko (1998) has described folklore as a process that includes traditional practices within and for a social group but also outside collecting, archival recording and research, up to 'second life' phenomena like revival, use in cultural politics and commodification. Such a viewpoint justifies the anthropological view and use of the term 'folk dance' to signify dancing as part of folklore, to stand for the tradition as a continuous process in general, no matter how essential changes in choreographic texts are brought in. Nevertheless, in choreology and specialised discourses there has still been a need to discern also at least the two basic sub-phenomena (traditional/participatory and stage/presentational), especially because of epic differences between their movement content and performing styles. In the following analysis I explore the development of the Estonian folk dance in two main directions, concurrent changes in concepts, and static stability in terms during the 20th century and up to nowadays.

\section{SOURCES AND METHODS}

The research material - texts containing the word rahvatants (folk dance) published in Estonia from the end of the 19th century until 2009 - were analysed in diachronic order, highlighting the passages where the term 'folk dance' was used or the concept was defined. The materials can be divided into two main groups: reference books and periodicals. Under reference books belong Estonian general encyclopedias (Väike 1937; ENE) and specialised literature on the Estonian folk dance, both of which should be based on scientific classifications. Periodicals along with the Internet rather reflect popular understandings.

For the latter, I also questioned some contemporary folk dancers, members of a hobby group, 7 men and 9 women aged 30 to 49 years. It was a typical Estonian folk dance group, whose activities include physical training, high relative importance of author choreographies in the repertoire, recorded music for accompaniment, uniform costumes, etc. (Kapper 2008). On May 12, 2009, at the beginning of their usual rehearsal, I asked them to write what folk dance means for them personally. The information about the research project was given but no other discussions preceded the writing. I did not know those dancers before and they did not know much about my professional activities 
or opinions. Their answers were analysed using the method of conventional qualitative content analysis (Laherand 2008: 290-294), in which categories are found directly from the data.

Additionally, an important part of my data derives from personal ethnographic fieldwork conducted since 2004 in the world of Estonian folk dance. Records in my fieldwork diary comprise observation and participant observation data from different kinds of folk dance events like festivals, workshops, jams and parties, folk dancers' rehearsals, performed programmes, memos from organising meetings of the CIOFF Folklore Festival Baltica and Estonian Song and Dance Celebrations, quotations from conversations and ethnographic interviews with young and old dancers, members of local communities, folk dance groups and ensembles as well as unorganised enthusiasts, choreography students, dance teachers, producers, cultural managers, etc. My continuous fieldwork also encompasses the observation of Estonian folk dance-related discussions in the media, including social media (Facebook). Qualitative content analysis of the fieldwork diary texts in comparison and combination with the aforementioned materials forms the basis for my conclusions.

\section{FIRST INTEREST: FOLK DANCE AS ESTONIANS' OLD AND VALUABLE HERITAGE}

As Laugaste (1963: 101-110) has argued, the first lines about dance in Estonian folkloristics were written by Baltic German estophiles Fabricius (1610), Hupel (1767), Schlegel (1788, 1819), and others. Schlegel's vocabulary includes, for example, 'Tanz der Estnischen Nation', 'Tänze der Nation' and 'Nationaltanz', which means that the dances of another ethnic group, the cultural Other, are observed from the outside.

In 1892, journalist Georg Eduard Luiga wrote in the newspaper Olevik (The Present) ${ }^{4}$ :

Estonians also have their own old folk dances, [...] but are they still alive anywhere? [...] Folk dances convey the mode and habit of the folk and often express it more clearly than some other memories from old times. [...] Most of them are certainly gone, dancers are dead, but there are still old men who can do one or the other dance. (Luiga 1892: 636)

The 'folk' in the quotation still means the ethnic group, and two important opinions may be noticed:

- Folk dances include something characteristic of the 'folk', which is valuable; 
- Folk dances are old and disappearing and, therefore, they must be maintained artificially, e.g., by learning and notating from old people.

Luiga suggests that young men should learn dances from the old ones until "a smart guy invents a dance script so that folk dances can be preserved for researchers" (Luiga 1892: 636). Actually, dance notation systems existed in those times, but knowledge about them had probably not reached Estonia yet, or they were considered unsuitable for folk dance notation. ${ }^{5}$ So the lines in the newspaper started to embed in the popular mind the principles of classical folklore studies, which claimed that folklore, including folk dances, was old and existed in the memories of elderly people only, and that contemporary dance traditions and repertoire were of no interest.

As late as in 1913, Anna Raudkats, the first specially educated Estonian choreologist, who had learned folk dance notation at the Helsinki Gymnastics Institute, made her expeditions to Kolga rand (coast of Juminda Peninsula) on the northern coast, and Setumaa in the southwest of Estonia, which resulted in descriptions or mentioning of total 38 dances (EÜS X 1147/1335). Raudkats herself considered many of them as "modern salon dances with local names" (Tõnnus 1991: 21, 83) and did not appreciate them much; she was interested in notating older dance forms ${ }^{6}$, which would differ from contemporary fashionable dances and therefore fit into the repertoire of folk dance groups (Pomozi 2008: 129-130; Tõnnus 1991: 73-93). Thereby, the notion of 'true' and 'genuine' Estonian folk dance, supposedly reflecting earlier innocent and natural rural lifestyle, was established. Although Raudkats valued older dance forms more, she also notated the dances that were fashionable and circulated in Estonian villages at the beginning of the 20th century, nowadays sometimes referred to as old ballroom dances ${ }^{7}$.

Vanad seltskonnatantsud (Old Ballroom Dances) was the title of a book (VS 1997) containing notations of popular dances from the 1st half of the 20th century, first published as late as in 1997, which brought along an active use of those dances in the repertoire of Estonian folk dance groups. The dances that were not considered 'folk' by Raudkats and her contemporaries were then old enough to acquire this status. The term 'old ballroom dances' yet refers to the distinction made between them and earlier repertoire layers in specialised as well as popular discourses. Differentiation based on the short age and little variability of some old ballroom dances may be justified but functionally they do not differ from earlier types - social interaction and amusement were the main functions of peasantry dancing at least since contra dances (Põldmäe \& Tampere 1938: 33, 39; Torop 1995: 9) or earlier forms of couple dancing (Torop 1995: 22-23) appeared. Kristjan Torop (1995: 17) directly referred to the Es- 
tonian folk dance as "peasants' ballroom dance". The principle of amusement dancing among peasants reaches back to the Late Middle Ages also in Estonia (Russow 1993: 86).

In spite of this, in the sources published until the second decade of the 20th century, the Estonian folk dance is addressed as a part of folklore, a valuable witness of national history, which is unfortunately disappearing and must be saved by fixing in notations. Writers and notators, whether Estonians or not, exclude themselves from the 'folk', in whose dances they are interested.

\section{TWO DIRECTIONS}

Due to confusing times - World War I, the Estonian War of Independence, and the establishment of the Republic of Estonia - the dances collected by Anna Raudkats in 1913 were published only as late as in 1926. The publication of Raudkats's Eesti rahvatantsud (Estonian folk dances) reinforced the idea that 'folk dances' were supposed to be old-fashioned dances. The ones in actual circulation among ordinary Estonians in the period that the book was published did not qualify as 'folk dances' (Raudkats 1926: 8, 11). Such a choice was made due to romantic idealisation of rural peasant life and the wish to use dancing to support national identity feelings in the urbanising society. For that purpose, the collected dances were directly brought to stage to demonstrate their manifold values: Raudkats (ibid.: 9) was convinced that "national character is manifested in folk dances in its purest and most original format". As an educated gymnastics teacher she also emphasised health benefits gained from folk dance training, especially when certain instructions were followed, and she also believed that "folk dancing develops feelings of communion and arouses love and respect towards ancestors' traditions and arts" (ibid.: 10-14). The 'folk dancing' she advocates takes place mainly in school, group, and stage settings, which brings along a shift in the concept: from now on, 'folk dance' is the repertoire taught by teachers in groups and schools and performed on stages. Instead of rituals or amusement, the aim of folk dancing is physical exercise, aesthetic experience gained from displayed spectacles, and patriotic education.

Raudkats did not provide any literal definition of the Estonian folk dance; her position can be derived from her own writings and biography (Raudkats 1926; Tõnnus 1991). In the Estonian language, 'folk dance' (rahvatants) was first defined in Väike entsüklopeedia (Small Encyclopedia) as follows: "dances developed in peasant culture and characteristic of its spirit; main features usually internationally spread" (Väike 1937: 1247). Mentioning of the international character of the main features of folk dance is important in the scientific 
classification-based encyclopedia article, because it is different from the strong emphasis on national originality in practice. Later, in the Soviet period, the internationality of 'folk dances' was fully forgotten, and has slowly been re-found now, after Estonia regained independence. The encyclopedia article continues with folk dance typology by form and age, and three generally known folk dances are mentioned: labajalavalss, kaerajaan and tuljak. The written appearance of the latter gives an important hint - tuljak with the first character lowercase and without quotation marks certainly means the traditional dance, i.e., a folklore text and not the famous choreographed piece by A. Raudkats, which together with the above allows to conclude that this definition classifies the folk dance as part of folklore, omitting the revival movement or choreographers' art. The definition does not exactly say if 'folk dance' has to be old-fashioned, and therefore I looked up another article, 'ballroom dance' (seltskonnatants), in the same publication, which enumerates minuet, waltz, polka, tango, and foxtrot (Väike 1937: 1354), so the distinction between folk and ballroom dances remains somewhat unclear. I also looked for the term 'traditional dance' (pärimustants). There was no such entry in the book but the key word pärimus was there, with laconic reference to the term 'tradition' (ibid.: 1228).

The principle to classify old dance forms as 'folk dance' and leave living traditions aside was continued by Rudolf Põldmäe and Herbert Tampere (1938: 1-57), whose Valimik eesti rahvatantse (Selection of Estonian Folk Dances) in their interpretation "should provide an almost complete overview of our entire folk dance repertoire" (Põldmäe \& Tampere 1938: III). They also write:

The whole folk have participated in the creation of the folk dance and its taste is hidden in it. [...] Folk dancing should deepen our love for our ancestors and their creation, increasing the national identity of the youth. (Põldmäe \& Tampere 1938: 50)

Põldmäe and Tampere, however, suggest that "local revival activists should not forget folk dances of their surroundings" (Põldmäe \& Tampere 1938: 57 ) but, based on their background of classical folklore studies, they probably meant dances in the memories of elderly people rather than contemporary amusement of the youth. Similarly to Raudkats, Põldmäe and Tampere also refer to the healthiness of folk dance as physical exercise. The attitude that special training is required in order to perform folk dances (on stage) probably originates from this. The performing style exercised in groups and classes and shown on stage gradually changes according to the changed senders and recipients of the message.

Exceptionally, the folk music enthusiast August Pulst invited authentic performers to present their own dances at concert tours organised by him in 
1922-1936 (Vissel 2004: 113). While Raudkats sometimes stylised dances and always based them on at least minimal rules of performing arts, Pulst brought to the audience dances by traditional performers, without any arrangements or excess attention to the stage situation (ibid.: 112). Pulst was not an academically educated folklorist or dance teacher, and his common sense did not consider folk dances 'dead', as they were classified by the revival movement. The repertoire presented by Pulst resembled Raudkats's collection, and some of his dancers had also served as informants for the latter on her notation trips.

Hence, folk dance revival movement simultaneously started into different directions - folk dances were performed on stage in more or less stylised forms, and also new choreographies were created (Vissel 2004: 111-112), which in the beginning consisted mainly of new combinations of basic movements and fixed-format constructions according to certain pieces of music (e.g. Raudkats 1926: 51-66). Contemporary specialised literature (Raudkats 1926; Põldmäe \& Tampere 1938) and periodicals (A. R. 1926; R. S. 1932; Rändur 1933; T. L. 1935) diligently distinguish between 'original' folklore and folklorism. In case of adaptations or arrangements, books usually provide data of the choreographer. In the introduction of her book, Raudkats (1926: 7) declares which dances she has composed using different regional notations, and suggests that the reader should look at the original ones at the Estonian National Museum. Põldmäe and Tampere emphasise that dances are published in the original notation, just as they have been collected "from the folk" (Põldmäe \& Tampere 1938: III).

In periodicals the traditional folk dance is seen as part of ancient farm life, whereas stylisations and new creations fit into the modern educated (urban) life. The ancient is generally respected and highly valued, while the upstart disparaging attitude is condemnable (e.g. Rändur 1933), but the need to develop the nation's 'own culture' (Estonian: omakultuur) further, in accordance with modern requirements, is articulated. Stylising took place with folk art in general, e.g., in the elaboration of national costumes, and it also comprised the revival of past dances and creation of new folk-dance-based choreographies. As a further development, besides national ideals expressed in arrangements and choreographies, Raudkats (1926: 13-14) sees the clarity and accuracy of dance movements. Põldmäe and Tampere (1938: 49-57) are profound in their approach to folk traditions and at the same time tolerant to any directions of development. Thus during the first period of independence in Estonia the concept of 'folk dance' obtains a new dimension - in addition to its position as part of folklore, it is addressed as an art form (performing arts). This distinction is quite clearly made in scientific and specialised as well as popular discourses. 


\section{NATIONAL IN FORM, SOCIALIST IN CONTENT}

Further development of the Estonian folk dance was dashingly continued after World War II, when in the whole Eastern Europe folklorism was taken into use in cultural politics as an instrument for education and social change (Giurchescu 2001: 117). The transformation from social to artistic significance, and from variation to fixed forms (ibid.), was exactly what happened to 'folk dance'. These processes started earlier in parallel with normal developments in the field and were not only the consequence of the Soviet occupation; so in the following 50 years (1940-1990) the situation got out of balance. While folklore, including folk dance, was a process that was generally uncontrollable by any government or institution, it was logical to replace it by a strict selection, rules and norms of folklorism - without changing the term. From now on the Estonian folk dance, national in form, socialist in content, consisted in carefully selected stylised movements and presented on stage the hard-working, well trained, healthy and happy Estonians as part of the Soviet people. The promotion of folk dance and music was used to legitimise the Soviet system for foreigners and emphasise the seemingly democratic national policy and "flourishing of nations" (Mertelsmann 2003). The promotion of folk dance here unequivocally means the preference of the staged dance.

Specialised literature (Toomi 1947, 1953) still contains references to archival recordings, but published dance descriptions are rather different from the notations - choreographic texts have been improved and developed considerably, from standardised performing manners up to new parts added to the dances. The same books contain compositions based on original authorship, and partially due to this, folk dance is subordinated to the same requirements as author choreographies (Torop 2008: 12). In addition to the aforementioned standardisation, the mode how movements are executed is prescribed in a most strict and accurate way.

Standardisation and homogenisation are very useful in mass spectacles (Dance Celebrations), in which thousands of dancers simultaneously perform at a stadium and the artistic expression is created by their placement and synchronised movements. The great popularity and massive character of this phenomenon would even justify its name as 'folk dance', but choreography of those events is of a different style, which is characterised by expanded and synchronised movements, dancers trained according to specific character dancelike system based, in principle, on classical ballet, homogenised costumes, accompaniment of symphonic music, etc. The connection of the new stage style to folk traditions is loose, although single stylised elements of traditional folk dances may be used. 
Traditional folk dance forms have been hidden behind the new style for decades; folk dance groups do not perform them. In communities the existence of living traditions naturally continues and dance folklore is collected, from now on in addition to notations, also with the help of a film camera. In 1956 Milvi Sikk and Ingrid Rüütel notated tens of dances on Kihnu Island, in the 1960s the first eight hours of film material was shot in Pärnu County, on the islands of Saaremaa and Muhu, on Kihnu Island again, etc. (Vissel 1999: 57; ERA FAV 26 and DV 109-119), and in the 1970s Kristjan Torop started collecting dances in many places of Estonia (Vissel 1999: 58). The ongoing aim of folklorists was to store old and old-fashioned material, but now also many old ballroom dances were found sufficiently 'folk' and notated. Fashionable dances like tango, foxtrot, popular Latin dances or short-time favourites of the second half of the 20th century like lipsi or twist were not captured.

In the first decades of the Soviet period, the term 'folk dance' stood for the staged style only. This was proudly presented by the ruling ideology as national heritage - in fact, staged (ballet-based) character dance with new individual choreographies was presented. Folklore movement, which slowly developed in the 1970s and explosively spread at the end of the 1980s (Vissel 2004: 121), tried to turn back to traditional folk dance forms; often, however, with performing styles influenced by intermediary stage folk dance training. A glance into the Estonian Soviet Encyclopedia (ENE) confirms that two different concepts are signified with the term 'folk dance' - in the first edition it is defined as "traditional dance creation of the folk" (ENE 1970: 162; 1974: 384-385). The article describes the traditional folk dance and mentions stylisation as an opportunity. The final sentence of the article sounds period-specifically, reading: "In Soviet Estonia, special attention has been paid to folk dance", which clearly refers to stage style, based on what is indicated above. The second edition of ENE (1987: 448) contains a somewhat longer article titled Estonian Folk Dance, which also consists of an integrated overview of primary traditions, collection and publication of dances, and folk dance as a hobby and performing art. At the end of the article it says: "In the 1960s interest in folk dance heritage livened up. [...] There are genuine Estonian folk dances in the programmes of most folk dance groups" (ENE 1987: 448). Neither the extent of folk dance heritage nor the difference of genuine Estonian folk dances from the rest (non-genuine?) are explained in the encyclopedia.

Based on specialised literature and the realities of folklore studies indicated in this chapter, one can conclude that in scientific and specialised discourses two parallel concepts have been developed: firstly, the Estonian folk dance valued as national heritage, consisting of dances that have proved their 'traditional' and 'folk' character by a sufficiently long-term survival, and, secondly, the Estonian 
folk dance as a performing art and folklorism, which can be subordinated to artistic but also political choices and direction.

From the choreological point of view, dance movements show that during the Soviet period stage folk dance style obtained and reinforced its most characteristic traits so that instead of folklore studies the discourse to address it should have been dance studies - ethnochoreology and dance anthropology.

In public discourse, the Soviet regime used a common term 'folk dance' to keep folk dance as folklore and folk dance as performing art confused because this was beneficial - this way national values attributed to traditional folk dances during the national romanticism period and first period of independence in Estonia could be used in favour of legitimising the Soviet rule, although the dance content and performing style and manners had changed.

\section{RE-INDEPENDENT POSTMODERN ESTONIA}

The 1996 Explanatory Dictionary of Standard Estonian (EKSS) also defines folk dance as "traditional dance creation of the folk", just like ENE did in 1970; among examples, expressions such as "original folk dance" and "stylised folk dance" are provided (EKSS 1996: 804), whereby it is shown that folk dance may be 'original' - meaning traditional - or stylised and could be termed accordingly. The entry published in 1996 could have been written in the Soviet period and therefore reflects the ambiguous concept of 'folk dance' of that time. The second edition of the EKSS, published in 2009, changed neither the entry nor the explanation.

The EKSS was compiled by lexicographers from the Institute of the Estonian Language, and it is a profound description of the contemporary Estonian language, which should provide support in the understanding and research of the meaning of Estonian words (Keelevara 2009). The explanation of the word 'folk dance' (Estonian compound: rahvatants) itself clearly shows that the general concept of 'folk dance' is far from the "traditional dance creation of the folk" only: it also includes individual creation and choreographic activities, in which traditionality is not the determining aspect like in folk dance teaching in schools or groups, and folk dance as physical exercise. At the same time there is quite clear opposition between the two parts of the concept, which makes it more reasonable to define two different concepts instead of the confused and diffusive one.

In scientific and specialised discourses the need to find more suitable and exact terms for the different concepts of folk dance has resulted in several variants (Torop 2008: 11; Vissel 2004; Arraste 2008: 5) that are not presented here 
to save space, but that all in general still translate into English as 'traditional (authentic, original, genuine) folk dance' as opposed to 'stage folk dance'. The principal distinction is made on the participatory-presentational axis. In general and public discourses, both of those opposite poles are also referred to merely as 'folk dance', leaving out any specifying attributes.

Due to its presentational character, and the historical and political background addressed before in this article, stage dance has remained more visible in society, which has led to the inclination of the concept of 'Estonian folk dance' towards stage style. In re-independent Estonia, stage folk dance obtained the main and principal position within the notion 'folk dance'. So to say, the term 'folk dance' was occupied by the stage style concept and reality.

For the notion 'traditional folk dance', therefore, a new term was necessary to distinguish between two possible styles. A new word pärimustants ${ }^{8}$ was coined for this purpose, partially inspired by the term pärimusmuusika (traditional music), which since the 1990s had been used to distinguish old rural music styles and their contemporary adaptations from adaptations of musical folklore made according to Soviet ideology, popularly termed as rahvamuusika (folk music) (Särg \& Johanson 2011: 137).

Four editions of the Dictionary of Estonian Folk Dance Terminology (Torop 2008) do not include the word pärimustants (traditional folk dance) as a defined term or key word, ${ }^{9}$ nor do contemporary dictionaries of the Estonian language $(\text { EKSS 1996, 2009 })^{10}$. In academic writing, the term pärimustants was first used by Estonian ethnomusicologist and dance researcher Anu Vissel (2004: 125) to mark the dancing that preceded stage folk dance style and from which the latter was evolved. Ingrid Rüütel (2009: 53, 74) signified by the term pärimustants traditional folk dance texts that might circulate "in their traditional and modern context". At the same time, the use of the term pärimustants among some traditional music and dance lovers could also be noticed (Kapper 2009: 79). Google search on November 25, 2009, showed that the word pärimustants most often appeared in connection with the Estonian Traditional Music Center ${ }^{11}$ (ETMC), being mainly contained in introductions of short training programmes, curricula of music and hobby schools, and an innovative dance production by traditional dance enthusiasts. A new search three years later, on September 20, 2012, showed a remarkable growth in numbers but the context had remained similar: hobby education, training courses and workshops. In addition to the ETMC, the word was now used in web publications of many other organisations and institutions active in the field of research as well as training and cultural management. ${ }^{12}$ This shows how the latter as mediators between theoretical and practical discourses have started to actively spread the new term and concept coined in scientific research on the one hand, and inspired by popular understanding of traditional music on the other. 
By now, in popular understanding, the concept of pärimustants is still a little narrower than the concept of pärimusmuusika, which, according to Särg and Johanson (2011: 137), includes contemporary adaptations - traditional folk dance enthusiasts are rather cautious in respect of any artificial arrangements. Traditional folk dance lovers first emphasised its variability and improvisational character as a basic difference from stage folk dance (e.g., charismatic artists Jaak Johanson and Silver Sepp in Haav 2009; Meiessaar 2009; Kapper 2010). Dismissive feelings in respect of arrangements were caused by the knowledge about Soviet stage style adaptations, in which individual and local, regional and other communal peculiarities arising from improvisation were suppressed and replaced with standardisation. On the other hand, emphasis was put on the changeability of pärimustants in contrast to folklorism fostered within folklore movement, which was considered to over-idealise, imitate and cultivate fixed dance forms instead of accepting the changeability of living traditions.

However, all concepts are within their continuous dynamics, and by 2012 , based on discussions and practical experience, I was able to confirm that radical distancing of the concept 'traditional folk dance' from 'folk dance' in general was turning into a rather constructive search for alternative methods in adapting folk dance material collected by folklorists to contemporary aesthetics and lifestyles, without decreasing the high value attached to the dancer's individuality.

It is remarkable and, in light of the above, not surprising that there were no such categories as 'variability', 'improvisational', 'individual' or 'personal' in the answers given in 2009 by the members of the folk dance group questioned about their own understanding of 'folk dance'. Rather opposite categories as 'stable in time', 'old', and 'lasting from generation to generation' were highlighted in qualitative content analysis. These categories refer to the existence of the concept of 'traditional folk dance' also in the respondents' minds, as different features of the phenomenon are seen.

Another important category mentioned in the texts by the folk dance group members was 'nationality', which is less visible in connection with the concept and realities of 'traditional folk dance'. Based on traditional dance enthusiasts' statements in personal conversations and social media, I would say that tolerance and knowledge of internationally common features is greater among them. Local and regional peculiarities are of special interest in folklore movement (e.g., CIOFF Definitions 2012), but the all-Estonian national level is hidden behind them or left aside - maybe this can be seen as an expression of protest against stage-style standardisation. Performing groups typically reinforce their national expression with national costumes (which were also mentioned by dancers as a characteristic of folk dance), while traditional folk dance enthusiasts usually wear ordinary everyday clothing at their participatory events. 
Folk dance group members repeatedly defined folk dance by its functions, among which '(social) communication', 'amusement', 'education', 'physical exercise' and 'artistic expression' were named. I did not ask, but a dancer explained that "author choreographies are also folk dances". For that person, physical exercise and artistic expression were important qualities of folk dance, which refers to the concept of 'stage folk dance' rather than 'folk dance' in general. For several dancers, the complex how 'folk dance' functioned for them included traits from both concepts - traditional and stage. This refers to intermingling of presentational and participatory dance in folk dance group settings, which has also been noticed before: Torop (2008: 15) mentions in the definition of 'folk dance group' that folk dances are learned there just for fun or for presentation. I would use 'and' instead of 'or' because they both occur at the same time but are of different importance, depending on the inner culture of the group, value judgements, activity period or concrete situation (Kapper 2006; Nahachewsky 2008). The presence of both participatory and presentational categories was confirmed by the folk dance functions listed by dancers, and likewise the fact that the concept of 'stage folk dance' fits well into their broader concept of 'folk dance'.

All the answers of the folk dance group members were unique, and as unique are traditional folk dance enthusiasts' statements in the media and conversations. Concepts expressed in words are not always in full accordance with reality but reflect dreams and wishes about how things should be. Real dancing is almost as diverse as the above opinions. Postmodern fragmentation has reached the world of 'Estonian folk dance'. Nowadays everybody can find a community with certain values to adjust to or create a community according to his or her own beliefs and convictions.

\section{DISCUSSION}

After this diachronic analysis of changes, which have taken place in the terms and concepts reflecting the realities of 'Estonian folk dance', we can proceed to the intersections found between different classifications and discourses. To understand the mutual influences of theories and practices, some additional historical information about different revival activities is also provided in this section.

Starting from the first records, folklorists have defined Estonian folk dances as belonging to the past of a group positioned outside the collectors and researchers. The attitude to folk dance as an old-fashioned phenomenon vanishing with elder generations, and deriving from classical folklore studies, spread 
via publications and the media throughout nearly the entire 20 th century. The classification of folk dance as something different and 'other' makes it possible to relocate it from participatory to presentational settings: from everyday life of the peasantry onto the stage in front of a passive audience, and that is what happens in practice.

Since 1920, the Estonian folk dance in its presentational forms has been used in cultural politics - until 1940 for the purposes of patriotic and national education, in 1940-1990 to legitimise and propagate the socialist order, and since the 1990s (actually already from the second half of the 1980s, the Singing Revolution era) to reinforce the newly found national identity within the regained independence of Estonia. During the first period of independence in Estonia as well as in the Soviet period, stage folk dance was of little interest for folklorists and in scientific discourse in general. ${ }^{13}$ Therefore its differences from traditional dancing were neither analysed nor explained in public. Such silence in academic discourse and good visibility of the dance in presentational settings have resulted in widespread public understanding that nowadays stage folk dance is the only and regular further development of the folk dance, which corresponds to the requirements of contemporary society.

Based on researchers and students' interest in folklore from the past, including past dance forms, at the end of the 1960s, some pioneers of authentic folklore movement started their practice that explosively grew at the turn of the 1980s, but the leading position of stage folk dance was never completely balanced out. Dance folklorism exercised by folklore groups still mainly consisted in presentational dancing of 'original' forms learned from archival collections and performed with minor arrangements or almost without them. The term used for this kind of dancing was sometimes 'folk dance', but due to the strong connection of that term to stage folk dance, other opportunities were searched for. ${ }^{14}$ In scientific discourse, this revival phenomenon is classified as the second life of folklore, dances performed in presentational settings are also recorded for folklore archives, and changes in them are analysed as folklore texts. For public understanding there is no big difference from stage folk dance, although scientific research may point out many typical alternations.

The other revival movement, dance $\operatorname{clubs}^{15}$, started at the beginning of the 1990s as a general protest against any kind of presentational dancing, is the expression of a slightly different concept of 'folk dance'. For a period, in the rhetorics of dance club activists, stage folk dance and dance folklorism were considered principally the same (and condemnable), and high value was attached to participatory dancing. The dance club movement was first initiated and has until now been mainly led by musicians. It is different from other revival phenomena, and similar to authentic participatory situations that usu- 
ally depend on musicians. During the twenty years of dance club history, its participatory settings and live contact between dancers and musicians have really led to a living tradition that is carried on by a number of core enthusiasts, varies according to several factors like dancing locations, regions, music, dancers' personalities, emotional situation, etc., and still maintains some of its characteristic features through times.

Besides dance clubs, folklore groups' activities and festivals there are other settings for traditional folk dance in contemporary Estonia - training courses, workshops, traditional music concerts, parties, jams, etc., which mostly promote participatory dancing providing conditions for practising. The activity is then termed as pärimustants (traditional folk dance), just tants (dance), or sometimes signified with a wordplay rahva tants (literally: dance of the folk, meaning - dance of ordinary people).

Since 2009, there have also been single cases of bringing traditional folk dance into presentational settings on a level qualitatively different from stage folk dance. Those attempts are also initiated by (dancing) musicians and generally follow the route of contemporary traditional music in search of its 'internal authenticity' (Särg \& Johanson 2011: 138). Along with stage folk dance, those new directions of traditional folk dance are also appreciated, observed and analysed by dance researchers of today. In public understanding, at the moment, 'folk dance' (rahvatants) is mainly presentational and equals to 'stage folk dance', also referred to as 'national (stage) dance' (rahvuslik (lava)tants) while the concept of 'traditional folk dance' (pärimustants) ranges from old peasantry dance forms to their different uses in today's practice.

\section{IN CONCLUSION}

Within the general concept of 'folk dance', however, in addition to the abovediscussed common elements present in scientific as well as public classification, some discrepancies have attracted my attention.

In scientific as well as popular classification, quite a clear distinction is made between author choreography and so-called folk creation, in which the author is unknown or not important. Although both of them are termed 'folk dance', the specifying attributes available in public discourse are not always considered necessary. But author choreography and folk creation, so clearly distinguishable from each other in both classifications, turn out undifferentiated in presentational situations, when they are performed by dancers in national costumes. Then both stand for national expression in a visible and bodily format, and the origin of movement motifs or performing style does not matter. 
Choreographic text, of course, gives the sense of origin - the much more sophisticated movement vocabulary and complicated composition of choreographed pieces with usually quite standardised and homogenised performing style and other typically presentational details let us easily understand that there is no traditional folk dance in question. But such a movement-based perspective is interesting for researchers and folk dance specialists or enthusiasts; in wider public understanding the movement content of a dance is not the basis for classifying a phenomenon as 'folk dance', and even less as 'stage folk dance' or 'traditional folk dance'.

\section{NOTES}

1 The research was supported by ETF grants 7231 and 9132, the target-financed research topic SF 0130033s07 and the Centre of Excellence in Cultural Theory (project TK18U01).

${ }^{2}$ For the history of the Estonian Song and Dance Celebration traditions as a UNESCO masterpiece of the Oral and Intangible Heritage of Humanity see http://laulupidu.ee/ english/history/, last accessed on August 2, 2013.

3 As well as in most European countries.

4 Translation from Estonian here and hereinafter by Sille Kapper.

5 E.g. Beauchamps-Feuillet system widely used in the 18th century Europe for baroque dance notation, or the Stepanov notation for ballet in Russia.

${ }^{6}$ Mainly circle, chain, and contra dance types named Voortants, Saba tants, Rädi tants, Ingliska, Kadrel, Kargus, etc., and some earlier forms of couple dances (EÜS X $1213 / 1249<$ Raudkats (1913)).

7 Waltz, polka, schottische, and local forms of internationally spread one-melody couple dances, e.g., Krakuiak, Karobotska, etc. (EÜS X 1319/1421 < Raudkats (1913)).

8 The direct translation would be 'traditional dance', but to keep the connection with the general term for both parts of the concept of 'folk dance', the expression 'traditional folk dance' is used in this article.

9 Although its synonym rahvapärimuslik tants is used in movement descriptions (Torop 2008a: 31).

${ }^{10}$ However, pärimusmuusika (traditional folk music) is included in EKSS 2009 with a laconic explanation as rahvamuusika (folk music), as well as pärimus (oral lore, oral tradition) and pärimuslik (traditional).

${ }^{11}$ An NGO that organises traditional music festivals, concerts, trainings, etc. (Statutes 2012). 
12 Training Center of Estonian National Folklore Council, the Folk Culture Centre, the Estonian Folk Dance and Folk Music Association, Tallinn University, the University of Tartu, the Estonian Literary Museum, etc.

13 This happened not only in Estonia and the USSR. Anthony Shay (2002), when starting his research on state folk dance companies, claimed the same about the whole world.

${ }^{14}$ E.g. folkloorne tants that does not translate very well into English but means something like 'dance as part of folklore', and since approximately the second half of the first decade of the 21 st century, also pärimustants (traditional folk dance).

${ }^{15}$ Dance club (Estonian: tantsuklubi) is an informal social movement for practicing traditional folk dances mainly derived from Estonian villages from the end of the 19th and beginning of the 20th centuries. The movement started following the example of Hungarian táncház. Regular events are held in Tallinn and Tartu every two weeks, occasionally also in other places.

\section{ARCHIVAL SOURCES}

ERA - Estonian Folklore Archives

EÜS - Folklore collection of the Estonian Students Society in the Estonian Folklore Archives

FAV - Analogue videos in the Estonian Folklore Archives

DV - Digital videos in the Estonian Folklore Archives

\section{MANUSCRIPT SOURCES}

Sille Kapper's fieldwork materials in the possession of the author.

\section{REFERENCES}

A. R. 1926. Eesti rahvatantsud. [Estonian Folk Dances.] Postimees (newspaper), August 21, p. 3.

Arraste, Angela 2008. Saateks. [Foreword.] In: K. Torop: Eesti rahvatantsu oskussõnastik. Tallinn: Rahvakultuuri Arendus- ja Koolituskeskus, p. 5.

CIOFF Definitions $2012=$ CIOFF Definitions of Traditional Programs on the Stage 2012. Tallinn: ERFN. Available at http://www.folkloorinoukogu.ee/CIOFF_Definitions_ of_Traditional_353.htm, last accessed on August 2, 2013.

Dundes, Alan 2002. Kes on rahvas? [Who Are the Folk?] Tallinn: Varrak.

ENE 1970 = Eesti Nõukogude Entsüklopeedia 2. [Estonian Soviet Encyclopedia.] Tallinn: Valgus.

ENE 1974 = Eesti Nõukogude Entsüklopeedia 6. [Estonian Soviet Encyclopedia.] Tallinn: Valgus. 
ENE 1987 = Eesti Nõukogude Entsüklopeedia 2. [Estonian Soviet Encyclopedia.] Tallinn: Valgus.

EKSS 1996 = Eesti kirjakeele seletussõnaraamat. IV köide, 4. vihik. [Explanatory Dictionary of Standard Estonian.] R. Karelson \& V. Kullus (chief eds.). Tallinn: Eesti Teaduste Akadeemia Eesti Keele Instituut.

EKSS 2009 = Eesti keele seletav sõnaraamat. [Explanatory Dictionary of Standard Estonian.] R. Karelson \& V. Kullus et al. (eds.). Tallinn: Eesti Keele Sihtasutus. Available at http://www.eki.ee/dict/ekss/ekss.html, last accessed on August 2, 2013.

Erelt, Tiiu 2007. Terminiõpetus. [Textbook of Terminology.] Tartu: Tartu Ülikooli Kirjastus.

Gandhi, Leela 2006. Affective Communities: Anticolonial Thought, Fin-de-Siécle Radicalism, and the Politics of Friendship. Duke University Press.

Giurchescu, Anca 2001. The Power of Dance and Its Social and Political Uses. Yearbook for Traditional Music, Vol. 33. Canberra: International Council for Traditional Music, pp. 109-121, http://dx.doi.org/10.2307/1519635.

Giurchescu, Anca \& Torp, Lisbet 1991. Theory and Methods in Dance Research: A European Approach to the Holistic Study of Dance. Yearbook for Traditional Music, Vol. 23. Canberra: International Council for Traditional Music, pp. 1-10, http://dx.doi.org/10.2307/768392.

Haav, Margus 2009. Jaak Johansoni ja Silver Sepa tantsuetendus taastab hääbunud sidet. [Dance Production by Jaak Johanson and Silver Sepp Restores the Vanished Connection.] Postimees (newspaper), November 12. Available at http://www. postimees.ee/?id=187022, last accessed on August 2, 2013.

Hobsbawm, Eric 1983. Introduction: Inventing Traditions. In: Eric Hobsbawm \& Terence Ranger (eds.) The Invention of Tradition. Cambridge: Cambridge University Press, pp. 1-14.

Hoerburger, Felix 1965. Folk Dance Survey. Journal of the International Folk Music Council, Vol. 17, part 1, pp. 7-8.

Hoerburger, Felix 1968. Once Again: On the Concept of "Folk Dance". Journal of the International Folk Music Council, Vol. 20, pp. 30-32.

Honko, Lauri 1998 [1990]. Folklooriprotsess. [The Folklore Process.] Mäetagused: Hüperajakiri, Vol. 6, pp. 56-84. Available at http://www.folklore.ee/tagused/ nr6/honko.htm, last accessed on August 2, 2013. [Original: Hanko, Lauri 1990. Folkloreprosessi. Sananjalka 32, 1990, pp. 93-119.]

Hoppu, Petri 2004. Tantsufolklorism tänapäeva Soomes. [Dance Folklorism in Finland Today.] In: I. Rüütel (comp.) Pärimusmuusika muutuvas ühiskonnas 2. Töid etnomusikoloogia alalt 2. Tallinn: Eesti Kirjandusmuuseumi etnomusikoloogia osakond \& Eesti Rahvuslik Folkloorinõukogu, pp. 97-101.

Kaeppler, Adrienne L. 1989. Dance. In: E. Barnouw (ed.) International Encyclopedia of Communications 1. New York: Oxford University Press, pp. 450-454.

Kapper, Sille 2006. Tantsufolklorismist tänases Eestis. Folkloorse tantsu harrastamisest Eestis 1995-2005. [Dance Folklorism in Estonia Today. Folk Dance as a Hobby Activity in Estonia 1995-2005.] Master's thesis. Tallinn: Tallinna Ülikool.

Kapper, Sille 2008. Tantsufolklorismist tänases Eestis. [Dance Folklorism in Estonia Today.] In: M. Hiiemäe \& J. Oras \& L. Saarlo (eds.) Tonditosin. Tartu: Eesti Kirjandusmuuseumi Teaduskirjastus, pp. 24-52. 
Kapper, Sille 2009. Kuidas uurida eesti rahvatantsu tänapäeval? Teooriatest, meetoditest ja nende rakendamisest Eestis. [How to Conduct Research on Estonian Folk Dance Today?] Mäetagused: Hüperajakiri, Vol. 41. Tartu: Eesti Kirjandusmuuseum, pp. 75-98. Available at http://www.folklore.ee/tagused/nr41/kapper.pdf, last accessed on August 2, 2013.

Kapper, Sille 2010. Seest tuleb üks tants - tantsune muusik. Intervjuu Silver Sepaga. [The Dance Comes from Inside: A Dancing Musician. Interview with Silver Sepp.] Sirp (newspaper) No. 26, July 22. Tallinn: SA Kultuurileht. Available at http:// www.sirp.ee/index.php?option=com_content\&view=article\&id=10944:seest-tulebueks-tants--tantsune-muusik-\&catid=5:muusika\&Itemid=12\&issue=3305, last accessed on August 2, 2013.

Keelevara. [Languageware.] Available at http://www.keelevara.ee/teosed/seletav/, last accessed on August 2, 2013.

Krause, Katrin 2007. Rahvatantsu imago noorte ühiskonnas: uurimus 11-18-aastaste noorte seas. [Image of Folk Dance in Youth Society: Research among 11-18-YearOlds.] Master's thesis. Tallinn: Eesti Muusika- ja Teatriakadeemia.

Laugaste, Eduard 1963. Eesti rahvaluuleteaduse ajalugu: valitud tekste ja pilte. [History of Estonian Folklore Research: Selected Texts and Pictures.] Tallinn: Eesti Riiklik Kirjastus.

Laherand, Meri-Liis 2008. Kvalitatiivne uurimisviis. [Qualitative Research.] Tallinn: Infotrükk.

Luiga, Georg E. 1892. Rahwa tantsud. [Folk dances.] Olevik (newspaper) No. 31, p. 636.

Meiessaar, Maris 2009. Silver Sepp vahendab pärimustantsu keemilisi hetki. [Silver Sepp is Mediating Chemical Moments of Traditional Folk Dance.] Eesti Päevaleht (newspaper), November 14. Available at http://www.epl.ee/artikkel/482623, last accessed on August 2, 2013.

Mertelsmann, Olav 2003. Hariduse ja kultuuri ekspansioon süsteemi stabiliseerijana Eestis 1940-1956. [Expansion of Education and Culture as System Stabiliser in Estonia in 1940-1956.] Kultuur ja Elu (magazine), No. 3. Available at http:// kultuur.elu.ee/ke473_haridus.htm, last accessed on August 2, 2013.

Nahachewsky, Andriy 1995. Participatory and Presentational Dance as Ethnochoreological Categories. Dance Research Journal, Vol. 27, No. 1 (Spring), pp. 1-15, http://dx.doi. org/10.2307/1478426.

Nahachewsky, Andriy 2008. Folk Dance Revival Strategies. Ethnologies, Vol. 30, No. 1, pp. 41-57, http://dx.doi.org/10.7202/018834ar.

Nigu, Leenu 2011. Stomping Step Makes Us Estonian: Dancing the Pristine Ethos of a Nation. In: People Make Places: Ways of Feeling the World. SIEF Congress programme and book of abstracts. April 17-20. Lisbon: CRIA. Available at http:// www.nomadit.co.uk/sief/sief2011/panels.php5?PanelID=815, last accessed on August 2, 2013.

Põldmäe, Rudolf \& Tampere, Herbert 1938. Valimik eesti rahvatantse. [Selection of Estonian Folk Dances.] Tartu: Eesti Rahvaluule Arhiivi Toimetused 8.

Pomozi, Eda 2008. Setumaa tantsupärimusest Euroopa tantsuajaloo kontekstis. [Dance Traditions of Setumaa in the Context of European Dance History.] In: M. Hiiemäe \& J. Oras \& L. Saarlo (eds.) Tonditosin. Tartu: Eesti Kirjandusmuuseum, pp. 129-159. 
Preston-Dunlop, Valerie 1998. Dance words. Amsterdam: Harwood Academic Publishers.

Preston-Dunlop, Valerie 2006. Looking at Dances: A Choreological Perspective on Choreography. Ightham: Verve.

Rändur, V. P. 1933. Eesti omapärase tantsu uuestisünd. [Rebirth of Original Estonian Dance.] Postimees (newspaper), December 9, p. 6.

Raudkats, Anna 1926. Eesti rahvatantsud. [Estonian Folk Dances.] Tartu: Postimees. Royce, Anya P. 2002. The Anthropology of Dance. Alton: Dance Books Ltd.

R. S. 1932. Stiliseeritud rahvatantsud "Vanemuises". [Stylised Folk Dances at Vanemuine Theatre.] Postimees (newspaper), May 27, p. 5.

Russow, Balthasar 1993. Liivimaa kroonika. [The Chronicle of Henry of Livonia.] Tallinn: Hotger.

Rüütel, Ingrid 1987. Folkloor ja tänapäeva kultuur. [Folklore and Contemporary Culture.] Kultuur ja Elu (magazine), No. 5, pp. 11-15.

Rüütel, Ingrid 2004. Pärimusmuusika tänapäeva ühiskonnas. [Traditional Music in Contemporary Society.] In: J. Ross (comp. \& ed.) \& K. Maimets (ed.) Mõeldes muusikast: sissevaateid muusikateadusesse. Tallinn: Varrak, pp. 220-243.

Rüütel, Ingrid 2009. Kihnu pärimustantsud minevikus ja tänapäeval. [Traditional Dances of the Kihnu Island, Estonia.] Mäetagused: Hüperajakiri, Vol. 41, pp. 53-74. Available at http://www.folklore.ee/tagused/nr41/ryytel.pdf, last accessed on August 2, 2013.

Särg, Taive 2002. Rahvamuusika mõiste kujunemisest “rahva”teaduste ja musikoloogia vahel. [On the Formation of the Concept of Folk Music between 'Folk'-Sciences and Musicology.] In: T. Ojamaa\& I. Rüütel (comps. \& eds.) Pärimusmuusika muutuvas ühiskonnas 1. Töid etnomusikoloogia alalt 1. Tartu: Eesti Kirjandusmuuseumi etnomusikoloogia osakond, pp. 9-44.

Särg, Taive 2004. Mis on eesti rahvamuusika? [What is Estonian Folk Music?] In: J. Ross (comp.), J. Ross \& K. Maimets (eds.) Mõeldes muusikast: sissevaateid muusikateadusesse. Tallinn: Varrak, pp. 125-159.

Särg, Taive 2005. Rahvamuusika mõiste ja kontseptsiooni kujunemisest Eestis. [On the Formation of the Concept of Folk Music in Estonia.] In: T. Ojamaa (comp.) \& T. Särg \& K. Labi (eds.) Pärimusmuusikast popmuusikani. Töid etnomusikoloogia alalt 3. Tartu: Eesti Kirjandusmuuseumi etnomusikoloogia osakond, pp. 13-48.

Särg, Taive 2010. Ehedus mitut moodi: rahvamuusika ahtusest pärimusmuusika avarustesse. [Different Authenticities: From the Narrowness of Folk Music to the Spaciousness of Traditional Music.] Keel ja Kirjandus (magazine), No. 8/9, pp. 639-654.

Särg, Taive \& Johanson, Ants 2011. Pärimusmuusika mõiste ja kontseptsiooni kujunemine Eestis. [Development of the Term and Conception of the Traditional Music in Estonia.] Mäetagused: Hüperajakiri, Vol. 49. Tartu: Eesti Kirjandusmuuseum, pp. 115-138. Available at http://www.folklore.ee/tagused/nr49/parimusmuusika. pdf, last accessed on August 2, 2013.

Shay, Anthony 2002. Choreographic Politics. State Folk Dance Companies, Representation and Power. Middletown: Wesleyan University Press.

Statutes 2012. Eesti Pärimusmuusika Keskus. [Estonian Traditional Music Center.] Viljandi: EPMK. Available at http://www.folk.ee/en/Introduction/Statutes, last accessed on August 2, 2013. 
Tampere, Herbert 1962. Eesti rahvatantsu ajaloost. [On the History of Estonian Folk Dance.] Tallinn: Eesti NSV Rahvaloomingu Maja.

Tampere, Herbert 1975. Eesti rahvapillid ja rahvatantsud. [Estonian Folk Music Instruments and Folk Dances.] Tallinn: Eesti Raamat.

Tavast, Arvi 2004. Mõiste mõiste: tähendusteooriate mõju oskuskeelepraktikale. [Concept of Concept: Influence of Theories of Meaning on Terminology Practice.] In: Rahvusvaheline terminoloogiakonverents "Eesti oskuskeel 2003", 10. ja 11. oktoobril 2003. Ettekanded. [Terminology Conference Estonian LSP 2003.] Tallinn: Eesti Keele Sihtasutus, pp. 7-18.

T. L. 1935. Elmerice Partsi lastetantsud. [Children's Dances by Elmerice Parts.] Postimees (newspaper), April 12, p. 7.

Tõnnus, Richard 1991. Anna Raudkats oma ajas. [Anna Raudkats in Her Time.] Tallinn: Eesti Raamat.

Toomi, Ullo 1947. Valimik eesti rahvatantse. [Selection of Estonian Folk Dances.] Tallinn: Ilukirjandus ja Kunst.

Toomi, Ullo 1953. Eesti rahvatantsud. [Estonian Folk Dances.] Tallinn: Eesti Riiklik Kirjastus.

Torop, Kristjan 1992. Endisaegse Virumaa tantsuvõimalused ja tantsud. [Dance Opportunities and Dances in Historical Virumaa.] In: I. Rüütel (comp. \& ed.) IdaVirumaa rahvakultuurist. Tallinn: Virumaa Fond, Eesti TA KKI folkloristikaosakond, pp. 132-147.

Torop, Kristjan 1995. Kontratantsud. [Contra Dances.] Tallinn: Rahvakultuuri Arendusja Koolituskeskus \& Eesti Keele Instituut.

Torop, Kristjan 2008 [1966]. Eesti rahvatantsu oskussõnastik. [Glossary of Estonian Folk Dance Terminology.] Ü. Feršel (ed.). Tallinn: Rahvakultuuri Arendus- ja Koolituskeskus.

Väike 1937 = Väike entsüklopeedia. [Small Encyclopedia.] R. Kleis (chief ed.). Tartu: K./Ü. Loodus.

Vissel, Anu 1999. Ülevaade varasematest töödest eesti rahvatantsu kogumisel ja arhiveerimisel Eesti Rahvaluule Arhiivi materjalide põhjal. [Overview of Earlier Works on Collecting and Archiving of Estonian Folk Dance, Based on Estonian Folklore Archives.] In: Rahvatantsu uurimine: arhiivid, meetodid, teooriad. Viljandi: Viljandi Kultuurikolledž, pp. 54-60.

Vissel, Anu 2004. Rahvatantsu asendist eestlaste kultuuripildis ja harrastustes. [The Position of Folk Dance in the Culture and Hobbies of Estonians.] In: I. Rüütel (comp.) Pärimusmuusika muutuvas ühiskonnas 2. Töid etnomusikoloogia alalt 2. Tartu: Eesti Kirjandusmuuseumi etnomusikoloogia osakond \& Eesti Rahvuslik Folkloorinõukogu, pp. 109-127.

VS 1997 = Aassalu, Heino \& Luht, Pille \& Torop, Kristjan (comps.) Vanad seltskonnatantsud. Valimik XX sajandi I poole seltskonnatantse. [Old Ballroom Dances. Selection of Social Dances from the 1st Half of the 20th Century.] Tallinn: Rahvakultuuri Arendus- ja Koolituskeskus. 


\title{
MOTIVATIONAL UNDERPINNINGS OF ESTONIAN FOLK DANCE PRACTICES AMONG THE ESTONIAN DIASPORA OVER TIME
}

\author{
Eha Rüütel, Iivi Zajedova, Angela Arraste
}

\begin{abstract}
This article is a part of a wider research on Estonian folk dance, aiming to map the emergence of folk dance groups and to study the practices and role of folk dance among the Estonian diaspora. The article sets out to explore incentives contributing to intergenerational transmission of Estonian folk dance tradition. 54 interviews ( 21 men and 33 women aged 38 to 87 ) were carried out with Estonians living in Australia, Canada, Germany, Great Britain, Sweden and the United States. The analysis of the interviews is based on two research questions: 1) What incentives have guided Estonians' folk dance activity in historical perspective from World War II until today? 2) What qualities originating in Estonian folk dance have motivated people to carry on Estonian folk dance practices? The principles of grounded theory were used in the analysis of interviews. The article discusses the results of two sets of analyses. Motivational changes in folk dance as a leisure pursuit have brought into focus three historical periods of folk dance transmission. Incentives originating from dance and dancing (selfexpression, self-determination, cooperation, emotion, physical training) and the external qualities accompanying dance and dancing (socialising, 'Estonianness', tradition) are discussed in the context of continuity of Estonian folk dance tradition among the Estonian diaspora.
\end{abstract}

Keywords: folk dance, Estonian diaspora, leisure activities, self-determination, motivation, cultural transmission

\section{INTRODUCTION}

In many written works that describe expatriate Estonians, folk dancing has been mentioned as one of their leisure activities (Kokla et al. 1956; Kool 1999) and therefore many publications that have come out abroad have listed folk dance groups of Estonians and their activity in different countries (Purje \& Varangu 1984; Jõe 1985; Kangro 1976). This article aims to give an insight into the continuity of folk dancing and the factors facilitating it among the Estonian diaspora. An important background factor was the popularity of folk dance as a leisure pursuit during the period of Estonian independence before World War 
II. Schools and temperance societies had an important role in popularising folk dance practice. The roots of Estonians' folk dance hobby reach back into history. The folklore studies of Põldmäe and Tampere (1938) refer to men's prebattle ritual dance in the 12th century and recreational dancing (dancing for pleasure) in the second half of the 19th century at swinging sites, communal work events, village parties and weddings. In the early 20 th century it became habitual to perform folk dance as a part of party programmes, whereas dance functioned as a means of communication between the audience and performers. An increase in the popularity of group dancing gave rise to the introduction of more interesting staging techniques. As a result, in the years 1904 to 1926 a performance-focused orientation developed in the Estonian amateur folk dance. Aassalu (1999: 4) emphasises the landmark event in the Estonian folk dance movement - the Evening of Indigenous Culture in 1926. Its typical features also characterise modern dance celebrations (Arraste 2009). It is maintained that the Estonian tradition of folk dance celebrations ${ }^{1}$ was initiated by the First Estonian Games ${ }^{2}$ held in 1934. Thus, before World War II, folk dance had developed into an appreciated area of activity and a popular leisure pursuit, and collecting dance descriptions and methods had started. Kangro ${ }^{3}$ (1976) views the ancient tradition of Estonian folk dancing and its rich repertoire of more than 200 old folk dances as an internal precondition for the continuity of folk dancing as a leisure activity. Anna Raudkats, a promoter of folk dance, on whose initiative folk dance became an essential part of physical education classes at school, viewed dance as a pleasant pastime, which made dancers forget their daily problems and developed the feeling of togetherness in them (Raudkats 1926; cited in Vissel 2004). Amateur dance pursuit was considered very important, because it deepened the love for ancestors' intellectual creation and at the same time kept people healthy, improving their physical and mental stamina, stimulating their emotions and giving them strength (Põldmäe \& Tampere 1938: 50).

The Estonians who fled their homeland as war refugees during World War II, left mainly for Germany and Sweden, where they were concentrated in camps. Many Estonians later moved on to other European countries, America and Australia. For most of those who fled to Germany, refugee camps provided their first shelter and housing for several years. There were refugee camps also in Sweden but the length of stay there was short - only a month or two.

Due to the war and the changing political situation, it was professionally and socially active people who left Estonia. However, only few people were engaged with everyday work at refugee camps, which left plenty of leisure time. According to Russell (2009), the contemporary meanings of leisure can be categorised in three ways: as free time, as a recreational activity, or as a state of mind, a 
special attitude or feeling. Leisure as a state of mind is an entire lifestyle that produces meaningfulness in life, self-expression, and self-actualisation. McGill (1996) states that leisure helps to describe how people view themselves; active leisure involvements give a stronger sense of who they are and enhance their sense of belonging.

The above allows for creating a connection with self-determination theory (Deci \& Ryan 2000, 2008; Ryan \& Deci 2000), which assumes that people are by nature active and self-motivated; however, social conditions and processes have an impact on what people do and how they feel while acting, and, as a consequence of acting, social environment either supports, directs or thwarts that nature. Social contexts that facilitate the satisfaction of three basic psychological needs - to feel competent, autonomous, and related to others - support people's inherent activity, promote more optimal motivation, and yield most positive psychological, developmental, and behavioural outcomes (Ryan \& Deci 2000; Deci \& Ryan 2008).

As in the pre-war period folk dance practice had developed rapidly and folk dance skills were a part of education, there were many Estonian refugees who had relevant experience and were able to organise and lead folk dance groups. Little professional engagement made people look for activities to fill their time and created an opportunity to continue pursuits that had become habitual at home, and thus to maintain continuity, give meaning to the time spent at refugee camps and sustain hope to return to homeland. Therefore Estonians residing at camps filled their lifestyle-related leisure with cultural and social activities (Kokla et al. 1956: 88).

As an embodied leisure practice, dance has been described by the capacity to create cultural identity (Shoupe 2001; Snape 2009) and, as Snape (2009) emphasises, in developed countries folk dance tends to be performed not only for its intrinsic enjoyment but also because the dancers engage, to varying degrees, in the preservation or re-creation of a national or regional tradition. However, active participation in Estonian folk dance activities in the refugee camps was obviously due to the fact that many people had learned folk dance before. Revill (2004: 8), while analysing folk dance pursuit and relying on a set of personal reminiscences drawn from his own experience of learning French folk dance, attaches importance to dancers' hard work, which precedes the dance-related self-expression and enjoyment of movement:

[...] practising for the moment at which their activities are miraculously transformed into unreflected habit. [...] That moment is charged as an originary and foundational moment from which a more truthful cultural practice emerges. 
Revill emphasises connections between body culture, history and social values, and the free and authentic interaction taking place while dancing and through the medium of dance.

Dancing profoundly socializes the body, from the embarrassment of excess perspiration to the blur of self-contained exhibitionism as couples pirouette at speed around the room confident in their mutual trust. The dancing body communicates and speaks volumes in response to others. (ibid.: 9)

While describing the spread of folk dance hobby among Estonian war refugees, Kangro (1976) highlights as the most important in the specific situation the energy, enthusiasm and buoyancy as well as trust in the future, to dance, exercise and take part in physical activity in spite of the challenging status of being a refugee. In this process, the performance of folk dance acquires a layered meaning and becomes a conscious symbolic act, representational of something beyond its immediate occurrence (Snape 2009).

This allows us to state that in spite of the drastic political and psychological context and ascetic conditions of refugee camps, these circumstances mobilised the Estonian community and maintained the folk dance tradition. Kangro (1976) emphasises that, in addition to the internal prerequisites, favourable external conditions were needed, i.e., sufficiently compact groups of people living reasonably close to each other, and the availability of rooms for meeting, practicing and performances. Communal activity also supports general and personal coping. Those who enjoy a high level of social support experience less adverse effects of stress (Cohen 1991). On this basis, the folk dance practice of expatriate Estonians can also be considered as an activity promoting health and well-being in terms of physical training, social support network and self-determination.

The current article is a part of a wider research on Estonian folk dance, aiming to map the emergence of folk dance groups and to study the practices and role of folk dance among the Estonian diaspora. The aim of the article is to describe general motivational underpinnings contributing to the survival of Estonian folk dance tradition among the Estonian diaspora in Australia, Canada, Germany, Great Britain, Sweden and the United States. The analysis of the interviews carried out with Estonians is based on two research questions: 1) What incentives have guided Estonians' folk dance activity in historical perspective from World War II until today? 2) What qualities of Estonian folk dance have motivated people to continue dance practices? 


\section{METHOD}

\section{Participants}

First contacts with local Estonians in six countries (Australia, Canada, Germany, Great Britain, Sweden and the United States) were established through Estonian societies and Estonian folk dance groups. During the interview process and conversations, information about other people possibly involved in folk dance was obtained. Altogether, 54 interviews were conducted with 21 men and 33 women from three generations of Estonians during the years 2006-2010: four living in Australia (one man and three women aged 48 to 71); four in Canada (three men and one woman aged 50 to 87); thirteen in the Federal Republic of Germany (six men and seven women aged 46 to 85); seven in Great Britain (one man and six women aged 36 to 84); eleven in Sweden (six men and five women aged 28 to 80 ), including two Swedish Estonians who had returned to Estonia; fifteen interviews were conducted with Estonians from the United States (four men and eleven women aged 52 to 76), including one who currently lives in Estonia.

\section{Data collection and analysis}

Unstructured interviews and conversations were used. All interviews were videotaped and transcribed, maintaining, as far as possible, without loss of meaning, the original form of the text and use of language. To present the results, the following symbols have been used to refer to interviewees: initials and, in brackets, the age of the interviewee at the time of the interview, gender (F - female, $\mathrm{M}$ - male) and country of residence (A - Australia, C - Canada, G - Germany, GB - Great Britain, S - Sweden, USA - the United States of America).

The principles of grounded theory (Glaser \& Strauss 1967; Strauss \& Corbin 1990) were used in the analysis of the transcribed texts. Grounded theory strives to arrive at a theoretical understanding of psycho-social phenomena, which is grounded in the data collected from the lives and contexts of the participants (Forrester 2010). Grounded theory starts with details of individual cases and uses the logic of induction to develop a theory that holds true for those cases (ibid.). The researchers started with independent open coding of the interviews and creating country-based categories. The results of the analysis were compared and, if necessary, interviewees were asked clarifying questions. Grounded theory allows for starting the collection of data to describe the researched phenomenon without a prior theoretical approach. Therefore the literary sources 
given in the introduction of this study constitute the materials used to describe the context rather than the theoretical basis of this research.

The first study was carried out in Germany, which was the first stopover for Estonian refugees, from which they moved on to other countries, and described the categories related to Estonian folk dance in this country (Zajedova \& Rüütel 2009; Zajedova et al. 2009).

I. Places where people danced: a) refugee camps, b) summer camps / summer homes and scout camps, c) folk festivals, d) performances, c) political demonstrations.

II. Motives (what made people dance): a) hobby continuity, b) living together in a refugee camp, c) entertainment, d) a desire to teach folk dance to children.

III. Activities of folk dance groups (how folk dance groups operated): a) activity, b) support, c) groups and interests, d) benefits of folk dance.

The second step was a comparative research of Germany and Sweden (Zajedova \& Rüütel 2012). The study revealed aspects contributing to contrasting situations - the demise of folk dance groups in Germany and the sustainability of folk dance activity in Sweden. In both countries the set-up and organisation of folk dance groups relied largely on enthusiasts and participation in folk dancing was used as a good possibility for bringing young people together. However, certain differences can be observed. In Germany folk dance activity seemed to be influenced to a large extent by cultural-political objectives, the topicality of which diminished when Estonia regained its independence. In Sweden, the popularity of folk dance seems to have been maintained due to the modernisation of the dance style, which became more choreographed and show-like, and thus more interesting and attractive to young people.

In the third stage of the study the German and Swedish interviews were complemented by the ones conducted in Great Britain, Canada, the United States and Australia, and the cultural celebrations that had taken place in different communities of the Estonian diaspora were mapped on the basis of literary sources and archival materials (Arraste \& Zajedova \& Rüütel 2011). It described the dimension of cultural celebrations (local, regional, worldwide), changes in the dimension and diversification due to local developments as well as wider spread of information after Estonia regained independence in 1991. The study of cultural celebrations clearly showed that although after World War II the Estonian nation was geographically fragmented into Estonians abroad and Estonians at home, their major celebrations belong to a coherent whole and carry the continuity of the Estonian national culture. 
This article reflects the fourth stage of the research and focuses on the motivational underpinning of Estonian folk dance practices. Since the interviews included a wider range of topics than the objectives of this article, the first step was to identify conceptual categories relevant to the research questions of the current article. Through axial coding individual categories were grouped into the main categories of motives, first in a historical perspective and, second, based on the qualities of Estonian folk dance.

\section{RESULTS}

\section{Changes in folk dance as a leisure pursuit over time}

The analysis of the interviews reveals three periods, different in their circumstances, objectives and incentives. The first period covers the time when the Estonians who had emigrated lived in refugee camps in Germany and Sweden. The second period includes the time from the liquidation of the camps in 1949 to the restoration of independence of Estonia in 1991. The third period views today's folk dance activities.

\section{Period I: Folk dance in refugee camps as a part of daily life}

The initial stopover for Estonian war refugees was refugee camps in Germany and Sweden. In Sweden Estonian refugees lived in these camps for a short period only and were distributed across the country, from where in the 1950s the majority settled in towns (Kokla et al. 1956). The stay of the refugees in German refugee camps was longer and the camps were acting as a meeting place for those Estonians who lived outside.

GB (63F, G, not a former refugee camp resident): There were masses of them, [...] who lived in the camps. [...] Some were in the suburbs of Hamburg, some were a little further. [...] We always met up with them. They invited us and when there was a Christmas party, the anniversary of the republic, or a summer festival, we always went and sang and danced. [...] In Oldenburg there were also big camps and there they lived together and danced, sang together.

$\mathrm{LP}(85 \mathrm{~F}, \mathrm{G})$ : We had a young man who [organised] gatherings of refugees for at least twice a month, I think. There we danced and sang and baked cakes and everyone had to do something. 
Community life included dancing as a regular activity and the camps became the first places for the formation of folk dance groups.

JK (81M, G): In the camps, everywhere where there were Estonians [...] people sang and danced. [...] Where we lived, well, the houses were very close to each other; it was such a primitive communal space. We gathered there and practised. [...] It made us work harder, to keep body and soul together, [...] this means, at weekends, then.

Research revealed that the activists and leaders of folk dance did not necessarily have any special training, but that it was rather the desire to dance and teach folk dance to their children that stimulated them to learn and study dances and teach them to other people.

MB (68F, A): All that boy scouts and girl guides' thing, folk dance and choirs - they had strong tradition in refugee camps. Some men went to work, but not all. Women very seldom worked. So there was plenty of free time to teach young people folk traditions. [...] Then, when they spread all over the world, they started folk dance groups and choirs, the Scouts and Guides' and sports groups.

The repertoire seemed to vary according to the skills and knowledge of the leaders of the dance groups. First, folk dances were practised from memory, because the representatives of the older generation had learned folk dances at school in Estonia. After the publication of Ullo Toomi's" (1953) book "Estonian Folk Dances", this was used to teach folk dance in Estonia and abroad.

JK (81M, G): I came across this thing at a pretty young age indeed. I finished primary school in Viru-Jaagupi and the last grades I attended in Viru-Jaagupi when I was 11 to 14 years old, and they taught folk dance there already at that time.

VJ (61F, G): I had an aunt [...] She was teaching Estonian dance [in Hamburg], but these were not proper folk dances. It was a little bit like [...] done her own way.

GB (63F, G): We had that book [Ullo Toomi's "Estonian Folk Dances"] and we took our repertoire as we were told. [...] We learned and mastered them. [...] Well, there was always someone who knew [...] how it went. 


\section{Period II: Folk dance as a carrier of the continuity of Estonian identity}

The second period is related to the realisation of people that the expected imminent return to Estonia was not going to happen and it was necessary to organise their lives for an extended stay abroad. This period is also associated with the movement of Estonians from their initial stopovers to the United States, Canada, Australia, and Great Britain. The keywords defining the second period are Estonian communities passing Estonian culture on to children, and folk dance as national self-expression and part of national self-determination.

Estonians considered it important to create Estonian communities in their countries of residence; Estonians in America emphasised the term "Estonian village".

$\mathrm{AE}$ (86F, GB): [...] when they came here, a large group of Estonians [...] there was a choir, a dance festival. It was all like ... like a small Estonia. The same as in Germany and Canada and everywhere else ...

VA (76M, USA): Well, there was Estonian culture [...] there had to be everything in the Estonian village, folk dance and choirs.

The interviews highlighted that folk dancing was a popular leisure activity among expatriate Estonians; popular enough to find a sufficient number of interested people to join folk dance groups. Practice and rehearsals took place on a regular basis.

Children's folk dance groups were formed in order to pass on knowledge and traditions to the next generation. In Germany, interviewees devoted considerable attention to children and youth summer camps, in which Estonian children communicated with each other in the Estonian language and where they also learned folk dances. Estonian folk dances were taught on a regular basis at Estonian schools in Australia, Canada, Great Britain, Sweden and the United States, ${ }^{4}$ and folk dance was integrated into the teaching of Estonian culture.

MB (68F, A): During my school days I lived in an English-speaking world from Monday to Friday. From Friday evening to Monday morning I lived in an Estonian-speaking world with the continuation school, the Scouts and Guides and gymnastics and folk dance. But it wasn't an official group as such. This was just part of our national education.

Performances of folk dance groups allowed to introduce Estonians and Estonian culture to the local people in the countries of residence. Through folk dance Estonians expressed their national character, defined themselves in their new 
cultural environment. The performances took place during 1) the local events of the Estonian community, which were mainly related to Estonian holidays or those of the country of residence, events introducing and uniting the Baltic nations as well as other nations on a wider scale; 2) national reunions of expatriate Estonians (e.g. Estivals in Sweden, West Coast Days in the United States); 3) worldwide festivals for expatriate Estonians (ESTO). Before performances, practice sessions were more frequent and more attention was paid to the accuracy of the presentation. During performances Estonia and Estonians were introduced, speaking about who they were and why they were there.

HA (50M, C): [...] In Canada, be it a multicultural day, or be it ESTO days, there was always a procession in the centre of the town related to it. We were walking with flags and posters, wearing national costumes, Scout uniforms or whatever groups had come.

The performances could also acquire strongly political undertones:

LP $(85 \mathrm{~F}, \mathrm{G})$ recalls: Choirs and folk dance [...] that was our weapon. [...] We were not allowed to do politics in Germany but we could do cultural politics and by means of that we still managed to introduce our culture, our songs and dances, our Estonian language. [...] I hold that this was our weapon for restoring independence, our contribution.

The second period is characterised by actively functioning Estonian communities and the preserving and maintaining of the Estonian language and culture. In passing down the Estonian traditions to children, learning the language was of primary importance. The teaching of folk dance was integrated into the general instruction on Estonian culture, and children acquired skills in folk dance and folk singing at an early age, in summer camps and Estonian schools.

\section{Period III: Folk dance as an artistic-cultural self-expression in the multicultural environment}

The third period began when Estonia regained independence in 1991. It was possible to freely visit Estonia, participate in dance festivals, communicate with folk dancers, and learn from Estonian folk dance leaders. Joint folk dance study days and seminars were organised. Judging by the interviews, it seems that folk dance is not so much an integrated part of the general national culture and being an Estonian. Today's folk dancers are the third generation of Estonians whose home language is often not Estonian, and non-Estonians interested in folk dance are included in the groups, hence the role of folk dance in preserving 
the Estonian language is no longer valid. Discovering Estonia by the Estonians of the younger generation seems to occur on a wider scale than just national culture and does not necessarily involve folk dance activities.

The emphasis in Estonian folk dance seems to have shifted on artistic selfexpression. To preserve and develop that, motivated dancers are needed.

LT (51F, USA): The numbers in new generations get smaller all the time [...] I hope they (Americans) like our company, [...] and we are so grateful when they come [and dance]. But if there were only Estonians, if there were four couples of us, we would dry up very rapidly.

Changes have also taken place in the teaching of folk dance. Summer camps for dance leaders are organised and active communication takes place between Estonian folk dance professionals all over the world.

LT (51F, USA): For the first time the dance leaders' group met in 1995. [...] I've been to two summer camps of dance leaders. [...] And now I have several dance leaders in Estonia, from whom I can ask when I need help [...] and I have some people to discuss my ideas with. This exchange of ideas [...] I'm very grateful for that.

The third period covers the functioning of Estonian communities and their cultural traditions in the context of openness created by Estonia's regained independence and rapidly developing information technology, which makes it easy to maintain and establish contacts and participate in Estonian culture. The earlier traditions of passing down cultural phenomena do not fit for the changed circumstances, therefore this period seems to be characterised by a retune to multiculturalism. The following analysis of the incentives of the Estonian folk dance activity is an attempt to open these background factors that in the current conditions support the continuation of Estonian folk dance in the expatriate Estonian communities.

\section{Incentives for Estonian folk dance activity}

The following analysis reveals the context of folk dance performance and interviewees' relationship with folk dance, leaving aside the aspects of repertoire, music and choreographic expression, which have been described in the earlier published articles (Arraste \& Zajedova \& Rüütel 2011; Zajedova \& Rüütel 2009, 2012; Zajedova et al. 2009). In the current analysis the Estonian folk dance is viewed in its widest sense, based on the interviewees' personal definition and relationship with folk dance. Thus, the authors do not take on board the problem of defining folk dance, which is seen by the researchers of the field as 
a complicated issue due to the changes in the dance culture and, even more, in the way of thinking (Kapper 2009). At the same time, it is probably important to give here the description of the nature of Estonian folk dance that appears on the webpage of the non-profit association Estonian Traditional Music Centre:

Estonian folk dance has been viewed as collective, restrained and dignified, striving for no external effect. There are no big leaps in the dances or fast and varied activities of arms and legs. The body is usually kept straight and there are no hip movements, as is characteristic of many modern dances. Arms are usually not raised above the hip level; movements requiring grace and flexibility, such as foot stretches, deep bends or high leg lifts, are unknown. (Eesti tantsu iseloom 2009)

\section{Qualities originating from dance and dancing}

Cultural-national self-determination. In the process of learning folk dances, knowledge was also acquired about Estonia, the regions that the dances came from, and dance traditions; the history of Estonia was learned through dances of various periods. This gave material for reflection about one's belonging, one's roots. Large festivals provided Estonians with an opportunity to explain and show Estonian culture to the audience.

TA (48F, A): I think that everyone needs to know where he or she comes from. [...] It is very important for every person. [...] In recent years we've been trying more and more to perform in Australian multicultural events, National Folk Festival has been the largest, [...] to perform Estonian dance, because it's a bit different, and to place Estonian culture in the multicultural image of Australia. Estonians also belong to Australia, we have something that is original, that is different and interesting. That while being Australians we are also Estonians...

RM (59F, C): [...] and friendship and interest in Estonia, and you're learning not only dances, you're learning Estonian music, Estonian geography through realising where these dances have come from. Again, in Toomi's ${ }^{5}$ book it's been very accurately described where a dance comes from, and the pride - to wear the national costume with pride. [...] We knew exactly where the national costume of each of us came from.

Dance as a language of self-expression includes codes, such as 'dance as a type of culture', 'tool of communication' and 'mediator of culture'. The interviewees 
attached importance to dance as a universal language and emphasised that dance is a national activity in which one can be involved even without any knowledge of the Estonian language.

TK (52F, USA): I've always thought that heritage is a much wider thing. [...] Expatriate Estonians may have limited this understanding a bit too much. That it had to be based on the language. But we had folk dance that wasn't directly based on the language. So then, because it survived, because this pleasure survived, I think it is another example that culture can be mediated in different ways. [...] And through that I've learned to dance so well that I enjoy it.

MB (68F, A): We have many young people, especially in Sydney, who don't speak a single word in Estonian. But folk dance is such a national activity that you can engage in without knowing the language. I'm not surprised that folk dance is the part of our national activity that has survived best. When you've lost the language you can still dance.

Cooperation. The category of cooperation includes group qualities outlined in the interviews, such as 'holding together', 'the group feeling', and 'joint performances'.

TK (52F, USA): When I grew up, I danced because I wanted to do it. Then we developed this really nice feeling of the group, the group feeling. There was the pride that we were able to be in tune with each other, that we were good at it.

Emotion. As the majority of expatriate Estonians had danced since childhood and they knew how to dance, positive emotions accompanying performances were emphasised; the participants enjoyed dancing, folk dances were described as merry dances. The performances offered the audience the pleasure of dance patterns.

TK (52F, USA): I think it produced beauty in the old, ancient sense. It was fun and joy of movement with music. Sense of beauty through the costumes, dance patterns, and working together. It produced the beauty you can only find in folklore.

MB (68F, A): Folk dance was fun, a nice thing. It wasn't like we had to dance absolutely perfectly. When you're young, you remember all the movements. And when you're dancing with your friends, and it's your weekly activity, and there's a performance approaching - it's great. I cannot think of a better time. 
Physical activity. The interviewees also emphasised the physical quality of dance practice - 'good feeling', 'physical fitness', and 'body control'.

AS (87M, C): [...] two things: for fun and physical training and that was probably one of the most important things, that physical training, wasn't it? And [body] co-ordination, of course. So that you're able to move your hands and feet.

MB (68F, A): But in our time we simply danced and I was very proud of it that my partner and I, that we were the champions of South-Australia, that we danced the Jooksupolka $a^{6}$ for at least 22 times around the hall of the Estonian House without getting breathless. [...] It was physically very rewarding.

\section{The external qualities accompanying dance and dancing}

The external qualities of dance and dancing are related to communication and the circle of people that met during dance practice sessions.

Socialising. Holding together and supporting each other were very important for the Estonian war refugees in order to cope in their countries of residence. More recent folk dance pursuit is largely viewed as an opportunity for entertainment and socialisation, meeting with the people you know, making new acquaintances. As an important stimulus, finding an Estonian partner was mentioned.

AR (61M, S): Let's say that among Estonians in Gothenburg those who were active often participated in several organisations and kept meeting, so to speak, under different 'umbrellas'. One evening we would meet as part of a student society, the next day as part of a sports society and on the third evening we were folk dancers.

RJ (50F, GB): The friends I made there have been my friends ever since. [...] Just that it was fun meeting other young Estonian people and do something together. Indeed, we had always so much fun and I was really looking forward to these practice sessions.

'Estonianness'. This category describes the national-historical context of Estonian dance and the perception of one's roots through dance, as well as knowledge about, experience of and connection with Estonia. 
IW (62F, GB): It maintained Estonianness in me. And that's why I think I'm much more interested in Estonia and dance festivals and folk dance and folk music than I would've been without doing it in my childhood.

RL (56M, S): To me it gave a lot, to be able to do things with other Estonians. To do Estonian things, so to say.

Tradition. The ability to dance and practice Estonian folk dance was viewed as an Estonian tradition that belongs to the daily life of Estonians and constitutes a part of the overall education.

PS (55M, GB): In the old days, before Estonia became free, it was a way of keeping the traditional life [...] It's like keeping it going for the people who hadn't gone back to Estonia or who'd left before the war or during the war. It's keeping that tradition going for them... Things have changed in England a lot during years, since Estonia became free, but we still keep that old tradition going. [...] It's a good feeling to meet other European Estonians. A good feeling.

$\mathrm{MB}$ (68F, A): [...] we didn't seem to have that choice. It never even occurred to me not to do that. We had a very nice group. We were all together in the continuation school, we were all in the Scouts and Guides...

AR (61M, S): Folk dance belongs to the general education of intelligent Estonians.

LT (38W, GB): I like it so much. I like watching and dancing. I don't want it to die off.

The incentives for Estonian folk dance activity are summarised in the two figures below. The analysis of the personal incentives of the transmission of Estonian folk dance practices reveals two categories (Figure 1).

Both categories seem equally important for the transmission (dancer's aspect) and preservation (teacher's aspect) of Estonian folk dance activity. Focusing on Estonian dance as a medium of identity and culture, we can present three main categories that emerged during the analysis of the interviews: interest in dancing, community (meaningful emotional relationships) and 'Estonianness' (knowledge about, experience of, the connection with Estonia) - the essential component that ensures the originality, the typically Estonian quality of Estonian folk dance (Figure 2). The language of Estonian folk dance serves as the mediator between generations. 


\section{Qualities related to Estonian folk dance}

Qualities originating from

dance/dancing:

- Self-expression through dance

- Cultural-national self-determination

- Cooperation

- Emotion

- $\quad$ Physical training

\section{Qualities accompanying}

dance/dancing:

- Socialising

- 'Estonianness'

- Tradition

Figure 1. Qualities originating from dance and dancing and related qualities that underpin folk dance practices.

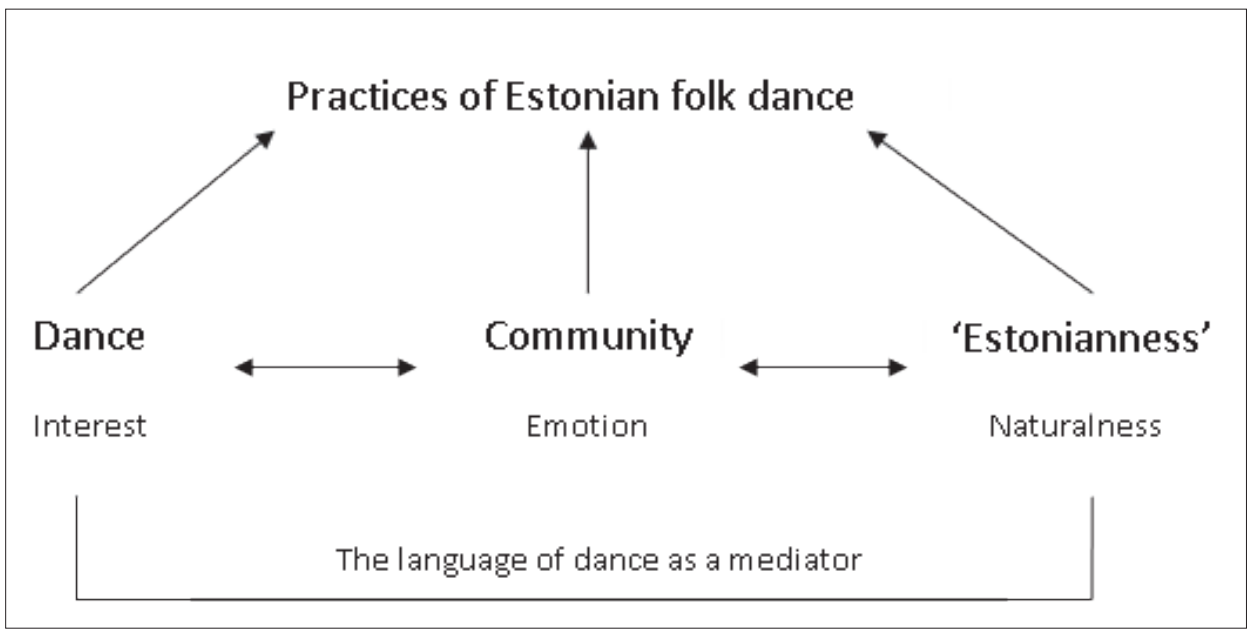

Figure 2. Main incentives underpinning the continuation of Estonian folk dance practices. 


\section{DISCUSSION}

The aim of this study was to explore the motivational underpinnings that have contributed to the survival of Estonian folk dance tradition in Australia, Canada, Germany, Great Britain, Sweden and the United States. A chronological analysis of the data revealed three periods. The first period covers Estonians' life in refugee camps in Germany and Sweden after World War II until 1949. The general incentive in that period, which also applies to folk dance, was starting life in the new countries of residence. The factors contributing to adopting folk dance as a leisure activity were: people's earlier experience of folk dancing for recreation, and the proximity and little employment in the camps that left people with plenty of free time. Priority was given to young people's national education, which also included folk dance. The interviews referred to the emotional side of folk dancing as an enjoyable social pastime. As Cohen (1991) has emphasised, social relations have a positive effect on well-being. Dance and music have been considered as directly "mood-inducing" activities (Argyle 1999). Thus folk dance seemed to have an important role as a physical activity and also an activity bringing people together and providing space for communicating, with an addition of aesthetic enjoyment from the colourful folk costumes. Thus the health-promoting role of folk dance observed by Kangro (1976) cannot be underestimated. Based on the identity-developing potential of leisure (Shoupe 2001; Snape 2009), the important effect that national cultural leisure activities in refugee camps had on cultural self-definition can be observed over time.

The main incentive for the second period lasting until Estonia regained independence in 1991 was the preservation of the continuity of 'Estonianness'. The interviews reflected responsibility for the transmission of Estonian culture, and especially the Estonian language. Folk dance was integrated in children's cultural education. In dance classes the Estonian language was spoken and thus learning Estonian dance also contributed to language acquisition. Folk dance allowed introducing Estonians' ethnic origin, expressing political views, and attitude towards the occupation of Estonia.

The third period that involves the past couple of decades is characterised by the fact that national borders are no longer a barrier between expatriate Estonians and Estonian culture in its diversity is available in many places in the world. Today dance-specific incentives dominate - self-expression through dance and professionalism in dance as well as the opportunity provided by the dance, which Revill (2004) points out as a language that combines culture, history and social values. 
However, there are considerably fewer people practicing Estonian folk dance than in earlier periods and, due to the change of generations, non-Estonians have joined folk dance groups. The need to preserve the Estonian language through folk dance seems no more the basic motive for folk dance activity, although the question of language has always been a sensitive contact area between the conservatism and rational practical behaviour of expatriate Estonians (Kõiva 2010).

According to the self-determination theory (Deci \& Ryan 2000, 2008; Ryan \& Deci 2000), it is important what people feel while acting. Behaving with full sense of volition and choice presupposes autonomous motivation, which comprises both intrinsic and well-internalised extrinsic motivation. We can provisionally define the qualities originating from dance and dancing (self-expression, self-determination, cooperation, emotion, physical training) as a source for intrinsic motivation and the external qualities accompanying dance and dancing (socialising, 'Estonianness', tradition) as internalised extrinsic motivation. In case external motives dominate, the importance of the dance component decreases and besides or instead of dance it is possible to find other activities fulfilling the same purposes and needs. When dance qualities dominate, the connection weakens with the wider socio-cultural context, which carries the traditions of Estonian folk dance and components of social recreation. Thus the interest in dance, folk dance community and 'Estonianness' in the meaning of knowledge, experience and connection with Estonia can be considered as the main carriers of the continuity of Estonian folk dance tradition.

\section{CONCLUSION}

The interviews revealed that Estonian folk dance is viewed as a traditional activity, which still belongs to the daily life of expatriate Estonians and is a part of being an Estonian. Folk dance as leisure activity supports people's need to belong, their self-esteem and importance as contributors to a group's success. In other words, as Põldmäe and Tampere put it: "Individual participation in group activities enabled to get the experience of perceiving the nature of mass as a whole while appreciating the role of an individual in human society" (Põldmäe \& Tampere 1938: 50). Apparently these were the reasons for many young and older people to dance in post-war years, when maintaining the ethnic identity and self-determination in a new cultural environment was important. This also explains why currently the number of people practicing Estonian folk dance has decreased. The opportunities for self-determination and belonging have 
expanded due to people having adjusted in the countries of residence and due to the improved connection with Estonia.

Focusing on personal incentives that have maintained the folk dance activity of expatriate Estonians over the years, this study reveals the variability of human motives, which sheds light on the multi-layered personal and social role of folk dance among expatriate Estonians.

\section{ACKNOWLEDGEMENTS}

We would like to express our gratitude to the expatriate Estonians who participated in our study and contributed to the successful completion of our research. This article reflects the results of the study carried out within the framework of grant No. 7231 of Estonian Science Foundation, "The original choreographic text and form of presentation of Estonian folk dances as fixed in audiovisual recordings".

\section{NOTES}

1 Estonian Song and Dance Festivals - large-scale festivals held every fifth year, assembling as many as 40,000 singers and dancers. In 2008, Estonian Song and Dance Festivals were inscribed in the Representative List of the Intangible Cultural Heritage of Humanity (originally proclaimed in 2003) (see http://www.unesco.org/ culture/ich/index.php?pg=00011\&RL=00087).

2250 folk dance pairs performed at the great gymnastics and sports festival in Tallinn in 1934, which has also been regarded as the first Estonian national dance celebration, and which by now has become a simultaneous event with our Song Festivals.

3 Bernard Kangro (1910-1994) was an Estonian writer and poet who formed the quintessence of exile literature.

4 The Estonian school was functioning in Stockholm during World War II and it still operates successfully. The Estonian school in Gothenburg was opened in 1960 but was shut down in 1994 due to lack of teachers and children. Estonians started educational life also in German refugee camps and later on in other countries, such as Australia, Canada, Great Britain, and the United States. Estonians mainly established Estonian Sunday and Summer Schools.

5 Ullo Toomi (1902-1983) was a teacher of Estonian folk dance in Estonia and authored a book entitled Eesti rahvatantsud (Estonian Folk Dances).

${ }_{6}^{6}$ Run-run-jump dance. 


\section{MANUSCRIPT SOURCES}

Interviews and field notes from Bocholt, Germany, 2006; Hamburg, Germany, 2007; Gothenburg, Sweden, 2007; Birmingham, UK, 2008; Tallinn, Estonia, 2008; Portland and Los Angeles, USA, 2009; Washington, USA, 2009; Annaberg, Germany, 2009; Toronto, Canada, 2007 and 2009, in the possession of authors.

\section{REFERENCES}

Aassalu, Heino 1999. Murrangud eesti rahvatantsus ja harrastusrahvatantsus. [Upheavals in Estonian Folk Dance and Hobby Folk Dance.] Tallinn: Rahvakultuuri Keskus.

Argyle, Michael 1999. Causes and Correlates of Happiness. In: Daniel Kahneman \& Edward Diener \& Norbert Schwarz (eds.) Well-Being: The Foundations of Hedonic Psychology. New York: Russell Sage Foundation, pp. 353-373.

Arraste, Angela 2009. Enne suuri pidusid. [Prior to Large Festivals.] In: Ilma Adamson \& Anneli Ammas \& Lille-Astra Arraste \& Kristin Kuutma \& Juris Žigurs \& Kadri Valner (eds.) 75 aastat eesti tantsupidusid. Tallinn: Varrak, pp. 13-18.

Arraste, Angela \& Zajedova, Iivi \& Rüütel, Eha 2011. Rahvatantsuharrastusega seotud kultuuri- ja suurpeod väljaspool Eestit. [Folk Dance Hobby Related Culture and Large Festivals Outside of Estonia.] Mäetagused, Vol. 49, pp. 49-64. Available at http://www.folklore.ee/tagused/nr49/valispeod.pdf, last accessed on July 7, 2013.

Cohen, Sheldon 1991. Social Supports and Physical Health: Symptoms, Health Behaviors, and Infectious Disease. In: E. Mark Cummings \& Anita L. Greene \& Katherine H. Karraker (eds.) Life Span Developmental Psychology: Perspectives on Stress and Coping. Hillsdale, NJ: L. Ehrlbaum Associates, pp. 213-234.

Deci, Edward L. \& Ryan, Richard M. 2000. The "What" and "Why" of Goal Pursuits: Human Needs and the Self-Determination of Behavior. Psychological Inquiry, Vol. 11, No. 4, pp. 227-268, doi:10.1207/S15327965PLI1104_01.

Deci, Edward L. \& Ryan, Richard M. 2008. Facilitating Optimal Motivation and Psychological Well-Being across Life's Domains. Canadian Psychology, Vol. 49, No. 1, pp. 14-23, doi: 10.1037/0708-5591.49.1.14.

Eesti tantsu iseloom 2009 = Eesti tantsu iseloom ja muusika. [Nature and Music of Estonian Dance.] Available at http://www.folk.ee/kultuurilaegas/et/aa_index/rt_ rahvatants_ja_tantsupidu/Eesti-tantsu-iseloom-ja-muusika/Pealkirjata-lehekulg, last accessed on July 7, 2013.

Forrester, Michael (ed.) 2010. Doing Qualitative Research in Psychology: A Practical Guide. London: Sage.

Glaser, Barney G. \& Strauss, Anselm L. 1967. The Discovery of Grounded Theory: Strategies for Qualitative Research. Chicago: Aldine.

Jõe, Heino 1985. Kotkajärve Metsaülikool. [The Forest University at Kotkajärve.] In: Valdu Lillakas (ed.) Eestlased Kanadas II. Totonto: Kanada Eestlaste Ajaloo Komisjon. Available at http://www.eesti.ca/mu/ajalugu, last accessed on June 26, 2013. 
Kangro, Bernard 1976. Eesti Rootsis. Ülevaade sõnas ja pildis. [Estonia in Sweden.] Lund: Eesti Kirjanike Kooperatiiv.

Kapper, Sille 2009. Kuidas uurida eesti rahvatantsu tänapäeval? Teooriatest, meetoditest ja nende rakendamisest Eestis. [How to Conduct Research on Estonian Folk Dance Today? About Theories, Methods and Their Implementation in Estonia.] Mäetagused, Vol. 41, pp. 75-98. Available at http://www.folklore.ee/tagused/nr41/ kapper.pdf, last accessed on July 7, 2013.

Kõiva, Mare 2010. Eestlased ja eesti keel Austraalias. [Estonians and the Estonian Language in Australia.] In: Kristiina Praakli \& Jüri Viikberg (eds.) Eestlased ja eesti keel välismaal. Tallinn: Eesti Keele Sihtasutus, pp. 265-283. Available at http://www.eki.ee/books/eekv/EEKV.pdf, last accessed on June 26, 2013.

Kokla, Juhan \& Raukas, Helga \& Sepp, Reino \& Üürike, Madis (eds.) 1956. Eesti Kroonika 1957: esimene aastakäik. [Estonian Chronicle 1957: The First Year of Issue.] Stokholm: EMP.

Kool, Ferdinand 1999. DP Kroonika: Eesti pagulased Saksamaal 1944-1951. [Estonian Refugees in Germany 1944-1951.] Lakewood, NJ: Eesti Arhiiv Ühendriikides.

McGill, Judith 1996. Developing Leisure Identities. Brampton, Ontario: Brampton Caledon Community Living.

Põldmäe, Rudolf \& Tampere, Herbert 1938. Valimik eesti rahvatantse. [Selection of Estonian Folk Dances.] Eesti Rahvaluule Arhiivi Toimetused 8. Tartu: Eesti Rahvaluule Arhiiv.

Purje, Eerik \& Varangu, Saima 1984. Esto '84: IV Ülemaailmsed Eesti Päevad, 8.-15. juuli 1984, Toronto, Ontario, Kanada. [4th Estonian World Festival, July 8-15, 1984, Toronto, Ontario, Canada.] Toronto: Esto '84.

Raudkats, Anna 1926. Eesti rahvatantsud. [Estonian Folk Dances.] Tartu: Postimees.

Revill, George 2004. Performing French Folk Music: Dance, Authenticity and Nonrepresentational Theory. Cultural Geographies, Vol. 11, No. 2, pp. 199-209, http://dx.doi.org/10.1191/14744744004eu302xx.

Russell, Ruth V. 2009. Pastimes: The Context of Contemporary Leisure. 4th ed. Champaign, IL: Sagamore Publishing.

Ryan, Richard M. \& Deci, Edward L. 2000. Self-Determination Theory and the Facilitation of Intrinsic Motivation, Social Development, and Well-Being. American Psychologist, Vol. 55, No. 1, pp. 68-78, http://dx.doi.org/10.1037//0003-066X.55.1.68.

Shoupe, Catherine A. 2001. Scottish Social Dancing and the Formation of Community. Western Folklore, Vol. 60, No. 2-3, pp. 125-147, http://dx.doi.org/10.2307/1500373.

Snape, Robert 2009. Continuity, Change and Performativity in Leisure: English Folk Dance and Modernity 1900-1939. Leisure Studies, Vol. 28, No. 3, pp. 297-311, http://dx.doi.org/10.1080/02614360903046235.

Strauss, Anselm L. \& Corbin, Juliet M. 1990. Basics of Qualitative Research: Grounded Theory Procedures and Techniques. Newbury Park, CA: Sage Publications.

Toomi, Ullo 1953. Eesti rahvatantsud. [Estonian Folk Dances.] Tallinn: Eesti Riiklik Kirjastus.

Vissel, Anu 2004. Rahvatantsu asendist eestlaste kultuuripildis ja harrastustes. [Folk Dance in Estonians' Culture and Hobby Activities.] In: Ingrid Rüütel (ed.) Pärimusmuusika muutuvas ühiskonnas II. Töid etnomusikoloogia alalt 2. Tartu: Eesti Kirjandusmuuseumi etnomusikoloogia osakond, pp. 109-131. 
Zajedova, Iivi \& Rüütel, Eha 2009. National Cultural Hobby Activities of Estonians in Exile and Their Role as a Means of Preserving Estonianism. Ethnologia Actualis Slovaca (The Journal of Ethnographical Research), Vol. 9, pp. 97-109.

Zajedova, Iivi \& Rüütel, Eha 2012. Comparative Analysis of the Role of Estonians Folk Dance Activity. Faravid. Pohjois-Suomen Historiallisen Yhdistyksen Vuosikirja, Vol. 32, pp. 193-210.

Zajedova, Iivi \& Rüütel, Eha \& Arraste, Angela \& Järvela, Kalev 2009. Rahvatantsuharrastus pagulaseestlaste hulgas ning selle roll eestluse säilimisel. [Folk Dancing among Estonian Expatriates and its Role in the Preservation of Estonian Identity.] Mäetagused, Vol. 41, pp. 99-123. Available at http://www. folklore.ee/tagused/nr41/pagulus.pdf, last accessed on June 26, 2013. 


\title{
TRADITIONAL CHILDREN'S GAMES OF BIHAR
}

\author{
Sarita Sahay
}

\begin{abstract}
This article aims at exploring how children, particularly in rural areas of Bihar, an economically poor but culturally rich state of India, enjoy their leisure with limited resources available to them. Broken bangles, tamarind seeds, old clothes and even hard covers of old notebooks become sports equipment and a source of enjoyment for them, especially for those who cannot afford buying expensive goods.
\end{abstract}

Keywords: Bihar, India, traditional games, limited resources, oral tradition

\section{INTRODUCTION}

A game is a situation that involves two or more players, and in which each player faces a choice between, at least, two behavioural options and strives to achieve the greatest payoff possible (Michener 2000). It is a natural consequence of what it means to be human. Through games, we express ourselves (Hyland 1990; Mead 1962).

All games have certain criteria such as a goal, chance, competition, common experiences, equality, freedom and no impact on reality, and depending on the game, people are engaged in some activities, such as thinking, planning, decision-making, concentrating, timing their minds and gaining knowledge. In addition, in all the games, some or all of the players have fully or partially opposing interests, which causes the behaviour of players to be proactive and strategic. Thus, all the games become sources of moderate exercise, either physical or mental or even both, and the exercise is essential for all of us. The benefits of games are twofold. Firstly, the health-improving impact, which results from moderate exercise, and secondly, the relaxation for a few minutes or a few hours enables us to forget the outside world of today completely (Tunis 1944). 


\section{BIHAR: LAND AND PEOPLE}

Bihar, one of the states of India, is situated in the north-eastern part of the country. Its capital is Patna. To the north of Bihar is the kingdom of Nepal. Bihar is surrounded by three Indian states: Uttar Pradesh to the west, Jharkhand to the south and West Bengal to the east. The people of Bihar are called the Bihari.

The name Bihar derives from the Sanskrit word vihara, which means 'abode'. The Buddhist Viharas, the abodes of the Buddhist monks, dotted the area in the ancient and medieval period.

Hindi, which is spoken by more than $90 \%$ of the urban population, is the official language of Bihar. In addition, Hindi, Bhojpuri, Magahi, and Maithili are also spoken mainly in the rural areas.

The state is blessed with three well-defined seasons: the winter season from November to February, the hot period of summer from March to mid-June, and the rainy season from mid-June to October. The temperatures in December and January fall at times close to the freezing point, while those in May rise above forty degrees. According to the Indian Census Report (2011), the population of Bihar is 103,804,637 and the density of the population is 1100 per sq $\mathrm{km}$. The literacy rate in Bihar is $63.82 \%$ only.

More than $80 \%$ of the inhabitants of Bihar are the Hindus. The Muslims constitute a larger minority group than the Sikhs, Jains and Christians, who are also part of the population of the state.

The economy of Bihar is mainly based on agriculture as well as trading activities. The chief crops are rice, barley, maize, paddy, sugar cane and wheat. The state is also a large producer of freshwater fish. Almost $80 \%$ of the total population of Bihar live in villages. The state has very low literacy rate. According to the World Bank report (Report 2010) Bihar is one of the poorest states of India; yet, a new reform implemented by the government of Bihar and backed by the World Bank funding and technical support is helping to reduce poverty.

Sites of religious and cultural interest are found throughout the state of Bihar. The state attracts visitors due to its importance in Buddhist religion. Nalanda is famous for being the seat of the ancient and celebrated Nalanda Buddhist monastic university. Pawapuri is the place where Lord Mahavira, the founder of the modern Jain religion, supposedly attained nirvana (heavenly abode). Likewise, Gaya is an important place of pilgrimage for the Hindus. Buddha Gaya (Bodh Gaya), where Lord Buddha attained enlightenment, is considered to be the holiest place in the world by the Buddhists. Rajgir is another holy place for both the Hindus and the Buddhists. Takhat Shri Harmandir Sahib, the birthplace of the last (tenth) Guru of the Sikhs, Guru Gobind Singh, in Patna city, is a holy place for the Sikhs. Bihar is an important pilgrimage destination for Buddhists from India and across the globe. 
The Chhath is a major festival of Bihar and is celebrated a week after the Deepawali (the festival of lights). The Chhath is dedicated to the worshipping of the God of Sun. People in large numbers hold Chhath Puja at river banks and the festival is celebrated across Bihar. During the festival, married women observe a fast for 36 hours and devotees offer wheat, milk, sugarcane, bananas and coconuts to the Sun. The ritual bathing is performed twice: in the evening and during the dawn, usually in the knee-deep water of a river (Bezbaruah 2003: 11).

Teej and Chitragupta Puja are some other local festivals. Teej is an old festival, dedicated to Goddess Parvati, and is celebrated for the well-being of the spouse and children, and the purification of one's own body and soul. The festival is a three-day-long celebration that combines the features of feasts and fasting (Bezbaruah 2003: 11). The Shravani Mela of Sultanganj, organised in July and August, is of great importance for the people of Bihar. The Sonepur cattle fair, held approximately fifteen days after the Deepawali, is the largest cattle fair in Asia. In addition to these, all the major festivals of India are also celebrated in Bihar, such as the Makar Sankrantri, the Sarswatipuja (to worship the goddess of knowledge), the Holi, the Eid-ul-Fitr, the Eid-ul-zoha, the Muharram, the Mahashivratri, the Buddha Purnima, the Rakhi, the Mahavir Jayanti, the Durga Puja, the Lakshmi Puja, and also Christmas.

\section{CHILDREN OF BIHAR AND THEIR GAMES}

Playing games is a common characteristic of children all over the world. However, Riess (1989) finds that the rising income level due to the development of the industrial radial city and diverse social values have resulted in different leisure options for different social classes. Due to the growing demands for higher academic achievements and concerns about safety issues, children's time available for unrestricted free play has decreased considerably (McMahon \& Sutton-Smith 1999). Parents in Bihar, just like any other parents, no matter how uneducated they might be, also realise that games and physical exercises are essential for the growth of their children. They try to organise activities pertaining to games within very limited resources. Inability to provide expensive gadgets makes them fall back to traditional games. Parents insist on their children's playing outside home. Though it is not institutionalised, it is customary that evening hours (5 p.m. to 7 p.m.) remain game-hours for each child. In hot or cold climate, in open space or crowded parks, in cities or villages, in streets or playgrounds children jump, run, hide, chase each other, and sing and laugh wholeheartedly. 
In schools ${ }^{1}$, as a rule, the last period of the day remains fixed for games. Games played in schools offer to the children an opportunity for socialising with the members of various teams, be it from the same class or the same school or other schools. But not all the students are so fortunate as to get a chance to join the school team so that they could take part in interschool tournaments.

In Bihar club-culture is negligible. It is difficult for the children to join any club and play cricket, tennis or badminton for that club. Besides, poor kids cannot afford to buy expensive tennis rackets, nor are tennis courts available to them. Among the modern games only cricket is popular.

Although children play both indoor and outdoor games, the evening hours are generally meant for outdoor games. However, they play simple but expressive games through which they develop a sense of victory and defeat as well as amplify the traits of leadership. There are numerous traditional games played not only in Bihar but also all over India. The selection of the game is based on the availability and number of other children, sports equipment and the age-group of the children. They save their pocket money for buying sports items; however, the majority of them cannot afford anything expensive, so most of the items they play with are not very costly. Girls generally play with the items available at home. They prefer to spend their pocket money on coloured ribbons, nail polish, ear tops, etc. Again, there are many games which do not require any money.

Some games require a group of boys and girls whereas others are played either by girls or boys only. Irrespective of the location chosen for playing - school or home or elsewhere - games are designed to provide fun and entertainment. In addition, games help to inculcate physical and mental control among the participants.

Below the author gives an overview of some popular games played by boys and girls in Bihar, which were selected in view of their popularity. There is hardly any printed or published literature describing these games. However, descriptions of some games such as kabaddi and pachisi are available on the Internet.

Information about these games was gathered from field visits and personal childhood experience. The described games are chosen from those which are most popular among children. It should be noted that some of these games are also played in other parts of India with minor alterations in the format and a few of these games are played by adults as well. 


\section{TEER-DHANUSH (BOW AND ARROW)}

One of the oldest games played is the teer-dhanush (arrow-bow), with the bow made of split bamboo and string and arrows from thin bamboo sticks. A target is chosen on a wall or tree and boys shoot arrows to hit it. During one of the biggest traditional festivals (ten days long), the Dussehra vendors sell colourful bows and arrows on the roadside or at fairs organised in villages and towns. Generally boys under the age of twelve play this game. The game regained popularity after the telecast of some TV series, such as the Ramayana and the Mahabharata, based on great Indian epics and mythology in the 80s and 90s of the last century.

\section{EKHAT-DUKHAT (HOPSCOTCH)}

It is played with a thippi: a broken piece of an earthen pot, about an inch-anda-half in diameter, or a round flat stone. A rectangle about three yards long and two yards wide is drawn. This rectangle is divided into six squares each about a foot wide. The fourth and the sixth squares are each subdivided into two and these are crossed diagonally from side to side.

The first player stands before the starting line and tosses her thippi into the first square. Then she skips the first square, hopping to square number two and continues hopping up to square six. Then she turns around and hops back. She stops in square number two, picks up the thippi, hops over square one and comes out. She continues playing by tossing the thippi in square number two, three, four and so on in subsequent steps. All the hopping is done on one foot, except for those squares that are divided into two and drawn side by side. She puts both her feet down into the two squares with one foot in each of them. The player must hop over or skip the square where the thippi has been placed.

A player is declared OUT if the thippi fails to land in the appropriate (progressively higher) square, or the player steps on a line, or loses her balance while bending to pick up the thippi, or puts her other hand or foot down or steps into the square into which the thippi has been tossed.

This game is popular among girls. They play this game during recess at school. Two, three or more girls from the neighbourhood get together to play this game at a place near their homes in the evenings. Sometimes boys also join them if they have no other game to play. 


\section{GOLI OR KANCHEY (MARBLES OR GLASS BALLS)}

This game is played with glass balls or marbles. One can buy beautiful coloured marbles from shops. The game is so intoxicating that boys often deserve a thrashing from their parents for spending too much of their time playing it.

Each player has to have a goli. On even ground, a little hole is dug with the heel of the foot. The players position themselves about two yards away from the hole. Then they kneel down and try to send the marble into the hole. The marble is held tightly with the forefinger of the left hand. The finger is stretched back like a bow-string by the pressure of the forefinger and thumb of the right hand. When the finger is released, the goli goes forward, often overshooting the hole. One has to strike out of the way the golis thrown by the other boys or, with a gentle blow from one's goli, push the other golis, so that they drift into the hole. 'Ah! Goli mari!' is the exited cry as one's goli succeeds in striking another boy's goli aside. The latter then waits for his turn to strike his peer's goli. Whoever is the first to get all the golis (balls) into the hole, is the winner of all the golis. This game takes several hours. Children in one street or lane play this game under the shadow of big tree, usually near their homes. At the end of the game, there is always the danger of a big bully snatching all the golis of the smaller boys, unless the bully has won the game.

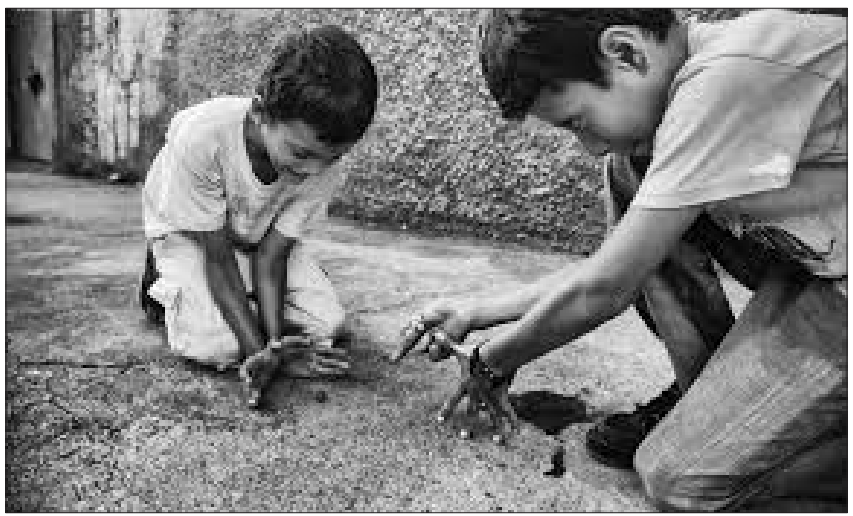

Figure 1. Children playing kanchey. (Source: http://t2.gstatic. com / images? q=tbn:ANd9GcRKBYrZ_QMdTi866C17eYJGl7qRxbthMlO_qHcxgctFBOI6zBF) 


\section{LOOKA-CHHIPI (HIDE AND SEEK)}

Children start playing this game at a very early age. Two-to-three-year-old children play this game with their mothers, grandmothers or elder sisters. A child is asked to close their eyes with the palms of their hands and the mother hides somewhere. Then she calls the child to come and find her. The child runs here and there and everywhere in search of the mother. If the child finds the mother within a limited time, they laugh; if not, they burst into tears. When the mothers sees the child crying, she comes out, or sometimes when she senses restlessness in the child she partly reveals herself so that it becomes easy for the child to find her. This game becomes funny when the mother closes her eyes and the child is asked to hide. The innocent child declares loudly, "Grandma! Don't tell Mom that I am hiding behind the cot". The grandmother too, tells jokingly, "No! I will not tell her that you are hiding behind the cot". The mother, knowing exactly where the child is, runs here and there, to the veranda and into all the rooms and the child enjoys watching her run. Other members of the family also enjoy watching this game.

When a child grows up, they find that this game requires more skills when played with a group of their peers. They can be so clever at hiding themselves that the finder roams about, trying to locate the others, following the sounds they make but does not succeed. It is because by the time the finder reaches the place where the shout appeared to have come from, the one hiding has already moved to another place. The child who covers the eyes of the finder keeps the palms tightly on the finder's eyes, until everyone has gone hiding. Usually the youngest child is chosen to find the older ones.

Sometimes this game is used as a trick by the older children when they do not want to play with the younger ones. They ask the younger child to close their eyes while facing a wall or a tree and count from one to a hundred; by the time the counting is finished they have run far away to play another game. The youngest one is thus abandoned to shed tears.

\section{LATTOO (TOP)}

When a boy grows to be ten or older, he learns the skill of the spinning lattoo. Boys save their pocket money to buy a beautiful pear-shaped top made of wood, with a pin at the bottom. This is set into motion by aid of a string with a hard jerk and released onto a hard surface to spin. The boy whose lattoo moves the longest wins the game and gets a chance to spin the lattoo of the loser. 


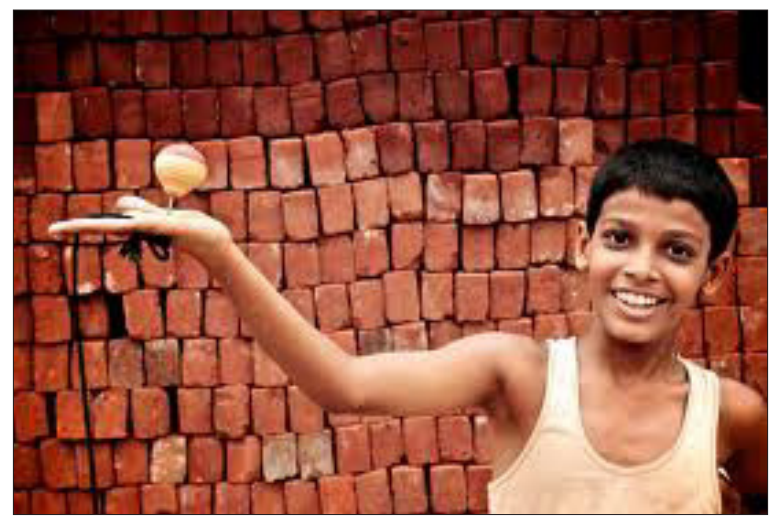

Figure 2. A boy playing lattoo. (Source: http://t2.gstatic. com / images? q=tbn:ANd9GcRPmmRxDfq7EJ8AtXba7Fucs OhA1SQrOL8qgkWQBZPxCqeWMjHlqg)

Small kids with no pocket money to buy a lattoo take a glass-shaped wooden reel with a hole in the centre and fix a small pencil into the hole. Thus, a homemade lattoo is ready for playing. Girls do not play this game.

\section{JHOOLA (SWING)}

In the month of Sawan (August), girls put up swings on the trees near their homes. One of them sits on the swing and another pushes it. The girl on the swing tries to get it higher and higher, singing a song all the while. Sometimes one of the older girls takes a young one in her lap while she swings, holding the frightened baby fast to her chest. The one who swings the highest is the winner. Sometimes boys also join them.

\section{CHHUA-CHHUAI (TOUCH ME TOUCH ME NOT)}

Two or more boys or girls usually play this game, one chasing the other. The child who leads touches a tree or a wall or any other chosen object. Then they run fast to the next chosen object so that they are not caught by the others. In this way they run from one object to another until they are caught while not in contact with any of the objects. When the chaser catches the chased, they switch roles. 


\section{$K A B A D D I^{2}$}

To play kabaddi, one needs stamina, the capacity to hold breath, swiftness and mastery of battle tactics. A line is drawn on sand or on soft earth. Two opposing teams, each comprising five to ten children, stand on either side of the line. A member of one team crosses the line into the opposing camp, chanting the word kabaddi, while holding the breath. If they are able to touch one or more members of the opposite team while still uttering the word kabaddi, and return to their own side after that, those touched are 'dead' and the raider's side has all the members 'alive'.

But it may as well happen that the raider is physically caught (grabbed) on the opposite side by those whom he touched or by all other members of the opposite team collectively. Then the raider in an attempt to return has to at least touch the dividing line without losing breath while chanting the word kabaddi. If they succeed in returning or touching the dividing line, all those who were trying to catch them or touched them are declared 'dead'; otherwise, the raider who is captured is said to be dead. Next, a member from the opposite team comes to raid the opposing team. A team has to 'kill' all the members of the opposing team to win the game. Both boys and girls play this game with their neighbourhood friends of the same sex; yet, boys and girls avoid playing this game together.

\section{PATANG BAZI (KITE FLYING)}

Patang bazi is children's most beloved game and the onlookers also utterly enjoy it. It looks great when the sky is covered with colourful kites and a cool breeze takes them higher and higher. Another kite flyer, who is trying to bring the kite down, entangles his kite with yours, and an exciting kite fight starts. It is exciting not only up in the sky but also on the ground, when kite looters run along with the kite without caring what they are doing or where they are going.

Kite flying requires much pocket money as you have to buy many kites, reels of thread and other accessories. Kites come in different sizes and shapes. The common one available at markets is generally square-shaped, whereas some are rectangular and some are made of two ovals joined together. There are also kites with tails. Fine paper is used for making kites. It is strung on a frame of thin bamboo, one stick positioned lengthwise, the other like a bow across it. The kite paper is fastened to the frame with glue. About three inches from the top and four inches from the bottom of the longitudinal stick, fine thread treated with powder glass is fastened, forming a triangle. This is attached to hundreds 


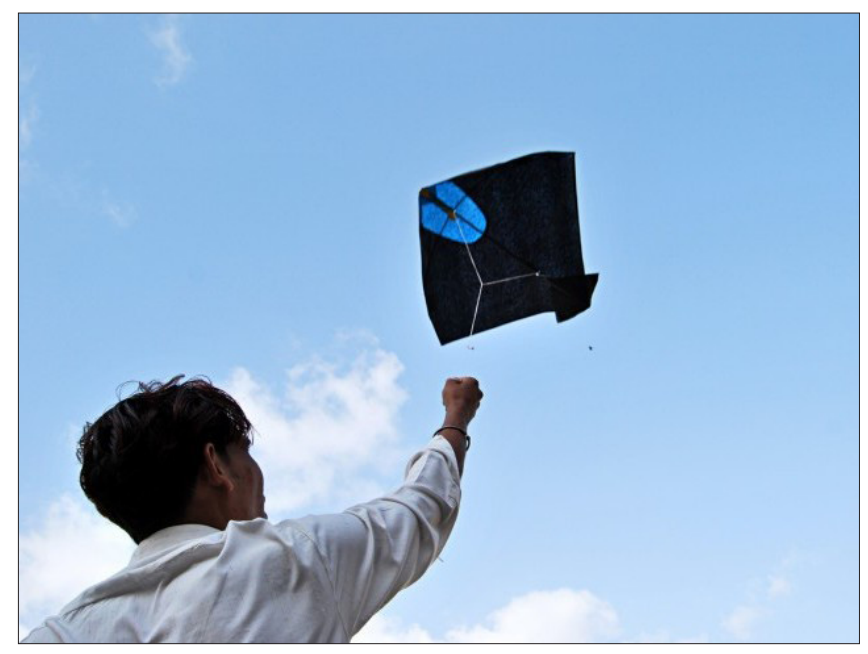

Figure 3. Kite-flying. (Source: http: // www.itdunya.com/ attachments / 324850d1323087583-292929-dsc_-1321462698-773640x480.jpg)

of yards of thread, also treated with powder glass and wound around a spool. The thread on the spool revolves in the hands of the learner as the expert flies the kite. The fight is encouraged by the onlookers by shouting, 'Woh! Katta!' (Look, it's cut!). The person whose kite is cut is the loser and the loser tries to get back his kite from where it fell down.

Every year kites are flown with great enthusiasm on January 14 (Makarsankranti festival day). The sky is filled with colourful kites and it is a scene worth watching. The atmosphere is charged. Girls do not fly kites but enjoy watching it. Sometimes they would hold the spool while their brothers fly the kite.

\section{RUMAL CHOR (HANKY THIEF)}

Rumal chor is an outdoor game but it can also be played inside if one has enough room to run around. This game can be played with as many members as present. The minimum number of participants is six, out of whom one is the chor (thief). The members playing the game sit in a circle with their eyes closed and sing: "Ghoda badam khai, pichhe dekhe jo uski shamat aai" (Horse eats almonds, trouble awaits the one who looks back). 
The players sing this song three or four times and within this period the chor leaves his hanky (or a small piece of cloth) behind one of the sitting players. When the singing ends, everybody opens their eyes and looks for the rumal behind them. The one who finds the rumal runs after the chor to catch him. The chor runs around in circle and tries to save himself from being caught and take the vacant seat of the person chasing him or her (with the rumal); if they are caught by the person with the rumal before grabbing the vacant seat, they switch roles. The game turns more interesting when it is played at a fast pace and involves all the participants, so that every time the rumal is dropped behind a new player. The more players, the merrier the game: this is the rule of this game. The best part of the game is when you sing while expecting the chor to drop the rumal behind you. Girls and boys play this game together.

\section{DENGA PANI (LAND AND WATER)}

This is also an outdoor game. It can be played in a park or where part of the ground is higher. The terms used in the game are denga (land: area higher than the ground level), pani (water: the ground area or the lower surface), and magar (crocodile: the person who has to catch the other players). The game requires four or more participants, out of whom one is the magar. All the participants stay on the denga and the magar remains in the pani. Whereas the members of 'land' try to roam around in 'water', the magar would not let the other players cross or stand in his or her area (water). If any of them is caught by the magar in 'water', they will be out of 'land' and it is their turn to act as the magar. The game is simple and enjoyable if the participants do not stick to their places for long and keep moving frequently from 'land' to 'water' and vice versa. You can help your mates by diverting the magar's attention by entering their area and teasing them with a song, "Hum tumhare pani me, pakado" (I am in your area, catch me if you can). It is enjoyable in case more than one person teases the magar and the latter runs in different directions, trying to catch the running mates. Children enjoy this game and play it for hours till they get tired. Girls and boys play this game together.

\section{GULLI-DANDA}

This game is very popular among children in rural areas. Gulli is a three-four inches long piece of wood cylindrical in shape. Its diameter is approximately one inch. It is sharpened from both ends like a lead pencil. Danda is a wooden 
stick. The length of the danda is approximately twenty-four inches. A small gaddha (pit) shaped like a banana is dug into the ground. The length of this pit is about four inches. Two boys can play this game. The first player places the gulli across the pit and puts his danda into the pit under the gulli and holds the danda at an angle of about 45 degrees from the ground. He then pushes the gulli off. The second player tries to catch the gulli; if he succeeds in catching it, the first player is out and the second player gets a chance to push the gulli in a similar way. But if the second player fails to catch the gulli, the first player places the danda on the pit and the second player throws the gulli on to the danda from the point where the gulli had landed. Even if he succeeds in hitting the danda, the first player is out and it will be the second player's turn to play. If the throw misses the target, the first player places the gulli on the ground but not on the pit and bounces it slightly by hitting one of its ends with his danda; while the gulli is still in the air, he tries to hit it hard with his danda as far as he can, away from the pit. The second player tries to catch it again. Even if the first player misses the chance to hit the gulli while in the air, the first player is out. The distance between the pit and the place where the gulli falls is measured by the length of the gulli and the player gets points correspondingly.

It is a dangerous game. Sometimes the gulli hits the players' eyes. Girls avoid playing this game. Parents do not encourage their children to play this game, but the latter nevertheless do it.

\section{PITTO}

Children divide themselves into two teams. Both the teams stand at a distance of several yards from each other with seven or nine or eleven stones placed midway on a spot and piled up in the shape of a pyramid. A member of the first team takes a ball and tries to strike the stones to topple the pile. The player has to be given three chances to hit the pile. If the member of the first team fails to do so, the second team gets the ball to try. If the first team member manages to hit the pile but any member of the second team catches the ball before it bounces back to the ground, the ball will again be passed on to the second team for continuing the game. If the members of the second team fail to catch the ball, their aim is to stop the members of the first team from assembling the stones to form a 'pyramid' again. To prevent the first team members from doing so, the members of the second team try to hit the members of the other team with the ball. The members of the first team try to avoid contact with the 
Figure 4. A boy playing pitto. (Source: http: / / t1.gstatic.com / images? $q=t b n: A N d 9 G c S u y$ RUtkk9eCAWBdy4LxSKIMmCVqbGRzXwVvdJP8M8lXpmIqU-IA)

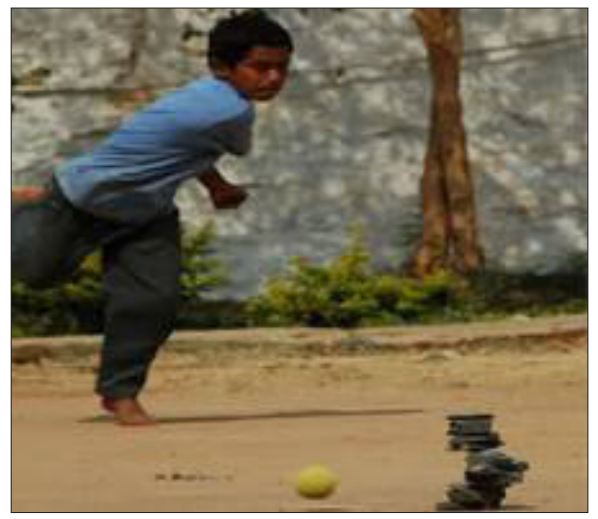

ball. If the first team manages to re-pile the stones without any of its members being hit by the ball, they again retrieve the ball to strike the stones, or else the ball is given to the second team to take their chance. This game inculcates team spirit among the players. It is more popular among girls; however, boys and girls play this game together as well.

\section{KATTAM-KUTTAI}

This game is very popular among girls although boys also play it. Only two players are needed for playing this game. This game is played with eighteen $(9+9)$ coins in two different colours. You can also use pieces of broken bangles in two different colours or two varieties of seeds or beads. On a plain piece of paper or on the ground two triangles are drawn in hourglass shape. These two triangles are divided into four parts by drawing a straight vertical line. In each triangle two lines parallel to the base are drawn. Thus in each triangle nine meeting-points are formed, in which two lines intersect. At these intersections beads are placed, with the joining point of the two triangles remaining vacant. Two girls select their own triangles and sit facing each other. The first player moves her bead in the vacant place and the second player captures this bead by jumping over it and going to the next vacant place. In this fashion the game moves on. The one who is the first to capture all the beads of the other player is declared the winner. Girls spend hours playing this game, starting one round after the other. 


\section{CHAI-CHUDI}

Chai-chudi is a popular girls' game requiring two to four participants. This game is played with broken bangles and tamarind seeds. A square is drawn on the floor. This square is further divided into twenty small squares. The middle square of each row is declared 'castle square'. The central square is called 'home', whereas each central square of the outer rows is declared a starting point. Two tamarind seeds are broken into two halves with a hammer or stone. These four pieces of tamarind seeds are used as a dice. They are thrown onto the floor. The number of seeds with white part upwards indicates how many spaces a player may move. During the game, the players' pieces move along the squares. If a piece lands on a square other than 'castle square' occupied by any other player's piece, that piece is captured and must return to the starting point. The player who moves all her pieces home first is the winner. The one among the four players who fails to move all her pieces home is declared loser.

\section{PACHISI}

Pachisi a national game of India; it is a cross and circle board game that originates from the ancient past, and is also popular in Bihar. Pachisi is a game for two or four players, sometimes in two teams. Each player has four beehive-, round- or square-shaped pieces. The pieces of one player are distinguishable from those of others by their colour: red, black, green, and yellow are used. Six cowrie shells are used as a dice. They are dropped by each player in turn and the number of the cowries that fall with their openings upwards indicate how many spaces the player can move the pieces on the playing board, which is shaped like a cross, with a large square in the centre regarded as 'home'. The four arms of the board are divided into three columns of eight squares each. During the game, the players' pieces move along these columns of squares. Pachisi or 'that after twenty-five' is indicative of the highest score (25) that can be thrown by a player with cowrie shells for moving the pieces on the board. The one who is able to bring all the pieces home after moving through all the four arms of the cross is the winner.

This game is popular among young people as well as adults and has been played all over the subcontinent for thousands of years. During the Deepawali festival this game is played by gamblers; the winner believes that he has received the blessings of Goddess Lakshmi in the form of cash.

An interesting occasion when Pachisi is played is during the marriage ceremony when the newly married couple is made to play it. The outcome of the 


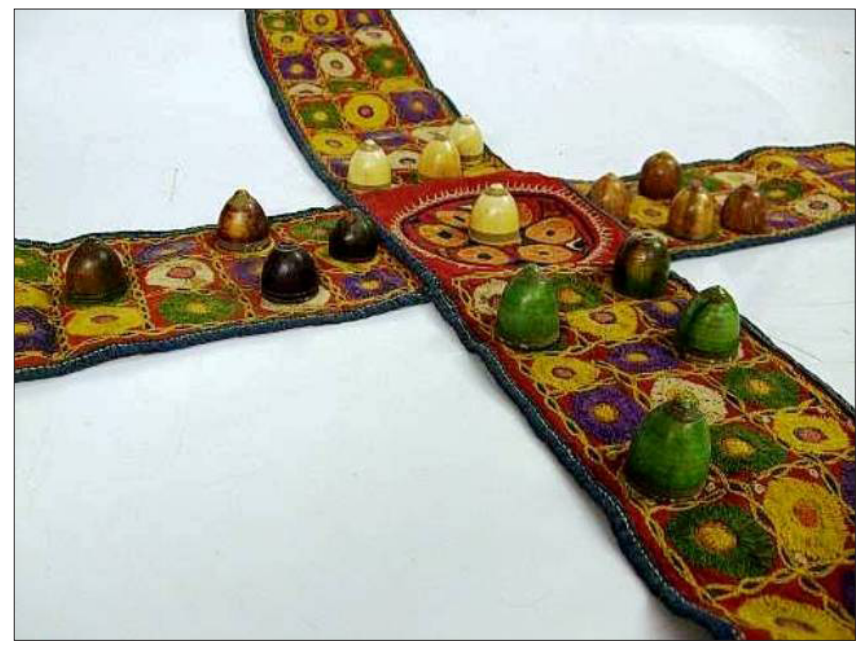

Figure 5. Pachisi board with pieces. (Source: http:// www.crumiller.com / chess / chess_photos / miscellanea / PachisiIvoryPiecesWithBoard.jpg)

game is supposed to indicate who will play a dominant role in the married life. The groom makes every attempt to win in order to be the ruler of his house. The game of Pachisi played during a marriage ceremony is sometimes a simplified form of the otherwise elaborate game.

This game is said to be a predecessor of the 19th-century game in Europe, called Ludo, but there are many other westernised commercial versions of it (see http://en.wikipedia.org/wiki/Pachisi).

\section{GUDDA-GUDDI KI SHADI (MARRIAGE OF DOLLS)}

This is again one of girls' popular games. Girls request their mothers or grandmothers to make dolls. Pieces of cloth are used for making them. Toy kitchen goods made of plastic or tin are bought at the market. Toys made up of clay, cloth and wood are sold during festive periods. Radha-Krishna, elephants, horses, birds, etc., are favourites with children. Girls use these toys to decorate their doll houses.

Sometimes they arrange marriages for their dolls. At first, they divide themselves into two groups. One group acts as the boy's party and the other group as the girl's party. They sing and dance and perform all the rituals of a real 


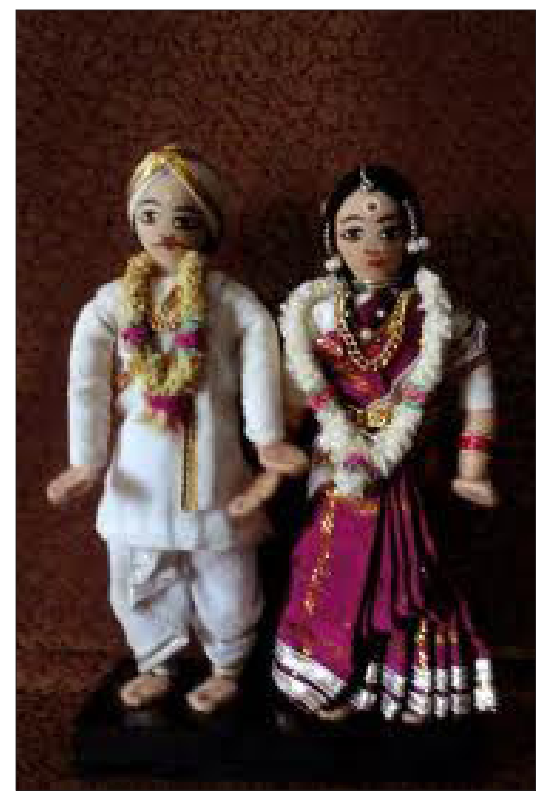

Figure 6. Marriage of dolls. (Source: http: / / to.gstatic.com / images? $q=t b n$ : ANd9GcQIvozFHxO5IoIps J $5 \mathrm{VHFaO}$ silMfyjEinJkWQrBbLKGMkIqwyN1w)

marriage. Sometimes boys also join the group when they realise that girls are going to distribute bhunja (roasted grains) and gur (jaggery) after the wedding ceremony. They spend hours organising and performing these ceremonies.

\section{CONCLUSION}

The article introduces seventeen traditional games of Bihar. According to the classification of games provided by folklorist Anu Vissel, games can be divided into: (1) running games, (2) jumping games, (3) skill-demonstrating games, (4) strength-demonstrating games, and (5) throwing games (Vissel 1997). So, fourteen out of these seventeen games can be grouped into these five broad categories: (1) running games: looka-chhippi, chhua-chhuai, rumal-chor, denga-pani and pitto; (2) jumping games: ekhat-dukhat; (3) skill-demonstrating games: goli, lattoo, patang-bazi, gulli-danda and kattam-kuttai; (4) strength-demonstrating games: jhoola and kabaddi; (5) throwing games: teer-dhanush. A sixth category of games appears necessary to be included here, which consists of games meant for entertainment only: gudda-guddi ki shadi, chai-chudi and pachisi.

In addition to these games, there are many other traditional games like gho-gho rani, atta-patta, and raja-mantri-chor-sipahi, which children play at different stages of their childhood. 
Games of more recent times, which have reached here through metropolitan cities (Carom, Ludo, Snakes and Ladders, Business, computer and video games), are also played in Bihar. However, these are played by the children of the urban areas or economically better off strata.

Playing games is a common characteristic of children. All over the world, children like to run, play, laugh and enjoy themselves. Games involving much movement and running satisfy younger and older children's need to move and so develop their skills. Moving together, paying attention to one another, and adapting themselves to one another are skills that are developed by playing different types of games (Lazar 2005). Children play a variety of indoor and outdoor games. These games have a rich cultural and heritage value. They are an important vehicle for passing on some ancestral knowledge to the posterity. According to Edgardo Civallero (2006), "a people's intangible heritage is composed by the non-material part of its culture: tales and narratives, games and songs, music and all the knowledge usually transmitted by oral or sound means, in traditional societies as well as in urban westernized ones". Parents know it well that playing games is necessary for the physical as well as mental growth of their children. They insist that their children go out in the evening and play. Poor children enjoy their leisure, using whatever things available to them. Girls use broken bangles, tamarind seeds and old clothes in their games and resort to their imagination. When they make beautiful dolls, making use of old clothes, and doll houses from mud and hard covers of their notebooks, adults are also attracted to them. Similarly, when they make mats and baskets using grass and flower petals, it becomes a decorative item not only for their doll houses but for their own homes as well. Thus, the games that girls play not only entertain them but also help them develop some necessary skills. The imaginary power as well as girls' skills are appreciated by other people and this way they develop a sense of achievement. Sometimes the elders of the family, such as the father, grandfather or uncle, help their children in making swings and kites and solving of puzzles. This way they spend some quality time with their children. This strengthens the family bonds and develops a sense of family.

Thus, we see that games become a source of moderate exercise, either physical or mental or even both, for children, and are essential for their health and development; on the other hand, they constitute a source that develops group and family sense necessary for their social well-being. Poverty does not deter the children of Bihar from playing games and enjoying their leisure. 


\section{NOTES}

1 About $94 \%$ of schools in Bihar are located in rural areas. $69 \%$ of primary schools have a pucca (permanent building), $4.68 \%$ - a partly permanent building, and $0.78 \%$ - a temporary building. 2800 elementary schools and 15 upper elementary schools are working without a building (in tents, etc.). Most of the elementary schools in Bihar have 3-4 rooms. In 1991, a new universal educational programme was launched (Kaushal \& Patra 2011).

${ }^{2}$ Kabbadi - an Indian sport played by two teams. The Kabaddi Federation of India was founded in 1950, and it compiled a standard set of rules. The Amateur Kabaddi Federation of India (AKFI) was founded in 1973 (http://en.wikipedia.org/wiki/Kabaddi\#India, last accessed on June 20, 2013).

\section{REFERENCES}

Bezbaruah, Madan Prasad 2003. Fairs and Festivals of India. New Delhi: Gyan Publishing House.

Census Report 2011. Census of India 2011. Government of India, Ministry of Home Affairs. http://censusindia.gov.in/2011-prov-results/prov_results_paper1_india. html, last accessed on June 25, 2013.

Civallero, Edgardo 2006. Traditional Games, Music and Oral Tradition: Intangible Tools in Multicultural Libraries. http://eprints.rclis.org/10100/1/tradgame\%5B1\%5D. pdf, last accessed on June 19, 2013.

Hyland, Drew A. 1990. Philosophy of Sport. New York: Paragon House.

Kaushal, Savita \& Patra, Sudhanshu S. 2011. Elementary Education in Bihar: Some Reflections from DISE Data. http://www.dise.in/Downloads/Use\%20of\%20Dise\%20 Data/Savita\%20Kaushal\%20\&\%20\%20Sudhanshu\%20S.\%20Patra.pdf, last accessed on June 19, 2013.

McMahon, Felicia R. \& Sutton-Smith, Brian 1999. The Past in the Present: Theoretical Directions for Children's Folklore. In: B. Sutton-Smith \& J. Mechling \& T.W. Johnson \& F.R. McMahon (eds.) Children's Folklore: A Source Book. Logan: Utah State University Press, pp. 293-308.

Lázár, Katalin 2005. Why Play and Sing? The Role of Folk Games and Folk Songs in Everyday Life. Traditiones, Vol. 34 (1), pp. 191-197, doi: 10.3986/Traditio2005340115.

Mead, Georg H. 1962. Mind, Self and Society: From the Standpoint of a Social Behaviorist. Chicago: The University of Chicago Press.

Michener, H. Andrew 2000. Game Theory and Strategic Interaction. In: E.F. Borgatta \& R.J.V. Montgomery (eds.) Encyclopedia of Sociology. USA: Macmillan Reference USA.

Report 2010. Bihar - India's Poorest State - Begins to turn Around. http://web.worldbank. org/WBSITE/EXTERNAL/TOPICS/EXTTRANSPORT/EXTRURALT/0,,conte ntMDK:22497836 menuPK:515376 pagePK:64020865 piPK:149114 theSite PK:515370,00.html, last accessed on June 19, 2013.

Riess, Steven A. 1989. City Games. Chicago: University of Illinois Press.

Tunis, John R. 1944. Sport for the Fun of it. New York: A.S. Barnes \& Company.

Vissel, Anu 1997. The Traditional and the Recent in Modern Schoolchildren's Games. Journal of the Baltic Institute of Folklore, Vol. 2, pp. 134-183. 


\title{
SCHOOL OLYMPICS IN ESTONIA: NEW CHANCE OF LIFE FOR TRADITIONAL SPORTS AND GAMES?
}

\author{
Kalle Voolaid
}

\begin{abstract}
This article focuses on an interesting trend in the development of the School Olympic Games in Estonia - the use of traditional sports and games in the School Olympics programme as a means for a fresh approach to sport and education, to make the games more colourful, create a school identity and unite different cultural layers. The School Olympics - a remarkable form of the Olympic education - is currently facing serious challenges in keeping the attention of the younger generation, restoring the active life-style and reshaping moral principles. Traditional sports present a good opportunity to make a difference here. With the help of concrete examples this article gives an overview of the variety of colourful ideas used in Estonian schools, starting with popular traditional sports and ending with some newborn disciplines.
\end{abstract}

Keywords: ancient sports, School Olympic Games in Estonia, Olympic education, Olympic Games, traditional sports, traditional games

\section{NEW CHALLENGES IN OLYMPIC EDUCATION}

French educator Pierre de Coubertin, the founder of the modern Olympic Games, had a vision that the Olympic Games were not only a sports competition but also an educational and cultural event. He therefore developed a list of central educational principles of his own kind, which were influenced by individual effort and the friendly spirit of fair play. On the basis of these principles the core philosophy of the international Olympic Movement evolved, which today is introduced to the world by the International Olympic Committee (IOC) and the International Olympic Academy (IOA), with the help of Olympic education.

In today's changing world, Olympic education unfortunately faces serious challenges, losing the attention of the younger generation. Roland Naul, Olympic education expert from the University of Duisburg-Essen, Germany, summarises these main dangers as follows. 
Loss of active lifestyle. Less and less time is spent on games and sports both in daily life and in schools - together with the ongoing decline in the allocations given to physical education.

Loss of moral principles. The main characteristics here are the rise of aggression, violence and cheating, drug abuse, cultural and religious discrimination, negative changes in behavioural patterns - both in schools and in public life (Naul 2008: 164-165).

Dealing with these problems is the main goal of Olympic education today, otherwise we will just lose the battle for the Olympic principles. According to Naul (ibid.), we must restore an active lifestyle and re-shape our moral principles because without the former it is impossible to achieve the aims of the Olympic ideals and without the application of moral principles it is impossible to live by the spirit of the Olympic ideals.

It is for these reasons that the IOC, the IOA and the national Olympic committees and academies all over the world are making great efforts to find new and exciting possibilities for furthering and promoting Olympic education.

\section{SCHOOL OLYMPICS IN ESTONIA}

A quest for new educational possibilities is also pursued in Estonia. Following the positive example of some other countries, the School Olympic Games started to be organised here and soon it became the main educational project of the Estonian Olympic Academy (EOA).

The goal of the School Olympic project was to introduce the Olympic Movement to young people and give them a possibility to experience the Olympic feeling. Largely, the ideas from the Silver Springs Elementary School in Alberta, Canada, were followed (Viru et al. 1999: 25-26). At Silver Springs a real Olympic Festival was organised in the school, the Olympic topic was used in different school disciplines and festive Olympic ceremonies were organised (Binder 2012: 279-283).

The first School Olympics in Estonia, recognised by the EOA, were held at Patküla Elementary School in Tõrva on May 9-11, 1996. The programme included several exciting events: Olympic essay contest, Olympic drawing contest, contest for creating the School Olympic mascot, sports contests - and naturally the festive opening ceremony with all the "real" Olympic traditions (parade of the participants, hoisting the flag, lighting the fire, Olympic oath) (Viru et al. 1999: 25-26). 
The first School Olympics were successful to an extent and encouraged the EOA to continue the project. In 2002 it was decided to turn the project from the level of local activities to that of a nation-wide movement (Ööpik 2004: 5).

The EOA encouraged schools to organise School Olympics following the principles of the Olympic Movement and, at the same time, supported the events financially. The launch was successful, since, within the first six years of the project, School Olympics all over Estonia were held with the participation of 358 schools and kindergartens and nearly 50,000 children (Remmelkoor 2009: $17-18)$.

\section{THE MODEL OF SCHOOL OLYMPIC GAMES IN ESTONIA}

Today the guidelines of the Estonian Olympic Academy give relatively comprehensive instructions for organising School Olympics. According to these, School Olympics are not merely sports competitions, but also a cultural and educational event. An important part of it is the Olympic Education week, during which children acquire knowledge about Olympic history, the ideas of the Olympic Movement and the best athletes.

Naturally, the highlight of School Olympics is the sports festival, which follows the universal Olympics model, including the opening ceremony, sports competitions, cultural programme and closing ceremony accompanied by all the Olympic rituals (see also the EOA web page http://www.olympiaharidus. eu/index.php?page=72\&).

The participant schools have a free hand in outlining their own Olympic programmes, choosing the number and nature of the contests, sports disciplines, prizes, etc. Although the wishes, organising skills and technical possibilities of schools are on different levels, there is one common characteristic typical of Estonia - the use of traditional sports in the competitions programme. This interesting tradition has its roots in the early days of School Olympics in Estonia and - since the pioneer-games with traditional events in the programme were received very positively and emotionally - it started to spread in the hope of making the games more interesting both for the participants and the spectators. As this tradition proved its vitality, the EOA today actively recommends using non-regular sports in the programme. 


\section{EXAMPLES OF TRADITIONAL SPORTS USED IN SCHOOL OLYMPICS IN ESTONIA}

The variety of sports used at different times in different places is wide - starting with Estonian popular traditional sports, known from the innumerable summer festivals and "good mood events" (tug-of-war, traditional relays, sack race, etc.) and ending with the imitation of the traditional sports of ancient Greece (chariot race, long jump with halteres, etc.), not to mention the new colourful disciplines born out of local traditions, interests and organisers' imagination. Competitions are held even in non-sportive events like potato digging or crocheting (Remmelkoor 2008: 14). Below are examples of different sports that throughout the years have been included in the School Olympic Games, according to the categorisation given by the author.

Popular traditional sporting events in the programmes of School Olympics in Estonia: tug-of-war, stick-pulling, weight throw, boot throw, log throw, medicine ball throw, kettlebell lifting, arm wrestling, strongman contests, cartwheel rolling, wife carrying, sack race, last man's race, standing long jump, archery, dodgeball, sledge racing, snowball throwing at a target, sliding on ice.

Imitated ancient sporting events in the programmes of School Olympics in Estonia: armed race, shield race (both originating from ancient military hoplite race), chariot race, stadion race, long jump with halteres, triple jump with halteres, long jump with a shield, javelin throw, wrestling, Japanese sumo wrestling.

Newborn sporting events in the programmes of School Olympics in Estonia: pushball-football (football with a ball from pushball game), horseback racing with brooms, pillow fight, fire fighting olympics (competition for fire fighting skills), math race (running + mathematics), Formula 1 relay race, team long jump, mammoth hunt (target throwing at a mammoth figure), "Hit the nail!" (competition for hitting nails into a log), snow football, sledge slalom, sledge relay race, tandem skiing.

\section{Ancient Olympic Games in Nõo Gymnasium}

The positive impact of the first Nõo School Olympics in ancient style (held in 1999) gave an impetus to the adoption of traditional sports into the Olympic programmes in Estonia. According to the organisers, the reason for choosing the ancient style came from a desire to create their own original tradition, to do things differently and follow the ancient roots of the Olympic Games in Greece (EFA, KP 103: 95-96). 
The programme of the 1999 games in Nõo included stadion race, chariot race, weight throw, tug-of-war, sumo wrestling, shield run and pushball (ibid.). While most of these events (even Japanese sumo!) were held by the classical rules, the most attractive event - chariot race - was completely redesigned. As there were no real horses and competition chariots available, the organisers decided to use an old horse cart instead of the chariot and young boys instead of horses. Each team also had a girl for a charioteer to motivate the boys. The goal was to run one lap with the chariot around the school stadium, one by one (as there was only one chariot available) and the winner was the team with the best lap time. The extraordinary spectacular chariot race conquered the hearts of the audience and became a legend. It is still in the programme of the Nõo Games, and it is also copied by many other School Olympics in different places all over Estonia.

In 2013, the School Olympics in Nõo were already being held for the eighth time - and still in ancient style. The programme of the games has not changed much during the years and the games have become an inseparable part of the school tradition (ibid.: 98-101).

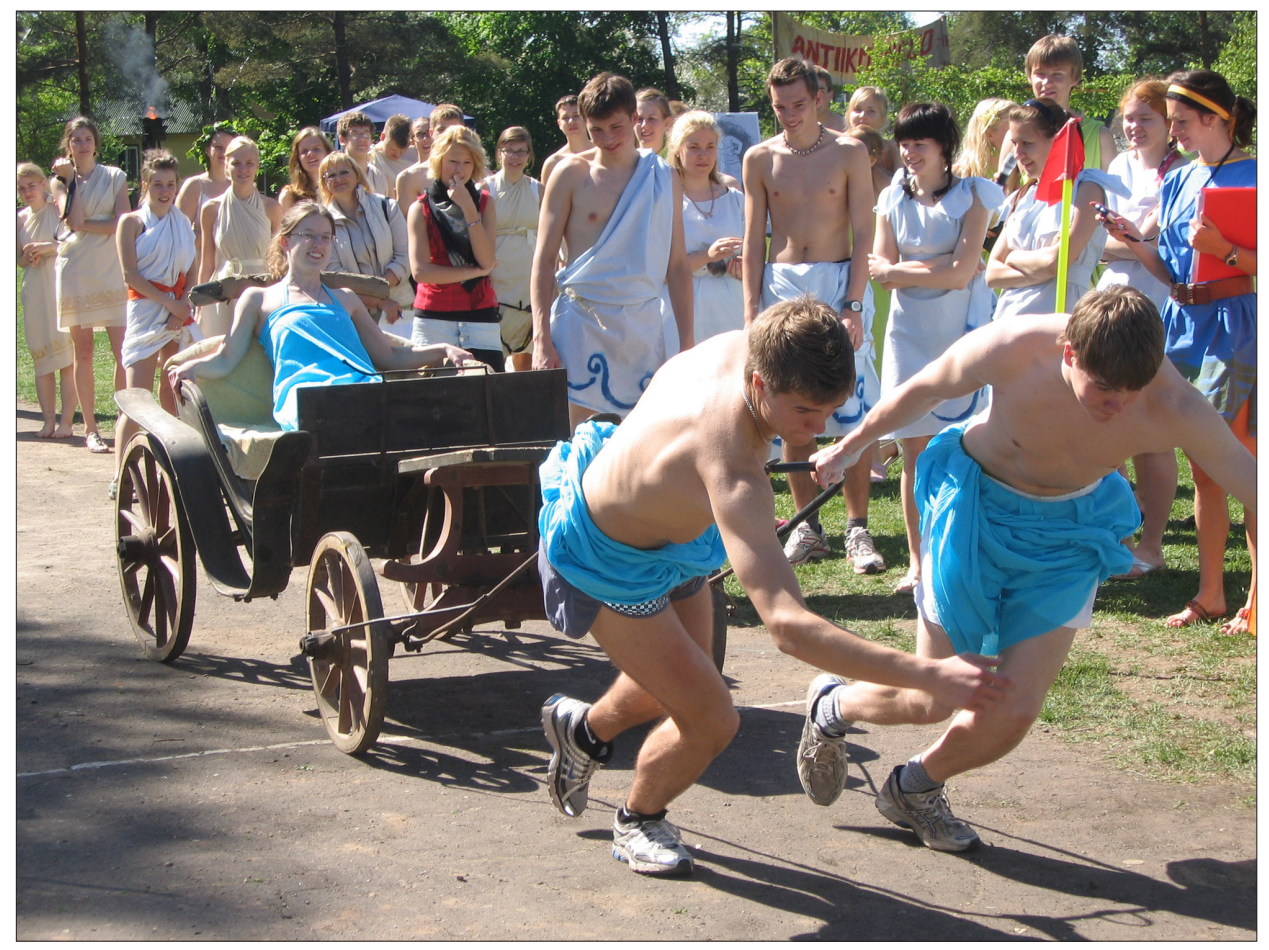

Figure 1. Ancient sport in modern style. Chariot race at Nõo School Olympic Games in 2009. Photo by Reele Remmelkoor. 


\section{School Olympic Games in Setomaa}

The School Olympic Games with a strong local cultural character are held in Setomaa, a historic region south of Lake Peipus, which is inhabited by the Seto people, an ethnic and linguistic minority group in south-eastern Estonia with their own cultural traditions. Historic Setomaa is located on the territories of present-day Estonia and Russia.

The School Olympic Games tradition in Setomaa is a good example of crossborder cultural cooperation, as along with the schools of the Estonian side of Setomaa children from Petseri (Pechory) (small town in the Russian part of Setomaa) also participate.

In 2012 the 4th School Olympic Games in Setomaa were held, with the participation of children from all the schools currently operating in the historic Setomaa area: Mikitamäe, Meremäe, Misso, Petseri and Värska. The games were an expression of the strong ethnic unity of the Seto people and their still existing respect towards their own roots. The opening words of the games were given by Aarne Leima, the sootska ('king') of the Seto people, and the Olympic flame was lit on Jumalamägi Hill (God's Hill) in Kolosova village, next to the statue of Peko, a Seto god (Lätt 2010).

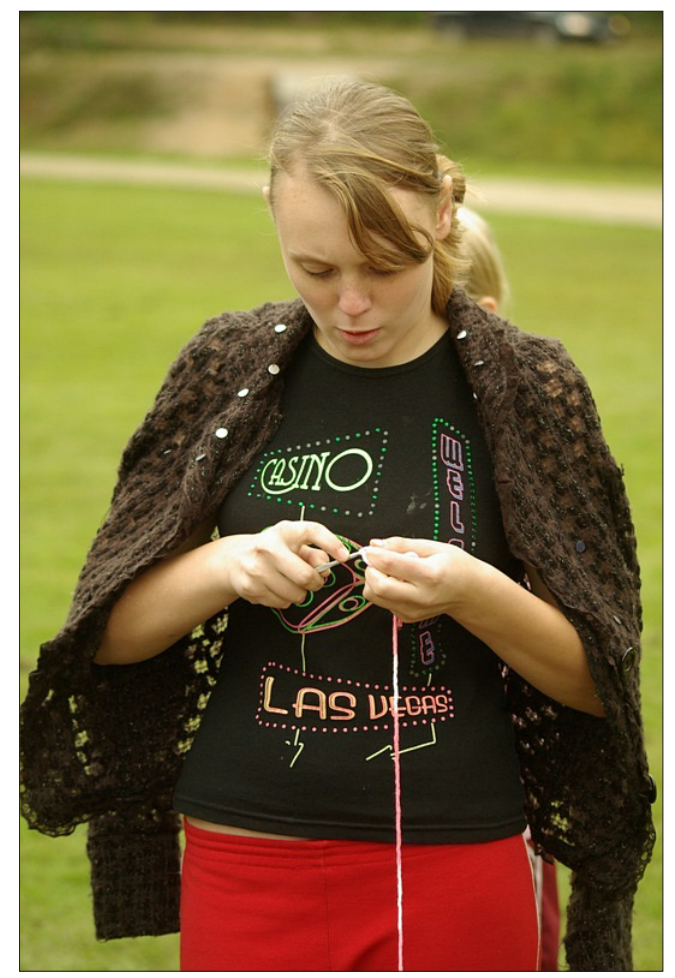

The ethnic traits of the Seto people were revealed also in the competition programme, the most attractive part of which was the electing of the Setomaa Noorik (The Maiden of Setomaa) and the Setomaa Vägilane (The Strongman of Setomaa). Both competitions consisted of a few unique events associated with the local traditions. The participants of

Figure 2. Globalising world: Seto girl, Las Vegas T-shirt, traditional jacket and crocheting competition all in one, at School Olympic Games in Setomaa in 2008. Photo by the Estonian Olympic Academy. 
the Maiden contest had to dig up a bucketful of potatoes, to demonstrate their skills in crocheting and to jump with a skipping rope, while the candidates for the Strongman title had to show their skills in different traditional heavy athletic events, such as holding dumbbells, carrying logs, etc. (see Lätt 2010).

\section{School Olympic Games on Kihnu Island}

A very special School Olympics tradition was born on Kihnu Island, a small island in the Baltic Sea. With an area of $16.4 \mathrm{~km}^{2}$, it is the seventh largest island in Estonia. The population of the island is approximately 600 people, who speak a dialect of Estonian which is sometimes considered as a distinct language. UNESCO even proclaimed the Kihnu cultural space and traditions as a Masterpiece of the Oral and Intangible Heritage of Humanity on November 7, 2003.

The first Kihnu Olympic Games were held in 2005. The programme of the first games consisted of events with both a modern and traditional character, including, for instance, stadion race, fishing net throw, race of beautiful maidens (girls running with a bowl full of water), etc. (see Võsu 2005: 2).

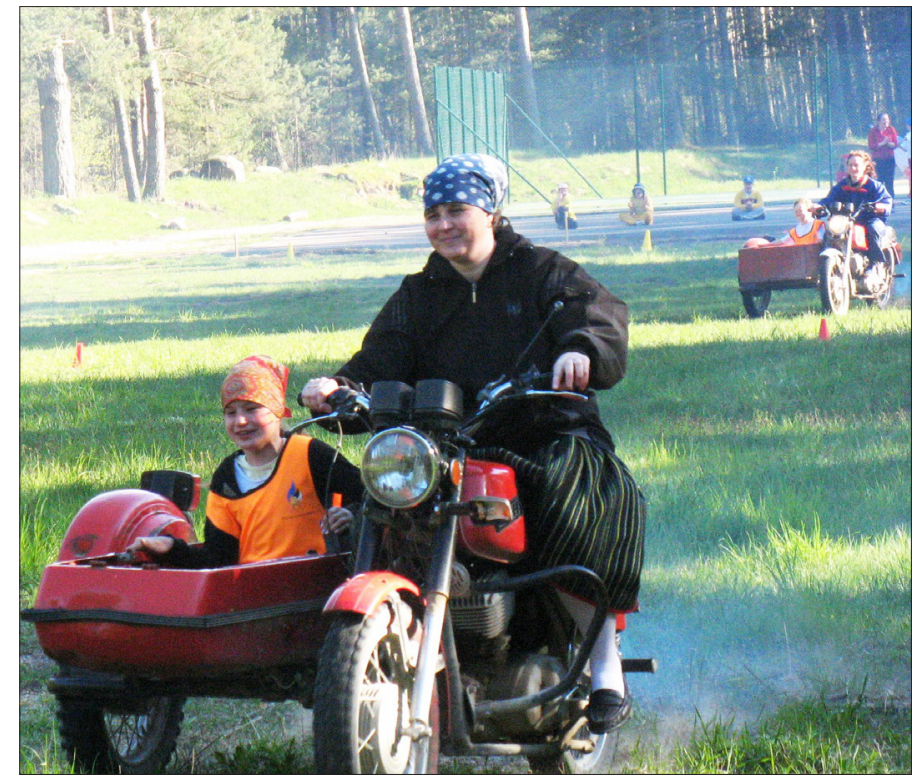

Figure 3. Kihnu woman with her child competing at the sidecar motorcycle race at Kihnu School Olympic Games in 2007. Photo by the Estonian Olympic Academy. 
History was made at the Kihnu Olympic Games of 2007 - the first sidecar motorcycle competition of the island was held, where drivers were mothers wearing their folk costumes (with beautiful long skirts) as they always do, and co-drivers were their children (Saare 2007). This unique competition was included in the games because the sidecar motorcycle is a traditional means of transport for women of Kihnu Island and is also one of the symbols of the island.

\section{Tootsi School Olympic Games}

Interesting School Olympic Games were held in Tootsi rural municipality in 2010, as a united effort of the Tootsi kindergarten and Tootsi Elementary School. These games had a literary context due to the similarity of the names of Tootsi rural municipality and one of the main characters - called Joosep Toots - in the popular novel Kevade (Spring) by a renowned Estonian writer, Oskar Luts. The organisers were encouraged to undertake this challenging task by the fact that this evergreen novel reflects the life and activities of Estonian schoolchildren.



Figure 4. Pillow fight at Tootsi School Olympic Games in 2010. Photo by the Estonian Olympic Academy. 
The programme of the Tootsi Games included several competitions with names influenced by Oskar Luts's novel. The target throwing competition, for instance, was called "Hit until fixed!" (the name was derived from the popular catchphrase from the novel Kevade); the tug-of-war competition was called "Pulling Teele's braid" (Teele was the main girl-character in the novel Kevade, who was braidpulled by Toots); also there was a team event under the name "Rolling Toots's globe" (as in the novel curious Toots made a personal globe for himself), and another team event "Pass the kringle!" (as kringle with many raisins in it was one of Toots's favourite dishes) (Raudsepp et al. 2010: 1).

\section{IN CONCLUSION}

In many places of Estonia, the School Olympic Games have become an integral component of school traditions, helping to create the school identity and bind together different cultural layers. By their principles these games are more than just sport and competitions. With a different approach to sport, Olympic Games in schools can teach participants the central human values (fair play, friendship, tolerance), as well as creativeness and old national traditions.

\section{ARCHIVAL SOURCES}

EFA, KP - school lore collection of the Estonian Folklore Archives

\section{REFERENCES}

Binder, Deanna L. 2012. Olympic Values Education: Evolution of a Pedagogy. In: Educational Review, Vol. 64, No. 3, pp. 275-302, http://dx.doi.org/10.1080/0013 1911.2012.676539.

Lätt, Anneli 2010. Värskas toimusid Setomaa koolide IV olümpiamängud. [The 4th School Olympic Games in Setomaa were held in Värska.] Available at http:// www.polvamaa.ee/index.php?page $=875 \&$ action $=$ article\&article_id=15968, last accessed on July 1, 2013.

Naul, Roland 2008. Olympic Education. Oxford: Meyer and Meyer Sport.

Ööpik, Vahur 2004. Fifteen Years of the National Olympic Academy of Estonia. Acta Academiae Olympiquae Estoniae, Vol. 12, No. 1, pp. 5-6.

Raudsepp, Inga \& Põbo, Silvia 2010. 1. juunil toimusid Olümpiamängud Tootsis. [The Tootsi Olympic Games were held on June 1.] Tootsi Teataja (newsletter), No. 19, p. 1. Available at http://www.tootsi.ee/public/files/teataja20\%5B1\%5D.pdf12.pdf, last accessed on July 1, 2013. 
Remmelkoor, Reele 2008. Kooliolümpiamängud - kellele ja milleks? [School Olympic Games - For Whom and Why?] Opetajate Leht (newspaper), November 14, p. 14. Available at http://opleht.ee/arhiiv/?archive_mode=article\&articleid=539, last accessed on July 1, 2013.

Remmelkoor, Reele (comp.) 2009. Eesti Olümpiaakadeemia projekt "Kooliolümpiamängud". [Estonian Olympic Academy project "School Olympic Games".] In: Olümpiahariduse kogemused ja nü̈̈disaegsed suunad. Konverentsi teesid. [The Experiences and Modern Trends in Olympic Education: Conference Abstracts.] Tartu: Estonian Olympic Academy, pp. 17-18.

Saare, Anu 2007. Kihnu kool elas olümpialainel. [Kihnu School Was in the Olympic Mood.] Eesti Päevaleht (newspaper), May 21. Available at http://www.epl.ee/news/ eesti/kihnu-kool-elas-olumpialainel.d?id=51087700, last accessed on July 1, 2013.

Viru, Atko \& Kull, Merike \& Matsin, Tõnis \& Remmelkoor, Reele 1999. 10 years of the National Olympic Academy of Estonia. Acta Academiae Olympiquae Estoniae, Vol. 7, pp. 4-33.

Võsu, Ingrid 2005. Kihnu kooli olümpiamängud. [School Olympic Games in Kihnu.] Kyne (quarterly), June, p. 2. Available at http://kultuuriruum.ee/files/documents/ Kyne/Kyne_juuni_2005.pdf, last accessed on July 1, 2013.

\section{INTERNET SOURCES}

Web page of the Estonian Olympic Academy (EOA). Available at http://www. olympiaharidus.eu/index.php?page=72\&, last accessed on July 1, 2013. 


\title{
THE TRADITIONS OF FISTICUFFS IN THE NORTH-WEST OF RUSSIA FROM THE EARLY MIDDLE AGES TO THE MODERN ERA
}

\author{
Dmitry Belyukov
}

\begin{abstract}
Various forms of physical training were widespread in the national culture of the East Slavs. One of its original forms was fisticuffs. North-west of Russia was not an exception. There was a fisticuffs version called Skobar, which was practised in the territory where the Krivichi, the powerful union of the East Slavic tribes, used to live. One of the versions explains the word Skobar as an alteration of Pskovar, which denotes an inhabitant of the Pskov region.

Traditions of fisticuffs are known to have continued up to the second half of the 19th century. Their descriptions published in the magazine Pchela (The Bee) in 1878 have survived until today. So, for example, in Pskov fights were held 'wall on wall - in an avalanche', some hundreds of people on each side.

Other cities of the province were famous for fisticuffs as well. In Velikie Luki they were a usual youth entertainment at Christmastide and Shrovetide. Competitions were generally held in the city suburbs. City dwellers set out on a fight against peasants of Sergievskaya village, which was part of the city suburbs.

At the end of the 19th century fisticuffs were banned by the authorities. But this prohibition was not always observed. Writer Yury Tynyanov mentioned that during his schooldays (1904) fisticuffs were held between city suburbs that were at war, and the pupils of Pskov Grammar School participated in them.
\end{abstract}

Keywords: north-west of Russia, Pskov region, Krivichi, Skobar, city suburbs, fisticuffs

Already in ancient times various forms of physical training were widespread in the national culture of the East Slavs. One of its original forms was fisticuffs. It is a known fact that fisticuffs was practised by the Slavs in the 9 th century. But later on the custom of fisticuffs disappeared both by the West and East Slavs. So, the question stands: why has the custom of fisticuffs that disappeared at some Slavic tribes survived at the East Slavs? Historians maintain that it can be connected with the use of fisticuffs in military science. Russian statehood was formed in the conditions of constant struggle against the nomadic people of Asia. Later on, in the 13th-15th centuries, Russia sustained more than 160 wars with Tatars, Lithuanians, German knights, Swedes, Poles, Hungarians, Bulgarians, etc. 


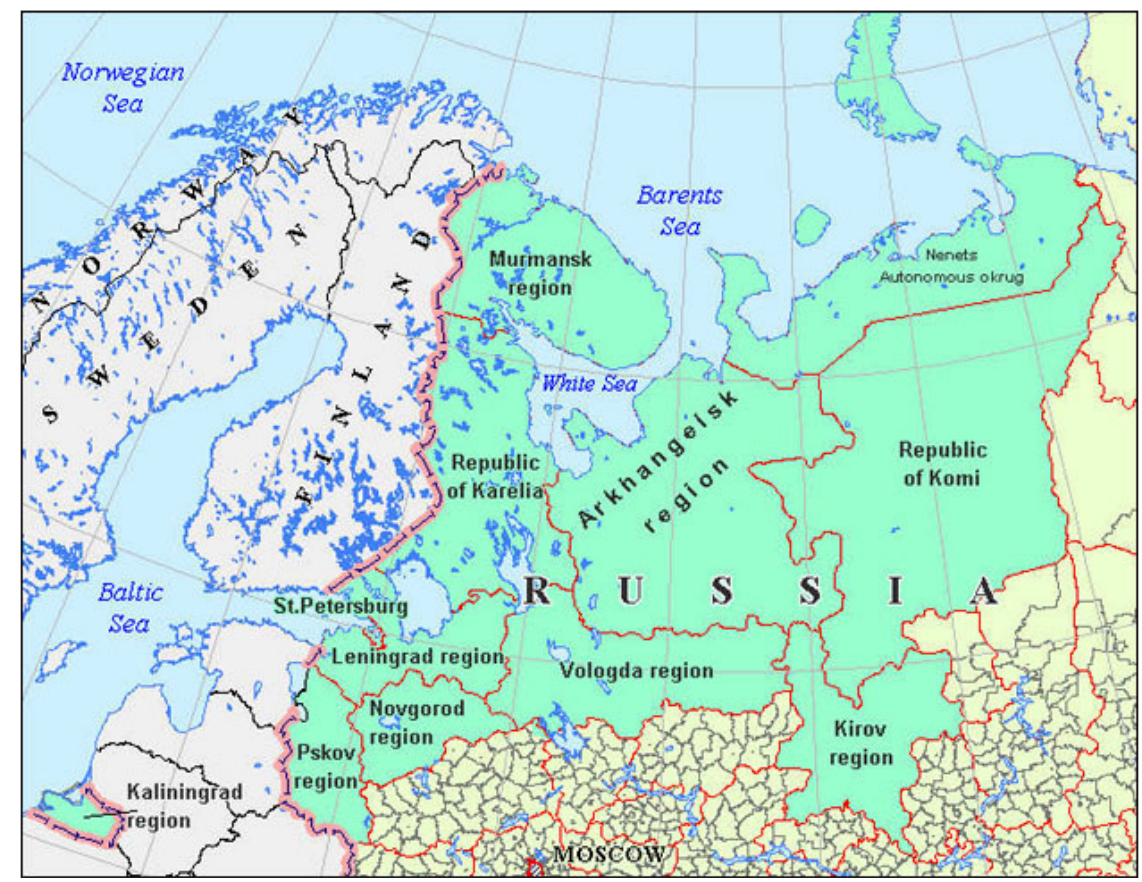

Figure 1. Map of north-west Russia. (http:/ /openbudget.karelia.ru/budnord/english / nord11_nav.htm)

Two principal kinds of fisticuffs were distinguished - group (wall on wall) and single (one on one). The fight 'one on one' was close to old English bare-knuckle boxing, but differed from it by its smaller cruelty. Before beginning the fight, the contestants embraced three times and kissed each other, showing the absence of any enmity between them. In case one of the fighters fell, the fight was stopped, while in English boxing beating of the lying contestant continued (it was banned only in 1743) (Goloshchapov 2007: 77-78).

However, mass fights 'a wall on a wall' were the most favourite and the most widespread in Russia. In group fisticuffs streets, city districts, and villages usually met, and participants were grouped according to age. As a rule, fights were arranged on holidays - in special places in the summer, on the ice of frozen rivers and lakes in the winter. Fisticuffs was formed and became established during less than one century. The first important step was full elimination of stick fighting. Fisticuffs became an exclusively unarmed fight. Further on, kicking was forbidden as well as the use of feet for throws. In many districts there were differences in rules, but in due course they became almost uniform for all Russia. 
At the same time in the upper class, among the nobility, a negative and contemptuous attitude towards fisticuffs strongly persisted. The majority of Russian tsars tried to ban the practising of the fight but all their attempts appeared to be in vain. There were objective reasons for that. Fisticuffs was an embodiment of military preparation in physical training.

Participants in the fights were to observe unwritten but strict rules: not to beat the downed opponent, not to hide anything in the gloves, fight face to face, breast to breast, not to trip, etc. (Stolbov \& Finogenova \& Melnikova 2001: 112-113).

Popularity and love of Russian people for this entertainment is reflected in the literary works of outstanding Russian writers: A. Pushkin, M. Lermontov, L. Tolstoy, A. Gorky, M. Sholokhov, etc., and depicted by artists I. Repin, V. Vasnetsov, M. Vrubel, etc., and composers A. Borodin, A. Grechaninov, etc.

In The Legend about Ivan Vasilevich, Young Oprichnik and Kalashnikov's Bold Merchant, M. Lermontov described the fisticuffs between the tsar's oprichnik Kiribeevich and merchant Kalashnikov. Kalashnikov won, having defended

Figure 2. V. Vasnetsov. Kiribeevich fighting with merchant Kalashnikov. 1891. (http:// panevin.ru/calendar/big / ukaz_o_zaprete_kulachnih_boev. html)

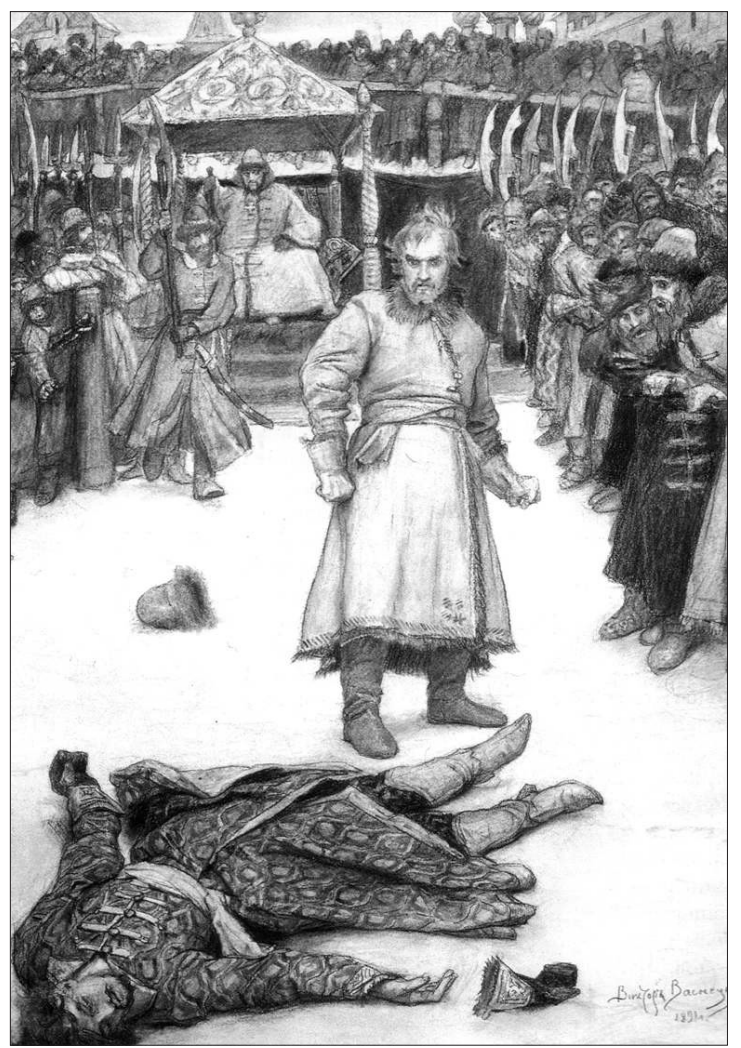


the honour of a lady offended by Kiribeevich, and "having stood for the truth to the end", but he was later on executed by tsar Ivan Vasilevich (Lermontov 1988: 515-529).

Maxim Gorky in the novel Matvey Koshemyakin's Life has described the fisticuffs as follows:

Townspeople carry on the fight cunningly [...] move out of their 'wall' against the mass of settlement dwellers about five good fighters, and when settlement dwellers, charging at them, involuntarily try to force their way like a wedge, the townspeople unanimously strike from the sides, trying to crush the enemy. But the settlement dwellers are used to these manners: they quickly withdraw and seize the townspeople in a semicircle... (Gorky 1949).

In each fight, in particular a very crowded one, some of the contestants were heavily beaten, crippled or even killed. On the trampled snow, on the river ice, there were motionless bodies lying around, and their companions took them away, or sometimes the police interfered. The victims' involuntary, casual mutilations could not specify if it was a matter of revenge, enmity or something else. And how to save yourself, when in a heat of passion, in the crowd, a blow is delivered unintentionally by such part of the body that injures or even causes death.

One of such cases took place in 1823 during the travel of the Emperor Alexander I to the south. The emperor was dissatisfied with the incident and

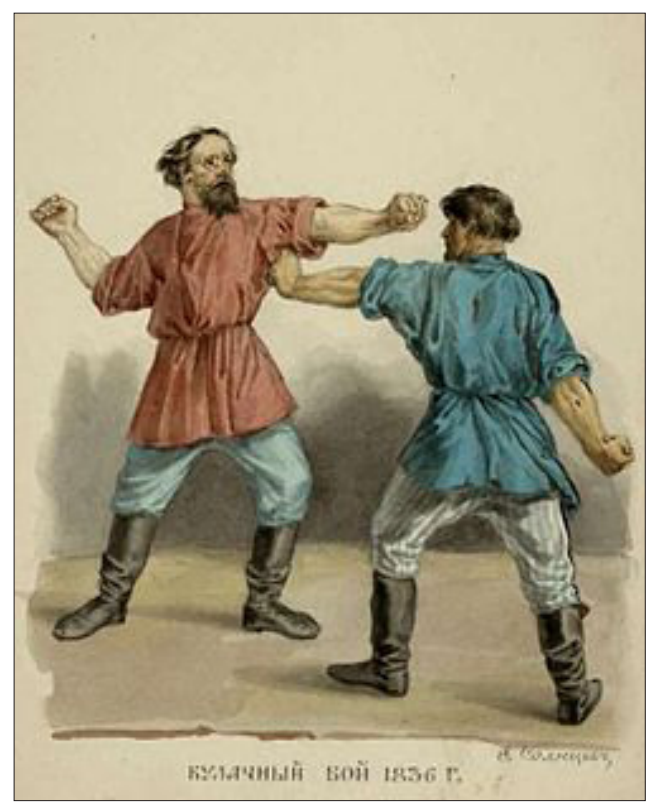
issued a decree as of October 20 to ban fisticuffs.

Prohibition of the fisticuffs was included into the Code of Laws of the Russian Empire in 1832 (Volume 14, part IV, article 180) (Code of Laws 1832): "The fisticuffs as harmful entertainment is completely forbidden". The same is literally repeated in the editions of $1839,1842,1857$, 1876 and 1890.

Figure 3. F. Solntsev. Fisticuffs. 1836. (http://www.posterlux.ru/ rus-artists/gallery/solncev-fedorgrigorevich-1801-1892/9685/page/1) 
Nevertheless, the fisticuffs was practised almost everywhere, even in the capital, although in the latter it was practiced not so often and not in such volumes.

Certainly, the north-west of Russia and the Pskov region were not an exception. There was even a variant of fisticuffs called Skobar, in which lines of ceremonial dancing can be easily recognised. In the Pskov region its name is not only Skobar but also 'affectation', which means to pretend or dance as a drunken person. In general, a similar dance can be met all over the territory where the Krivichi - the powerful union of the East Slavic tribes - used to live.

One of the versions explains the word Skobar as an alteration of Pskovar, which denotes an inhabitant of the Pskov region. They pretended to be drunk when dancing to a folk tune played on the accordion. The motive was simple, rhythmical enough and, probably, that served a definite purpose. Gradually the dancer, submitting to the rhythm, entered a certain mental condition. While dancing Skobar, having a rest from work and having fun on a festivity, a person, as a matter of fact, practised for a fist or stick fight. Ceremonial fights were also held to the accompaniment of music. The rules varied; for example, the fight lasted to the first blood or to the first fall. The accordion player (in the earlier times psaltery player) could stop the fight by stopping playing the tune. In this case, we can say that music had full power.

At the beginning of the 'affectation' the dancer shook his head or tousled his hair. These actions, certain exclamations (whooping) and stamping were considered as elements of the ancient folk magic. The person left his usual everyday space and entered another level of existence. Time flew differently, and sensory organs worked in a different way, and in general, the attitude to life or death was different. Therefore this awkward dance would actually serve rather as a cunning and effective preparation for fisticuffs. The relaxed body of a Skobar was ready to react not only to the actions of the rival, but even to a breeze whiff.

'Affectation' gradually passed into a ceremonial fight. This fight is a relic heritage of those times when men battled for a woman in a marriage fight. One of its names is Yar. On the other hand, the word 'Yar' meant vital force and its display in the Slavic languages. Considering themselves descendants of Dazhdbog - the god of Sun, or Yarila, they lived according to a solar calendar, and used vital energy in the struggle, in other words, the energy that was controlled by solar plexus.

Prepared for a serious fight by ceremonial 'affectation', in a critical situation a Skobar could join an internecine fight - to the complete annihilation of the opponent. A trained fighter could strike 5-6 blows a second. Such speed was defined by the principle of dance movements. To knock the opponent down, a Slav just needed to strike an indirect sliding blow. And it was better if it was 
delivered on a curved trajectory - the hand came back without a delay while another hand came nearer to the target. Such speed was important in the fight with several opponents, especially when in the encirclement (Retiunskikh \& Zaiashnikov 1991: 4-5; Gruntovskii 1998).

Traditions of the fisticuffs can be followed up to the second half of the 19th century. Their descriptions were published in 1878 in the magazine Pchela. So, for example, in Pskov, fights were held 'wall on wall - in an avalanche', some hundreds of people on each side. The fisticuffs was started by bullyboys due to some quarrel contrived in advance. Pushing each other, they started a formal fight from a tip-and-run attack.

"Hey, with a tip-and-run fight, from the front, from the sides, from heels to tops, I shall beat you up!" they shouted in thin voices, rolling up their sleeves and spitting on their fists. "Beat as you want, just don't touch the face, people say it is shameful!" (Krapivina 2000: 306-307).

Having started a tip-and-run fight to tease the senior fighters, kids used to be carried away by it and became so furious that they broke each other's noses, and their mothers would only sigh, watching the shreds of their red shirts fly up. But they did not stop the fighters as they were the 'leaders' to whom adult winners would buy new shirts. When they absolutely lost control, the 'real' fighters who were silent spectators of the attack to that moment, would take

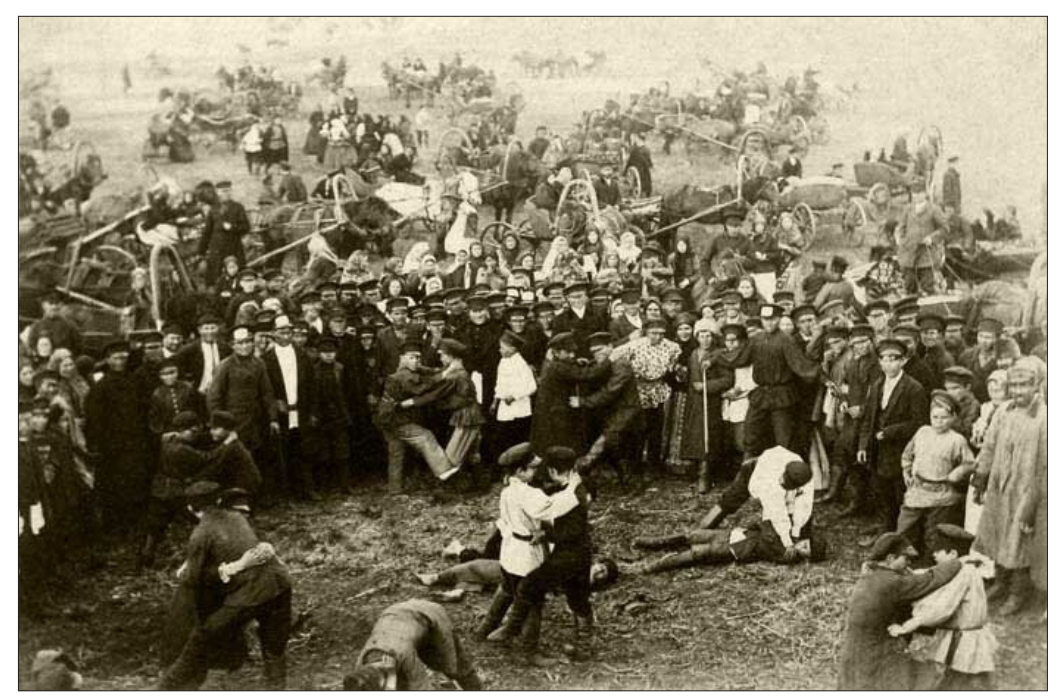

Figure 4. Fisticuffs. 1900. (http://fun247.ru/30.11.2012/vzglyad_v_istoriyu.html) 
them aside. After that the terrible 'valiant fun' began. There was always human blood, human bodies moaned and groaned under strong blows, and the crowd was delighted, both women and children's screams and men's curses were heard (ibid.).

Memories of the outstanding Pskov dwellers testify to the traditions of the fisticuffs. One of those sharing their memories was Yury Tynyanov (1894-1943), a Russian Soviet writer, playwright, literary critic, and the author of the novels Pushkin, Kukhlya, Vazir-Muhtara's Death, Second Lieutenant Kizhe, etc.

According to Yury Tynyanov, who entered Pskov Grammar School in 1904, in the first years of his studies fisticuffs was held between the city suburbs Zapskovie and Zavelichie that were at war with one another, and the pupils of the grammar school participated in them. Both sides beat the fighters for the coins clamped in the gloves (Tynyanov 2003: 112).

Other cities in the province were also famous for fisticuffs. In Velikiye Luki it was a usual youth entertainment at Christmastide and Shrovetide. Fisticuffs generally took place in a place named Butyrki where there was a district hospital later on. Now this place is known as a 'hospital town'. City dwellers set out on a fight against the peasants of Sergievskaya village, and even the officials took part in it. Sometimes fisticuffs ended very badly, some participants had battered faces, and others would even stay in bed. At the end of the 1860 s, the police made every effort to stop such wild entertainment. Later on the youth occasionally showed their mighty force, under the influence of booze; at night they broke bridges and benches in parkways and streets, but they seldom showed their strength on people (Pul'kherov 1893: 78-79).

At the end of the 19th century fisticuffs was finally forbidden by the authorities. But physical strength was always respected in Russia, as well as a perfectly developed body. When a travelling circus came to the district cities, all the citizens went to watch its shows. Athletes broke horseshoes, juggled with twopood (33.6 kilograms) weights, knotted thick iron rods, lifted a wooden platform with ten spectators on their shoulders and wrestled with a bear. Many items in these 'shows' were invented by Estonian Georg Lurich, the world wrestling champion, who visited Velikiye Luki. It should be mentioned that his build was considered to be one of the best in Europe. It is known that the fighter posed for a well-known sculptor Rodin (Lopyrev 2003: 124).

Greco-Roman wrestling tournaments were extremely popular among the citizens of Pskov. Well-known foreign sportsmen were invited to take part in them. German Kentel, a world champion, visited Pskov on the eve of the First World War. During one of the fights he was defeated by an unknown smith of Pskov factory Metallist (Krasnopevtsev 1961; Krasnopevtsev 2002: 170-181). 
The first Russian boxers began as fisticuffers. Among them were Nur Alimov, Paul Nikiforov, etc. But it was not only representatives of wrestling and boxing that passed the remarkable school of fisticuffs. For example, the Starostin brothers well known in Russia (the founders of the sports society Spartak) spoke about this hobby with gratitude. Nikolay Starostin recollected:

Hand-to-hand fights ('wall on wall') were very popular in Moscow before the revolution... And group fights ('walls') had their own traditions. Some hundreds of people on each side took part in them. It could seem that it was a usual mass fight, a real slaughter. Actually it was a well-prepared show with its own stars and idols. As a rule, this kind of entertainment took place on Sundays and started usually at 10 a.m.

The spectators gathered on the coast of the Moskva River. Their number increased up to ten thousand by 3 or 4 p.m. 'Hand-to-hand' fights were held on ice ...

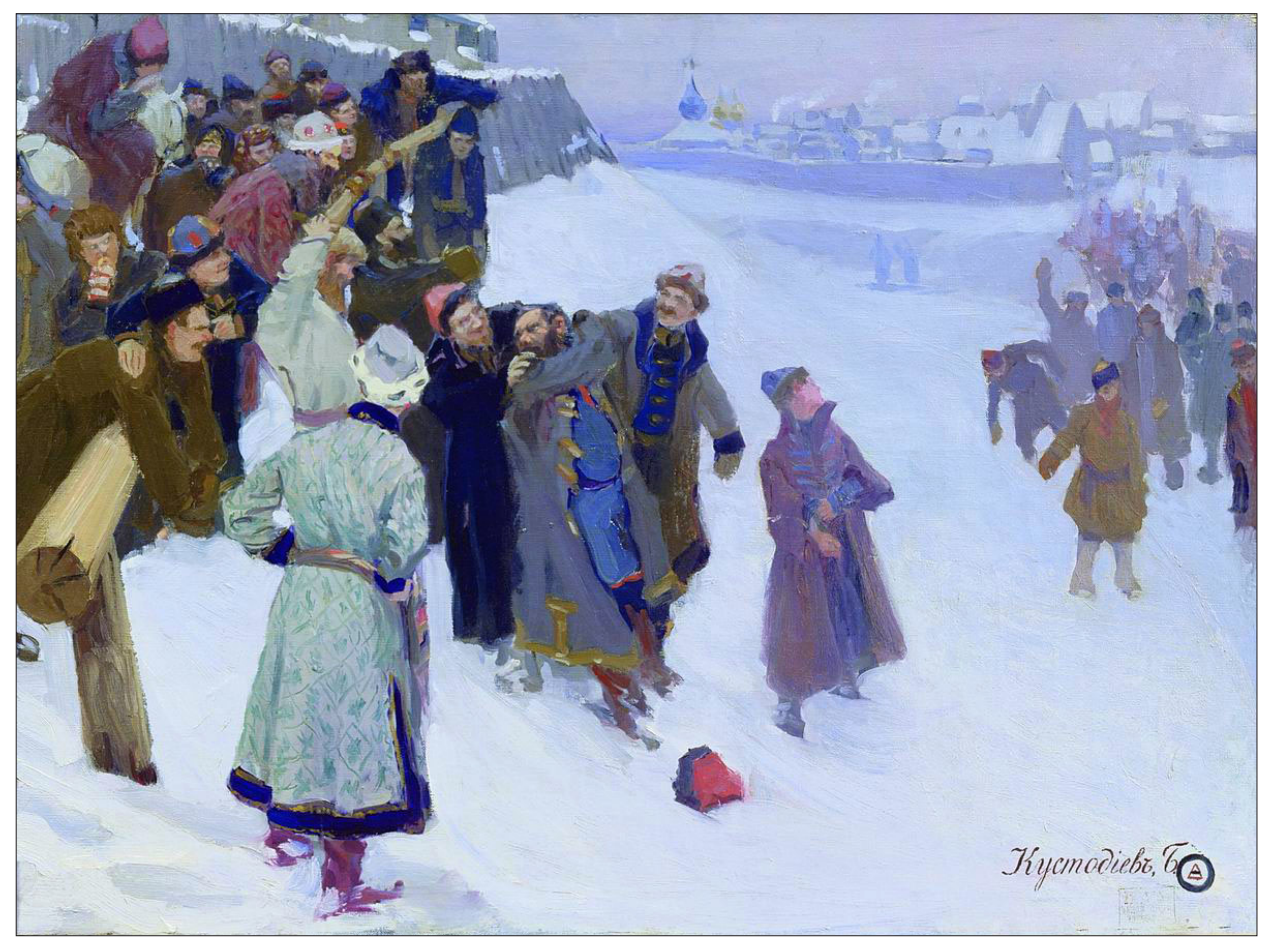

Figure 5. B. Kustodiev. Fisticuffs on the Moscow River. 1897. (http: / /5147690.ru/reproduktsiyakartiny-kulachnyi-boi-na-moskva-reke) 
The majority of us chose the opponent beforehand. As a rule, he was the same every time because we knew each other not the first year and tried, by the tradition of 'walls', to do so that opponents were approximately equal in strength ...

Certainly, our fight could not end in anything more dangerous than a bruise under an eye or a broken nose. Gloves on our hands softened blows, clothes and the lifted collars protected weak spots reliably. But we got badly tired. In order to rest, we sat down on ice and wiped sweat, sometimes mixed with blood ...

We were assured up to the end that we had won. On the opposite coast our opponents triumphed as well. This constituted a favourable emotional background of the notorious 'walls'. They did not produce enemies, did not sow civil strife, nor did they foster cruelty and revenge ...This way our characters were forged. In due course we began to take pride in participation in the 'walls'. Moreover, I am convinced that fair struggle and respect for the opponent, which became the idea of my existence in sports, originate in those 'hand-to-hand' fights on the Moskva River in 1916. (Goloshchapov 2007: 79-81)

The picture of national culture cannot be considered complete if the researcher has overlooked any of its components, and thus the logic of the studied ethnic culture has collapsed. Studying the local forms of national culture of the East Slavs is impossible without a reference to the traditions of hand-to-hand competitions.

The zone of the formation and evolution of the fisticuffs traditions by the East Slavs was the north-west of Russia, in particular the territory of modern Pskov area. Initially these lands were occupied by the East Slavic tribes of Novgorod and Krivichi, which allows us to see in the culture of fisticuffs a heritage of the ancient Slavic population of these territories.

So the fisticuffs traditions have a long history in the folk culture of Russia, extending from the Late Middle Ages until the beginning of the 20th century.

\section{REFERENCES}

Code of Laws 1832 = Polnoe sobranie zakonov Rossiiskoi imperii v 45 tomakh. [Code of Laws of the Russian Empire in 45 Volumes.] 1832. Sankt-Peterburg: Tipografiia Vtorogo otdeleniia Sobstvennoi Ego Imperatorskogo Velichestva kantseliarii.

Goloshchapov B. 2007. Istoriia fizicheskoi kul'tury i sporta. [History of Physical Education and Sport.] Moskva: Izdatel'skii tsentr Akademiia. 
Gorky 1949 = Gor'kii Maksim 1949. Zhizn' matveia Kozhemiakina. Sbranie sochinenii $v$ tridtsati tomakh. [Matvey Koshemyakin's Life. Collected Works in Thirty Volumes.] Moskva: Gosudarstvennoe izdatel'stvo khudozhestvennoi literatury.

Gruntovskii, A. 1998. Russkii kulachnyi boi: istoriia, etnografiia, tekhnika. [Russian Hand-to-Hand Fight: History, Ethnography, Technique.] Sankt-Peterburg: TOO Tekhnologiia avtomatizirovannykh system.

Krapivina, S. 2000. O pskovichakh (nechto v rode etnograficheskogo ocherka). [About Citizens of Pskov (some kind of ethnographic essay).] In: E. Ivanov (ed.) Sbornik dokumentov i materialov po istorii Pskovskogo kraia (IX-XX vv.). [Collected Documents and Materials on the History of Pskov Region (9th-20th cc.] Uchebnoe posobie. Pskov, pp. 304-315.

Krasnopevtsev, Valentin 1961. Poddubnyi v Pskove. [Poddubny in Pskov.] Molodoi Leninets (newspaper). Pskov, October 14.

Krasnopevtsev, Valentin 2002. Iz istorii pskovskogo sporta. [From the History of Sport in Pskov.] Pskov (journal), No. 17, pp. 170-181. http://pskgu.ru/projects/pgu/storage/ PSKOV/ps17/ps_17_22.pdf, last accessed on June 17, 2013.

Lermontov, Mikhail 1988. Pesnia pro tsaria Ivana Vasil'evicha, molodogo oprichnika $i$ udalogo kuptsa Kalashnikova. [The Song of Tsar Ivan Vassilevich, His Young Oprichnik, and the Stouthearted Merchant Kalashnikov.] Vol. 1. Moskva: Izdatel'stvo Pravda.

Lopyrev, Andrei 2003. U sporta muzhskoe litso. Velikolukskie byli. Istoriia kraia v dokumentakh i ocherkakh. [Sport Has a Masculine Face. Velikiye Luki Epics. History of the Region in Documents and Essays.] Pskov.

Pul'kherov, Aleksandr 1893. Obrazovanie i obrazovatel'nye sredstva v gorode Velikie Luki i ego uezde. Istoriko-statisticheskii ocherk. [Education and Means of Education in Velikiye Luki and its District. Historical-Statistical Essay.] Pskov: Tipografiia Pskovskogo gubernskogo statisticheskogo komiteta.

Retiunskikh, A. \& Zaiashnikov, S. 1991. Russkii stil' rukopashnogo boia (Stil' Kadochnikova). Metodicheskoe posobie dlia zanimaiushchikhsia russkim stilem rukopashnogo boia. [Russian Style of Hand-to-Hand Fight (Kadochnikov Style). Manual for Russian Hand-to-Hand Style Fighters.] Novosibirsk: Vest'.

Stolbov, V. \& Finogenova L. \& Mel'nikova, N. 2001. Istoriia fizicheskoi kul'tury i sporta. [History of Physical Education and Sport.] Moskva: FiS.

Tynyanov 2003 = Tynianov, Iurii 2003. Avtobiografiia. [Autobiography.] In: T. Veresova (ed.) Vnachale zhizni shkolu pomniu ia.... Lev Zil'ber, Veniamin Kaverin, Avgust Letavet, Nikolai Neigauz, Yury Tynyanov - o vremeni i o sebe. [I Remember School at the Beginning of My Life ...: Lev Zil'ber, Veniamin Kaverin, August Letavet, Nikolai Neigauz, Yury Tynyanov - About Times and About Myself.] Moskva: Moskovskaia Tipografiia. 


\section{NEWS IN BRIEF}

\section{DOCTORAL THESIS ON THE SPATIAL SEMANTICS OF LOCATIVE CASES IN THE KOMI LANGUAGE}

On December 27, 2012, Nikolay Kuznetsov defended his doctoral thesis Prostranstvennaia semantika mestnykh padezhei komi iazyka (kognitivnyi analiz) (Spatial Semantics of Locative Cases in the Komi Language (Cognitive Analysis)) at the Institute of Estonian and General Linguistics of the University of Tartu (supervisor Docent Tõnu Seilenthal, opponent Cand. Phil. Galina Nekrasova from Syktyvkar).

Linguistic units expressing spatial relations are currently one of the most widely investigated objects in linguistics. A plethora of researches have been dedicated to the semantics of spatial markers in different languages, and a number of treatments have been presented from typological, contrastive and cognitive aspects. The semantics of the locative cases in the Komi language has also been repeatedly investigated (e.g. Evgenii Guliaev, Galina Nekrasova, Maria Usachova); yet, it is the first time that it has been treated from the viewpoint of cognitive linguistics. This proves the topicality of the scientific problem formulated in the dissertation. This research subject is topical not only from the point of view of the linguistics of the Komi language, but also from the viewpoint of Permistics as a whole, as the grammatical system of the Permian languages has not yet been investigated from the aspect of cognitive linguistics.

The dissertation aims to describe and present a cognitive analysis of the spatial meanings of locative cases in the Komi language. Proceeding from this objective, the

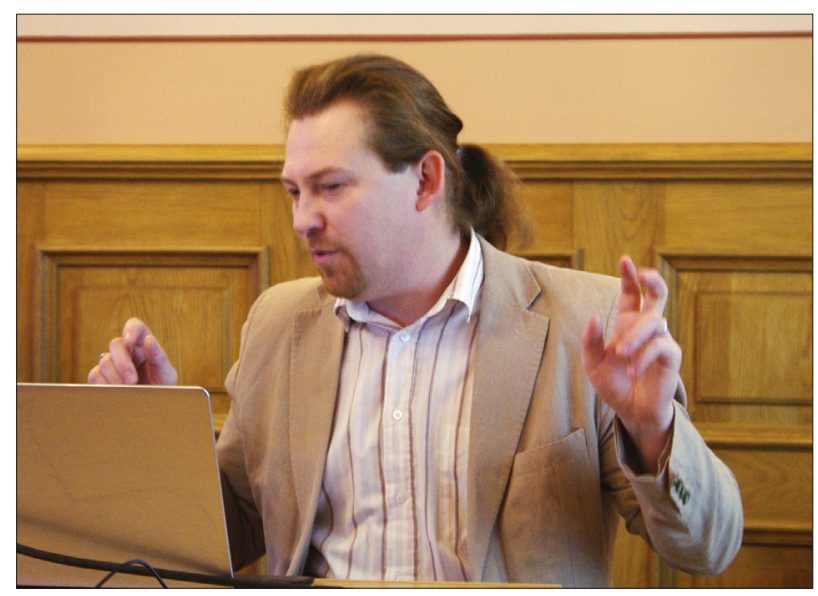

Nikolay Kuznetsov. Photo by Andres Kuperjanov 2012. 
dissertation groups the locative cases in the Komi language; presents the inner structure of the meaning system of locative cases as a matrix of cognitive domains; presents examples of the use of locative cases in different spatial functions; views spatial meanings from the aspect of centre and periphery and describes mutual relations between prototypical and peripheral usage cases; analyses more specific spatial meanings from the viewpoint of their categorical belonging.

In the subchapter "Case" the author explains the concept of the case, presents data about the category of case in different languages, including Finno-Ugric languages, and classifies cases. An important factor in the semantics of locative cases is the description of spatial situation elements presented in the dissertation: localisation, orientation, the topological type of landmark. The research history of locative cases has been described quite specifically, especially the earliest treatments. In the voluminous subchapter "Cognitive Approach in Linguistics" the author presents theoretical foundations of cognitive linguistics (its evolution, main principles and content), which proves that he has good knowledge of the relevant theoretical literature and is able to analyse the material and make conclusions. R. Langacker's theory has been most persistent in following the main principles of cognitive linguistics in the treatment of natural language grammar, which accounts for the more detailed description of the main ideas of this theory in the dissertation. A significant subchapter here is also "Structure of Meaning. Polysemy", as its content has a direct relation to the research object. It presents possibilities for describing polysemic linguistic units and explains the concepts of semantic network, prototype, radial network and network model on the example of lexical units.

The central part of the thesis is the second chapter entitled "Spatial Semantics of Locative Cases", which starts with a general characterisation of the group of locative cases, which constitute the majority of the declension system in the Komi language. Traditionally, Komi linguistics differentiates between internal and external locative cases. This differentiation is based on the paradigmatic meanings of cases. The author also claims that "unlike internal locative cases, external locative cases do not involve in their main meanings relevance to the inner sphere of the landmark (excl. a number of peripheral usages), which expresses their exterior locativeness" (p. 89). The thesis claims that actually the case paradigm of the Permian languages does not feature the opposition between internal and external locative cases like Balto-Finnic languages do. The subchapter "Statistics" discusses the frequency of case forms; yet, the author could have added statistical data on their usage. An important part of this chapter is the description of the cognitive matrix of locative cases, which distinguishes physical, abstract, social, and event space, and the domains of time, state, scale and abstract relations. The author comes to the conclusion that physical space is in the centre of the cognitive matrix, and the other domains are connected and intersect with it.

The author has provided a thorough overview of spatial meanings of cases. While discussing the locative meanings of cases, the author takes into account the semanticgrammatical features of word forms, which is essential in describing case semantics not only in cognitive but also in traditional linguistics. The author introduces as an example the semantic structure of one of the cases (approximative), pointing out its meanings, 
showing the relations between them and presenting them as a network model. Unfortunately, there is no similar network model for the meanings of other cases and their relations. The inner structure of the semantics has been described only as a matrix of cognitive domains. As concerns the other, i.e., non-spatial meanings of cases, they are not described in the thesis proceeding from the cognitive aspect. Also, the meanings mentioned in the thesis have already been treated in research literature (see Guliaev 1961; Nekrasova 2004, etc.). While interpreting the usage of cases, the author provides adequate examples, although these mainly originate from media texts and researches published earlier on.

The doctoral thesis draws on literary language material; yet, in the dialects of the Komi language differences occur in the elements of cases and their usage. The thesis discusses one of the most complex issues in Komi dialectology - the semantics of the case suffix -ьссьӧдз. The author gives his own interpretation of its semantics and claims that "it refers to movement from the point of departure [...] to the point of destination in the vicinity of the viewer" (p. 153). However, material from Udora dialect supports the common description of Komi dialectology (see Sorvacheva \& Beznosikova 1990; Liashev 1975): different word forms are used if the destination is far from the point of departure and the length of distance is emphasised, and in case the point of departure is nearby (see Nekrasova 2012).

The subchapter "Functional Equivalents of Locative Cases" (pp. 175-182) is dedicated to the functional analogues of locative cases and the description of so-called split coding of topological zones. It also includes parts about postpositional constructions and postpositional formants. In the modern Komi language part of localisation types are expressed only by postpositions and are not marked by cases, whereas others can be expressed in parallel by case forms and postpositional constructions. However, the thesis does not discuss all the postpositions competitive with locative cases. I would suggest it would be interesting to find regularities in the distribution of case forms and postpositional constructions.

Under postpositional formants the author discusses units with -ладор-component: adverbs, postpositions, and nouns. Here he dwells on constructions that he conditionally calls postpositional formants (see also Itkin 2002: 167), which have analogues in the Vepsa language. However, constructions with the -ладор-segment considerably differ from postpositions and case forms formally, semantically and syntactically. They can be used with core case markers, or as subjects or direct objects. These features make them similar to relatives. The author could also have compared the semantics of the suffix -ла- and coafix -лань-. The similarity of the semantics of these linguistic units is also supported by Valter Tauli and Ago Künnap, who have claimed that a linguistic unit in the role of coafix has a word derivation function (Tauli 1956: 206-207; Künnap 1983: 52-59).

Nikolay Kuznetsov's doctoral thesis is a complete scientific research on a topical subject. The author demonstrates a thorough knowledge of the basics of cognitive linguistics, understanding of the theoretical problems of the domain, and independent creative thinking in interpreting linguistic material. His work opens a new direction in the studies of the semantics of the grammatical units of the Komi language, making a 
major contribution to Komi and Permic linguistics. Kuznetsov's statements provide a foundation for further studies in the sphere of cognitive linguistics. The practical side of the research is also important, as the material can be used in teaching the Komi language as well as in compiling material for basic and special courses at higher educational institutions.

$$
\begin{array}{r}
\text { Galina Nekrasova (Syktyvkar) } \\
\text { Institute of Language, Literature and History, Komi Scientific Centre, } \\
\text { Uralic Division, Russian Academy of Sciences }
\end{array}
$$

\section{References}

Guliaev, Evgenii 1961. s'-ovye padezhnye suffiksy v komi iazyke (v sravnitel'no-istoricheskom osveshchenii). [Case Suffixes with S'-Element in the Komi Language (in Comparative-Historical Context).] Syktyvkar.

Itkin, Il'ia 2002. Vyrazhenie prostranstvenno-vremennykh otnoshenii v imennykh slovoformakh i problema "poslelozhnykh formantov" (na materiale Korval'skogo dialekta vepsskogo iazyka). [Expressing Spatial-Temporal Relations in Nouns and the Problem of "Postpositional Formants".] V. Plungian (ed.) Issledovaniia po teorii grammatiki. 2: Grammatikalizatsiia prostranstvennykh znachenii $v$ iazykakh mira. Moskva: Russkie slovari, pp. 167-182.

Künnap, Ago 1983. Uurali keelte kohakäänete päritolu probleemist. [On the Problem of the Origin of Locative Cases in Uralic Languages.] Fenno-ugristica 10. Tartu, pp. 52-59.

Liashev, Vladimir 1975. Fonetiko-morfologicheskie osobennosti vymskogo dialekta komi iazyka. [Phonetic-Morphological Peculiarities of Vym Dialect of the Komi Language.] Dissertatsiia na soiskanie uchenoi stepeni kandidata filologicheskikh nauk. Syktyvkar.

Nekrasova, Galina 2004. Vezhlög perym kyv"iasyn: pertas, vezhörtas, artmannog: Velödchan nebög. [Cases in Permian Languages: Form, Meaning, Ways of Formation: Textbook.] Syktyvkar.

Nekrasova, Galina 2012. Semantika padezha: problemy interpretatsii na materiale komi dialektov. [Case Semantics: Problems of Interpretation on the Example of Komi Dialects.] Voprosy kognitivnoi linguistiki, No. 4, pp. 125-129.

Sorvacheva, Valentina \& Beznosikova, Liutsiia 1990. Udorskii dialekt komi iazyka. [Udora Dialect of the Komi Language.] Moskva.

Tauli, Valter 1956. The Origin of Affixes. FUF 32. Helsinki, pp. 170-225. 


\section{ESTONIAN FOLKLORISTS' 8TH WINTER CONFERENCE}

On February 28 and March 1, 2013, the Centre for Landscape and Culture at the Estonian Institute of Humanities, the Centre of Excellence in Cultural Theory and the Academic Folklore Society organised a conference at Tallinn University, under the heading "Folklore in Town and about Town". The conference mainly focused on urban folklore, although some adjacent topics and folklore forms were also discussed, including the Internet, which has recently been used as an efficient source of folklore.

Ehte Järv and Pille Runnel (Estonian National Museum) in their presentation "Schoolchildren's Narratives about Urban Experience - Mapping of a Research Project" dwelt upon the results of a children's essay and drawing contest "Me in Town". On the one hand, the topic of "own places" described at the contest demonstrates children's possibilities to contribute to the usage of urban space; on the other, the places described by them are associated with place lore.

Piret Voolaid (Estonian Literary Museum) in her paper "Add it to Your Status and Learn What People Think about You! Age Group Identity Creation on the Example of Facebook Chain Posts" discussed the content and form of 10-12-year-old girls' chain posts, categorising them by topics (friendship, family and home, school, pets, social events, etc.). The genre similar to chain letters and personal poem collections known from earlier tradition supports the pre-teens' individual self-quests and evolution of social skills and provides the researcher with essential information about the era, environment, culture and young people's understanding of the world.

Eda Kalmre's (Estonian Literary Museum) presentation "Baby Carrots and Salad Rinsing - Commercial Legends and Rumours in Estonian Consumer Society" addressed the origin and evolution of two rumour cycles that recently spread in Estonia. In the autumn of 2009, a hearsay started to be disseminated both in social networks and later on also in the media about supermarkets selling stale salads, from which the old salad dressing had been rinsed out and replaced by fresh one. Although the concrete rumour is of Estonian origin, these stories are universal and are based on people's fears of novel or unfamiliar products, ignoring of cleanliness, domineering and conspiracies of large companies or ethnic groups.

Ell Vahtramäe (Estonian Agricultural Museum) in her presentation "Urban Agriculture on the Internet" discussed how Facebook reflects rural environment. The speaker was of the opinion that agricultural themes were not very popular and the posts mainly concerned general topics.

Jaanika Hunt (Estonian Literary Museum, Tallinn University) in her presentation "Grief Darned on the Body. Memorial Tattoos" spoke about immortalising grief on the body. Earlier on, people in North America and Polynesia believed that tattoos helped them to better orientate in the afterworld. Today, due to the Internet and cultural unification, this body marking method has acquired the function of mourning and commemorating. This kind of body decoration as well as virtual memorial places notify us about changes in mourning traditions.

Stereotypes in a wider and narrower sense were the topic of Elo-Hanna Seljamaa's (University of Tartu) paper "Why Not Study Lasnamäe?" This is a district in Tallinn that for many bears relation to Russians. In the course of her one and a half years of fieldwork, the speaker reached the conclusion that Lasnamäe is both an ordinary urban 
district and also a figure of speech, an epithet and a metaphor, which different actors use to position themselves and others as well as to criticise the current circumstances.

Sille Kapper's (Tallinn University) presentation "Peasants' Dance Tradition in the 21st-Century City" discussed dance as a part of urban folklore, which varies both in primary and secondary contexts. Dance variations result from the dancers' different objectives, incompleteness of verbal dance descriptions, and also the era.

Tiiu Jaago (University of Tartu) in her paper "Town in Older Folksong (Historic Viewpoint)" described different attitudes towards town in runo songs. On the one hand, town in folksongs is associated with positivity: this is where trade and wealth are; on the other hand, town is seen as an immoral place inhabited by promiscuous women.

Aado Lintrop (Estonian Literary Museum) in his paper "Gate Games One Way or Another" talked about Old Town Days in Tallinn and cultural loans. No cultural loan emerges from an empty space; there is always some kind of background that enables to borrow. When initiating a new ritual, we often refer to "old Estonian tradition", which does not necessarily have associations with the former. For instance, in the case of the well-known gate game and the cultural undertaking with the same name, we can talk about conscious context creation.

Mall Hiiemäe (Estonian Literary Museum) in her paper "About the Public Christmas Tree as a Ritual Object" discussed the evolution of Christmas tree tradition. Already as early as in the 16th century, descriptions of Christmas and Shrovetide celebrations at the Blackheads Gild mention a tradition of setting up a conifer in the market square in Riga and Tallinn. The tradition of the Christian Christmas tree is associated with the city of Strasbourg, dating back to 1605 . The custom became established in the 18th century, and in Estonian and German urban families Christmas celebration and giftgiving started in the 19th century. In Estonia, the tradition of setting up a public tree was revived in 1930 .

A peculiar tradition in the Europe of medieval and early modern ages was the topic of Marju Kõivupuu's (Tallinn University) presentation "Magic of Early Modern Ages in Town: Cat as a Sacrificial Animal in Building". Decades ago, a cat mummy dating back to the 18th century was found in a house in Town Hall Square in Tallinn. The speaker explained the background of this weird finding. It was probably a case of protective magic, which had reached Estonia from Germany and was supposed to diminish the number of rats, which devoured grain and spread plague.

Mare Kõiva and Liisa Vesik (Estonian Literary Museum) in their joint presentation "Europe from Estonians' Viewpoint 2. Ethnic Stereotypes as YouTube Clips" dealt with the internet clip "YUROP According to Estonians!", which by its essence is a set of nations' visualised stereotypes.

Inge Annom 


\section{PRESIDENT'S FOLKLORE AWARD AND THE YEAR 2012 AT THE ESTONIAN FOLKLORE ARCHIVES}

The past year at the folklore archives featured diversity and cooperation between the archives and folklore collectors was efficient.

Everyday life at the archives was also multifarious. A new extension with modern depository and studio facilities was completed at the Literary Museum. The folklore archives and hopefully also all our visitors enjoy the light and spaciousness of the renovated research hall, in which undigitised archival manuscripts can be scrutinised in old-fashioned dignified interior. Unfortunately, financing of the museum creates uncertainty among the staff, as it is project-based and inconsistent.

During the past year, the folklore collections were supplemented by materials from different regions of Estonia, in Estonian, Russian, and Votic languages, as well as Võru and Muhu dialects. The materials were collected by volunteers and professional lore collectors, schoolchildren and university students, and also participants of collection actions. In all, over 4000 pages of manuscript material, more than 4200 photographs, over 500 sound and 82 video recordings were added to the collections of the Estonian Folklore Archives (EFA) in 2012.

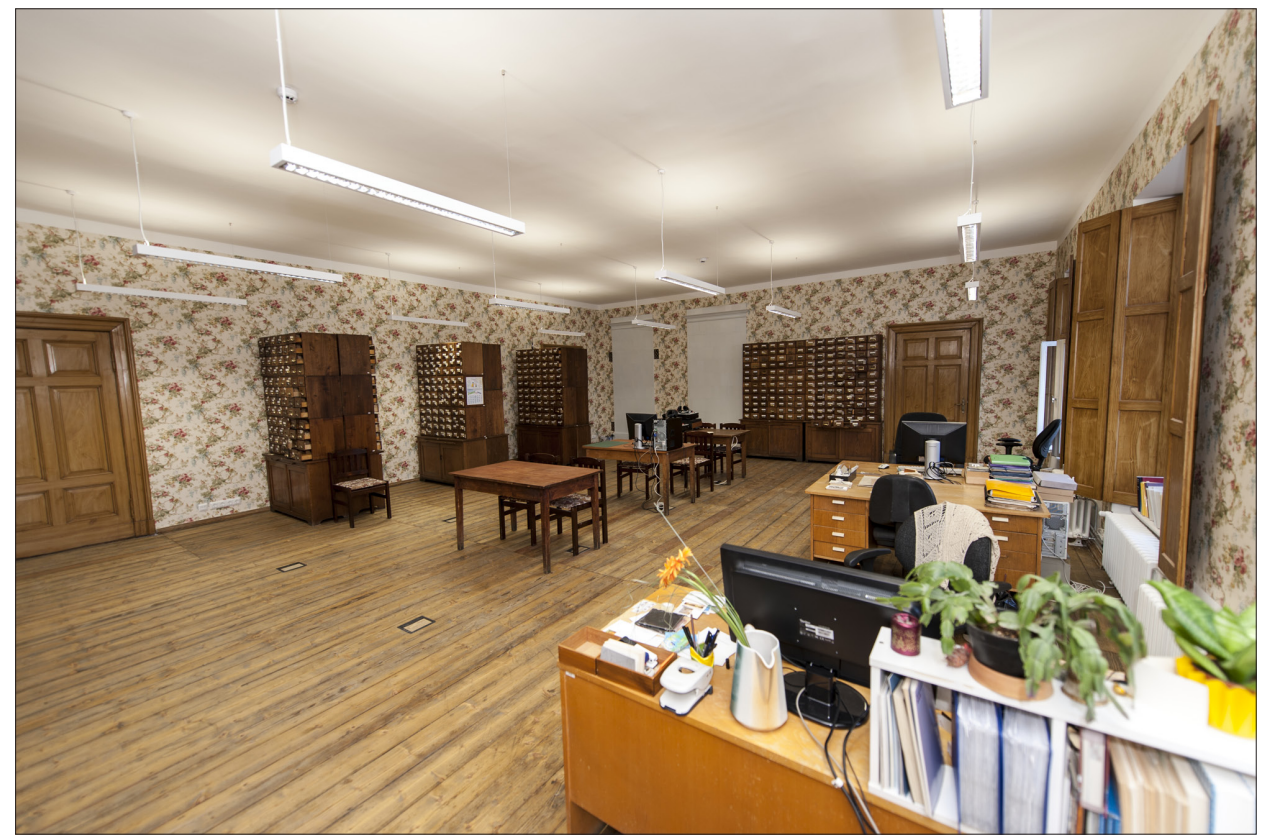

View of the renovated research hall at the EFA on January 21, 2013. Photo by Alar Madisson. 
The President's Award for collecting folklore was given to real enthusiasts, whose primary aim is to record the lore of their native place. This time all the laureates focused on the life of fishermen, as their collection areas were situated by the sea or lakeside.

Rosaali (Roosi) Karjam received an award for long-term and consistent folklore collection. In addition to practising handicrafts, she has written down folklore. She has contributed to the archives since 1992, and the material she has collected amounts to 246 pages. She also earned a collection award in 1994. The materials donated to the museum by Rosaali Karjam are comprehensive and informative, including ethnographic descriptions of handicrafts and fishing on Kihnu Island, as well as folklore about signs of nature, birds, sowing dates, raising of children, food and funeral traditions, calendar customs and different beliefs. She has participated in the collection competitions organised by the folklore archives (incl. the years 2009 and 2012). Also, researchers from different fields have visited Roosi, filmed and recorded her, and been in correspondence with her.

Kaie Humal has continued the work she started in 2008, collecting material about village life as well as biographical lore (particularly, concerning fishermen) in her childhood neighbourhood on the northern shore of Lake Võrtsjärv. By today she has been accepted as local, which has opened more and more doors for her. Her activity has infected several generations of people in the region with a wish to ransack photo albums and their own memories. Reminiscences from the far past come side by side with those from the Soviet period as well as from the more recent life of fishermen. During 2011-2012, she donated to the EFA 50 hours of recorded interviews, 100 pages of notes and documents and 300 photographs, providing a deep insight into the life of one region throughout several decades.

Triin Äärismaa-Unt has collected lore on the opposite side of Estonia - at Jõelähtme, on the northern coast, leading a project concerned with oral heritage in the region. In the summer of 2011, a collection project was launched for the region's youth and culturally minded people, with a focus on place lore, and the material was arranged and handed over to the archives in 2011 and 2012. The recordings included 24 hours of interviews with 272 pages of audiotyped texts, as well as 45 photographs.

Photographer Olev Mihkelmaa donated to the archives 9663 digital photos taken in Kihnu. Jüri Roosmann's calligraphed collection of place lore, reminiscences and legends, as well as Ferdinand Mäe's reminiscences and place lore were mediated by Mari-Ann Remmel.

Twenty-two students from Tartu Kivilinna Gymnasium answered a questionnaire about school lore, which reached the museum through their teacher Pille Pärlin. In addition to schoolchildren's lore, kindergarten lore has also been studied on the initiative of Piret Voolaid. This time, 80 pages of materials from Russian-language kindergarten groups reached the archives.

Students of the University of Tartu under the supervision of Merili Metsvahi and Ergo-Hart Västrik collected lore in Põltsamaa. In the summer of 2012, students of the Estonian Academy of Music and Theatre, supervised by Janika Oras and Ergo-Hart Västrik, carried out fieldwork in Votian and Izhorian villages in Ingermanland. They conducted interviews and participated in several village festivals. 


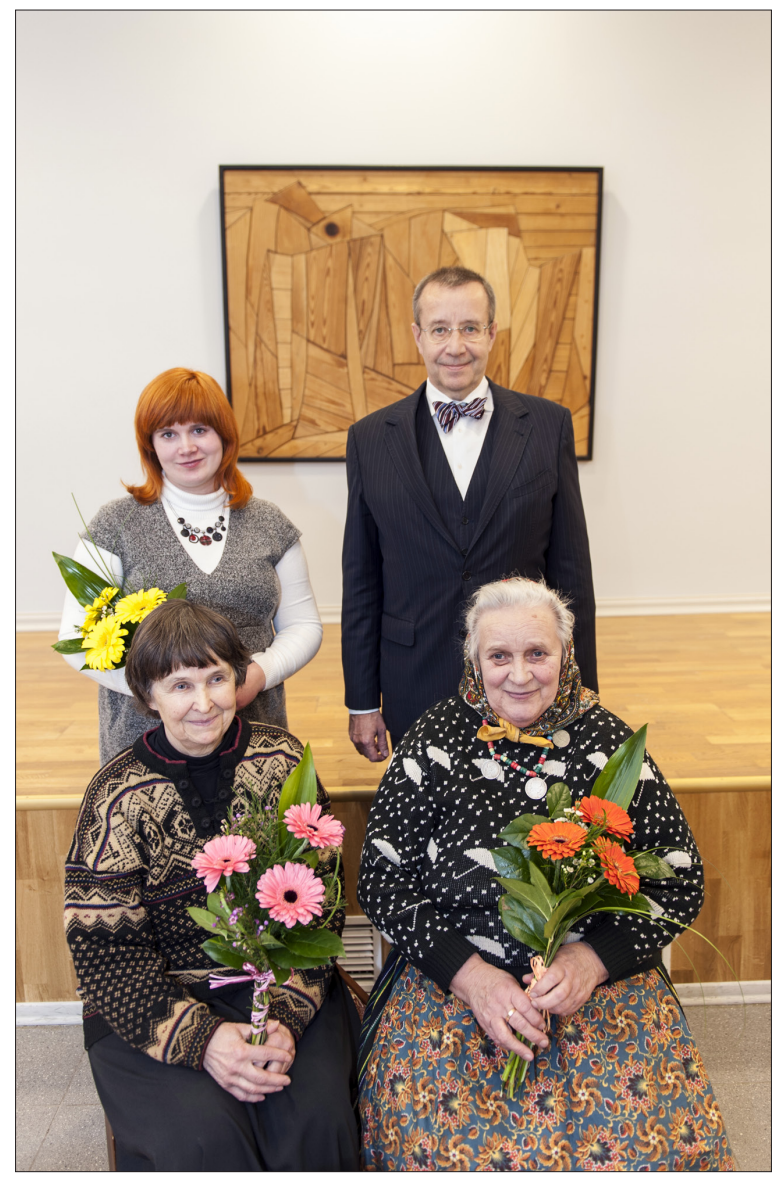

President's Folklore Award ceremony and honouring of EFA 2012 contributors on March 14, 2013. Sitting: Kaie Humal and Rosaali Karjam, standing: Triin Ä̈rismaa-Unt and President Toomas Hendrik Ilves. Photo by Alar Madisson.

Jaan Malin, a long-term contributor to the archives, handed over five song books from Muhu Island, as well as 72 pages of internet folklore; Valter Haamer donated two song books. Maria Parksepp handed over 100 pages of Setomaa lore material. Kadi Sarv and Kaido Kama recorded family reminiscences, Villu Talsi donated recordings of a musician from Miila village, and Kalev Järvela - video recordings with interviews on dance activities, conducted with representatives of the Estonian diaspora in Portland and Seattle.

Story writing contests were organised all over Estonia, which yielded 98 digital pages of contributions in Võro dialect; Kadri Tüür handed over to the archives materials of Muhu dialect contest. 
We are grateful to all our contributors: Atilde Roosiväli, Kalev Järvela, Anni Oraveer, Ahto Raudoja, Kaleph Jõulu, Johannes Kuusk, Tiina Konsen, Age Esula, Fred Puss, Eva Sepping, Maimo Hõbessaar, Aado Lintrop, Pille Vahtmäe, Anu Korb, Andreas Kalkun, Ave Tupits-Goršič, Jüri Metssalu, Valdo Valper, Mari-Ann Remmel, Taive Särg, Eda Kalmre, Helen Kõmmus, Jaanika Hunt, Mari Sarv, Janika Oras, etc.

Last summer, the Pilkaja (Mocker) magazine contacted the archives with a proposition to organise a joint contest of humorous stories. The contest was announced on September 24, the anniversary of the EFA, and it lasted until January 2013. The contest under the heading "Something Funny Happened to Me" was aimed at obtaining original comical stories from real life, which have also been passed on from one person to another, sometimes with smaller changes.

Altogether, 87 people participated in the collection contest, which yielded 791 pages of material. The participants came from different spheres of life and largely described working life and life in general during the Soviet period, revealing Estonians' evaluation of the recent past through the prism of humour. However, there were also funny stories about the present day. Mall Hiiemäe, a member of the jury, stated that on the basis of these stories we can observe how a unique case turns into folklore.

The authors were mainly elderly people; yet, there were also schoolchildren and youngsters among them. In addition to Estonian, the contributions were also in Russian, as well as in Võru dialect, with volumes from dozens of pages to messages sent by mobile phones. The materials included also stories heard from mothers or grandmothers about the preceding generations, which added a temporal dimension.

The past year proved that colourful language, good sense of humour and a skill to notice funny things around you and speak about them are values to be appreciated; especially when we lose the wish to work in the conditions of harsh everyday life and the sense of mission seems not enough to carry on. Hopefully in 2013, which is heritage year, the museum-, archive- and research workers' mission and their need to survive will be recognised. This is necessary for the museum so that we could preserve our cultural heritage for the future generations.

Astrid Tuisk 


\section{TWO HEADS ARE BETTER THAN ONE: PHRASEOLOGY AND PAREMIOLOGY IN DICTIONARIES AND IN EVERYDAY USE}

On April 18 and 19, 2013, an international scientific conference was held in Maribor and Ljubljana (Slovenia) under the heading Two Heads are Better than One: Phraseology and Paremiology in Dictionaries and in Everyday Use. It was organised by the Department of German Studies at the Faculty of Arts of the University of Maribor and the Institute of Slovenian Ethnology, SRC SASA Ljubljana, upon the completion of two research projects supported by the Research Agency of the Republic of Slovenia during the period from 2010 to 2013 . The theme of the event was linked to the research of phraseology and paremiology in the context of both research projects: Phraseology of the German Language: Slovenian-German Comparative and Intercultural Perspectives, which was carried out by the Department of German Studies of the Faculty of Arts of the University of Maribor, and Slovene Proverbs as Cultural Heritage: Classification and Corpus Editing, which is currently being implemented at the Institute of Slovenian Ethnology, SRC SASA in Ljubljana. The conference was held in Slovenian, German and English languages.

The conference discussed the following issues: gathering of paremiological data in the field and methodological issues; editing of archival and collected material, semantic and pragmatic issues and perspectives; phraseology and mutual contact of the Slovenian and German languages (constructive, semantic, pragmatic, and textual issues); paremiology and phraseology in dictionaries: lexicographic, corpus, methodological issues; paremiology and phraseology in the learning and teaching of languages. Topics were discussed from folkloristic and phraseological (linguistic) viewpoints and, as part of the project presentations, computerised classifications were also examined.

The first day of the conference was in Maribor, at the Faculty of Arts. The opening session was dedicated to the presentations of the projects: Vida Jesenšek (Slovenia) talked about the project Phraseology of the German Language: Slovenian-German Comparative and Intercultural Perspectives, and Marjan Krašna (Slovenia) discussed the building of a phraseological database. This was followed by Marija Stanonik, Matej Veider and Simona Janež (Slovenia), who presented the project Slovene Proverbs as Cultural Heritage: Classification and Corpus Editing. They pointed out the problems of compiling a corpus of proverbs on the basis of materials from archives, old manuscripts, grammar books, literature, some field research results, etc. Drago Bokal and his students (Slovenia) had prepared a presentation of computerised proverb textual analysis. The following papers on the first day were more or less from the folkloristic field: Bogdan Dolenc (Slovenia) discussed proverbs in the Bible; Sibil Vilfan Gruntar (Slovenia) showed the influence of the grammar school on adopting Latin proverbs into the Slovenian language. Saša Babič (Slovenia) tried to show the integration of Slovenian proverbs into the international research area, Martina Piko-Rustia (Austria) provided an insight into the materials collected in Carinthia. Alja Lipavic Oštir's (Slovenia) presentation introduced her research into Slovenian schoolchildren's knowledge and usage of proverbs. Peter Grzybek (Austria) discussed macrostructural problems of paremiography. Peter Durčo and Matej Meterc dealt with the equivalency of Slovak and Slovene proverbs, trying to build a typology based on equivalency. 




Prof. Vida Jesenšek (University of Maribor) is introducing the project Phraseology of the German Language: "Slovenian-German Comparative and Intercultural Perspectives”. Photo by Piret Voolaid 2013.

The second day of the conference was in Ljubljana at the Slovenian Research Centre SASA. It started with a folkloristic paper from Barbara Ivančič Kutin (Slovenia) about folklore patterns in the proverb corpus. The day continued with phraseological discussions: Anneli Baran (Estonia) presented phraseological expressions and semantic fixedness investigated within a group of schoolchildren. Melanija Fabčič and Elizabeta Bernjak (Slovenia) talked about (de)onimic components in Slovenian and German phrasemes. Erla Hallsteinsdóttir (Denmark) discussed phraseology in the process of learning German as a foreign language. Teodor Petrič, Saša Jazbec and Brigita Kacjan (Slovenia) discussed phraseological units as a speaking and reception model and tried to provide a didactic concept for learning a foreign language. Željka Matulina (Croatia) and Carmen Melado Blanco (Spain) checked bilingual dictionaries and presented some discussion points related to lexicography and phraseology. Vida Jesenšek and Natalija Ulčnik (Slovenia) exposed problems in editing material for a phraseological-paremiological portal. The closing paper was prepared by Piret Voolaid (Estonia), who presented an academic online database of paremic graffiti; she talked about collecting and presenting some newer paremiological forms. 
Papers form Erika Kržišnik (Vitality of Proverbs Today) and Mateja Jemec Tomazin (Emergence of Metaphorical Terminology and Terminological Guidance) were unfortunately cancelled for medical reasons.

This conference in collaboration with two institutions, embracing two projects (dealing with related themes) was the first one in Slovenia. The main goal of this conference was to offer insights into new developments in selected areas and to create opportunities and directions for further research. The latter is possible only with groundbreaking and cross-sectoral networking and collaboration; for this reason, the search and formation of such possibilities were highlighted. We sincerely hope that there will be more collaboration conferences and more project opportunities to work and research together - in Slovenia and on the international paremiological field.

Saša Babič

\title{
INTERNATIONAL INTERDISCIPLINARY CONFERENCE STILL POSTSOCIALISM? CULTURAL MEMORY AND SOCIAL TRANSFORMATIONS
}

\author{
Kazan, 19-20 April, 2013
}

In the second half of April, a two-day interdisciplinary conference on postsocialism was held in Kazan. The conference under the title, Still Postsocialism? Cultural Memory and Social Transformations, was organised by the Centre for Cultural Studies of Postsocialism and the Institute for Comparative Studies of Modernity, both associated with the Kazan Federal University and European University in St. Petersburg. It must be mentioned that Kazan is a perfect location for such meetings. It is located on the banks of the Volga River, it is the capital of one of the most rebellious Russian regions - the Republic of Tatarstan - and is a wealthy oil industry centre. At the same time, Kazan is a city where Soviet legacy, Russian Orthodox and Tatar Moslem culture along with the blooming and hedonistic inner city form a post-Soviet symbiosis.

The question whether we should and still could speak about postsocialism(s) is not a new one: it was the issue that was discussed at academic conferences at least ten years ago. The fully packed conference with several parallel panels, however, proves that there exists keen academic interest to debate the existence of postsocialism. Unfortunately, the first keynote speeches [Prof. Jan Kubik (Rutgers University, USA) and Prof. Alexander Etkind (University of Cambridge, UK)] were rather a discussion of case studies than addressing general and theoretical issues related to the understanding of postsocialism. The second day keynote speakers [Prof. Caroline Humphrey (University of Cambridge, UK) and Prof. Chris Hann (Max Planck Institute for Social Anthropology, Germany)] 
used concrete case studies (Russian and Hungarian, respectively) to make substantial remarks about the nature of postsocialism. For example, Chris Hann's emphasis on historical continuities is relevant to all regions. He said: "It is not enough to look only at the Socialist era. We should go beyond postsocialism and look at pre-Socialist time for a full picture."

In general, the selection of presentations for the conference was brilliant, covering various spheres and topics. Geographically, the majority of presenters focused on Russia, but some papers discussed also Central Asia, Belarus or Ukraine. Interestingly, in various panels there were several presentations which aimed at merging postcolonial and postsocialist theories. It must be noted that due to different focus points, this is not an easy task, so these papers were theoretically not very sophisticated. Nevertheless, the impressive number of papers demonstrates growing interest in that segment of theorisation.

To name some individual papers, Sanna Turoma's (Aleksanteri Institute, University of Helsinki, Finland) presentation "Grazhdanin Poet / Citizen Poet: Postmodern Poetry for the Postsocialist Masses?" was an interesting analysis of Josif Brodsky and other radical Russian poets. The presentation highlighted the multilayeredness of the socialist society and culture, which also affects their reception in the modern era. Rostislav Kononenko (Higher School of Economics, Moscow, Russia) gave an overview of the question of authenticity in modern Russian folk movement, which seems to suffer from fragmentation just like folk movements in other countries.

Yaroslav Hrytsak (Ukrainian Catholic University, Lviv National University, Ukraine) focused on fluid identities in Ukraine, showing how different interpretations of ethnicity and citizenship exist in Lviv and Donetsk.

The final discussion at the conference became quite heated when some talkers raised the issue whether anthropologists should 'cause a volcano' or be engaged in social and political movements. Chris Hann summed the discussion up by arguing that anthropology as a discipline should be engaged with documentation and should analyse not initiate revolutions; if individuals want to be engaged in politics, they can always join a political party.

In retrospective, the conference was fruitful, demonstrating how strongly the socialist past affects lives, attitudes and cultures in all former socialist countries. I reckon that as long as we speak about the significance of socialism, we should also not hesitate to speak about postsocialism(s).

Aimar Ventsel 


\title{
BOOK REVIEW
}

\section{ABOUT FAIRY TALE GENRE ON THE EXAMPLE OF THE IRISH NARRATIVE TRADITION}

\author{
Vito Carrassi. The Irish Fairy Tale. A Narrative Tradition \\ from the Middle Ages to Yeats and Stephens. Translated \\ by Kevin Wren. Plymouth: John Cabot University Press, \\ 2012. 207 pp.
}

For Vito Carrassi, the author of the book, the main fields of research have involved literary anthropology, narratology and Irish and Italian folklore. The author's treatment of Irish fairy tales was first published in Italian (in 2008) and was translated into English later on.

The heading of the book suggests that it could focus mainly on Irish fairy tales, giving an overview of the changes in the

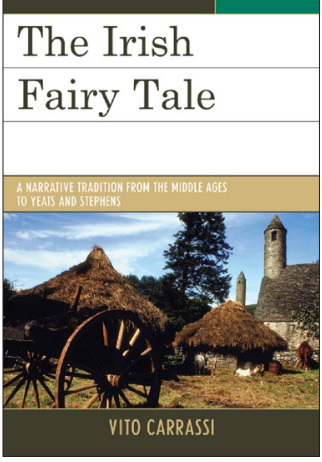
Irish narrative tradition in a temporal perspective. However, the initial impression was misleading: in his treatment Vito Carrassi focuses, above all, on storytelling and narrative tradition in general. Irish folklore is empirical material well known by the author; yet, when reading the book, I had the feeling that it could have been based on the narrative tradition of any European nation. No features intrinsic only to the Irish cultural space or tradition were revealed. Therefore, a more concrete heading would have been more relevant.

The subheading of the book provides a temporal frame for the texts investigated in this research (i.e., from the Middle Ages to the beginning of the 20th century). In connection with the Middle Ages, a brief overview is given about the Christianisation of the Celts, with references to the tradition written down by the monks. Christian culture became well adapted to local culture, which created a favourable basis for the Christianisation of the Celts and merger of Christian features into their oral tradition, thus becoming part of the Irish identity (see, for example, the confrontation between the Anglo-Protestant and the Celtic-Catholic, p. 62). The author's own interest, however, is more focused on the 19th century, when folklore already becomes literary heritage. The author takes a huge leap and steps from the Middle Ages right into the 19th century. Here we could wonder about references to temporal dynamics in the subheading, as the research is not based on this principle.

In the introduction of the book the author provides an overview of the more general principles relating to storytelling, critically dissecting the notions fairy tale, Märchen, Sage, myth, legend, etc., and discussing collectiveness and individuality, tradition and innovativeness.

According to the author, storytelling is a way of interpreting the world; through narrations of past events a storyteller can mediate to the listeners his or her vision or interpretation of these events. Carrassi sees the narrative tradition as a long chain, which extends from today far into the past. Each narrator forms one ring in the chain. They 
use the material from previous narrators and complement the existing stories with new elements, this way providing a new context to the story. So, storytelling involves both collectiveness and individuality, both past and present. Carrassi argues that each independent story is a possible version by itself, and only all of them together form tradition.

The author approaches narrative tradition through written texts. He maintains that instead of reconstructing the original forms of stories, it would be more sensible to explore the tradition of a particular narrative, bearing in mind that it is actually a reconstruction that depends on the material that has persisted in writing, and, therefore, oral tradition can be explored only indirectly (p. 27).

In reference to Walter Ong, several features are elicited, which are inherent in oral storytelling (openness, variability, subjectivity, etc.); if a text is converted into written form, these features disappear and are replaced by the ones inherent in written storytelling (closeness, persistence, objectivity, etc.). Carrassi holds that since the emergence of the written word, we have had to consider the inevitable mutual influence of oral and written culture. Although the author does not refer to Jack Goody, we can detect concurrences in the interpretation of the mutual relations between oral and written cultures. Similarly to Goody, Carrassi sees orality and literacy as two different means of expression, which are employed at a certain moment to describe one and the same culture. While in general, folkloristics has tried to keep the oral and written tradition apart, then Carrassi argues that written text is a version that has been fixated at a certain moment in time, whoever the recorder. The texts written down by a monk, a writer or a folklorist are of the same value. The written text is fixated and does not change any more, whereas the oral version continues to evolve, and therefore it is hard or even impossible to detect the initial version of the story. So, Carrassi understands the oral tradition as an open system prone to changes, whereas written tradition operates as a closed system.

The author has chosen Irish material because in his opinion it reveals at its best the mutual relations between oral storytelling and the written versions reflecting traditional lore. He focuses his analysis on the works of William Butler Yeats, one of the initiators of the Irish Revival Movement. Yeats's (who was generally known as a poet) literary debut consisted in collections of folktales (including fairy tales), which gave an impetus to the abundant use of folk tradition in Irish literature. While Yeats's stories represent oral tradition for the author, then another author, James Stephens's collection clearly represents literature. Yet, Carrassi is convinced that both authors' works represent simultaneously both oral and literary tradition, despite the proportion of oral or literary material in these stories. So, it is not purely oral or purely written tradition but rather their symbiosis. The author argues that both Yeats's and Stephens's fairy tale collections best characterise the interrelations between folklore and literature (see Chapter 3).

By the 19th century, fairy tales had become a privileged genre, which, according to Carrassi, was caused by their ability to simultaneously pass on past tradition and also integrate novel, modern worldview. For me as a reader, the most interesting was Chapter 4, where the author explains the location of the genres myth - legend - history in definite and indefinite fields and the location of the fairy tale in this temporal-spatial dimension. He treats these genres (myth, legend, history) as closed systems. In the transition from myth to legend, from legend to history or from history to myth communal open space emerges, where he places the fairy tale. So, the fairy tale can be viewed as 
a transition form, which carries the characteristics of different genres. This kind of viewpoint is undoubtedly interesting.

Although the proportion of the collective and the individual in narrative tradition has been discussed in several chapters, the author focuses on them in more detail in Chapter 6. Proceeding from the structuralist point of view, Carrassi uses the notions of substructure and metastructure; the former indicates the part in the narrative that is added by the storyteller, whereas the latter represents the part based on tradition.

I would definitely like to point out also Chapter 8, in which the author presents the five phases characterising the evolution of the fairy tale. Here he applies the chronological sequence of the folktale devised by J.W. Foster (see also p. 22). In the preliminary phase, the narrative only establishes itself, and the event/experience predominates here, which is realised as a myth. In the phase following the myth, the narrative is supplemented by personal experience; here informativeness and explanations are essential, and the author links this phase with anecdote genre.

The next phase is constituted by the legend. Here the most important is personal relation to the narrated events, as well as the aspect of the truth, which ensures the survival of the narrative in the community. Phase four is dedicated to the folktale. Here folklore yields more space to literature, and orality to literacy. In this phase, historical truth is replaced by human truth. As the last phase, the author mentions the novella genre, which is absorbed into literary logic, subjected to its rules and created by the author himself. The storyteller's sequence (subject or witness - informant or retailer anecdotalist - storyteller) also proceeds from this kind of narrative development.

In the author's opinion, movement from orality to literacy is progress (not process as in Goody), which culminates in a fairy tale in literary form. Here we could draw a parallel to Jack Zipes's stance, who maintains that the fairy tale has evolved from the folktale and is largely related to literacy. However, it is quite another issue how wellgrounded is the evaluation of oral tradition on the basis of written texts.

In conclusion I would say that the book is really interesting and definitely thoughtprovoking. However, for me the author is not always convincing, despite his spirited and exuberant style. Also, we can argue if such extensive generalisations could be made about the entire narrative tradition on the basis of written texts, but this is up to the readers to decide.

Kärri Toomeos-Orglaan 


\section{OUR AUTHORS}

Piret Voolaid is a senior researcher at the working group of minor forms of folklore at the Department of Folkloristics, Estonian Literary Museum. She received her PhD degree in the field of Estonian and comparative folklore at the University of Tartu in 2011. Her current interests include subgenres of Estonian riddles, proverbs, children's and youth, Internet, and sports lore. Since 2001 she has compiled several academic comprehensive databases of the subgenres of riddles (droodles, conundrums, compound puns, abbreviation riddles, etc.). She has written several studies and compiled popular editions on the basis of database materials.

piret@folklore.ee

Liisi Laineste is a senior researcher at the Department of Folkloristics, Estonian Literary Museum. Since 2000, she has been involved in various grant projects on the subject of ethnic and political humour. Her other fields of interest include post-socialism, Internet folklore (including jokes), humour and aggression, and the history of Estonian ethnic caricatures.

liisi@folklore.ee

Laurent Sébastien Fournier is an assistant professor at the University of Nantes, France. His research focuses on the transformations of traditional rituals, festivals, games and sports in Europe. He has conducted fieldwork in France and Great Britain and has acted as an expert in the field of intangible cultural heritage.

laurent.fournier@univ-nantes.fr

Junwei Yu is Professor at Department of Physical Education, National Taiwan University of Physical Education and Sport. His research interests focus on Taiwan's sporting culture and history, mainly on the historical development and national identities in aboriginal baseball.

chunweiyu@yahoo.com

Sille Kapper is an ethnochoreologist and dance teacher, research fellow at the Department of Choreography of the Institute of Fine Arts, Tallinn University, a dancer in folklore ensemble Leigarid and one of its leaders. She is also a doctoral student at the Estonian Institute of Humanities in the field of studies of cultures, her research focusing on traditional dances in contemporary society.

sille.kapper@gmail.com

Eha Rüütel, PhD in Psychology, an Associate Professor of Clinical Health Psychology, Head of the Department of Applied Creativity and Head of the Arts Therapies Programme, Institute of Fine Arts of Tallinn University. Her main research interests are related to personal and socio-cultural aspects of health and therapeutic use of arts.

eha@tlu.ee 
Iivi Zajedova, $\mathrm{PhD}$ in Political Sciences, Senior Researcher of the Department of Applied Creativity of the Institute of Fine Arts of Tallinn University, a visiting lecturer of the Charles University in the Czech Republic. Her research has been focused on folk hobbies of expatriate Estonians, Baltic studies and identity.

iiviz@yahoo.com

Angela Arraste, MA, is Associate Professor of Estonian Folk Dance at the Department of Choreography of the Institute of Fine Arts, Tallinn University. Her main research interests are related to Estonian folk dance, the narrower line of research being Estonian traditional and author choreographies.

angela@tlu.ee

Sarita Sahay, Adjunct Research Fellow at the School of Political and Social Inquiry, Monash University, Melbourne, Australia, holds a doctoral degree from the Department of Anthropology, Ranchi University (Jharkhand, India). She was associated with Indore School of Social Work (India) and subsequently worked for several years on the changing socio-cultural configuration of some tribes and scheduled caste people of central India at the Centre for Applied Cultural Research, Indore (Madhya Pradesh, India). She is currently also associated with Post Graduate Department of Anthropology, Ranchi University (Jharkhand, India) as a Guest Faculty. Her research interests include tribal studies, women studies, folklore and issues of current concern.

Sarita.sahay@monash.edu

Kalle Voolaid is Research Secretary at the Estonian Sports Museum and editor-in-chief of the journal Sport and Museum published by the museum. He has authored several books on sports history. His current research domain is (Estonian) Olympic history, but he has also studied the image of strongmen in Estonian folk tradition.

kalle@spordimuuseum.ee

Dmitry Belyukov has a doctoral degree in history, and is Dean of the Faculty of Humanities and Socio-Economic Disciplines of Velikiye Luki State Academy of Physical Education and Sports. His research interests include the history of physical education, sport and Olympic movement in the northwest of Russia, and the role of government in the development of physical education and sport.

da197@yandex.ru 
